\title{
Field practices for adapting Mediterranean viticulture to climate change
}

\author{
Author \\ IGNACIO BUESA PUEYO \\ Directors \\ DIEGO SEBASTIANO INTRIGLIOLO MOLINA \\ JUAN RAMÓN CASTEL SÁNCHEZ \\ ALBERTO GARCÍA PRATS
}


Tesis realizada bajo el programa formación de personal investigador del Subprograma FPI-INIA 
La presente tesis doctoral no habría sido posible sin el apoyo de múltiples personas e instituciones.

Quiero agradecer el soporte económico para la realización de esta tesis doctoral al Instituto Nacional de Investigación y Tecnología Agraria y Alimentaria en el marco del proyecto RTA2011-00100-C05-01, titulado “Adecuación agronómica del riego y otras prácticas culturales en Moscatel para vinificación de vinos blancos". Me gustaría agradecer al Centro para el Desarrollo de la Agricultura Sostenible del Instituto Valenciano de Investigaciones Agrarias (IVIA) la facilitación de los medios materiales y personales para su correcto desarrollo. Quiero destacar también el papel formativo que la Universidad Politécnica de Valencia (UVP) me ha dado, así como en el acceso a la bibliografía científica.

Por supuesto, quiero expresar mi más sincero agradecimiento por la dedicación e infinita paciencia que mis directores han invertido en mi formación como investigador. En primer lugar al Dr. Juan Ramón Castel Sánchez, por inculcarme el rigor científico y el espíritu crítico. Al Dr. Alberto García Prats por su siempre buena disposición a ayudarme y asesorarme académicamente. Y muy especialmente al Dr. Diego S. Intrigliolo Molina por el apoyo que me ha brindado, pues ha resultado esencial no solo a nivel científico, sino personal.

Estoy muy agradecido al Servicio de Tecnología del Riego del IVIA, ya que fue durante la beca de formación y especialización que disfruté con D. Pedro Ferrer y D. Luis Bonet cuando se forjó mi interés por la agricultura de regadío.

Además quiero expresar mi gratitud a los muchos compañeros de trabajo de campo, laboratorio y oficina con los que he compartido tantos almuerzos durante estos años. Al Departamento de Riegos del IVIA (Diego Pérez, Felipe Sanz, Antonio Yeves, Javier Castel, Eduardo Badal, Diego Guerra, Carlos Albert, Paco Berbegall, Carlos Ballester, Maa Amparo Martínez-Gimeno, Miquel Jordà, Josep Ortega, Ángela Martínez y Miguel Ángel Jiménez-Bello), así como a los compañeros del CDAS (Dr. Rodolfo Canet, Dr. José Miguel de Paz, Dr. Carlos Ramos y Piedad Romero).

No puedo más que agradecer la acogida que me brindaron los grupos de investigación en los que realicé las estancias pre-doctorales. Al “South Australian R\&D 
Institute" con el Dr. Victor Sadras, el Dr. Marcos Bonada y Martin Moran y a la "Università Cattolica del Sacro Cuore" con el Dr. Stefano Poni, la Dra. Maria Clara Merli, el Dr. Matteo Gatti y Facundo Pirez. Agradecerle también a Giulio Caccavello, de la “Universidad de Nápoles Federico II”, el gratificante y fructífero trabajo conjunto realizado durante su estancia en nuestro grupo del IVIA.

Me gustaría agradecer a mis amigos más próximos y a mi compañera Ana su comprensión y aguante durante la redacción de esta tesis. Y por último, a mi familia, por su apoyo incondicional y por hacerme sentir que están ahí cuando les necesito. Especialmente a mis padres, a quienes además debo agradecer haberme infundido la curiosidad científica.

A todos ellos, por aportar su gotita de agua a esta humilde fuente de conocimiento en la viticultura Mediterránea. 
Als meus pares 


\section{Field practices for adapting Mediterranean viticulture to climate change}

Mediterranean viticulture is being affected by climate change, which threatens wine typicity and, therefore, the whole viticulture sustainability. The main factors expected to affect grapevine cultivation are water scarcity, warm air temperature and the increase in the air carbon dioxide concentration, and impact of these factors will be mainly the: i) advancing of grapevine phenology, thereby decoupling berry technological and phenolic composition and ii) increasing vine water requirements. This $\mathrm{PhD}$ Thesis aimed at evaluating the effects of different field practices to adapt Mediterranean grapevine cultivation to climate change. Three experiments were performed in Valencia (Spain) to assess the effects of 1) regulated deficit irrigation; 2) training systems architecture and; 3) canopy management. The main responses evaluated were vineyard water-use efficiency (WUE) and grape composition. Experiment 1 was undertaken for three seasons in a drip-irrigated, cv. Muscat of Alexandria/161-49C vineyard to define the most sustainable irrigation strategy for white winegrapes in eastern Spain. For this, four treatments were tested: (i) Control, irrigated at $100 \%$ of estimated crop evapotranspiration $\left(\mathrm{ET}_{\mathrm{c}}\right)$ for the entire season; (ii) sustained deficit irrigation (SDI), irrigated at $50 \%$ of Control; (iii) early deficit (ED), where pre-veraison irrigation was withheld, followed by $100 \% \mathrm{ET}_{c}$; and (iv) late deficit (LD), irrigated as in the Control until veraison and thereafter at 25\% ETc until harvest. Results showed that yield in ED and LD was reduced 25 and 15\%, respectively, compared to that of the Control, while yield under SDI did not differ significantly from that of the Control and was similar to that of the ED and LD treatments. All the deficit irrigation treatments had some carry-over effects on vine performance due to a significant decrease in shoot fruitfulness and in cluster mass due to smaller berries. The ED treatment, however, led to a greater reduction in berry growth compared to that of LD. Full irrigation increased pruning mass and leaf area mainly due to larger secondary shoots, and delayed grape ripening as well. In conclusion, the SDI treatment resulted in the greatest WUE, ensuring the high yield potential of the cultivar, providing that a threshold value of the water stress integral of $35 \mathrm{MPa}$ day during the periods from anthesis to veraison and from veraison to harvest was not surpassed. In addition, the SDI strategy favoured an improved grape composition, particularly in terms of grape sugar accumulation. Therefore, sustained deficit irrigation at $50 \%$ of $\mathrm{ET}_{\mathrm{c}}$ should be applied to cv. Muscat of Alexandria where water is scarce or expensive, paying close attention to possible carry-over effects if water withholding has to be continued for longer than three seasons. In experiment 2, the effects of sunlight interception through the vineyard row's orientations on WUE and grape composition were assessed. The trial was 


\section{Abstract}

conducted for three seasons in two Spanish cultivars grafted onto 110R, Bobal and Verdejo, in fully irrigated potted-vines oriented north-south (NS) and east-west (EW). Vine wateruse, namely transpiration, was calculated by means of water balance. Additionally, leaf gas exchange rates were determined on a daily basis. The analysis of pooled data from all the seasons showed that vine transpiration was reduced in the EW row orientation as compared to NS by $13 \%$ in Bobal and by $7 \%$ in Verdejo, corresponding to an $18 \%$ reduction relative to total leaf area in both cultivars. Leaf gas exchange measurements partially confirmed the whole-vine transpiration determinations and showed that the greatest reductions of the EW orientation compared to the NS occurred during the afternoon. Overall, WUE was significantly increased in EW compared to NS by $26 \%$ in Bobal and 19\% in Verdejo with little effects on grape composition. This highlights that the response to the minimizing of the radiation load intercepted by the canopy is cultivar-dependent and that decreasing the radiation load in the Mediterranean vineyards could have positive effects on the whole vine's WUE. Experiment 3 was carried out in two vineyards, one with Bobal/110R and the other with Tempranillo/161-49C. Late leaf removal (LLR) was applied above the cluster zone shortly before veraison, under rainfed and deficit irrigation conditions, for two seasons. The aim was to delay berry-ripening, favouring thermal conditions for pigment accumulation and to couple the anthocyanins and sugars in berries. In addition, the possible effects of LLR on vine water status and vine performance were quantified, as defoliation can be also used as a practice to mitigate the detrimental effects of severe soil water deficit. LLR significantly affected grape-ripening rates under either watering regimes in both cultivars, consequently delaying harvest. Vine water status and leaf photosynthetic rate were improved by LLR. The resultant leaf area-to-fruit ratios of LLR treatments appeared to be more limiting for anthocyanin than for sugars accumulation. As a consequence, LLR negatively-affected wine colour intensity. In addition, in Tempranillo, yield was constrained by LLR due to reductions in cluster and berry mass. In conclusion, a reduction in grape sugar's accumulation rate provoked by LLR did not necessarily result in a more balanced technological and phenolic maturity of the berry. In addition, vineyard WUE was not increased by LLR because, as specifically found for Tempranillo, LLR detrimentally affected vine performance. The effectiveness of the LLR technique seemed to depend on its final impacts on leaf area-to-fruit ratio and vine water status, the cultivar's photosynthetic compensation capacity and the environmental conditions. Therefore, under low vigour vine conditions, severe defoliation might not be advisable for adapting Bobal and Tempranillo to

global warming due to the detrimental effects on red wine quality. On the contrary, the results of deficit irrigation and row orientation experiments provided novel insights on WUE as possible techniques to alleviate vineyard water scarcity. Therefore, the field 
practices studied are effective in adapting Mediterranean viticulture to climate change in terms of water stress. On the other hand, the impacts of the studied techniques in terms of thermal stress alleviation were not fully positive. Hence, further research is needed to determine the possibility of using other field practices, besides LLR, to couple berry sugars and phenolic maturity. 


\section{Técnicas de cultivo para adaptar la viticultura mediterránea al cambio climático}

La viticultura mediterránea se está viendo afectada por el cambio climático, lo que amenaza la tipicidad del vino y, por tanto, la sostenibilidad de la vitivinicultura. Los principales factores que se prevé que afecten al cultivo de la vid son la escasez de agua, los incrementos térmicos y el aumento de la concentración de dióxido de carbono en el aire, lo que influirá en la vid: i) adelantando su fenología, disociando así la maduración tecnológica y fenólica de la uva y ii) incrementando las necesidades hídricas del viñedo. Éste trabajo pretende evaluar los efectos de diferentes técnicas de cultivo para la adaptación de la viticultura mediterránea al cambio climático. Se realizaron tres experimentos en Valencia (España) estudiando los efectos de: 1) el riego deficitario controlado; 2) la arquitectura de los sistemas de conducción y 3) el manejo del dosel vegetal. Las principales respuestas evaluadas fueron la eficiencia en el uso del agua de los viñedos (EUA) y la composición de la uva. El experimento 1 se llevó a cabo durante tres campañas en un viñedo de Moscatel de Alejandría/161-49C regado por goteo con el objetivo de definir la estrategia de riego más sostenible para uva blanca en el levante español. Para ello, se ensayaron cuatro tratamientos: (i) Testigo, regado al 100\% de la evapotranspiración del cultivo $\left(\mathrm{ET}_{\mathrm{c}}\right.$ ) durante toda la campaña; (ii) riego deficitario sostenido (SDI), regado al 50\% del Testigo; (iii) déficit temprano (ED), donde se restringió el riego antes del envero, seguido de un $100 \%$ de $\mathrm{ET}_{\mathrm{c}} ; \mathrm{y}$ (iv) déficit tardío (LD), regado como el Testigo hasta el envero y posteriormente al $25 \%$ de la $\mathrm{ET}_{\mathrm{c}}$ hasta la vendimia. La producción en el ED y el LD se redujo en un 25 y 15\% respectivamente en comparación a la del Testigo, mientras que la producción del SDI no difirió significativamente del Testigo ni de los tratamientos de ED y LD. Todos los tratamientos con riego deficitario mostraron efectos acumulativos en la productividad de las cepas como consecuencia de la reducción del número de racimos por sarmiento y del tamaño del racimo debido al menor tamaño de la baya. No obstante, el tratamiento ED conllevó una mayor reducción del crecimiento de la baya comparado al LD. El riego del Testigo incrementó el peso de poda y el área foliar, principalmente debido al mayor tamaño de los brotes secundarios, y además retrasó la maduración de la uva. En conclusión, el tratamiento SDI incrementó la EUA, garantizando el elevado potencial productivo de la variedad Moscatel, siempre y cuando no se sobrepasara el valor umbral de la integral de estrés hídrico de 35 MPa día durante los periodos desde la floración al envero y desde el envero a la cosecha. Además, la estrategia SDI favoreció a la composición de la uva, particularmente en cuanto a la acumulación de azúcares. Por lo tanto, en condiciones de escasez de recursos hídricos o de elevados precios del agua de riego, la variedad Moscatel 
de Alejandría puede regarse deficitariamente al 50\% de $\mathrm{ET}_{\mathrm{c}}$ durante toda la campaña, prestando mucha atención a los posibles efectos acumulativos si la restricción tuviera que alargarse durante más de tres años. En el experimento 2 se estudiaron los efectos de la intercepción solar en función de la orientación de las filas del viñedo sobre la EUA y la composición de la uva. El ensayo se realizó durante tres campañas en dos variedades españolas injertadas sobre 110R, Bobal y Verdejo, plantadas en maceta y sin estrés hídrico con las filas de espalderas orientadas norte-sur (NS) o este-oeste (EO). El uso de agua de las cepas, concretamente su transpiración, se determinó mediante balance hídrico. Adicionalmente, se midieron las tasas de intercambio gaseoso a nivel de hoja. El análisis de los datos de todas las campañas mostró que la transpiración se redujo en un 13\% en Bobal y en un 7\% en Verdejo en la orientación de las filas EO en comparación con la NS, lo que en ambas variedades correspondió a una reducción en la transpiración relativa al área foliar total del 18\%. Las medidas de intercambio gaseoso a nivel de hoja confirmaron parcialmente las determinaciones de la transpiración de la planta entera y mostraron que las mayores reducciones de la orientación EO en comparación a la NS ocurrieron durante la tarde. En términos generales, la EUA se incrementó en un 26\% en Bobal y $19 \%$ en Verdejo comparando la orientación EO con la NS, con leves efectos en la composición de la uva. Esto pone de manifiesto que la respuesta a la minimización de la radiación interceptada por el dosel vegetal es dependiente de la variedad y que reducir la carga de radiación en viñedos de clima mediterráneo podría tener efectos positivos en la EUA de la vid. El experimento 3 se llevó a cabo en dos viñedos, uno de Bobal/110R y el otro de Tempranillo/161-49C. Durante dos años, en condiciones de secano y de riego deficitario, se aplicó un deshojado tardío (LLR) por encima de la zona del racimo poco antes del envero. El objetivo era retrasar la maduración de la uva, favoreciendo así las condiciones térmicas para su pigmentación y la sincronización de la acumulación de antocianos y azúcares en la baya. Además se cuantificaron los posibles efectos del LLR sobre el estado hídrico y el rendimiento de la vid, ya que la defoliación puede utilizarse como práctica para mitigar los efectos perjudiciales del déficit hídrico severo. El LLR afectó significativamente las tasas de maduración de la uva bajo ambos regímenes de riego en cualquiera de las dos variedades, y por tanto, retrasó la fecha de vendimia. El LLR mejoró el estado hídrico del viñedo y la tasa de fotosíntesis a nivel de hoja. La relación área foliar/producción de los tratamientos de LLR resultó ser más limitante para la síntesis de antocianos que para la acumulación de azúcares. En consecuencia, la intensidad de color del vino se vio afectada negativamente por el LLR. Además, la producción del Tempranillo se redujo por efecto del LLR debido a la reducción del tamaño de baya y del racimo. En conclusión, la reducción en la tasa de acumulación de azúcares en la uva provocada por el LLR no resultó necesariamente en una madurez 
tecnológica y fenólica más equilibrada. Por otra parte, el LLR no incrementó la EUA del viñedo, ya que, como se observó expresamente en Tempranillo, el LLR redujo la producción. La efectividad de la técnica de LLR parece depender de sus efectos sobre la relación área foliar/producción y el estado hídrico de la vid, la capacidad fotosintética compensatoria de la variedad y de las condiciones ambientales. Por consiguiente, en viñedos de baja vigorosidad, una defoliación severa puede no ser aconsejable para adaptar las variedades Bobal y Tempranillo al calentamiento global debido a los efectos perjudiciales sobre la calidad del vino tinto. Por el contrario, los resultados de los experimentos de riego deficitario y de orientación de las filas de espaldera proporcionan nuevos hallazgos en la EUA como posibles técnicas para paliar la escasez de agua en el viñedo. Por lo tanto, las técnicas de campo estudiadas resultan eficaces en adaptar la viticultura mediterránea al cambio climático en cuanto al estrés hídrico. Sin embargo, sus efectos en términos de mitigación del estrés térmico no fueron del todo positivos. Por tanto, es necesario realizar más investigaciones para determinar la viabilidad de emplear otras prácticas de campo, distintas al LLR, para equilibrar la madurez glúcida y fenólica de la uva. 


\section{Tècniques de cultiu per adaptar la viticultura mediterrània al canvi climàtic}

La viticultura mediterrània s'està veient afectada pel canvi climàtic, el que amenaça la tipicitat del vi i, per tant, la sostenibilitat de la vitivinicultura. Els principals factors que es preveu que afecten el cultiu de la vinya són l'escassetat d'aigua, els increments tèrmics i l'augment de la concentració de diòxid de carboni en l'aire, el que influirà en la vinya: i) avançant la seva fenologia, dissociant així la maduració tecnològica i fenòlica del raïm i ii) incrementant les necessitats hídriques de la vinya. Aquest treball pretén avaluar els efectes de diferents tècniques de cultiu per a l'adaptació de la viticultura mediterrània al canvi climàtic. Es van realitzar tres experiments a València (Espanya) estudiant els efectes de: 1) el reg deficitari controlat; 2) l'arquitectura dels sistemes de conducció i 3) el maneig del dosser vegetal. Les principals respostes avaluades van ser l'eficiència en l'ús de l'aigua de la vinya (EUA) i la composició del raïm. L'experiment 1 es va dur a terme durant tres campanyes en una vinya de Moscatell d'Alexandria/161-49C regat per goteig amb l'objectiu de definir l'estratègia de reg més sostenible per al raïm blanc en el llevant espanyol. A tal efecte, es van assajar quatre tractaments: (i) Control, regat al 100\% de l'evapotranspiració del cultiu (ETc) durant tota la campanya; (ii) reg deficitari sostingut (SDI), regat al 50\% del Contol; (iii) dèficit primerenc (ED), on es va restringir el reg abans del verol, seguit d'un $100 \%$ d'ETc; i (iv) dèficit tardà (LD), regat com el Control fins al verol i posteriorment al $25 \%$ de l'ETc fins a la verema. La producció en l'ED i el LD es va reduir en un 25 i 15\% respectivament en comparació a la del Control, mentre que la producció del SDI no va diferir significativament del Control ni dels tractaments d'ED i LD. Tots els tractaments amb reg deficitari mostraren efectes acumulatius en la productivitat dels ceps, com a conseqüència de la reducció del nombre de raïms per sarment i del tamany del pomell a causa de la menor grandària de la baia. No obstant això, el tractament ED va comportar una major reducció del creixement de la baia comparat amb el LD. El reg del Control va incrementar el pes de poda i l'àrea foliar, principalment a causa de la major grandària dels brots secundaris, i a més va retardar la maduració del raïm. En conclusió, el tractament SDI va incrementar l'EUA, garantint l'elevat potencial productiu de la varietat Moscatell, sempre que no es sobrepassara el valor llindar de la integral d'estrés hídric de 35 MPa dia durant els períodes des de la floració al verol i des del verol a la collita. A més, l'estratègia SDI va afectar positivament la composició del raïm, particularment pel que fa a l'acumulació de sucres. Per tant, en condicions d'escassetat de recursos hídrics o d'elevats preus de l'aigua de reg, la varietat Moscatell d'Alexandria pot regar-se deficitàriament al 50\% d'ETc durant tota la campanya, prestant molta atenció als possibles efectes acumulatius si la restricció es donara durant més de tres anys. En l'experiment 2 es van estudiar els efectes de la intercepció solar 
en funció de l'orientació de les files de la vinya sobre l'EUA i la composició del raïm. L'assaig es realitzà durant tres campanyes en dos varietats espanyoles empeltades sobre 110R, Boval i Verdejo, plantades en test i sense estrés hídric, amb les files d'espatleres orientades nord-sud (NS) o est-oest (EO). L'ús d'aigua dels ceps, concretament la seua transpiració, es va determinar mitjançant balanç hídric. Addicionalment, es mesuraren les taxes d'intercanvi gasós a nivell de fulla. L'anàlisi de les dades de totes les campanyes va mostrar que la transpiració es va reduir en un 13\% en Boval i en un 7\% en Verdejo en l'orientació de les files EO en comparació amb la NS, el que en les dues varietats va correspondre amb una reducció en la transpiració relativa a l'àrea foliar total del 18\%. Les mesures d'intercanvi gasós a nivell de fulla van confirmar parcialment les determinacions de la transpiració de la planta sencera i van mostrar que les majors reduccions de l'orientació EO en comparació a la NS van ocórrer durant la vesprada. En termes generals, l'EUA es va incrementar en un 26\% en Boval i 19\% en Verdejo comparant l'orientació EO amb la NS, amb lleus efectes en la composició del raïm. Açò posa de manifest que la resposta a la minimització de la radiació interceptada pel dosser vegetal és dependent de la varietat i que reduir la càrrega de radiació en ceps de clima mediterrani podria tindre efectes positius en I'EUA de la vinya. L'experiment 3 es va dur a terme en dos vinyes, una de Boval/110R i l'altra de Ull de llebre/161-49C. Durant dos anys, en condicions de secà i de reg deficitari, s'aplicà un desfullat tardà (LLR) per damunt de la zona del raïm poc abans del verol. L'objectiu era retardar la maduració del raïm, afavorint així les condicions tèrmiques per a la seua pigmentació i la sincronització de l'acumulació d'antocians i sucres en la baia. A més es van quantificar els possibles efectes del LLR sobre l'estat hídric i el rendiment de la vinya, ja que la defoliació pot utilitzar-se com a pràctica per a mitigar els efectes perjudicials del dèficit hídric sever. El LLR va afectar significativament les taxes de maduració del raïm en els dos règims de reg en qualsevol de les dues varietats, i per tant, va retardar la data de verema. El LLR va millorar l'estat hídric de la vinya i la taxa de fotosíntesi a nivell de fulla. La relació àrea foliar/producció dels tractaments de LLR va resultar més limitant per a la síntesi d'antocians que per a l'acumulació de sucres. En conseqüència, la intensitat de color del vi es va veure afectada negativament pel LLR. A més, la producció de l'Ull de llebre es va reduir per efecte del LLR a causa de la reducció de la grandària de baia i del pomell. En conclusió, la reducció en la taxa d'acumulació de sucres en el raïm provocada pel LLR no va resultar necessàriament en una maduresa tecnològica i fenòlica més equilibrada. D’altra banda, el LLR no va incrementar l'EUA de la vinya, ja que, com es va observar expressament en Ull de llebre, el LLR va reduir la producció. L'efectivitat de la tècnica de LLR pareix dependre dels seus efectes sobre la relació àrea foliar/producció i l'estat hídric de la vinya, de la capacitat fotosintètica compensatòria de la varietat i de les condicions ambientals. Per consegüent, 
en vinyes de baixa vigorositat, una defoliació severa pot no ser recomanable per a adaptar les varietats Boval i Ull de llebre al calfament global, tenint en compte els efectes perjudicials sobre la qualitat del vi negre. Per contra, els resultats dels experiments de reg deficitari i d'orientació de les files d'espatlera proporcionen noves troballes en l'EUA com a possibles tècniques per pal-liar l'escassetat d'aigua a la vinya. Per tant, les tècniques de camp estudiades resulten eficaces a adaptar la viticultura mediterrània al canvi climàtic pel que fa a l'estrés hídric. No obstant, els seus efectes en termes de mitigació de l'estrés tèrmic no van ser del tot positius. Per tant, cal realitzar més investigacions per a determinar la viabilitat d'emprar altres pràctiques de camp, distintes al LLR, per a equilibrar la maduresa glúcida i fenòlica del raïm. 


\section{General index}

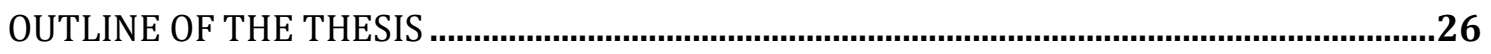

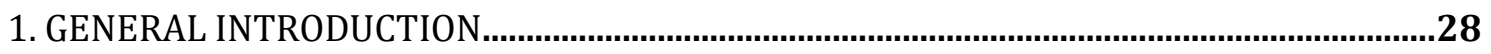

1.1. VITIS VINIFERA IN MEDITERRANEAN-LIKE CLIMATIC REGIONS ....................................................29

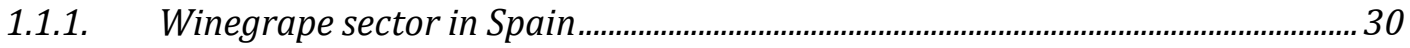

1.1.2. Vine water relations............................................................................................... 32

1.1.3. Grapevine training systems and canopy management …........................................ 34

1.2. CLIMATE CHANGE IMPACTS ON MEDITERRANEAN-LIKE VITICULTURE......................................39

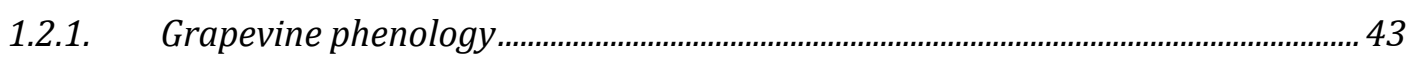

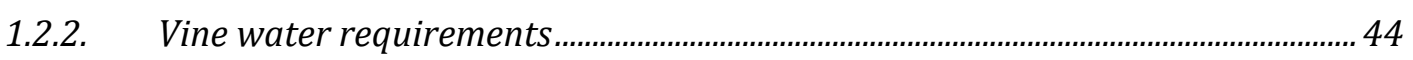

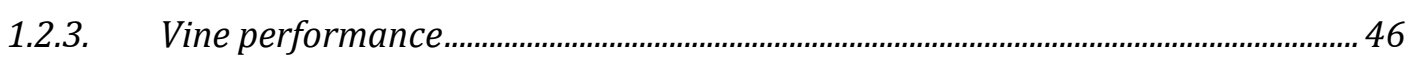

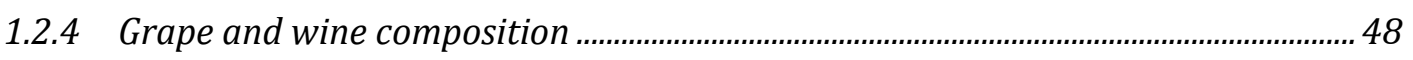

1.3. VITICULTURAL ADAPTATION TECHNIQUES TO CLIMATE CHANGE ..............................................51

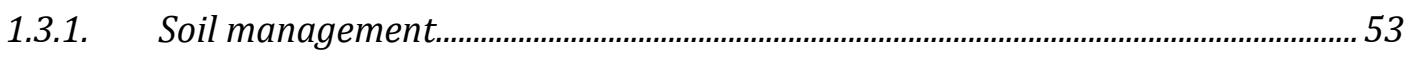

1.3.2. Water supply ….......................................................................................................... 56

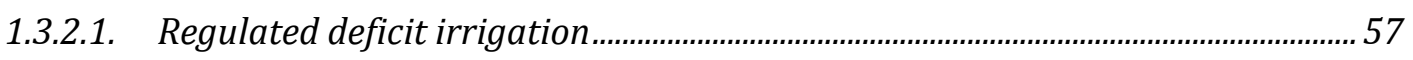

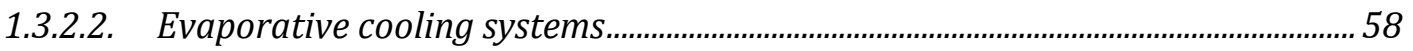

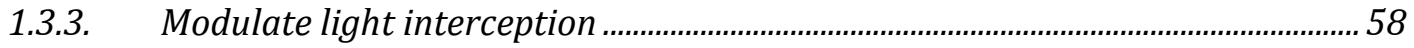

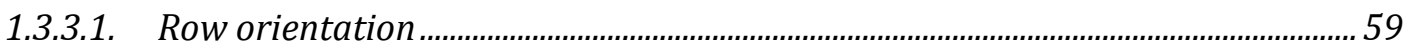

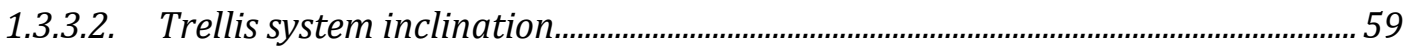

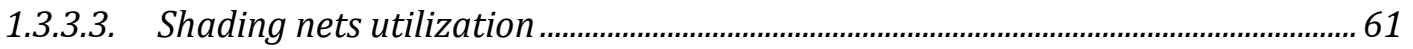

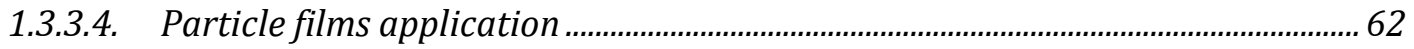

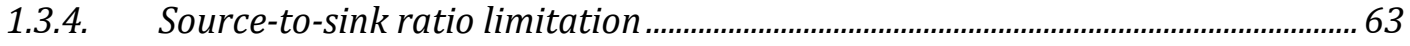

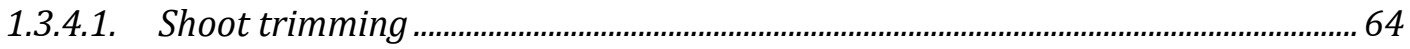

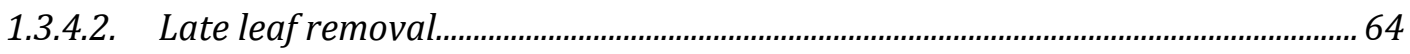

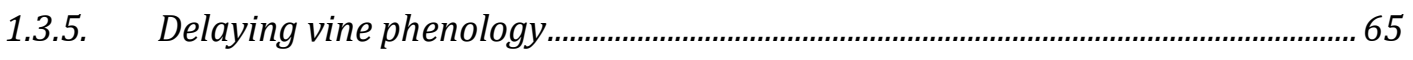

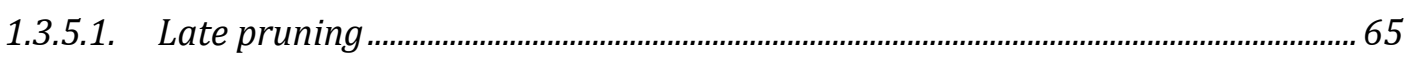

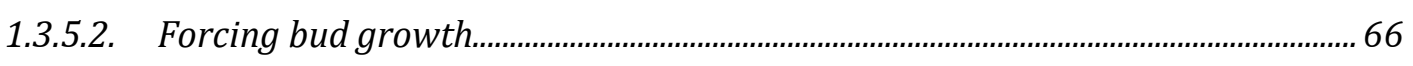

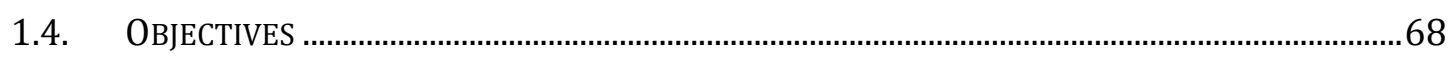

2. DEFICIT IRRIGATION FOR IMPROVING WATER-USE EFFICIENCY AND GRAPE COMPOSITION IN VITIS VINIFERA L. CV. MUSCAT OF ALEXANDRIA.....................................70

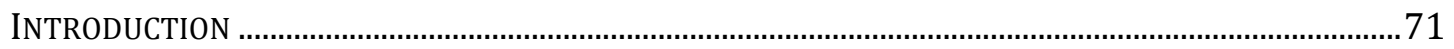

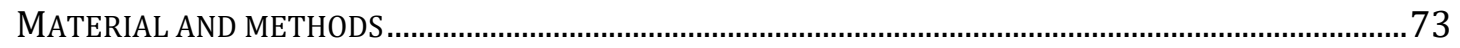

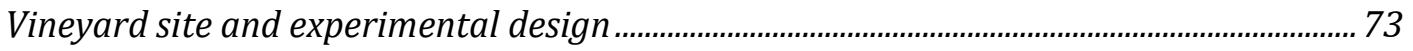

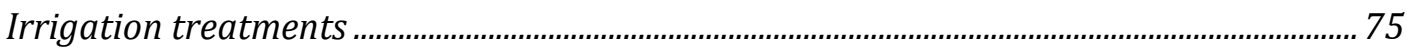


Water relations

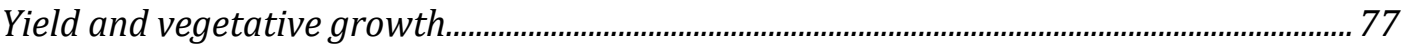

Grape composition ……............................................................................................................. 78

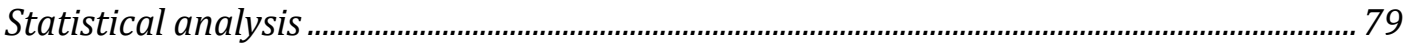

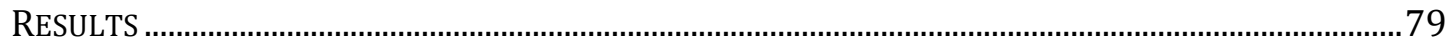

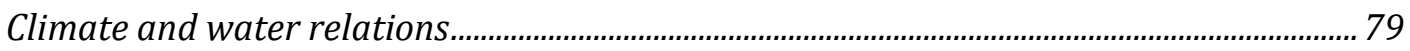

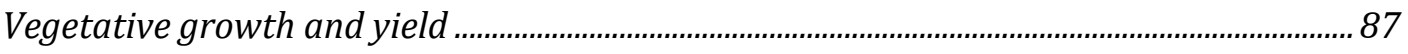

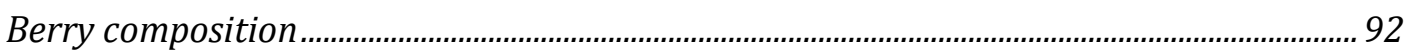

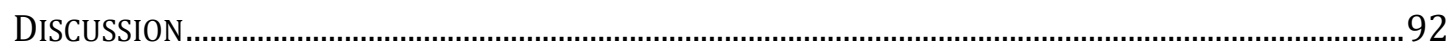

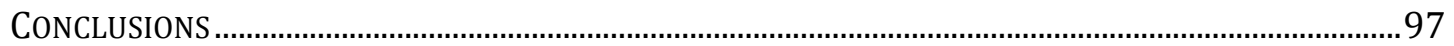

3. VINEYARD ROW'S ORIENTATION EFFECTS ON WATER-USE EFFICIENCY AND GRAPE COMPOSITION OF POTTED GRAPEVINES CVS. VERDEJO AND BOBAL ...................................99

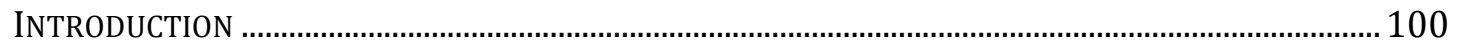

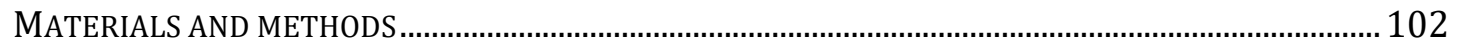

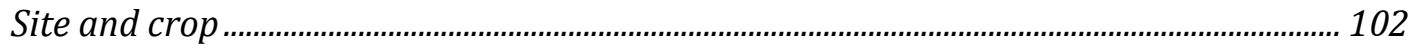

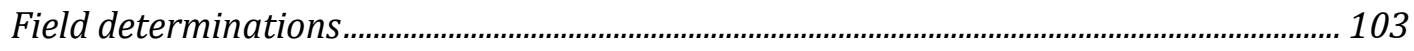

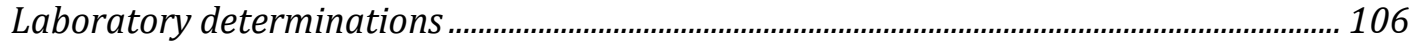

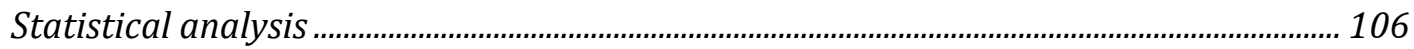

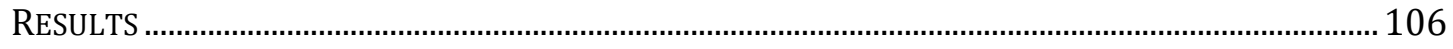

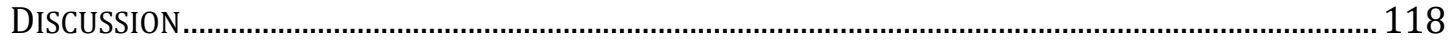

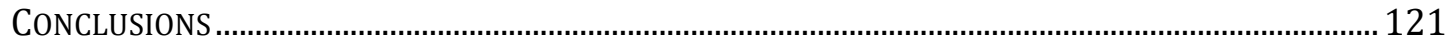

4. DELAYING BERRY RIPENING BY LATE LEAF REMOVAL FOR AMELIORATING GRAPE AND WINE COMPOSITION OF CVS. BOBAL AND TEMPRANILLO ........................................123

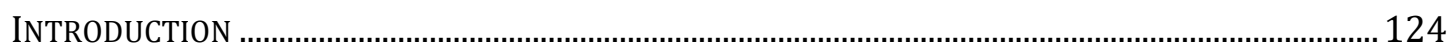

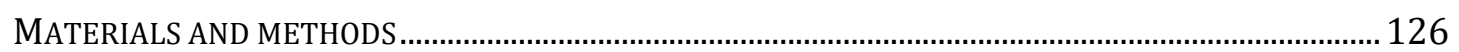

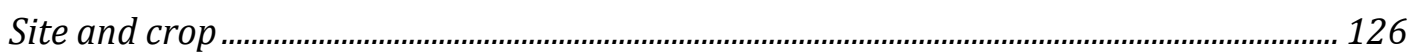

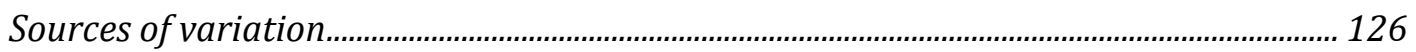

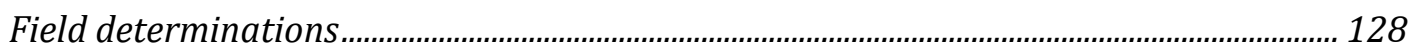

Grape and wine composition...................................................................................................... 129

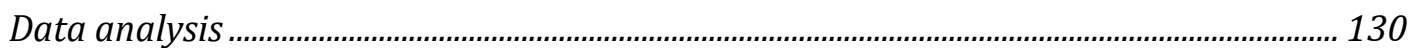

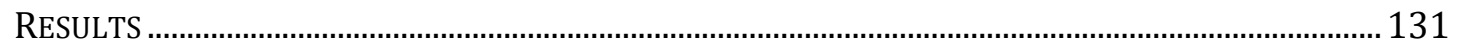

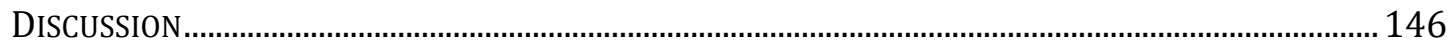

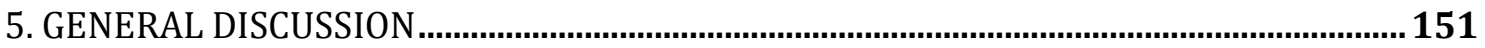

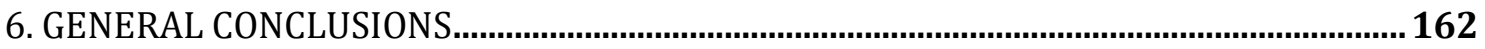

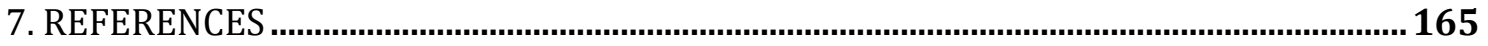




\section{Table index}

Table 1. Set of viticultural adaptation techniques to climate change and its possible effects

Table 2. Values of climate variables and irrigation amounts from budburst until harvest for each treatment during the 3 years of the experiment in Vilamarxant (Valencia), Spain......78

Table 3. Values of the water stress integral $\left(\mathrm{S}_{\Psi}\right)$ during the period from anthesis to veraison and from veraison to harvest during the 3 years of the experiment, and the seasonal average for Muscat of Alexandria wine grapes subjected to different irrigation strategies

Table 4. Average values of vegetative growth over the 3 years of the experiment for Muscat of Alexandria wine grapes subjected to different irrigation strategies

Table 5. Average values of yield components over 3 years for Muscat of Alexandria wine grapes subjected to different irrigation strategies

Table 6. Average values for must composition attributes at harvest for Muscat of Alexandria grapes subjected to different irrigation treatments during the 3 years of the experiment .88

Table 7. Vegetative development, leaf area-to-yield ratio, water-use, water-use relative to leaf area and water-use efficiency in north-south and east-west vineyard row's orientation in Bobal and Verdejo potted vines during three seasons 107

Table 8. Leaf gas exchange parameters of Bobal and Verdejo potted-vines orientated in rows towards north-south (NS) or east-west (EW) pooled across three seasons

Table 9. Yield components of potted-vines in rows oriented north-south (NS) and east-west (EW) in Bobal and Verdejo grapevines during three seasons.

Table 10. Seasonal and annual average values of berry composition parameters of Bobal and Verdejo winegrapes subjected to different vineyard row's orientation.

Table 11. Total amount of water received (rain plus irrigation) from April $1^{\text {st }}$ to September $30^{\text {th }}$ and total leaf area after LLR application in Bobal and Tempranillo vines exposed to the following four treatments: IU, irrigated-undefoliated; ID, irrigated-defoliated; RU, rainfedundefoliated; RD, rainfed-defoliated. 
Index

Table 12. Values of yield components and vegetative growth in the trial established during 2014 and 2014 on Vitis vinifera L., cv. Bobal and Tempranillo trials at Requena, Valencia, Spain 133

Table 13. The harvest date and must technological composition attributes at harvest of Vitis vinifera L., cv. Bobal and Tempranillo trials in the two seasons under different watering regime (WR) and canopy management (CM) in Requena, Valencia, Spain. 136

Table 14. Berry phenolic composition attributes at harvest of Vitis vinifera L., cv. Bobal and Tempranillo trials in the two seasons under different watering regime (WR) and canopy management (CM) in Requena, Valencia, Spain

Table 15. Seasonal values of wine composition parameters made of Bobal and Tempranillo winegrapes subjected to different watering regime and canopy management factors in Requena, Valencia, Spain 


\section{Table of figures}

Figure 1. Vase system in an old vine combining spur and cane pruning (Requena, Spain)

Figure 2. Parral training system combining spur and cane pruning (Mendoza, Argentina) .34

Figure 3. Gable trellis system in a vigorous vineyard (Bolzano, Italy)..... 35

Figure 4. Annual-global average (black) of combined land (brown) and ocean surface (blue) temperature anomalies relative to the average over the period 1986 to 2005 .

Figure 5. Global average surface temperature change from 2006 to 2100 as determined by multi-model simulations (IPCC 2014). Time series of projections and a measure of uncertainty (shading) are shown for different scenarios......

Figure 6. Mean projections for the 2081-2100 period under for different scenarios for the percentage of annual mean surface.

Figure 7. Mean projections for the 2081-2100 period under for different scenarios for the percentage of change in annual mean precipitation.

Figure 8. Pruned vine-wood mulch applied on a Bobal vineyard soil (Requena, Spain).....53

Figure 9. Leaning canopy of potted Verdejo vines (Moncada, Spain)..... . .58

Figure 10. Shading nets over a Macabeo vineyard (Requena, Spain). . .59

Figure 11. Late pruned Tempranillo vines (left) and winter pruned (right) Requena, Spain)

Figure 12. Double pruning to force bud growth in Tempranillo vines (Requena, Spain)....65

Figure 13. A general view of the Muscat of Alexandria vineyard in 2014. The photograph was taken just after shoot thinning application.....

Figure 14. Appearance of the east side of a Muscat of Alexandria vine near harvest in 2013 . .76 
Index

Figure 15. Effect of sustained deficit ( $\square$ ), early deficit (ED) $(\nabla)$ and late deficit (LD) ( $\mathbf{\Delta}$ ) irrigation treatments on the seasonal evolution of midday stem water potential ( $\Psi_{\text {stem }}$ ) of Muscat of Alexandria grapevines in (a) 2012, (b) 2013 and (c) 2014 compared to that of the Control $(\bullet)$. Data are averages and standard errors of 16 leaves per treatment and date. Veraison (mean \pm SD) $(\bullet)$, the start/end of irrigation $(\downarrow)$ and rainfall $(\square)$ are indicated.

Figure 16. Effect of sustained deficit $(\square)$, early deficit $(\square)$ and late deficit $(\square)$ irrigation treatments on the shoot fruitfulness (clusters per shoot) of Muscat of Alexandria grapevines for the seasons 2012, 2013 and 2014 compared to that of the Control (ש), and additionally, the carry-over effect in 2015

Figure 17. Effect of sustained deficit $(\bullet)$, early deficit $(\circ)$ and late deficit $(\boldsymbol{\nabla})$ irrigation treatments on the seasonal evolution of TSS in Muscat of Alexandria grapes for seasons (a) 2012, (b) 2013 and (c) 2014 compared to that of the Control ( $\Delta$ ).

Figure 18. Potted drip-irrigated vines covered with silver plastic in a vertical shoots positioned trellis system orientated NS in the first season (2014). Canopy size was approximately $2 \mathrm{~m} \times 2 \mathrm{~m}$

Figure 19. Emptying and measuring the water volume of the underground drainage collector system, which included a reservoir per each five vines during seasons 2015 and 2016

Figure 20. Seasonal patterns of the daily maximum air temperature $(\bullet)$, mean air temperature (O) and incoming solar radiation ( $\boldsymbol{\nabla})$ in Moncada, Valencia, Spain. The day of year (DOY) follows a continuous annual-time scale from $1^{\text {st }}$ of April to $15^{\text {th }}$ of September 105

Figure 21. Bobal phenology in north-south (NS; •) and east-west (EW; •) vineyard row's orientation during 2016. The percentage of coloured berries is depicted for the 2014 season.

Figure 22. Shoot length (principal + secondary) in Bobal north-south (NS; •) and east-west $(\mathrm{EW} ; \bullet)$ and of Verdejo in north-south (NS; $\nabla)$ and east-west (EW; $\boldsymbol{\nabla})$ vineyard row's orientation of Verdejo and Bobal during 2016

Figure 23. Vine water status evolution during the 2016 season in north-south (NS) and east-west (EW) vineyard row's orientation in Bobal [(a)] and Verdejo [(b)] cultivars. Data 
are averages and standard errors of 2 leafs per experimental unit $(n=8)$ for the predawn leaf water potential $(\nabla, \nabla)$ and midday stem water potential $(\bullet, \bullet)$

Figure 24. Seasonal transpiration of Bobal (left) and Verdejo (right) potted vines in northsouth (NS; •) and east-west (EW; •) vineyard row's orientation in 2014 [(a) and (b)], 2015 $[(c)$ and $(d)]$ and $2016[(e)$ and (f)]

Figure 25. Daily transpiration (morning on the top of the figure and afternoon, on the bottom) of Bobal (left) and Verdejo (right) potted vines in north-south (NS; •) and eastwest $(\mathrm{EW} ; \bullet)$ vineyard row's orientation in 2014

Figure 26. Scatter plot relating potted-vines daily transpiration of Bobal in north-south (NS; •) and east-west (EW; •) and of Verdejo in north-south (NS; $\nabla$ ) and east-west (EW; $\boldsymbol{\nabla}$ ) vineyard row's orientation in 2014/16.

Figure 27. Overview of the Tempranillo vineyard; first row: Irrigated-Defoliated vines; second row, Irrigated-Undefoliated vines 125

Figure 28. Appearance of Boba Irrigated-Defoliated vines at full-veraison in 2014 126

Figure 29. Seasonal patterns of the daily maximum air temperature (๑), mean air temperature $(\bullet)$ and minimum air temperature $(\nabla)$ in Requena, Valencia, Spain. The day of year (DOY) follows a continuous time scale starting on 01/01/2014. Rainfall is represented with blue bars and reference evapotranspiration $\left(\mathrm{ET}_{0}\right)$ with green bars. The moment of occurrence of late leaf removal in Bobal ( $\star$ ) and in Tempranillo ( $\star$ ) and the latest harvest for Bobal (\$) and for Tempranillo (\$) are indicated for each season.

Figure 30. Effect of irrigated-undefoliated (IU; ๑), irrigated-defoliated (ID; ○), rainfedundefoliated (RU; $\nabla$ ) and rainfed-defoliated (RD; $\nabla$ ) treatments on the seasonal evolution of midday stem water potential ( $\left.\Psi_{\text {stem }}\right)$ of Bobal [(a) and (b)] and Tempranillo [(c) and (d)] vineyards in 2014 [(a) and (c)] and 2015 [(b) and (d)].

Figure 31. Effect on stomatal conductance $\left(\mathrm{g}_{\mathrm{s}}\right)$, transpiration $(\mathrm{E})$ and photosynthesis $(\mathrm{A})$ leaf rates of the irrigated-undefoliated (IU; $\square$ ), irrigated-defoliated (ID; $\square$ ), rainfedundefoliated (RU; $\square$ ) and rainfed-defoliated (RD; $\square$ ) treatments of Bobal [(a), (b) and (c)] and Tempranillo [(d), (e) and (f)] vineyards during the two experimental seasons 135

Figure 32. Bobal trial: grape effects on the seasonal evolution of berry fresh weight in 2014 (a) and in 2015 (b), total soluble solids (TSS) in 2014 (c) and in 2015 (d), titratable acidity 
Index

in 2014 (e) and in 2015 (f), and anthocyanins concentration in 2014 (g) and in 2015 (h) in irrigated-undefoliated (IU; $\bullet$ ), irrigated-defoliated (ID; $९$ ), rainfed-undefoliated (RU; $\nabla$ ) and rainfed-undefoliated (RD; $\nabla$ ) vines from the date of late leaf removal was applied until harvest. 140

Figure 33. Tempranillo trial: grape effects on the seasonal evolution of (a) berry fresh weight in 2014 and (b) in 2015, (c) total soluble solids (TSS) in 2014 and (d) in 2015, (e) titratable acidity in 2014 and (f) in 2015, and (g) anthocyanins concentration in 2014 and (h) in 2015 of the irrigated-undefoliated (IU; O), irrigated-defoliated (ID; $)$ ), rainfedundefoliated (RU; $\nabla$ ) and rainfed-defoliated (RD; $\nabla$ ) treatments from the date of late leaf removal was applied until harvest

Figure 34. Effect of irrigated Control (IU; 0 ), irrigated defoliated (ID; $\odot$ ), rainfed control $(\mathrm{RU} ; \boldsymbol{\nabla})$ and rainfed defoliated (RD; $\nabla$ ) treatments on the relationship between total soluble solids (TSS) accumulation in berries and titratable acidity (TA) for (a) Bobal plot in 2014 and (b) in 2015, (c) Tempranillo plot in 2014 and (d) in 2015 142

Figure 35. Factors affecting assimilation and transpiration of canopies 154 


\section{OUTLINE OF THE THESIS}

This document is structured in 6 chapters. The chapters introduce the possible effects of climate change on Mediterranean winegrowing sector and present a set of viticultural practices for its adaptation. Chapters II, III and IV assess three specific strategies and lastly, a general discussion and conclusions are presented.

\section{Chapter I: INTRODUCTION}

This chapter provides an overview of the concept of climate change and the predictions for Mediterranean-like climatic regions. It also presents the overall grapevine cultivation and the Spanish wine sector, addressing the impacts and challenges of climate change on Mediterranean viticulture. Furthermore, it enumerates possible field practices for adapting the wine industry to climate change. Lastly, this chapter presents the general objectives and a brief outline of the Thesis.

\section{Chapter II: DEFICIT IRRIGATION FOR IMPROVING WATER-USE EFFICIENCY AND GRAPE COMPOSITION IN VITIS VINIFERA L. CV. MUSCAT OF ALEXANDRIA}

This chapter evaluates regulated deficit irrigation techniques as a possible strategy for adapting Mediterranean viticulture to water scarcity, aiming to improve water-use efficiency as well as grape composition. The results of the different irrigation strategies on cv. Muscat of Alexandria are discussed.

\section{Chapter III: VINEYARD ROW'S ORIENTATION EFFECTS ON WATER-USE EFFICIENCY AND GRAPE COMPOSITION OF POTTED GRAPEVINES CVS. VERDEJO AND BOBAL}

In this chapter, the effects of solar radiation interception by the canopy in response to the vineyard hedgerow's orientation on water-use efficiency and grape composition are evaluated. The responses of Verdejo and Bobal cvs. to the north-south or east-west orientation are discussed. 


\section{Chapter IV: DELAYING BERRY RIPENING BY LATE LEAF REMOVAL FOR} AMELIORATING GRAPE AND WINE COMPOSITION OF CVS. BOBAL AND TEMPRANILLO

In this chapter, the effects on grape and wine composition of canopy management practices aiming to delay berry-ripening are discussed. This field practice is assessed in Bobal and Tempranillo cvs. under rainfed and deficit irrigation regimes.

\section{Chapter V: GENERAL DISCUSSION}

This chapter includes a general discussion of all the results presented in chapters II, III and IV, and provides a general overview of the possible field practices for adapting Mediterranean viticulture to climate change.

\section{Chapter VI: GENERAL CONCLUSIONS}

The last chapter lists the main conclusions derived from the present Thesis according to the general objectives presented in Chapter I. 
Chapter I

GENERAL INTRODUCTION 


\section{Introduction}

\subsection{Vitis vinifera in Mediterranean-like climatic regions}

Grapevine (Vitis vinifera L.) is a perennial deciduous species of the family Vitaceae with interest to humans since more than 7000 years (Mark 1996). It is native to the Mediterranean region, central Europe and southwestern Asia. Currently, grapevines are widely cultivated in all temperate climates for both wine making and table grape production. V. vinifera is a historic crop in human culture, from leisure to religion, and due to its economic importance, the study of the grapevine culture has motivated many researches. For instance, it is the fourth angiosperm species whose genome has been completely sequenced.

Grapes are very much appreciated for their sweet flavour, acidity equilibrium and aroma. The fruit is formed by berries grouped into clusters. Berry development requires pollination of the vine inflorescence, whose flowers are hermaphroditic. Fruit set in grapevines falls within the range of $30-50 \%$ on average, but it is highly variable between cultivars and it is influenced by many factors such as climate (temperature, humidity, light intensity, wind, etc.) and the vine's carbohydrates reserves (May 2004). Grapes can have dark-coloured skin (red) or light-coloured skin (white). The grape is the sexual organ of vine and, at an ecological level, birds are the principal vector for the plant's dissemination by the dispensing of grape seeds. However, for grapevine cultivation, vines are reproduced through cuttings. Vitis vinifera is nowadays mainly grafted onto other species from the Vitis genus. These rootstocks confer desirable characteristics to the root system, including the resistance to the phylloxera pest. Rootstocks are usually hybrid varieties developed by crossing between the Vitis berlandieri, Vitis riparia and Vitis rupestris species. Notwithstanding, all the most familiar winegrape scions belong to $V$. vinifera.

The thermal thresholds in which vine can grow are broad, and range from mean temperatures of 10 to $40^{\circ} \mathrm{C}$, with an optimum around $22-25^{\circ} \mathrm{C}$. Because of this, at present, viticultural regions are widespread in many geographical areas found between $30^{\circ}$ to $50^{\circ} \mathrm{N}$ and $30^{\circ}$ to $40^{\circ} \mathrm{S}$ (Schultz and Jones 2010). The diurnal temperature range, which is related to the altitude, controls phenology and favours accumulation of protective compounds within the tissues (Gladstones 2011). Temperature indeed plays a major role in the physiology of the vine and influences grape maturation, including the aroma and the coloration (Coombe 1987, Jackson and Lombard 1993). Light interacts with temperature to 
govern photosynthesis and therefore carbon assimilation as well as grape ripeness and phenology regulation.

The Mediterranean climate is widely variable, including regional weather fluctuations characterized by energetic mesoscale features. The Mediterranean climate is not restricted to the Mediterranean basin and occurs on the west side of continents between about $30^{\circ}$ and $40^{\circ}$ latitude. Mediterranean-like climatic regions cover areas in British Columbia (Canada), California (U.S.A.), Chile, South Africa, South Australia or Central Asia. Overall, the Mediterranean climate is temperate, typified by warm to hot and dry summers, and mild and relatively wet winters. Temperature variations between summer and winter are moderate due to the buffer effect of the proximity of large bodies of water. Only occasionally, the air temperature exceeds $40^{\circ} \mathrm{C}$ in summer time or falls below $0^{\circ} \mathrm{C}$ in winter. Annual precipitation ranges from 200 to $1,400 \mathrm{~mm}$, of which at least $65 \%$ occurs during winter (Köppen 1936). The summer season is characterized by a seasonal drought, because the reference evapotranspiration $\left(\mathrm{ET}_{0}\right)$ is much higher than rainfall. This period of water deficit coincides with the grapevine growing season. Vine performance and grape composition under the Mediterranean climate is mainly typified by the high solar radiation received and a deficit in soil water availability. Certainly, water is the most limiting factor in the Mediterranean region, characterized by being a drought-prone area. This trait traditionally has been considered closely related to the grape organoleptic properties. Both solar radiation and water availability can be controlled by means of training systems, canopy and soil water management.

\subsubsection{Winegrape sector in Spain}

In the Iberian Peninsula, Vitis vinifera has been cultivated since the XI to II century BC when Iberians and Celtiberians inhabited the region (Hidalgo 1999). Nowadays in Spain grapevine is planted in 968,769 hectares, approximately in $19.3 \%$ of the national surface occupied by woody crops, and the $5.7 \%$ of total arable land (MAPAMA 2016). Worldwide, grapevine is the most cultivated woody perennial crop (Delrot et al. 2010) but, even then, grapevine cultivation represents less than the $0.5 \%$ of the world's arable land. Moreover, the global winegrape cultivation surface has declined during the XXI century, but this varies among the different countries. In the "new wine regions", the trends in vineyard surface area are steady (North America) or increasing (Argentina, Chile, South Africa, New Zealand, and between 2015 and 2016, particularly China); while in the "older wine regions" 
(Europe), especially in Spain, France and Italy, grapevine cultivation has shown a marked reduction (OIV 2017). However in Spain, the vineyard area reduction has been stabilised in the period from 2013 to 2016 (OIV 2017).

European countries have the largest wine-growing area in the world, with around $43 \%$ of the 7.6 Mha occupied in the world with grapevines (OIV 2017). Spain is the country with the largest vineyard surface, but not with the greatest grape production (MAPAMA 2016). Indeed, Spain is the third-largest wine producer country in volume (39.4 MhL), after France (43.5 MhL) and Italy (51 MhL) (OIV 2017). Remarkably, Spanish grape production has increased during the XXI century despite the reduction in surface. This is due to the higher vine productivity achieved by means of new agronomic practices, new cultivars and clones, and changes in land cover use.

The biggest Spanish producing region is Castilla-La Mancha, which comprises $48.9 \%$ of total vineyard surface in the country. It is followed by Extremadura (8.6\%), Comunidad Valenciana (7.0\%), Castilla y León (6.7\%), Cataluña (5.7\%), and La Rioja (5.4\%) (MAPAMA 2016). The Spanish wine sector is mainly structured into the Designation of Origin (DO), among other classifications or its equivalent concept of origin (PDO) in the European Union. The major DOs in Spain per wine volume are La Rioja, La Mancha, Jumilla, Utiel-Requena, Valdepeñas and Penedés, with $65 \%$ of the national production. Sixty percent of the DO wine remains in the domestic market and the rest is exported. Currently, Spain is the biggest wine exporter, with 22.9 MhL and a global market share of 22\%. Nonetheless, the Spanish turnover corresponds to only the $9.2 \%$ of the total international trade value ( 28.9 bn Euros) (OIV 2017).

Spanish grape yield is characterized by important season-to-season variations mainly because of the high dependency of the winegrapes sector on seasonal pluviometry. In fact, soil water availability is the main regulator of vine yield in Spanish terroirs, as the $60.7 \%$ of Spanish vineyard surface is rainfed (MAPAMA 2016). Since 1996, when winegrapes irrigation in Spain was first allowed, the vineyard irrigation surface has continued to increase. This technological advancement is the main aspect responsible for the increase in the Spanish vineyards' yield, also resulting in a better control over vine performance and grape composition.

The Spanish wine production is characterized by both white and red wines, in similar proportion. There are probably more than 200 different varieties cultivated regardless synonymies. Among them, Airén, Tempranillo, Bobal, Garnacha, Macabeo, 
Monastrell and Cayetana Blanca represent over $70 \%$ of the total vineyard surface (MAPAMA 2015). However, the varietal heritage of Spain is extremely rich and broad due to the classic vine growing activities and the edaphic and climatic diversity of the territory (Hidalgo 1999). Other important grapevine Spanish cultivars are the whites Verdejo, Palomino, Moscatel de Alejandría and Xarello or the reds Garnacha Tintorera, Mencía and Mazuela.

The Spanish wine industry has evolved continuously during its history, from the inception of the phylloxera epidemic in the late $19^{\text {th }}$ century to the adaptation to current changes in wine demand. In the near future, one of the main challenges the wine sector will have to face is climate change (Jones and Webb 2010, Schultz and Jones 2010, Hannah et al. 2013).

\subsubsection{Vine water relations}

Vitis vinifera is a plant with marked tolerance to water stress because of its powerful root system and its physiological regulation capacity. Nevertheless, grapevine potential evapotranspiration under Mediterranean climates could reach similar values than the reference evapotranspiration ( $\left.\mathrm{ET}_{0}\right)$, as López-Urrea et al. (2012) and Picón-Toro et al. (2012) determined by means of weighing lysimeters. When the potential vine evapotranspiration $\left(\mathrm{ET}_{\mathrm{c}}\right)$ is not satisfied, vines will suffer some degree of water stress, which reduces yield and vegetative growth, particularly leaf area (Gómez-del-Campo et al. 2002, Intrigliolo and Castel 2008, Uriarte et al. 2014). Indeed, soil water availability is the most critical factor influencing crop load (Williams and Matthews 1990, Medrano et al. 2003, Chaves et al. 2007). Water deficit can limit not only vine performance, but also grape and wine composition (Hardie and Considine 1976, Jackson and Lombard 1993).

Vine responds to water stress through stomata regulation to minimize transpiration, decreasing its photosynthetic capacity and thus causing assimilation decline (Flexas and Medrano 2002, Lovisolo et al. 2010). This could decrease the accumulation of grape primary and secondary metabolites (Esteban et al. 2001, Downey et al. 2006, Romero et al. 2010a). Moreover, severe water stress provokes damages to the correct functioning of leaves and roots due to the changes in hydraulic conductivity, namely shifts in hydraulic architecture, embolisms, and xylem cavitation or through osmotic adjustment (Lovisolo and Schubert 1998, Keller 2010b). Irrigation alleviates vine water stress symptoms while increasing yield, especially in arid climates, although vine performance also depends on the climate 
and soil characteristics (Mirás-Avalos and Intrigliolo 2017). In fact, vine performance and grape composition can be affected by many interactive factors influenced by vine water stress such as crop load, total leaf area, yield components (shoot fruitfulness, berry number per cluster or berry and cluster size), physiology, among others (Intrigliolo et al. 2012). This is why satisfying the entire vine water requirements usually reduces grape aptitudes for elaborating high quality wines (Chapman et al. 2005, Deluc et al. 2009).

Leaf water potential is one of the most reliable indicators of vine water status (Choné et al. 2001, Baeza et al. 2007), and it can be measured either at pre-dawn or at midday (Williams and Araujo 2002, Intrigliolo and Castel 2006, Santesteban et al. 2011b). When measured at midday, water potential can be determined in fully transpiring leaves that are well exposed to solar radiations $\left(\Psi_{\text {leaf }}\right)$ or in shaded bagged leaves to avoid leaf transpiration (stem water potential, $\Psi_{\text {stem }}$ ). Both methods are generally employed since they are often quite tightly correlated, particularly under mild water stress conditions (Intrigliolo and Castel 2006). As vine water potential is influenced by meteorological conditions, the relationship between $\Psi_{\text {stem }}$ or $\Psi_{\text {leaf }}$ and vapour pressure deficit (Smart and Barrs 1973) can be used to establish an non-water stressed baseline under semiarid grapegrowing regions (Williams and Baeza 2007).

There are other methods to assess vine water status, such as: dendrometry (Intrigliolo and Castel 2007), sap-flow measurement (Ginestar et al. 1998, Zhang et al. 2011), leaf turgor pressure (Rüger et al. 2010), thermography (Jones et al. 2002, Fuentes et al. 2012) or the isotopic carbon ratio determination (de Souza et al. 2005b, Santesteban et al. 2015). Notwithstanding, vine water stress, even accounted for during the whole phenological cycle (comprehensive water stress), might not correlate well with the agronomic response or grape quality (Baeza et al. 2007). This is due to the high dependence of vine performance and grape composition on the phenological timing when water shortage takes place (García Escudero et al. 1991, Girona et al. 2009, Intrigliolo et al. 2012).

Understanding the relationship of vine water status with stomatal conductance is basic when aiming to increase the assimilation efficiency (carbon dioxide assimilated photosynthetically per water transpired) by means of irrigation scheduling (Cifre et al. 2005, Romero and Martinez-Cutillas 2012). However, these physiological regulation mechanisms are very complex because they are influenced by many cell biology or hormonal regulations and the vines' interactions with the soil-plant-atmosphere continuum (Sperry et al. 2003, Lovisolo et al. 2010). For instance, salinity in the soil water solution 
affects water relations, limiting vine photosynthesis together with vegetative cell growth (Cramer et al. 2007, Chaves et al. 2009). Notwithstanding, there is genetic variability in grapevine stomatal sensitivity to water stress, and thus in its intrinsic water-use efficiency (Mullins et al. 1992, Martorell et al. 2015).

\subsubsection{Grapevine training systems and canopy management}

Training systems and canopy management determine the amount of radiation intercepted by grapevines and their effects on vine performance and grape composition have been widely studied (Smart et al. 1990, Schultz 1995, Dry 2000, de Cortázar et al. 2005, Bates 2008). However, the interactions of vine canopy with the vineyard's environment are still not fully understood (Reynolds et al. 2004, Peterlunger et al. 2002, Vanden Heuvel et al. 2004). Canopy radiation absorption influences vine photosynthesis and thus it is linked to vineyard productivity, vegetative development or carbohydrate storage, and in turn, with water consumption (Chaves 1986, Baeza et al. 2005). In fact, grapevine water-use and its crop coefficient are linear functions of the light intercepted, measured by (Williams and Ayars 2005) as the shaded area beneath the canopy. Therefore, vineyard canopy architecture should be designed for searching for the desired vine size, canopy light exposure and cluster microclimate conditions (light, temperature, humidity and evaporation). Leaf mutual shading decreases assimilation efficiency because shaded leaves require nutrients and water supply, but its carbon assimilation is very low (Smart and Barrs 1973, Poni et al. 2003, Medrano et al. 2012). This is due to the extinction of solar radiation through the leaf area interception and the low weight of diffuse radiation in photosynthetic active radiation. Additionally, high leaf density promotes fungal diseases in grape due to the low aeration of the clusters.

The training system structure and geometry is defined by means of vine pruning or vine training during the first years of formation (Keller et al. 2004, Bernizzoni et al. 2009). Pruning systems are used for constraining vegetative vigour while maintaining a perennial structure capable of sustaining the optimum level of bud fruitfulness initiation and differentiation. In Mediterranean-like climatic regions, grapevine is winter pruned to improve shoot vigour and to reduce and balance the number of clusters, aiming at better ripening (Smart 1985). Also, pruning attempts to improve sap flow distribution and delay aging (Hidalgo 1999). Another goal for the application of training, is to facilitate mechanisation of pruning or harvesting or the efficiency of phytosanitary application. 
During grapevine pruning, the number of buds retained per plant is very low as compared to other woody species. Moreover, in some PDO regions, the number of buds per plant to be left after pruning is even regulated by law.

The most popular winter pruning systems are: 1) spur pruning, 2) cane pruning and 3) “Gobelet", “Globet” or "Vase” (Carbonneau 2009, Dokoozlian and Wolpert 2009). The first two require a trellis system to manage the canopy, while the vase system does not require the use of catching wires or other systems of support (Figure 1). The Gobelet structure is its own wood, resulting from years of spur and cane pruning. It is typical in warm and dry climates without fertile soils. The Globelet's bushy architecture might result in excessive shading which on the one hand reduces evaporative demand of shaded fruits and leaves but, on the other hand increases risk of rot in humid environments.

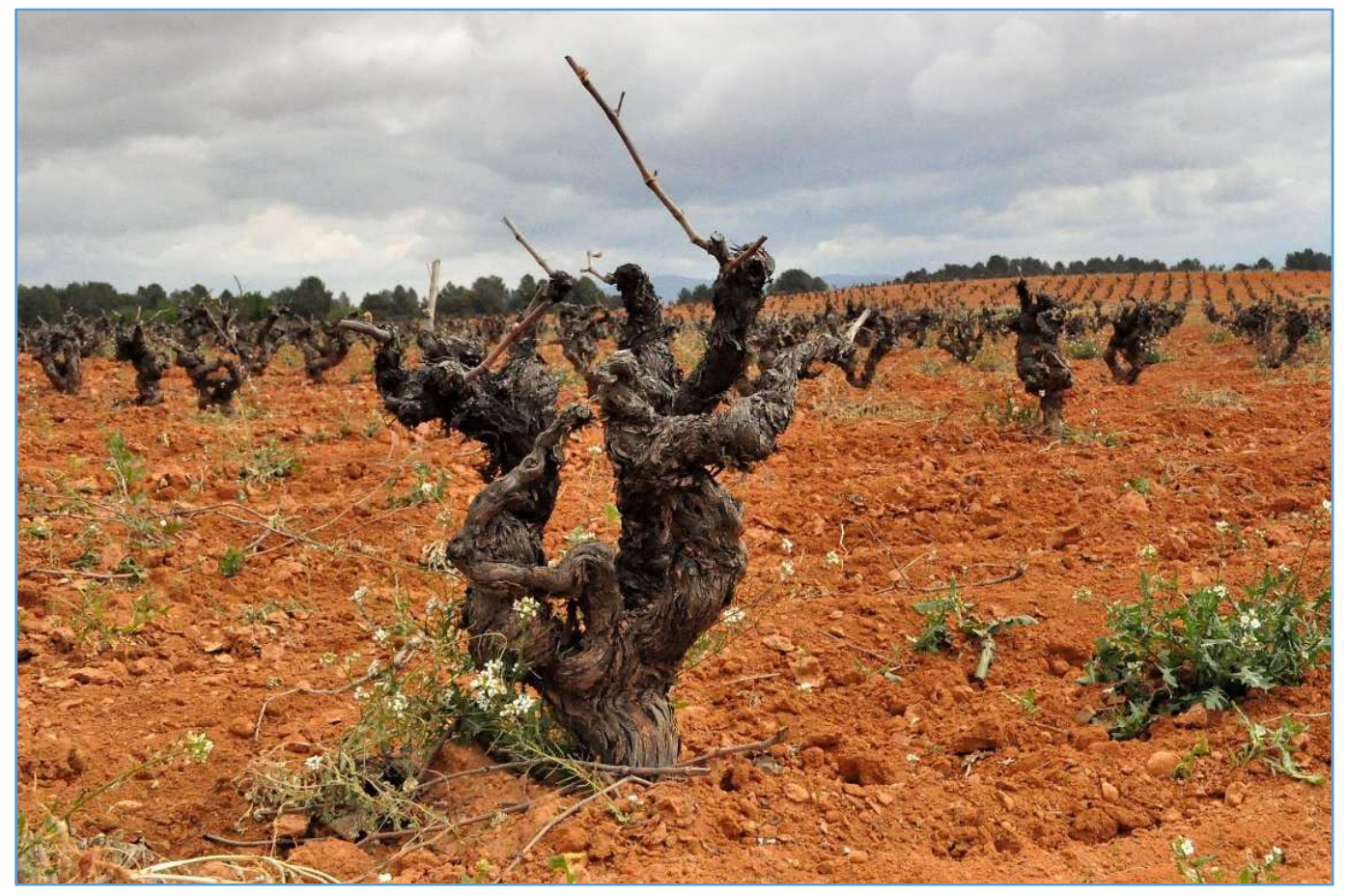

Figure 1. Vase system in an old vine combining spur and cane pruning (Requena, Spain).

In trellis systems, the canopy is organized between wires fixed to posts running the length of the vine row. One of the most popular trellis system is the bilateral spur pruned cordon which consists of pruning canes usually down to two nodes, with the canopy organized into a vertical shoot positioned (VSP) system or in single high-wire cordon (sprawl) (Palliotti et al. 2014). This means, having the shoots completely tidy between the wires (VSP) or only in between two low wires (simple curtain or sprawl). Other spurpruned system are the Geneva Double Cordon (GDC) or the Open Lyre, which consist on the 
division of the canopy into two (Carbonneau and Casteran 1987, Palliotti et al. 2012). In the GDC, the shoots create foliage curtains hanging down towards the ground while in the Open Lyre the canopy is grown upward between wires into a V-shape. These systems aim to improve radiation interception in vigorous vines while thinning the canopy density. Another widely-used training system under non-water limitations is the "Tendone", "Pergola" or "Parral" (Figure 2). It consists in grown grapes hanging in a trellis structure overhead, being shaped as a dense canopy roof. It is often used for table grape production rather than wine. These training systems are often adapted by combining them. For instance, the Gable trellis system or roof inclined in opposition is a mixture of Open Lyre and Parral (Figure 3).

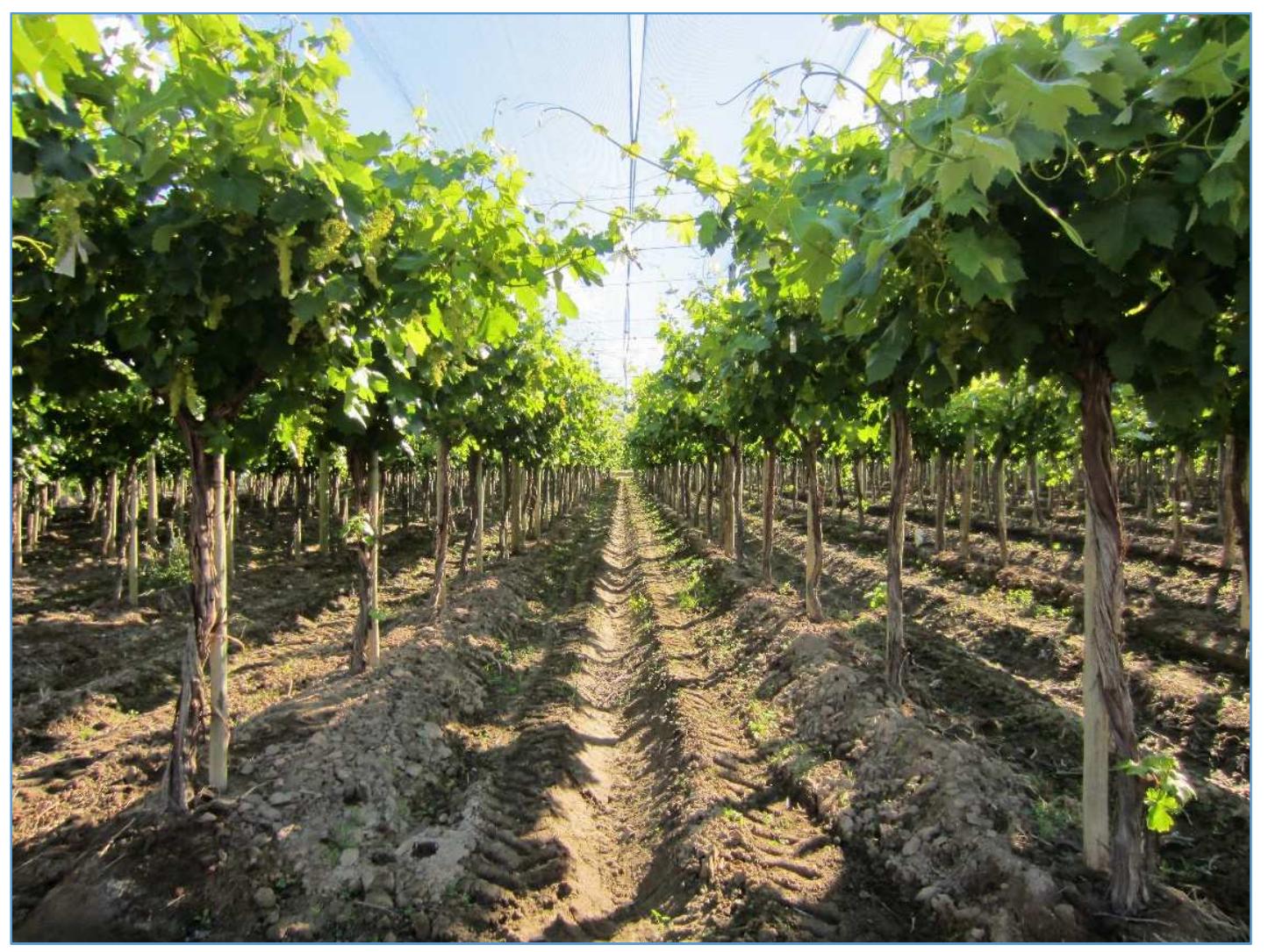

Figure 2. Parral training system combining spur and cane pruning (Mendoza, Argentina).

Among the cane pruning systems, the most widely used are the simple Guyot, double Guyot or the "Scott Henry". These systems use cordon training and consist on preserving canes intact, although shortened, and one spur, which is retained for the replacement of the cane that is completely removed every season. This aims to improve shoot fruitfulness and is more common in regions without water shortages and in varieties with low basal bud's fruitfulness. In the Scott Henry system, the fruiting canes of the upper cane are trained upwards, whereas those of the lower cane are allowed to fall downwards. A similar training 
method is the "Smart Dyson", with the modification of the double cane pruning for spur pruning.

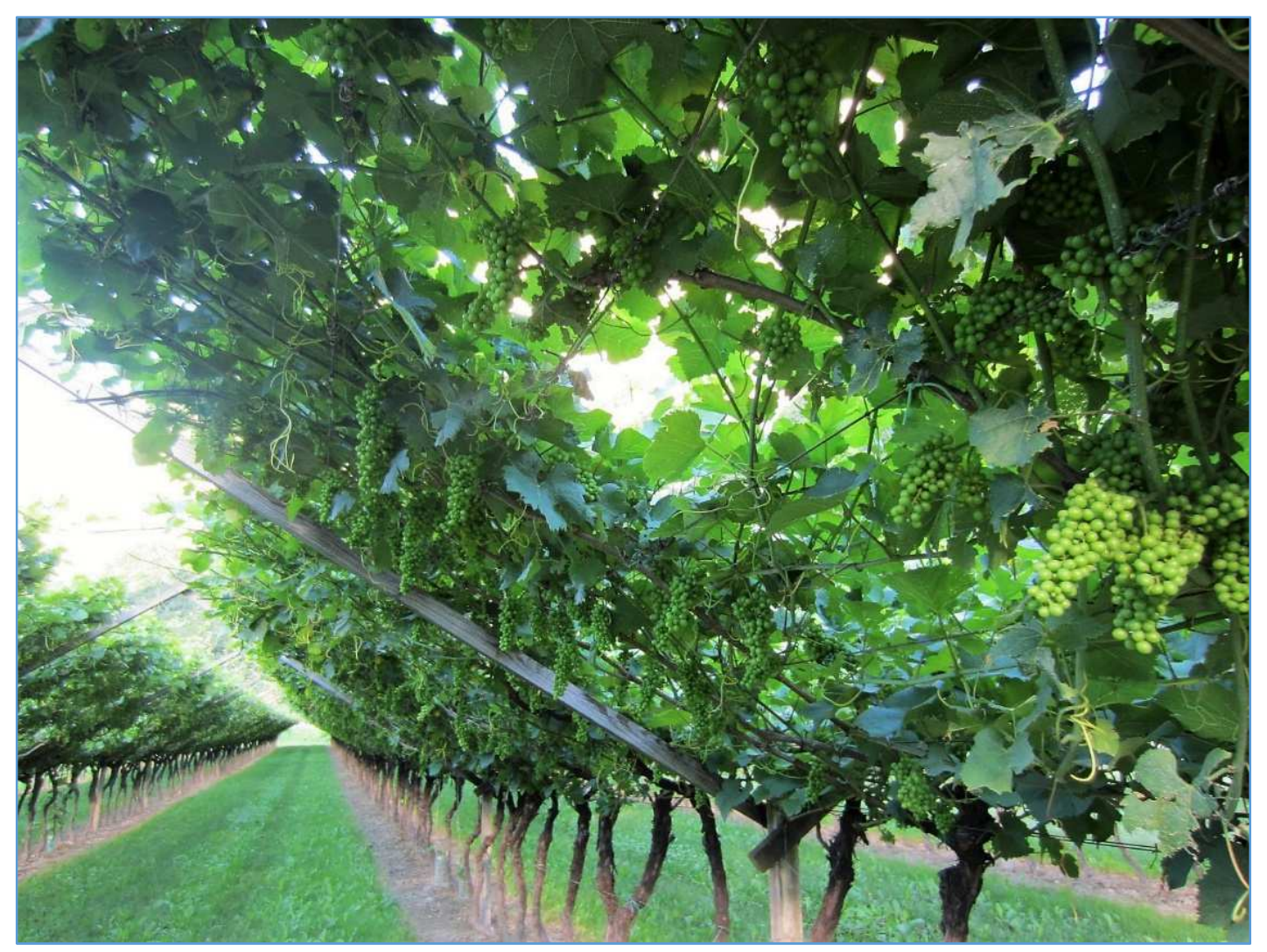

Figure 3. Gable trellis system in a vigorous vineyard (Bolzano, Italy).

Canopy management is the manipulation of the architecture of the leaf canopy in order to beneficially alter the microclimate around the vine. It includes shoot positioning for a given training system, but also other field operations during the vegetative growth stage such as the removal of young shoots, partial defoliations or shoot trimming. Canopy management indeed aims to balance the ratio between total leaf area and yield. This balance is needed to provide appropriate vine capacity to ripen the grape, develop the bud's fruitfulness for the following year and for storing enough reserves.

Grapevine training systems and canopy management are useful tools for adapting viticulture to soil water availability and climate conditions (rainfall, sunlight exposure or wind velocity). However, the relationship between vine growth, grape development, grape aroma and flavour metabolites is very complex as is affected by several factors. Among which we find, for instance, soil fertility, plant densities, row orientation or the genetic material, clone, rootstock and their interaction (Jackson and Lombard 1993, Deloire et al. 2004, Serra et al. 2014). Kliewer and Dokoozlian (2005) stated that the fruiting capacity of 
grapevines in a given climatic region is largely determined by their leaf area and by the percentage of the total leaf surface area that is exposed to full sunlight. They established that the leaf area-to-crop weight ratio required for a proper grape-ripening in single trellistraining systems (VSP), ranged between 0.8 and $1.2 \mathrm{~m}^{2}$ per $\mathrm{kg}$ of fruit. But when the canopy was divided (GDC, lyre, etc.), the optimum leaf area-to-fruit ratio needed for proper grape ripening was reduced to only 0.5 to $0.8 \mathrm{~m}^{2}$ per $\mathrm{kg}$ of fruit. This is due to the increase in the radiation intercepted by leaf area in these training systems in absence of other limiting factor such as water stress. In fact, in Mediterranean climates, the use of a divided canopy is not recommended due to water scarcity, and thus low vine vigour. This is because water relations affect canopy growth, determining the more appropriate training system and vineyard design. Furthermore, vine water status modulates the vine's physiological response to the radiation intercepted. For instance, Mirás-Avalos et al. (2017) in a trial carried out in semiarid conditions under different degrees of water stress and canopy management practices, observed that vine water status better explained the differences in vine growth, yield and grape composition than the leaf area-to-yield ratio among the experimental treatments studied. This suggested that vine performance under Mediterranean-like climatic regions was more influenced by water availability than by the amount of sunlight intercepted. 


\subsection{Climate change impacts on Mediterranean-like viticulture}

The Intergovernmental Panel on Climate Change (IPCC) of the United Nations has published its model projections of climate change for this century, warning of many impacts on agriculture. Climate warming is unquestionable since the 1950s, because many of the observed changes are unprecedented over decades to millennia (IPCC 2014). For instance, the atmospheric concentrations of carbon dioxide, methane and nitrous oxide are unprecedented in at least the last 800.000 years. Anthropogenic greenhouse gas (GHG) emissions are accelerating changes in global climate. Particularly, the agriculture sector's GHG emissions contributed to the global warming potential by 22\% from 1990 to 2010 (IPCC 2014). Figure 4 shows the average global surface temperature anomaly combining land and ocean surface since 1850 until 2012. Throughout the period, a temperature increment of $0.85 \pm 0.2^{\circ} \mathrm{C}$ can be observed. During the summer the expected increases in temperature will be even greater, which is when the grapevine growing season takes place. However, global warming is not distributed evenly (Figure 6). For instance, Ramos et al. (2008) found an overall increase of 1.0 to $2.2^{\circ} \mathrm{C}$ from 1952 to 2006 in the Alt Penedès, Priorat, and Segrià regions of north-east Spain.

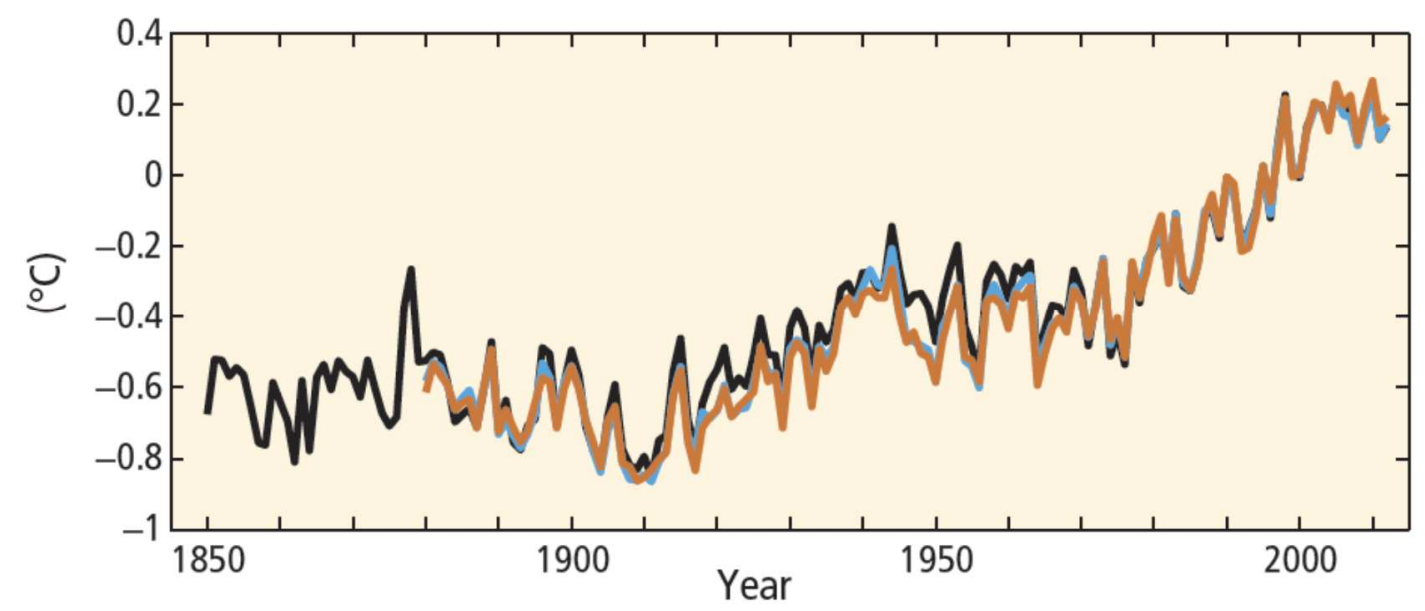

Figure 4. Annual-global average (black) of combined land (brown) and ocean surface (blue) temperature anomalies relative to the average over the period 1986 to 2005 (IPCC 2014).

Climate change effects may have inertia, and thus greater impacts are expected in the future. Some effects could trigger a ripple effect (tipping point) such as the partial melting of superficial permafrost (37-81\% depending on the future scenario) which would release methane to the atmosphere, increasing warming, and recursively causing more permafrost thawing (Schaefer et al. 2014). Overall, the IPCC (2014) climate models predict an increase in global mean surface temperature ranging from $0.3^{\circ} \mathrm{C}$ to $4.8^{\circ} \mathrm{C}$ for the end of 
the $21^{\text {st }}$ century (2081-2100) relative to $1986-2005$ and depending on the future scenario (Figure 5).

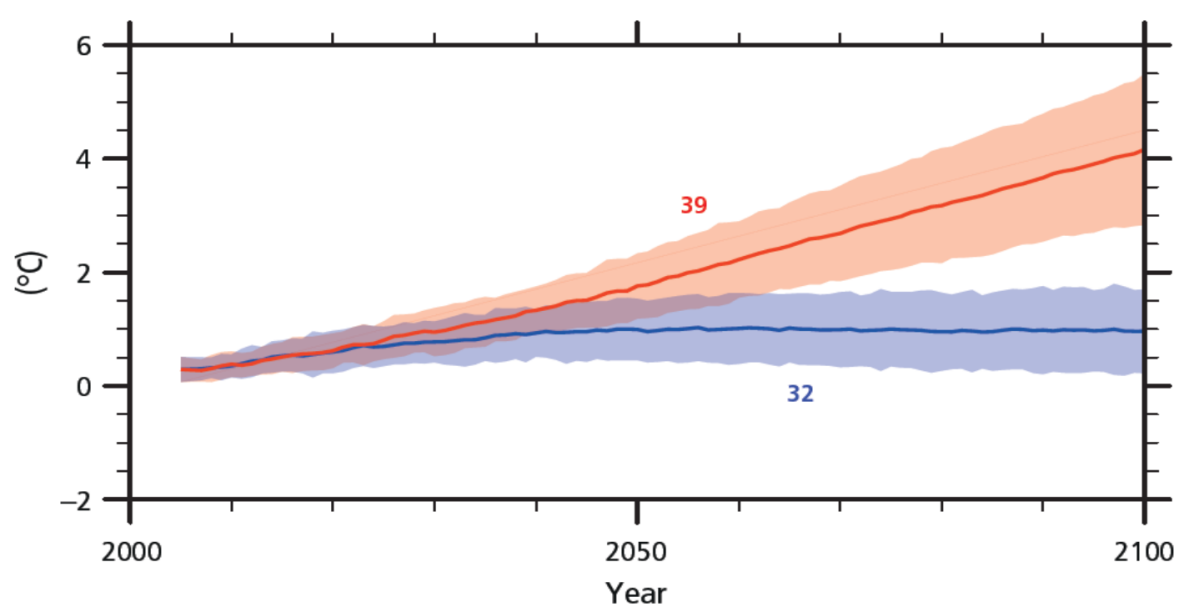

Figure 5. Global average surface temperature change from 2006 to 2100 as determined by multi-model simulations (IPCC 2014). Time series of projections and a measure of uncertainty (shading) are shown for different scenarios (Coupled Model Intercomparison Project Phase 5).

Recent climate assessment projections forecast extreme alterations in frequency, intensity, spatial extend and duration of meteorological phenomena (IPCC 2014). These include climate and hydro-meteorological events such as heat waves, decreases in extreme cold temperatures, droughts or heavy precipitation events and floods. The past occurrence of extreme events has revealed a significant vulnerability and exposure of some ecosystems and human systems to climate variability. In recent decades, changes in climate have caused global impacts on natural and human systems, in all continents and across the oceans (IPCC 2014). These effects are not always negative and can even be beneficial for some communities in certain places. But the adaptability of ecosystems to such rapid changes is in question.

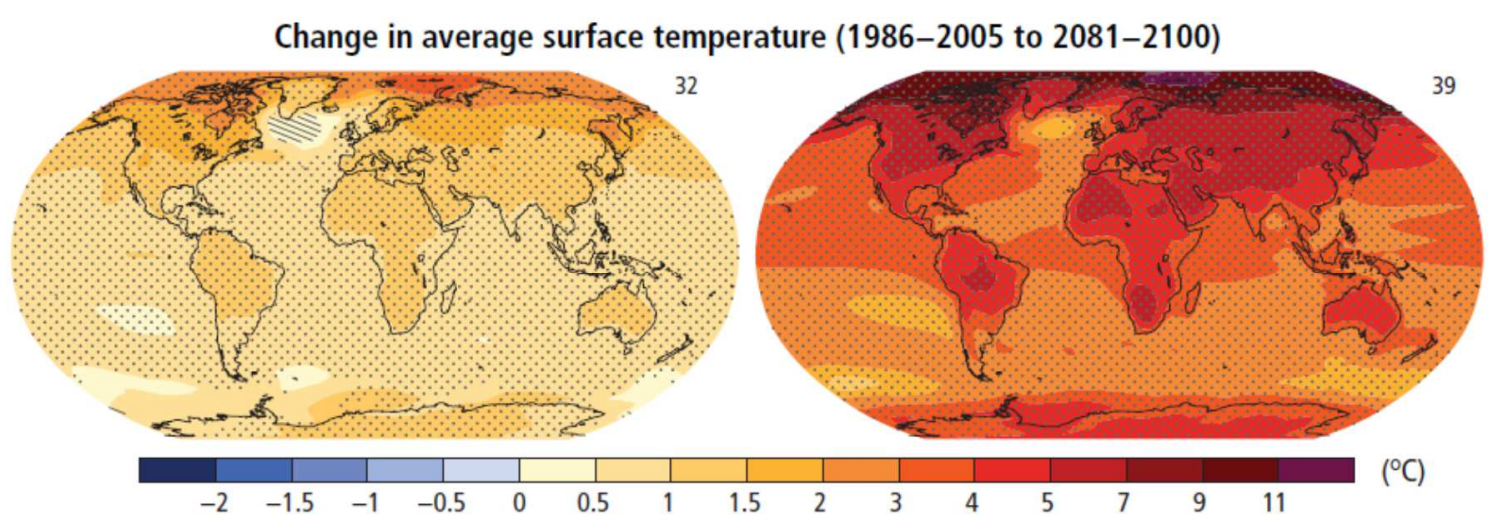

Figure 6. Mean projections for the 2081-2100 period under for different scenarios for the percentage of annual mean surface temperature (Coupled Model Intercomparison Project Phase 5, IPCC 2014). 
Global warming has likely affected the global water cycle since the 1960s (IPCC 2014). The retreat of glaciers and the ice surface, hydrological systems alterations and the rise of global mean sea level are well-known examples. Focusing on the Mediterranean climates, many reports have shown negative precipitation trends during the last decades (Brunetti et al. 2004, Dai et al. 2011). Although due to the strong decadal variability of the precipitation series, other authors found this trend to be only consistent for the winter period (Giorgi 2002). This was also the outcome of Fortuny (2015) models for the northern Mediterranean region, which explained the drying winter trends by the effect of a pattern in the upward direction in the North Atlantic Oscillation observed in the last decades.

Climate models predict a global increase in aridity during the twenty-first century which will particularly affect many regions such as most of Africa, southern Europe and the Middle East, most of the Americas, Australia, and Southeast Asia (Sheffield and Wood 2008, Dai 2011). The IPCC (2014) also prognosticates mean precipitation decrements in many mid-latitude and subtropical dry regions (Figure 7), with the more severe reductions occurring in summer (Bladé et al. 2012). In the Mediterranean region, despite there is lowconfidence on the predicted decreasing trends in seasonal precipitation, most of the studies agreed on a change in the in-year precipitation pattern with higher rainfall in autumn and winter and lower precipitation in summer (Chaouche et al. 2010, Molina-Navarro et al. 2014). Moreover, Gates and Liess (2001) reported that the expected erosion and deforestation will reduce soil evaporation and plant evapotranspiration, probably resulting in a reduction of precipitation during the summer. In Mediterranean-like climatic regions, precipitation patterns are very likely to shift to more consecutive days of dryness with rainfall being more torrential leading to significant decrements in the soil moisture retention (IPCC 2012). Given this scenario, the increased risk of drought would be the most dramatic for the Iberian Peninsula (Schultz 2000, Diffenbaugh and Giorgi 2012)

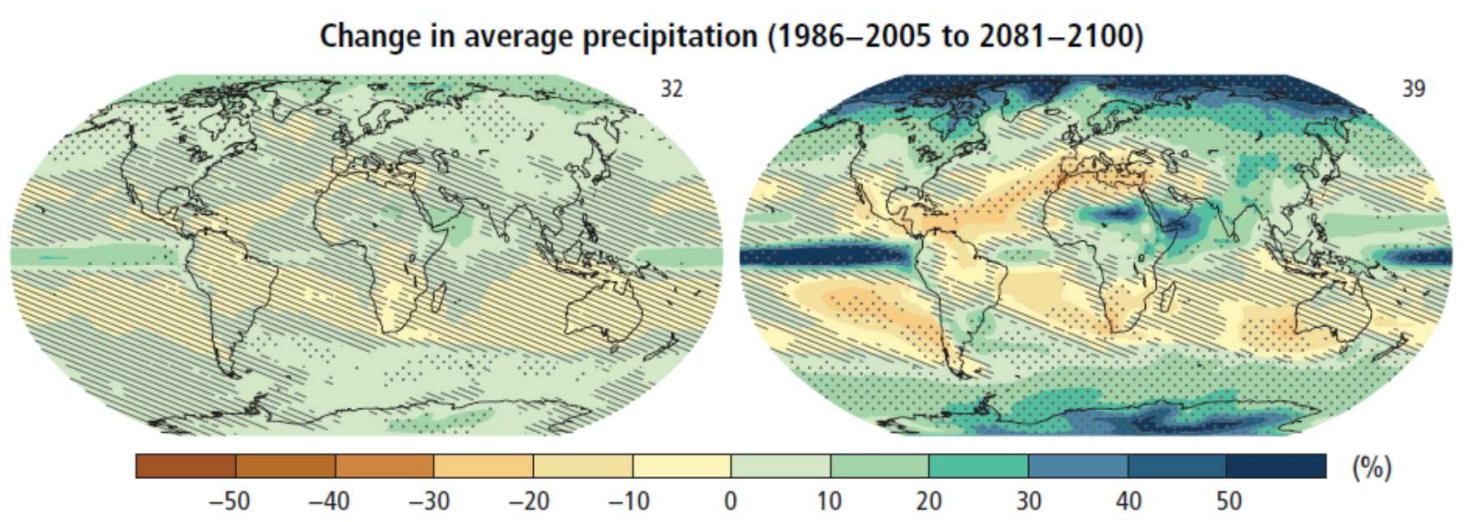


Figure 7. Mean projections for the 2081-2100 period under for different scenarios for the percentage of change in annual mean precipitation (Coupled Model Intercomparison Project Phase 5, IPCC 2014).

In addition to the changes in precipitation patterns, global warming will entail a greater probability of winter rainfall instead of snow. Consequently, runoff will be increased, and most rivers' flow rates will diminish during summer (Betts et al. 2007, Mastin 2008). The meteorological drought will affect freshwater resources in terms of quantity (hydrological drought), and most notably, less water available during the peak of the irrigation season (agricultural drought). Moreover, climate change does not only affect water resources but also leads to water demand increases (Döll 2002). The higher temperature and the relative humidity reductions will increase the evaporative demand. However, the increase in the atmospheric concentration of $\mathrm{CO}_{2}$ will act to control the plant's stomatal conductance $\left(\mathrm{CO}_{2}\right.$ physiological forcing $)$, which will decrease the evapotranspiration flux to the atmosphere (Bindi et al. 2001, Boucher et al. 2009). Nevertheless, the effects of $\mathrm{CO}_{2}$ on water consumption remain unclear because of the complex interactions with elevated temperature (Schultz and Stoll 2010, Martínez-Lüscher et al. 2015b). Overall, higher evaporation coupled with declining water availability will increase freshwater salinity (Schultz 2000, Keller 2010a, Connor et al. 2012).

According to the IPCC model's projections, the Mediterranean-like climate seems to be especially vulnerable to climate change, which has a direct influence on viticulture, as it is mainly concentrated in these regions. Indeed, the outputs of climatic models indicate major global geographic shifts in the suitability for viticulture. Some authors have predicted that current aptness areas are projected to be retained from $19 \%$ to $73 \%$ (depending on the future scenario) in most of the traditional wine-producing regions by 2015 (Hannah et al. 2013). Other authors are more cautious in evaluating viticulture suitability in the future (Van Leeuwen et al. 2013). Certainly, it is a very difficult challenge to establish precise upper limits by variety for growing high-quality wines. Overall, the suitability of winegrape growing regions is expected to shift upward in elevation and/or poleward. Current grape growing regions are projected to become progressively unsuitable for viticulture due to the increasing temperatures and water deficit; exceeding the known limits tolerated by grapevine cultivation today (Moriondo et al. 2013). In any case, it should be also considered that climate is not the only factor accounting for regional suitability to viticulture. For instance, the soil characteristics as well as other socio-economic features should be considered when assessing the feasibility for a given region for grapevine cultivation (Keller 2010a, Lereboullet et al. 2013b). 
The capacity of ecosystems to absorb stresses while maintaining the same function, structure, identity, and feedbacks is defined as resilience (Walker et al. 2004). Aiming to improve grapevine ecosystem resilience, viticulture must evolve to more sustainable designs. Grapevine crops' resilience to cope with climate change depend on the genetic acclimation ability of the plant material, the biodiversity of the system including the soil, and the availability of natural resources. Therefore, viticulture-ecosystems should be approached as an environmental resource management problem, including cultural practices aiming to adapt vineyards to climate change, namely, buffering viticulture's sensitivity to it (the so-called dumb farmer scenario).

The most remarkable vine aspects affected by climate change are vine phenology, vine performance, vine water requirements, and the grape and wine composition. These aspects and their relationship with drought and high temperature will be addressed in this $\mathrm{PhD}$ Thesis within the context of the Mediterranean climate. But there are other influential factors such as pest and disease incidence (Seem et al. 2000, Salinari et al. 2006), nutritional balance, the increase of atmospheric carbon dioxide concentration on plant physiology (Ainsworth and Rogers 2007) or the possible interaction among themselves (Bloom et al. 2010).

\subsubsection{Grapevine phenology}

Phenology is the study of the relationships between climate and the timing of periodic natural phenomena (Jones et al. 2005b). It mainly concerns the dates of first occurrence of biological process in their annual cycle, such as flowering of plants or insect's metamorphosis. The most popular scales describing grapevine phenological stages are Baggiolini's (1952) and the BBCH-scale (Lorenz et al. 1995).

Grapevine phenology is driven by temperature (Parker et al. 2011). Therefore, climate change directly impacts $V$. vinifera phenological stages (Lebon 2002, Schultz and Jones 2010, Cook and Wolkovich 2016). In fact, the period between budburst and harvest is becoming shorter and earlier worldwide (Nemani et al. 2001, Duchêne and Schneider 2005, Moriondo et al. 2011, Webb et al. 2011, Xu et al. 2012). In a study on grapevine phenology across many regions and varieties for 50 years conducted in Europe, it was observed that the phenological timing has advanced (6-18 days) with shorter intervals between events (414 days) (Jones et al. 2005b). Similarly, in Australia, Sadras and Petrie (2011b) observed an early maturation of Chardonnay, Shiraz and Cabernet Sauvignon due to higher 
temperatures. Interestingly, they associated the earlier harvest dates with an early onset of the ripening process rather than with a faster ripening. Sadras and Moran (2013) reported that the phenological shifts due to global warming were not linear, suggesting that other factors seemed to be modulating grapevine phenology. In this regard, Webb et al. (2012) attributed the detected trends in wine-grape earlier ripening to both warming and declines in soil water content. Webb et al. (2012) also suggested that other factors such as crop-yield reductions and evolving management practices have probably also contributed to earlier ripening. Other authors even suggested that despite climate change, in the Montsant region (Spain) the main changes in grape sugar content may be attributable to new trends in viticulture practices and changes in vineyard areas distribution (Lopez-Bustins et al. 2014).

The main impact of the advancement and compression of vine phenology is that grape-ripening is occurring under increasingly warm conditions. But it should also be considered that the predicted increase in spring and autumn temperatures will also lead to longer growing seasons than the current ones (Keller 2010a). The projected trends for climate change throughout the entire $21^{\text {st }}$ century (IPCC 2014) suggest major advances in vine phenology. For instance, Jones et al. (2005b) suggested that the phenological events' advance of 10-20 days in Europe under the scenario of warming $2.1^{\circ} \mathrm{C}$ by 2050 as compared to those of the last half century. Notwithstanding, there might be regional variations and different influences of climate change on vine phenology depending on the cultivated varieties. (Webb et al. 2007b) for example, prognosticated up to 45-day earlier harvests in Coonawarra (Australia) for Cabernet Sauvignon by 2050.

\subsubsection{Vine water requirements}

Climate change could potentially affect evapotranspiration (ET) in several complex ways which makes the quantification of overall changes in ET challenging (Anderson et al. 2008a). While air temperature is likely to increase ET, the effect of higher humidity and $\mathrm{CO}_{2}$ concentration could partially offset the temperature effect on ET (Snyder et al. 2011). For instance, (Anderson et al. 2008a) simulated the impacts of climate change on ET in California, reporting increments of $18.7 \%$ when considering only the air temperature increments $\left(3^{\circ} \mathrm{C}\right)$. However, when taking in account the predicted rises in air humidity and $\mathrm{CO}_{2}$ concentration, the ET increase estimation was lower (3.2\%). Overall, the predicted changes in Mediterranean climates indicate that increments in reference evapotranspiration (ETo ) will be moderate (Moratiel et al. 2010, Moratiel et al. 2011). 
Nonetheless, the higher $\mathrm{ET}_{0}$ coupled with the expected lower precipitation will significantly alter soil and plant water relations (Schultz 2016). Therefore, the risks associated with vine water stress are likely to increase in the near future (Duchêne and Schneider 2005, Ferrise et al. 2016, Gambetta 2016). Moreover, longer frost-free seasons and higher summer temperatures combined with drier conditions should also result in more severe vine water stress (Keller 2010a). Consequently, climate change will increase the need for vineyard irrigation, intensifying the competition for freshwater resources among other sectors (Hannah et al. 2013).

The total vine water consumption ranges from 300 to $700 \mathrm{~mm}$ per season depending on water availability and grapevine cultivars-environment interaction (Martorell et al. 2015, Medrano et al. 2015, Hochberg et al. 2017). This is generally higher than the water available in soil vineyards in Mediterranean climates. Thus, grapevines are used to facing some degree of water stress during the growing season (Sadras and Schultz 2012). Water shortage is probably the most dominant environmental constraint in current grape growing regions (Williams and Matthews 1990). Under a climate change scenario, water scarcity will be an even more limiting factor because vine growers will attempt to irrigate not only for aiming to reduce the increasing drought stress, but also to cool the grapes on the vine to reduce quality loss from heat stress (Myers et al. 2000). Moreover, in the long-term, irrigation practices might salinize vineyard soils due to the low-quality water employed. Mitigation practices of soil salinity include an excess of irrigation to leach salts down the soil profile, which in turn will increase water requirements.

Vine water requirements depend on canopy light interception (Williams and Ayars 2005, López-Urrea et al. 2012, Picón-Toro et al. 2012), and thus it is very sensitive to leaf area modifications. In future climate change scenarios, high temperatures may affect grapevine regulation of vegetative growth, thereby reducing it independently of water stress. This would reduce potential vine transpiration. Nonetheless, Greer and Weston (2010) did not observe any effects on leaf growth and stem extension under controlled day/night temperatures of 40/25 ${ }^{\circ} \mathrm{C}$ in Semillon. Moreover, the physiological responses to water stress under higher temperatures may vary according to the grapevine variety (Salón et al. 2004, Schultz 2016). The cultivar's regulatory mechanisms are diverse, including different control of stomatal conductance, aquaporin function, night-time water use, or respiration, among others (Lovisolo et al. 2010, Schultz and Stoll 2010). Fortunately, besides the greater knowledge on irrigation science, new technologies are currently available that can be used to improve water management, such as the use of remote sensing 
and thermal imagery technologies (Jones et al. 2002, Zarco-Tejada et al. 2005, Intrigliolo and Castel 2006, Intrigliolo and Castel 2007, Möller et al. 2007, Ortega-Farías et al. 2017).

\subsubsection{Vine performance}

Vine growth and grape production is strongly driven by water availability; thus, yield is decreased in response to water stress (Hardie and Considine 1976, Grimes and Williams 1990, Flexas and Medrano 2002). Climate change is expected to affect both vegetative growth and potential crop productivity (bud fertility, fruit set, berry weight). The different impacts of climate change on yields have been widely studied in many regions and crops, and there is no clear consensus on what the effects are (Bindi et al. 1996, Jones et al. 2005a, Palosuo et al. 2011, Moriondo et al. 2013). Final vine performance results from the interactive effects of water availability, temperature and air carbon dioxide concentration $\left(\left[\mathrm{CO}_{2}\right]\right)$ levels. For instance, both heat and water stress impair photosynthesis (Berry and Bjorkman 1980, Huglin and Schneider 1998, Flexas and Medrano 2002, Romero et al. $2010 \mathrm{~b}$ ), while increasing $\left[\mathrm{CO}_{2}\right]$ stimulates photosynthesis (Bindi et al. 2001, Santos et al. 2011, Wohlfahrt et al. 2017). Nonetheless, the increase of evaporation rates may reduce soil moisture over the long term in the Mediterranean region, and more especially in the Iberian Peninsula (Schultz 2000).

In grapevine production under Mediterranean climate, there is high confidence that water stress will be the major factor that will negatively affect biomass accumulation and harvestable yield, although this effect will be partly buffered by the increased photosynthesis and water-use efficiency (WUE) under higher $\mathrm{CO}_{2}$ conditions (Keller 2010a, Schultz and Stoll 2010, Gambetta 2016). In fact, the simultaneous increase in temperature and $\left[\mathrm{CO}_{2}\right]$ seems to have synergistic effects on photosynthesis (Sage and Kubien 2007), but this effect was recently reported to be transient (Salazar-Parra et al. 2012). The optimum temperature for vine photosynthesis is in the range of 20 to $30^{\circ} \mathrm{C}$, being reduced above $35^{\circ} \mathrm{C}$ due to heat stress (Kriedemann 1968, Schultz 2000, Keller 2010a). On the other hand, higher temperatures also enhance vine respiration, and this increases carbon losses at the plant level, possibly negatively-affecting yield (Schultz 2000). It is not surprising that 30 $75 \%$ of daily photosynthetic carbon gain is used in respiration (Field 2001, Escalona et al. 2012). This will decrease the amount of $\mathrm{CO}_{2}$ assimilated per unit of water transpired, known as instantaneous water-use efficiency. Moreover, $\left[\mathrm{CO}_{2}\right]$ alone seems to increase vine yield and improve WUE, but more comprehensive studies are needed to predict decreases in yield 
when increasing temperature and changes in solar radiation are considered simultaneously (Schultz 2000). Additionally, the longer vegetative period projected for grapevine could also affect the starch accumulation in the perennial structure of the vine. The higher availability of reserve carbohydrates might be beneficial for increasing yield, because of the stimulation of bud fertility in the consecutive season (Holzapfel et al. 2006).

Under the predicted context of water scarcity, improving vineyard WUE becomes crucial for the sustainability of viticulture in Mediterranean climates regions (Medrano et al. 2015). Nonetheless, WUE depends on complex interactions between environmental factors and physiological mechanisms which, from an agricultural point of view, will either reduce biomass production or the competitive ability (Jones 1992). For instance, Greer and Weston (2010) observed that vegetative growth was unaffected by high temperature whereas flowers completely abscised, resulting in null WUE in terms of grape production. Likewise, the percentage of fruit set as well as the bud fertility were markedly lessened by heat stress (Buttrose and Hale 1973, Kliewer 1977). Nevertheless, most of the studies on the temperature effect were based on average temperatures and did not consider the possible effect of short periods of extreme heat on yield components (Lobell et al. 2008, Grace et al. 2009, Sadras et al. 2013a).

Overall, the most pronounced warming is projected during summer, when grapevine growth takes place, and the lower rainfall and higher risk of heat waves during the growing season, suggests a gradual reduction in final yield (Giannakopoulos et al. 2009, Moriondo et al. 2011, Ferrise et al. 2016). For instance, in an analysis of the impact of temperature and precipitation on four white grape varieties conducted for two decades in northeast Spain, (Camps and Ramos 2012) estimated that yield may have been reduced by up to $30 \mathrm{~kg} / \mathrm{ha}$ for each millimetre increase in the estimated water deficit (crop evapotranspiration minus precipitation). Notwithstanding, (Sadras et al. 2017) performed 37 pair-wise yield comparisons in four varieties between vines heated with open-top chambers and ambient conditions, concluding that yield is unlikely to be affected under $2^{\circ} \mathrm{C}$ of warming in similar thermal regimes to the Barossa Valley (Australia). They stated that this demonstrated the resilience of the south Australian vineyards against the Paris Agreement' target setting of a long-term average temperature increase goal of well below 2 ${ }^{\circ}$ C. Sadras et al. (2017) also suggested that the focus to warming adaptation should be in fruit composition rather than in yield. 
In general, the grapevines' yield response to heat and water stress is to diminish berry size, markedly more when the stresses are suffered before veraison than after (Hale and Buttrose 1974, McCarthy et al. 2002, Intrigliolo et al. 2012) with consequences to the final vine yield (Fuentes et al. 2010, Gómez et al. 2011, Bonada et al. 2013). Berry size significantly affects fruit composition, either by increasing or decreasing fruit quality depending on the type of response to the stress (growth reduction, shrinkage or shrivel) and its timing (Santesteban et al. 2011a, Griesser et al. 2012, Gambetta 2016).

\subsubsection{Grape and wine composition}

Grape composition at harvest determines the aptitude for wine making. The main berry components are water, sugars, organic acids, anthocyanins, tannins and flavour and aroma components, but also some minerals such as potassium and calcium, aroma precursors or amino acids play an important role in determining the final wine composition (Keller 2010b). Fruit composition is the result of the ecological relationship between the vine (rootstock and scion) and the terroir (Castel et al. 2012). The last comprises the vine's whole natural environment and the combination of climatic factors such as light, temperature, solar radiation, soil water and nutritional content, and viticultural practices, which determines the crop load or the fruit maturity at harvest (Keller 2010b, Gladstones 2011).

Climatic variables play important roles in berry-ripening (Petrie and Sadras 2008, Sadras et al. 2013b). In cool and humid climates, climate changes may be beneficial for a proper balanced maturation (Keller 2010a, Hannah et al. 2013). However, in Mediterranean climates, where the ripening already occurs in warm and dry conditions, climate change might be detrimental for grape and wine composition (Wolfe et al. 2005, Webb et al. 2007a, Petrie and Sadras 2008, Mira de Orduña 2010). Wine grapes indeed are considered to be more vulnerable to climate change than other crops, considering that grape-ripening is not only affected by warming per se but also by the advancement of ripening to warmer periods of the season. Moreover, most of the grape's final product added value is provided by the desired wine style that depends on grape composition at harvest (Jones and Webb 2010). In fact, the variation in vintage quality is the result of the sensitivity to seasonal climate variability (Keller 2010a). Additionally, different varieties could respond differently to warmer environments. For instance, white cultivars appear to be less tolerant to warm conditions than red varieties (Dunn 2005). Therefore, climate change is a major issue for 
the wine industry, as wine typicity and its entire related viticultural heritage is being compromised (Jones et al. 2005a, Moriondo et al. 2013).

Under the warmer and dryer climatic conditions predicted for Mediterranean climate regions (IPCC 2014), grape sugar content is likely to increase while total acidity should decrease (Spayd et al. 2002, Anderson et al. 2008b, Salazar-Parra et al. 2010). Under elevated $\mathrm{CO}_{2}$ concentration, Bindi et al. (2001) observed, in the Sangiovese cultivar, that sugar concentration in berries also increased and acidity levels decreased. This in turn, could result in wines with higher alcohol levels and pH (Buttrose et al. 1971, Coombe 1987, Salón et al. 2005, Intrigliolo and Castel 2011). In fact, these effects have already been broadly observed in Europe, North America, and Australia (Schultz 2000, Duchêne and Schneider 2005, Schultz and Jones 2010, Sadras and Petrie 2011a, Webb et al. 2012).

The relationships of secondary metabolites (flavonoids or aroma compounds) with environmental changes are even more difficult to quantify than primary metabolites (sugars and organic acids) (Spayd et al. 2002, Mori et al. 2005, Schultz 2016). Overall, anthocyanin concentration is likely to decline in climate change scenarios (Spayd et al. 2002, Yamane et al. 2006), although the effects are different depending on the scenarios of water availability, temperature or $\left[\mathrm{CO}_{2}\right]$. Related to those changes, levels of UV-B in solar radiation will probably rise, which will alter secondary metabolites accumulation (flavonoids, amino acids and carotenoids) and might increase the risk for sunburn (Schultz 2000, Bergqvist et al. 2001, Guidoni et al. 2008).

Vine water status modulates flavonoid accumulation in the berry skin of red grape cultivars, leading to major compositional changes in the profile of the anthocyanin pigments (Sadras et al. 2007, Savoi et al. 2016). Water deficit could promote anthocyanin biosynthesis if water stress is not too severe (Castellarin et al. 2007b). In this regard, (Esteban et al. 2001) reported that the concentration of five anthocyanins in Tempranillo berries at harvest was higher in the irrigated plants as compared to rainfed vines. High temperature alone could delay or inhibit the synthesis of polyphenols (Kliewer and Schultz 1973, Iland et al. 2002, Mori et al. 2005). Furthermore, Mori et al. (2007) and Movahed et al. (2016) demonstrated that the decrease of anthocyanin accumulation under high temperature was the result of degradation processes besides biosynthesis inhibition. High daily mean temperature and/or low day-night thermal differences could also negatively-affect the wine aroma profile (Marais et al. 1999, Schultz 2000, Lebon 2002). 
The acceleration of primary metabolism and the delay or inhibition of the secondary one was defined as a decoupling effect by Sadras and Moran (2012). They stated that the anthocyanin-to-sugar ratio in berries was disrupted by high temperature, and so was the wines' colour-to-alcohol balance. This imbalance made more difficult the harvest date decision, because if the harvest is carried out at the usual grape sugar level, the low grape phenolic composition will not be suitable for high-quality wines. On the other hand, if harvest is delayed aiming at a more complete phenolic ripeness, wines will be too alcoholic with over-ripe aromas. In summary, a decrease in the colour-to-alcohol ratio and the modification of the varietal expression of aromas could result in low-quality wines (Mercurio et al. 2010, Mira de Orduña 2010). This indicates that the traditional wine styles resulting from a specific grape-ripening balance of the existing varieties will become progressively more difficult to obtain (Jones et al. 2005a).

In some more-extreme climate change scenarios air temperature may even become limiting for photosynthesis. Consequently, sugar accumulation could be compromised (Greer and Weston 2010). For instance, Sepúlveda et al. (1986) reported, for Chenin Blanc and Chardonnay vines exposed to $40^{\circ} \mathrm{C}$ during ripening, that heat stress significantly reduced the concentrations of glucose and fructose as compared to control vines. 


\subsection{Viticultural adaptation techniques to climate change}

The adaptation of viticulture techniques to climate change implies reducing the vineyard's vulnerability and exposure to predicted changes in the environmental conditions. Besides, most of the adaptation and mitigation responses are underpinned by common enabling factors (IPCC 2014). Thus, the mere maintenance of woody perennial crops ensures $\mathrm{CO}_{2}$ sequestration through photosynthesis and accumulation in their trunks. The interactions between climate change adaptation and mitigation may have a major influence on resilience and sustainable pathways (IPCC 2014). The viticultural adaptation techniques offer the possibility of modulating the interaction between environmental conditions and grapevines. For designing effective local adaptation techniques, it is critical to fully understand the future impacts of climate change on viticulture and wine typicity. Nevertheless, there are currently only a few studies that assess the interactive effects of the predicted simultaneous rise in temperature and $\left[\mathrm{CO}_{2}\right]$ under water deficit on grapevines (Keller 2010a). Also, most of studies were not carried out in field conditions under free air carbon dioxide enrichment (Salazar-Parra et al. 2010, Salazar-Parra et al. 2012, MartínezLüscher et al. 2015a, Martínez-Lüscher et al. 2016). Thus, the knowledge of the impacts of climate change on viticulture is still limited, and indeed it could vary among regions and grapevine cultivars. There is a lack of knowledge in the eco-physiological mechanisms and the genetic background underlying plant-environment interactions, although modelling may be a promising way for finding phenotypes that are better-adapted to future viticulture issues (Schultz and Stoll 2010, Vivin et al. 2017). Further interdisciplinary research is needed to enhance the resilience of viticultural systems under changing conditions (Keller 2010a, Nicholas and Durham 2012, Ollat et al. 2016). In addition, the success of the adaptation techniques to climate change strongly depend on the interaction of ecological and socio-economic factors (Lereboullet et al. 2013b).

A first possible adaptation strategy for facing climate change could be to relocate vineyards to cooler locations, in altitude or latitude (Schultz 2000, Jones et al. 2005b, Hannah et al. 2013, Ollat et al. 2016). But this is expensive and imply the abandoning of present viticultural regions and the changing of the traditional terroir characteristics that make up a specific wine style. In addition, this solution does neither consider the cultural and social part of winegrape cultivation nor the potential conflicts for land and water use generated in the new areas. In addition, other factors, mainly related to the soil's characteristics, also determine vine responses to climatic conditions (Schultz 2000, Coipel et al. 2006). 
A second strategy for vineyard adaptation could be changing the current grapevine cultivars for others more resilient or better-adapted to the projected climatic conditions in addition to exploring the intra-cultivar variability (Schultz 2000, Flexas et al. 2010, Hannah et al. 2013, Ollat et al. 2016). Notwithstanding, the phenotypic plasticity and the potential for acclimation seem to be cultivar-dependent (Sadras et al. 2007). This means that the plasticity of a trait, defined as the amount by which the expressions of individual characteristics of a genotype are changed by different environments, is genetically controlled (Bradshaw 1965, 2006). For instance, phenology could vary diversely for different cultivars over different climatic regions (plasticities of phenology). Until now, little information has been available on the suitability of different genotypes (cultivars, clones, rootstocks, and its interaction) in a range of environmental conditions (Keller 2010a). However, some interesting traits have already been identified among scions and rootstocks (Sepulveda and Kliewer 1986, Schultz 2003, Flexas et al. 2004, Clingeleffer and Emmanuelli 2006). Such traits are related to the acclimation to water scarcity and water salinity tolerance, or to high temperature and [ $\left.\mathrm{CO}_{2}\right]$ (Bota et al. 2001, Bota et al. 2016, Merli et al. 2016, Tortosa et al. 2016). Some authors have suggested the use of biotechnology and genetic engineering for breeding new varieties that are better adapted to climate change conditions (Iba 2002, Gambetta 2016). But the progress in genomics unravelling the function of grapevine genes (Terrier et al. 2005, Cramer et al. 2007, Deluc et al. 2007, Grimplet et al. 2007) seems to be not deep enough to cope with the challenges imposed by climate change.

Another adaptation option may result from changes in viticultural techniques, which would likely result in lower impacts on wine typicity and profitability than changing cultivars or relocating vineyards (Ollat et al. 2016). In this context, the role of a viticulturist's local knowledge is precious for identifying potential adaptations to climate change. Moreover, some drivers of the trend to earlier maturity have been identified among viticultural management practices, which implies that there is adaptation potential in our hands (Lopez-Bustins et al. 2014). The possible adaptation techniques are based on alleviating the undesired effects of water stress and higher temperatures. Among the possibilities, soil management, irrigation regulation, light interception modulation, the adjustment of the source-to-sink ratio or techniques that directly delay vine phenology, are worth mentioning (Duchêne and Schneider 2005, Keller 2010a, Connor et al. 2012) (Table 1). These techniques should be adjustable fit short-term variations in weather condition and long-term climate changes. To test the effectiveness of such cultural practices in 
Mediterranean climates, conducting field trials in specific sites under different clone/cultivar/rootstock combinations are crucial. However, in order to ensure the final uptake by the end-users, any viticultural adaptation techniques should ensure an ecologically- and economically-sustainable grapevine cultivation.

Table 1. Set of viticultural adaptation techniques to climate change and their possible effects.

\begin{tabular}{|c|c|}
\hline Viticultural adaptation techniques & Possible effects \\
\hline Soil management & Water and nutrients availability \\
\hline Regulated deficit irrigation & Improve WUE and grape composition \\
\hline Evaporative cooling systems & $\begin{array}{l}\text { Enhance berry growth and improve grape } \\
\text { composition }\end{array}$ \\
\hline Vineyard row's orientation & \multirow{2}{*}{$\begin{array}{l}\text { Modulate vineyard light interception and } \\
\text { thus vine water requirements and cluster } \\
\text { microclimate conditions }\end{array}$} \\
\hline Trellis system inclination & \\
\hline Shading nets utilization & \multirow{2}{*}{$\begin{array}{c}\text { Reduce solar radiation interception } \\
\text { (ameliorating vine water status and } \\
\text { alleviating heating) }\end{array}$} \\
\hline Particle films application & \\
\hline Shoot trimming & \multirow{2}{*}{$\begin{array}{c}\text { Modulate canopy shape regulating vine } \\
\text { vigour and vine water status and grape- } \\
\text { ripening }\end{array}$} \\
\hline Late leaf removal & \\
\hline Late pruning & \multirow{2}{*}{$\begin{array}{l}\text { Delay vine phenology postponing grape- } \\
\text { ripening to cooler periods }\end{array}$} \\
\hline Forcing bud growth & \\
\hline
\end{tabular}

\subsubsection{Soil management}

Soil characteristics affect vine root development and therefore the water and nutrients availability for the plant (Hidalgo 1999). Nonetheless, the plant's developmental response cannot be fully explained only in terms of soil water and nutrients availability, but it is also necessary to consider the plant's ability to access available soil resources (Passioura 2002). There are roots inhibitory signals that regulate the ecophysiology of conservative responses under restrictive soil conditions (too hard, limited volume, etc.). The nature of this behaviour is still under debate, but it may signify that a network of hormonal and other responses is involved in tuning the plant's growth and development to 
the environment (Passioura 2002). For these reasons, soil management can be a strategy for vineyard adaptation to water and heat stresses (Keller 2005).

Soils are also affected by climate change. In Mediterranean climates, increasing soil temperature leads to less available water, less biomass and soil organic matter content and hence to soil structure degradation (Lavee et al. 1998, Gambetta 2016, Schultz 2016). Such changes entail a decrease in water infiltration rates and an increase in soil erosion and aridity. Therefore, many regions of Mediterranean climate are threatened by desertification in the event of climate change (Lavee et al. 1998). Changing precipitation patterns and meteorological drought could aggravate the problem. In this context, the long-term sustainability of grapevine cultivation is at risk (Riches et al. 2013).

Optimising vineyard management under current and future climates requires better knowledge of the root system growth and functional responses to biotic and abiotic factors (Soar and Loveys 2007, Comas et al. 2010). For instance, it is known that vineyard floor mulch (Figure 8) reduces soil temperature and evaporation of soil water and thus the risk of root death, which is associated with both warmer soil temperatures and low soil moisture (Rogers et al. 1939, Bartsch 1987). Root death would restrict the plant's efficiency to obtain water and nutrients. In addition, mulch also alters the energy balance of a vineyard, which could alleviate the berry's heat stress (Bautista-Nazrala 2007). Compost mulches applications increase organic matter content and thus soil fertility, increase water retention capacity and provide good weed control (Ferrara et al. 2012). 


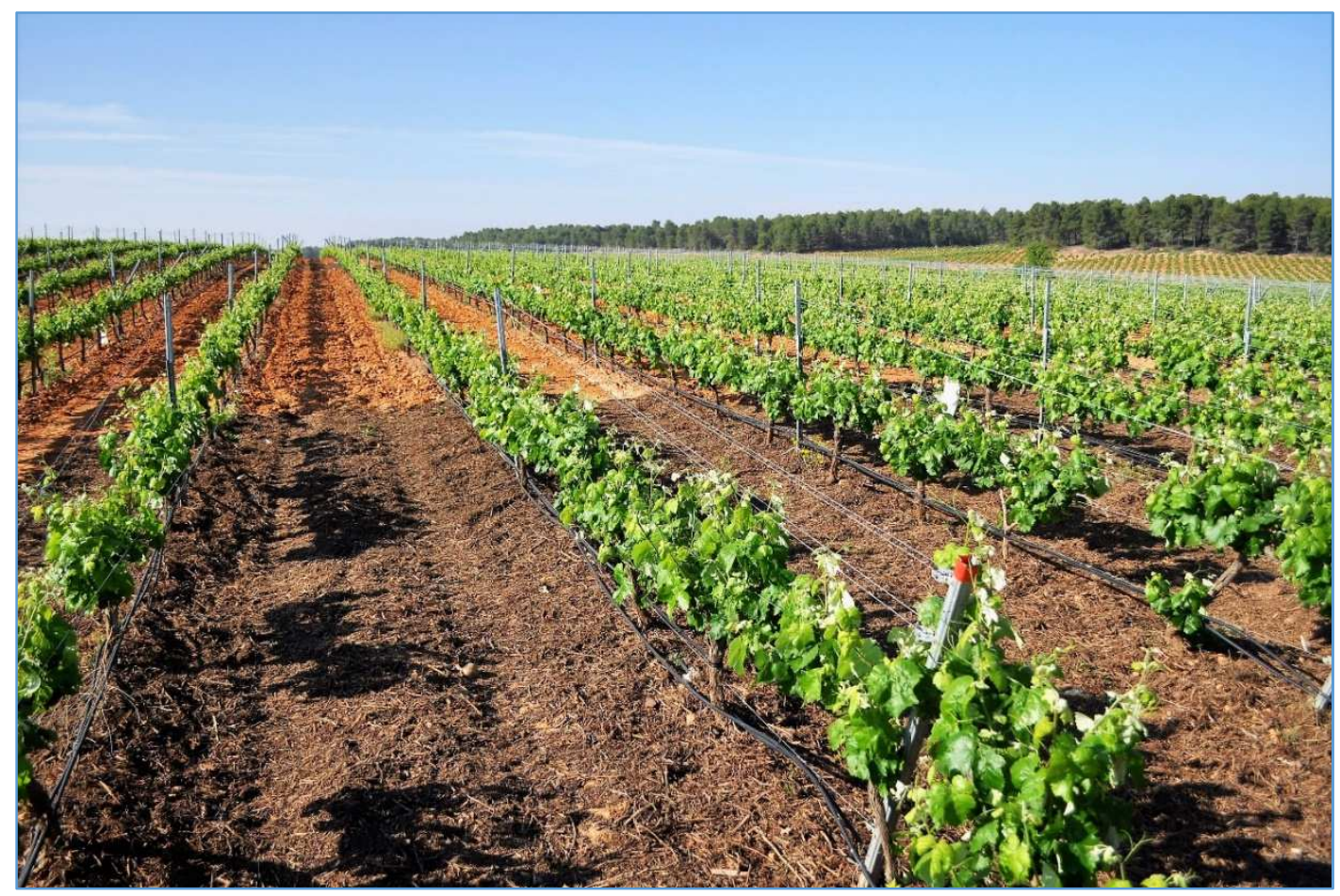

Figure 8. Pruned vine-wood mulch applied on a Bobal vineyard soil (Requena, Spain).

Another possible adaptation technique that could be used to mitigate the possible reduction in soil moisture and decay rates of organic matter could be the use of cover crops over winter (Schultz 2000). A properly-mowed and managed cover crop could likely reduce soil erosion and increase water and nutrient storage (Centinari et al. 2013). However, competition for soil water and nutrients from cover crops should not be neglected (Centinari et al. 2012). In humid and sub-humid climates, such as that of north-west Spain, cover crops can be useful for reducing vine vegetative growth without compromising yield and berry quality (Trigo-Córdoba et al. 2015). However, in dry area such as Southern Portugal, it can reduce yield without any benefits to grape quality (Lopes et al. 2011). Any soil management technique which promotes increases in soil water storage capacity and reductions of direct soil water loss could reduce the most-likely expected occurrence of vine water stress (Williams and Trout 2005, Intrigliolo and Castel 2006, Medrano et al. 2015). Alleviating soil dryness retards soil warming during the growing season, which avoids hastening vine growth and sugar accumulation in grapes (Zelleke and Kliewer 1979).

Soil management techniques increase soil organic matter content, and as it stores $\mathrm{CO}_{2}$, can therefore be suitable not only for adapting a vineyard to climate change, but also for mitigating it (Lal 2002, Morlat and Chaussod 2008). Soil carbon sequestration is truly a winwin strategy (Lal 2004). In fact, organic carbon in soils is the second-largest carbon pool on 
the surface of the Earth after the oceans (Batjes 1996, Swift 2001). Nevertheless, the beneficial effects of organic farming on global soil quality are not always evident (Coll et al. 2011).

\subsubsection{Water supply}

Most of the vineyards in Mediterranean climate regions are non-irrigated, thus introducing irrigation could partially compensate for the effects of climate change on the frequency and magnitude of vine water stress. Therefore, irrigation is likely to become a more common practice, although water scarcity restricts its use in most areas (Schultz 2000). In fact, at present, agriculture utilizes $70 \%$ of the global freshwater resources despite only $20 \%$ of the world's agricultural land surface being under irrigation (FAO 2011). Water shortage should promote the use of efficient technologies such as drip irrigation, usually combined with deficit irrigation techniques (Keller 2005). Notwithstanding, the salinityrelated impacts are expected to rise due to climate change, and thus irrigation management must consider a volume far in excess of field capacity for leaching salts (Connor et al. 2012, Fort et al. 2013).

Deficit irrigation consists on applying water rates to replace only a percentage of the potential vine evapotranspiration (Intrigliolo and Castel 2010). Water shortage can be applied either during the entire season or only during some phenological periods aiming to minimize decreases in yield and improve grape composition (McCarthy 2000, Greven et al. 2005). This technique is called regulated deficit irrigation (RDI), and its beneficial effects on grapevine adaptation to climate change can be summarised as: 1) improving water-use efficiency; 2) reducing heat stress; and/or 3) delaying grape ripening.

WUE is defined theoretically as the ratio between total plant dry matter production and total plant water consumption (Delrot et al. 2010). Maximizing WUE requires understanding the plasticity of vine development and root functionality under drought conditions (Comas et al. 2010). In this regard, deficit irrigation techniques aim to save water and control vegetative growth, avoiding the drastic reduction in yield while improving fruit composition (Bravdo et al. 1985, Chaves et al. 2007). In winegrape production, a moderate water deficit is known to usually improve wine composition (Jackson and Lombard 1993, Kennedy et al. 2002). However, the long-term effects of deficit irrigation strategies should be considered, due to the risk of a gradual reduction in yield and vegetative growth (Junquera et al. 2012). 
Water in vineyards has a cooling effect through air evaporation or vine transpiration and thus its application could reduce grapevine heat stress (Zarrouk et al. 2016). This can be achieved by means of irrigation (Kueppers et al. 2007, Lobell et al. 2008) or evaporative systems (Kliewer and Schultz 1973, Caravia et al. 2017). Additionally, irrigation can be used in certain varieties to slow down berry ripening rates, delaying ripening so that it occurs during cooler periods (Salón et al. 2005, Keller et al. 2008).

\subsubsection{Regulated deficit irrigation}

The regulated deficit irrigation (RDI) strategy allows enhancing the use of the water content stored in the root zone coming from precipitation. Previous reports stated that if the vine suffers water stress during the period from fruit set to veraison, fruit size will be sharply reduced, while if water stress is suffered from veraison to harvest, the berry reduction in size will be lower. However, post-veraison water deficit can reduce berry sugar accumulation and could delay ripening (McCarthy 1997, Girona et al. 2009, Intrigliolo and Castel 2010). Despite this, some authors reported that irrigation also led to a delay in obtaining the desirable sugar levels (Bravdo et al. 1985, Salón et al. 2005). For instance, the absence of water stress after veraison may promote competition for carbohydrates between secondary shoots and berries (Matthews and Anderson 1988, McCarthy 1997). In red grape cultivars, there is ample evidence that a moderate water deficit, depending on the timing of its application, may reduce yield slightly but may also be beneficial for some wine quality parameters. Nonetheless, in white grape cultivars there is less information available and results are not so conclusive, as metabolic responses to water deficit may vary according to the cultivar and fruit pigmentation (Deluc et al. 2009).

Phenolic compounds concentration in berries positively responds to a moderate water stress over the whole season, as long as certain physiological thresholds are not surpassed, due to increments in the skin-to-pulp ratio (Nadal and Arola 1995, Romero et al. 2010b, Intrigliolo and Castel 2011). But in fact, it has been reported that anthocyanin and tannin concentration can also increase with deficit irrigation aside from any effect related to berry size (Roby et al. 2004, Castellarin et al. 2007a). RDI also alters the cluster's microclimate, changing grape light exposure (Smart 1985). This may result in different effects on grape composition depending on the cultivar, training systems and the environmental conditions. Optimal irrigation strategies are difficult to generalize due to the complexity and heterogeneity of vineyards (Ortega-Farias et al. 2012). 


\subsubsection{Evaporative cooling systems}

The application of sprinklers as a cooling system can have a positive impact on grape growth and composition (Kliewer and Schultz 1973, Keller 2010a, Caravia et al. 2017). Kliewer and Schultz (1973) reported interesting results in three cultivars after sprinkling the whole canopy when the air temperature was above $30^{\circ} \mathrm{C}$. They observed increments in fruit size and delayed maturity in the sprinkled treatments compared to the un-sprinkled one. Berry composition showed higher levels of titratable acidity and malate, lower $\mathrm{pH}$, and increased coloration in the sprinkled grapes. Caravia et al. (2017) utilized an intra-sprinkler system at the cluster zone when air temperature was above $38^{\circ} \mathrm{C}$, which cooled the air inside the canopy by 3 to $5^{\circ} \mathrm{C}$. They reported increments in berry mass without differences in sugar content and a tendency for higher anthocyanin and phenolic compound contents per berry in the cooled treatments compared to the un-sprinkled ones. The reported results highlight the potential of evaporative cooling systems in adapting berry growth and grape composition to warmer climatic conditions. However, the large water supply needed for the application of the evaporative cooling practice might bring its widespread use into question, particularly in areas of water scarcity.

\subsubsection{Modulate light interception}

The vine canopy's photosynthetic activity is conditioned by many environmental and physiological factors (Zufferey et al. 2000). Vine water status, light intensity, air temperature and age of the leaves have a great impact on leaf gas exchange. Canopy management practices and training systems can modulate the amount of light intercepted by the vineyard (Schultz 1995, Hunter et al. 2016) and thus its productivity. Dry matter production and sugar accumulation in berries is a function of the photosynthetic capacity, which is linked to the absorption of photosynthetically active radiation (PAR) energy (Campos et al. 2017). The fraction of PAR absorbed by plants is determined by the canopy properties and the sun-canopy geometry. The vine PAR absorption during the season should be balanced with the water availability in order to avoid excessive water stress.

Both water and heat stress can be alleviated by regulating the sunlight intercepted by vineyards (Intrieri et al. 1998, Williams and Ayars 2005). Moreover, the modifications in light interception patterns greatly affect leaf and cluster microclimate conditions, affecting 
vine physiology and grape-ripening (Medrano et al. 2012). This could serve to mitigate excessive cluster sunlight exposure and overheating, reducing subsequent berry sunburn and shrivelling (Keller 2010a). In this sense, the modification of canopy light microclimate conditions must not unbalance the leaf area-to-fruit ratio, which optimizes yield and improves fruit composition (Reynolds and Vanden Heuvel 2009). For instance, adjusting row orientation in vertically shoot-positioned system (VSP) or leaning the canopy will not modify this ratio much, but it will modulate the amount and timing of light interception.

A better understanding of light interception effects in WUE, vine development and grape composition will help to fine tune adaptation techniques to climate change impacts in terms of canopy structure and management (Schultz and Stoll 2010).

\subsubsection{Row orientation}

Vineyard row orientation in a VSP system, given a vine's spacing, determines the timing and the amount of light intercepted on a daily and a seasonal basis. The theoretical PAR absorption by the canopy at the typical latitudes of Mediterranean climates would tend to be maximized in the north-south row direction and minimized in the east-west (Campos et al. 2017). These authors suggest that the greater PAR absorption during the morning promoted by the north-south orientation might imply a better physiological performance than the east-west in semi-arid environments. Nonetheless, if aridity continues increasing, the more severe water stress may limit vine physiology more than the reduction promoted by east-west in PAR absorption.

Sunlight interception also affects cluster microclimate conditions. In this concern, the expected increase in the frequency of extreme warmer days will undoubtedly tend to overheat berries, especially on the afternoon side of canopies (Spayd et al. 2002). This may require adaptations in row direction to avoid maximum sunlight interception during the hottest hours of the day, e.g. away from the prevailing north-south orientation (Keller 2010a).

\subsubsection{Trellis system inclination}

Vineyard trellis system inclination modifies light interception patterns and therefore influences vine water-use, vine performance and grape composition. For instance, Palliotti (2012) reported that a new closing Y-shaped training system was able to reduce the 
incidence of botrytis rot and improve grape and wine quality, while maintaining an adequate yield compared to a VSP system. This was explained by differences in the photosynthetic capacity and improvements in the cluster microclimate. Similarly, Smart (1988) and Mabrouk et al. (1997) found that a divided canopy enhanced grape composition. A more recent study assessing the effect of cluster position in berry composition showed that the berries located on the west side of the canopy had lower anthocyanin concentration due to higher cluster temperature (Zarrouk et al. 2016). These authors found an interaction between irrigation and high berry temperature on the control of berry ripening. Other authors reported the role played by light within the different training systems in the regulation of bud fruitfulness and thus grapevine yield (Dry 2000).

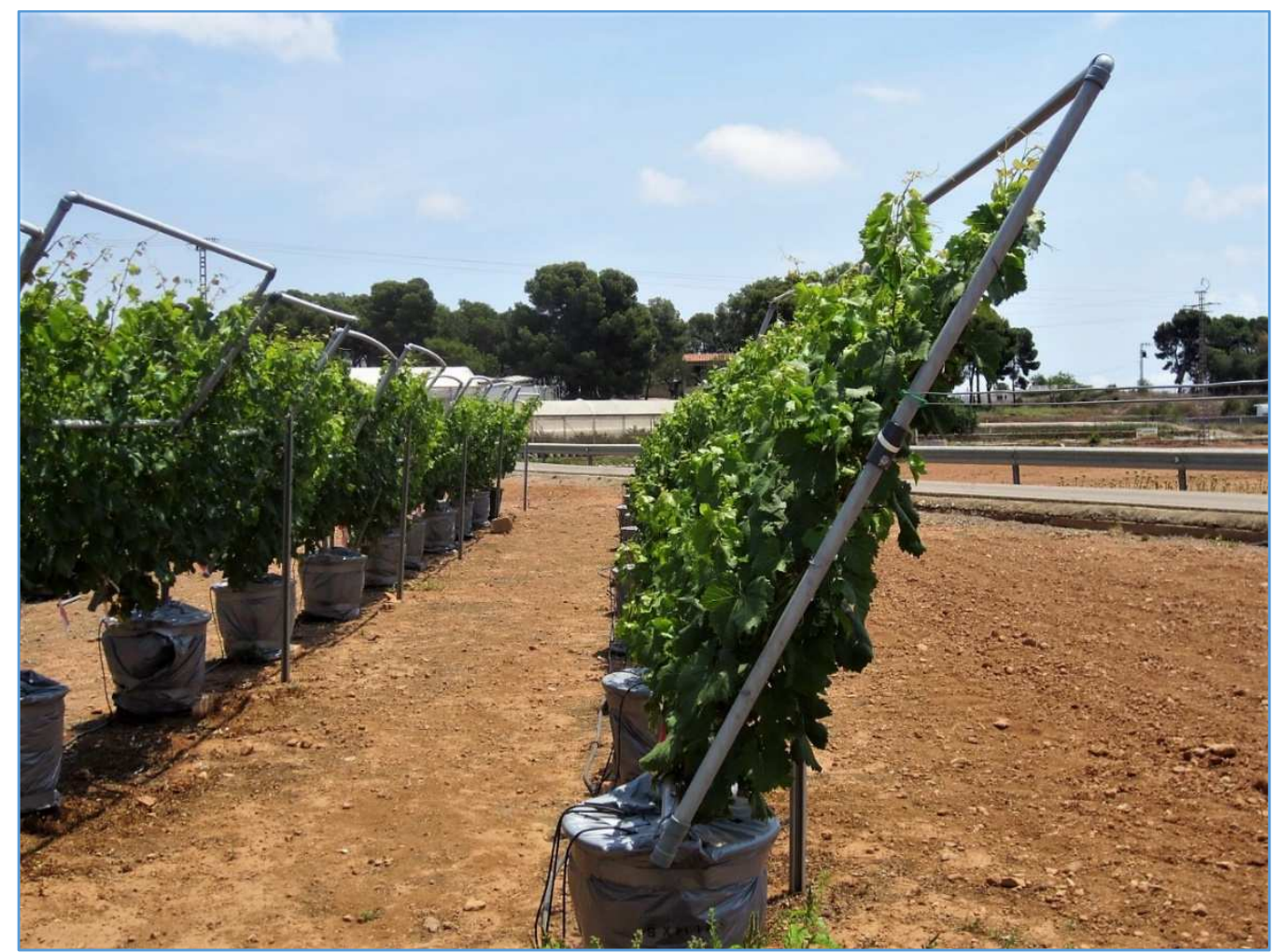

Figure 9. Leaning canopy of potted Verdejo vines (Moncada, Spain).

All this suggests modifying the traditional VSP system by leaning them (Figure 9) or moving toward free systems (without shoot positioning), namely sprawl, could be an interesting technique of adaptation to warmer conditions because of both its effect on vine water status and on cluster microclimate. 


\subsubsection{Shading nets utilization}

Shading canopies by means of overhead nets (Figure 10) allows reducing the incident radiation on the vines, decreasing canopy and cluster temperature (Greer and Weston 2010, Caravia et al. 2016). In addition, canopy shading might reduce vine photosynthesis capacity resulting in a phenology delay (Smart 1985). Some authors reported that artificial shading could be profitably used for delaying ripening process (Palliotti et al. 2014, Basile et al. 2015). In some studies, a delay in the rates of sugar accumulation per berry was observed, but grapes at harvest had a lower concentration of total soluble solids due to their higher water content (Caravia et al. 2016). This resulted in wines with lower alcohol content but with similar anthocyanins concentration. Caravia et al. (2016) concluded that shading nets applied from veraison to harvest could ameliorate the impact of heat stress through a significant reduction in berry cell death and in the loss of berry mass. Overall, shading nets promoted beneficial physiological effects such as higher chlorophyll concentration, higher net $\mathrm{CO}_{2}$ assimilation at saturating light, and better water status (Caravia et al. 2016). Moreover, Basile et al. (2015) found that early shading may be an efficient alternative practice for decreasing cluster compactness due to reductions in flower number per cluster, without significant changes in grape juice composition.

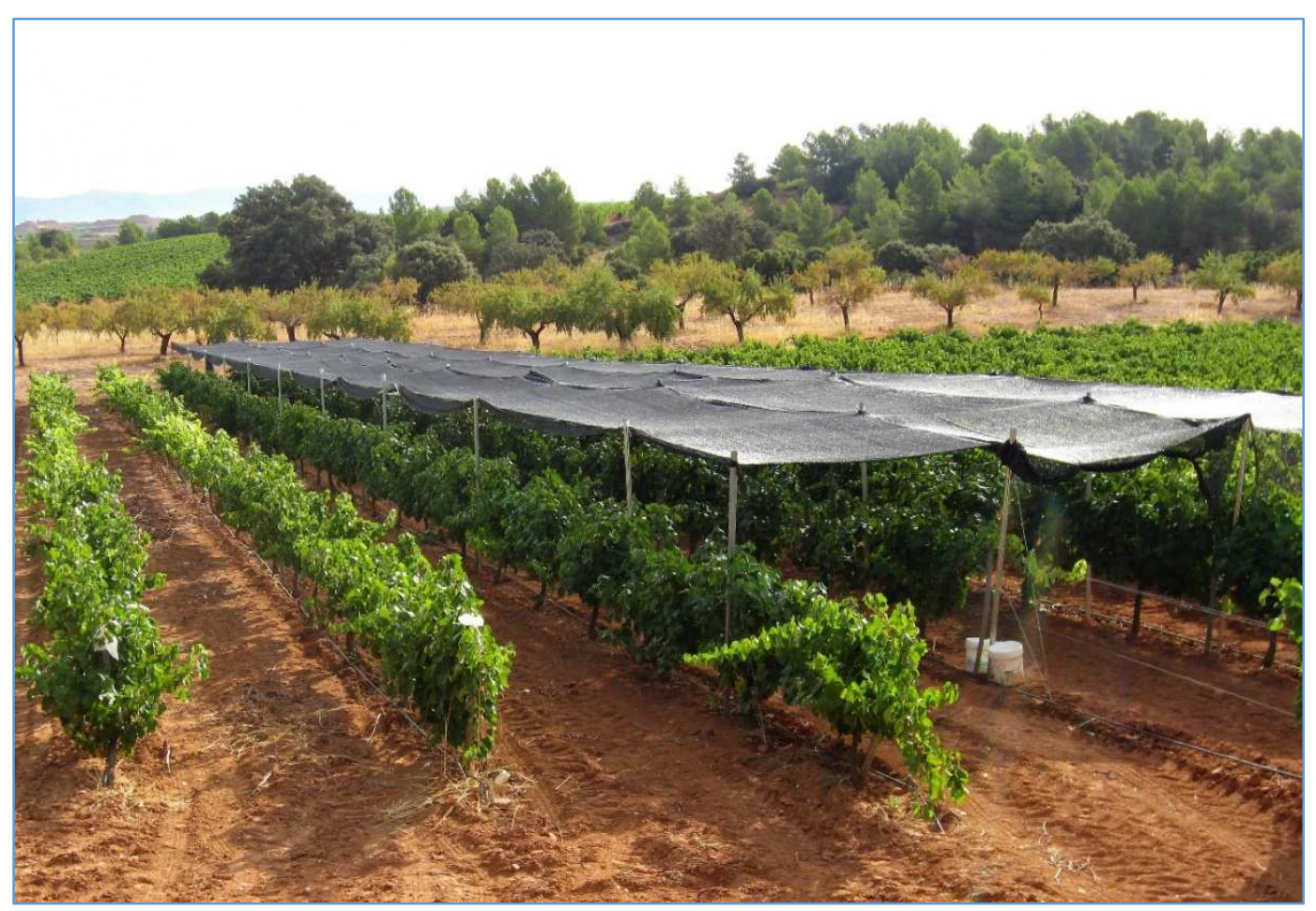

Figure 10. Shading nets over a Macabeo vineyard (Requena, Spain). 
In summary, in a climate change context, overhead shading seems to be an interesting adaptation technique that aims to delay ripening process, reduce heat stress and alleviate vine water stress. Notwithstanding, there is still a great lack of knowledge regarding the best timing and intensity of shading to achieve the target fruit composition for a given cultivar. The high cost of installation of this technique might, however, preclude its final application, at least in areas with low wine prices.

\subsubsection{Particle films application}

Particle films (PF) application consists on spraying canopies with a suspension of various kinds of clay, including kaolin, a white and inert clay mineral (Rosati 2007). The film formed over the vegetation protects it from heat and water stress, because of the reflection of part of the sunlight, increasing leaf albedo. In fact, the lower PAR absorption tends to reduce leaf stomatal conductance and photosynthesis without a clear effect at the whole canopy level (Rosati 2007, Shellie and King 2013a). However, Glenn et al. (2010) did find that the effects of kaolin application on leaf gas exchange induced an improvement in vine water status and enhanced WUE under non-limiting soil moisture conditions.

In most of the studies assessing PF in different crops, a tendency for enhancing grapevine performance due to berry enlargements and the reduction of cluster scorching, has been reported (Rosati 2007, Correia et al. 2015). Also, berry sunburn and other berry damage associated with excessive fruit exposure were reduced (Coniberti et al. 2013). PFassociated cooling effects can also affect berry ripening as well as grape and wine composition. For instance, Shellie and King (2013a, 2013b) demonstrated that foliar PF can facilitate the accumulation of anthocyanins in deficit-irrigated Malbec and Cabernet Sauvignon vines. Similarly, Song et al. (2012) observed increments in total anthocyanins in Merlot berries in response to PF. Furthermore, the kaolin application induced higher sensory scores for the wines made with Sauvignon blanc grapes due to better aromatic attributes (Coniberti et al. 2013). PF applications may be another technique for Mediterranean grapevine growing regions' adaptation to the expected warmer and drier conditions under elevated sunlight irradiance. Additionally, it can be used for pest management (Rosati 2007, Núñez-López et al. 2015). 


\subsubsection{Source-to-sink ratio limitation}

Vine leaves are the "source" of carbohydrates through photosynthesis, and the clusters are the "sinks" of the exported photoassimilates. For achieving correct berry ripening, the leaf area-to-fruit ratio should be balanced. According to Howell (2001) and Kliewer and Dokoozlian (2005), this balance must range from 0.7 or 0.8 to 1.2 or $1.4 \mathrm{~m}^{2} / \mathrm{kg}$, respectively. Below these thresholds, vines are considered unbalanced and thus incapable of reaching proper berry maturity. Other authors have suggested different vine balance indexes, such as the "Ravaz index" (Smart and Robinson 1991). This index is calculated by dividing the yield from the current harvest between the pruning weights from the following dormant season. This index should range from 5 to 10 for balanced vine in warm climates, whereas from 3 to 6 may be more appropriate for cool climates (Kliewer and Dokoozlian 2005).

Therefore, vineyards with leaf area-to-fruit ratios around 0.7 or 0.8 or above 10 in the Ravaz index will ripen slower. In this regard, a relatively simple strategy for delaying the occurrence of grape maturity during the cooler end of the season would be to markedly increase the vine crop load (Nemani et al. 2001). However, later studies have shown that the strategy of enhancing yield per se does not always slow down sugar accumulation and may also negatively-affect other wine quality parameters such as total polyphenols and anthocyanins (Poni et al. 2004, Kliewer and Dokoozlian 2005, Intrigliolo and Castel 2011). Moreover, while an increasing crop may be an attractive option for grape growers, it is unpopular among winemakers because of its influence on grape prices, and thus it is often forbidden by European laws (Keller 2010a).

Vegetative-to-fruit ratios can also be modulated by means of the training systems and canopy management practices, or through cluster thinning. For achieving the target grape maturity, the vine balance should be fine-tuned for the specific cultivar and wine style, considering the edaphic and environmental conditions. Hence, since climate change is altering vine physiology, it is unbalancing the traditional equilibrium indexes, and therefore new insights for adapting the indexes are needed. In this concern, techniques which reduce leaf area during the ripening period such as shoot trimming or leaf removal could help to displace ripening to dates of lower day length and thus cooler temperatures. 


\subsubsection{Shoot trimming}

Shoot trimming consists on pruning shoots tips during the growing season to maintain the canopy shape containing vine vigour. Leaves located on the apical two-third of the canopy are the most photosynthetically-active and its removal can significantly reduce the vine's photosynthetic capacity (Poni et al. 1994). The effects of shoot trimming on grape quality are closely associated to the number of leaves retained on the shoot and the timing of its application. Aiming to delay the ripening process, the phenological stage for applying the trimming must be around veraison (Filippetti et al. 2015, Parker et al. 2015, Santesteban et al. 2017). Adjusting the adequate trimming intensity and timing is critical for designing a suitable strategy of post-veraison summer pruning to decrease berry sugar accumulation rates (Caccavello et al. 2017).

Filippetti et al. (2015) reported that a late season severe trimming just after veraison (8 main leaves retained) was effective in delaying berry sugar accumulation without impairing the concentration of anthocyanins and seed tannins. Similarly, Martinez de Toda et al. (2015) applied shoot trimming in Grenache and Tempranillo varieties and increased anthocyanin concentration in berries at the same sugar level than the non-trimming treatments. Moreover, in Sangiovese, Bondada et al. (2016) have shown that post-veraison shoot trimming can be used for reducing cluster compactness without compromising overall fruit quality. The delay in berry ripening due to shoot trimming could even be enhanced if the lateral shoots growth was stimulated after its application. Vegetative growth could then compete for the photoassimilates with the berries (Keller et al. 2015, Santesteban et al. 2017).

\subsubsection{Late leaf removal}

Leaf removal consists on eliminating leaves from the shoots, both in the cluster zone or above. Traditionally it has been used for improving light penetration within the canopy and airflow around the clusters, leading to enhanced berry and phenolic composition with better disease control (Smart et al. 1990, Jackson and Lombard 1993, Reynolds and Wardle 1993, Belancic et al. 1997, Diago et al. 2010). However, aiming to mitigate the effects of heat and water stress and delay the accumulation of berry sugars, defoliation can be also performed around veraison in the apical area to the cluster zone (Lanari et al. 2013, Palliotti et al. 2013b). 
Several studies in many cultivars have shown that ripening can be postponed after defoliation, but with contradictory results in terms of grape composition (Stoll et al. 2010, Poni et al. 2013, Intrieri et al. 2017). More effort is needed in order to unravel the cultivardependent interactions between late leaf removal and the environmental conditions.

\subsubsection{Delaying vine phenology}

It is well known that winter pruning applied later in the season, at the swelling bud stage, is effective in diminishing the risk of spring frost damage because it delays the budbreak date by a few days (Palliotti et al. 2014). Therefore, it is possible to postpone the entire phenological cycle as an alternative to moving the ripening process to cooler periods (Parkin and Turkington 1980, Friend and Trought 2007). With this goal, two possible adaptation techniques to climate change are described, "late pruning" (Frioni et al. 2016, Gatti et al. 2016) and "forcing bud growth" (Gu et al. 2012).

\subsubsection{1. $\quad$ Late pruning}

Delaying pruning until shoot apical nodes initiate bud-break, postpones the development of basal nodes (Figure 11) and all the subsequent phenological stages of the vine (Martin and Dunn 2000, Friend 2005). The physiological basis of this technique is the apical dominance of distal buds of the canes (Keller et al. 2015).

Previous studies related with late pruning reported delays in bud-break ranging from 24 and 32 days in Carignan and Grenache (Vergnes 1981) to 5 days for Cabernet Sauvignon (Martin and Dunn 2000). In cool regions, late pruning can be performed to improve yield, avoiding fruit set failure reductions (Bouard 1967, Vergnes 1981, Friend and Trought 2007). Nonetheless, under cool conditions, late pruning could lead to unripen fruits because of the short growing season. In warm climates, yield response to the late pruning technique tends to be limited compared with normal (winter) pruning. This can be attributed to the depletion of reserves mobilized firstly for bud-break of distal buds, which impairs the differentiation of flower organs inside the bud (Lebon et al. 2008). Nevertheless, late pruning has the potential of improving grape composition, by increasing titratable acidity, total anthocyanins and phenolic concentrations (Parkin and Turkington 1980, Frioni et al. 2016). Occasionally, the delay provoked in bud-break, can be offset at harvest because of the lower crop load of the late pruned vines (Gatti et al. 2016). This would prevent ripening 
during cooler periods, but could achieve similar effects on grape composition as cluster thinning.

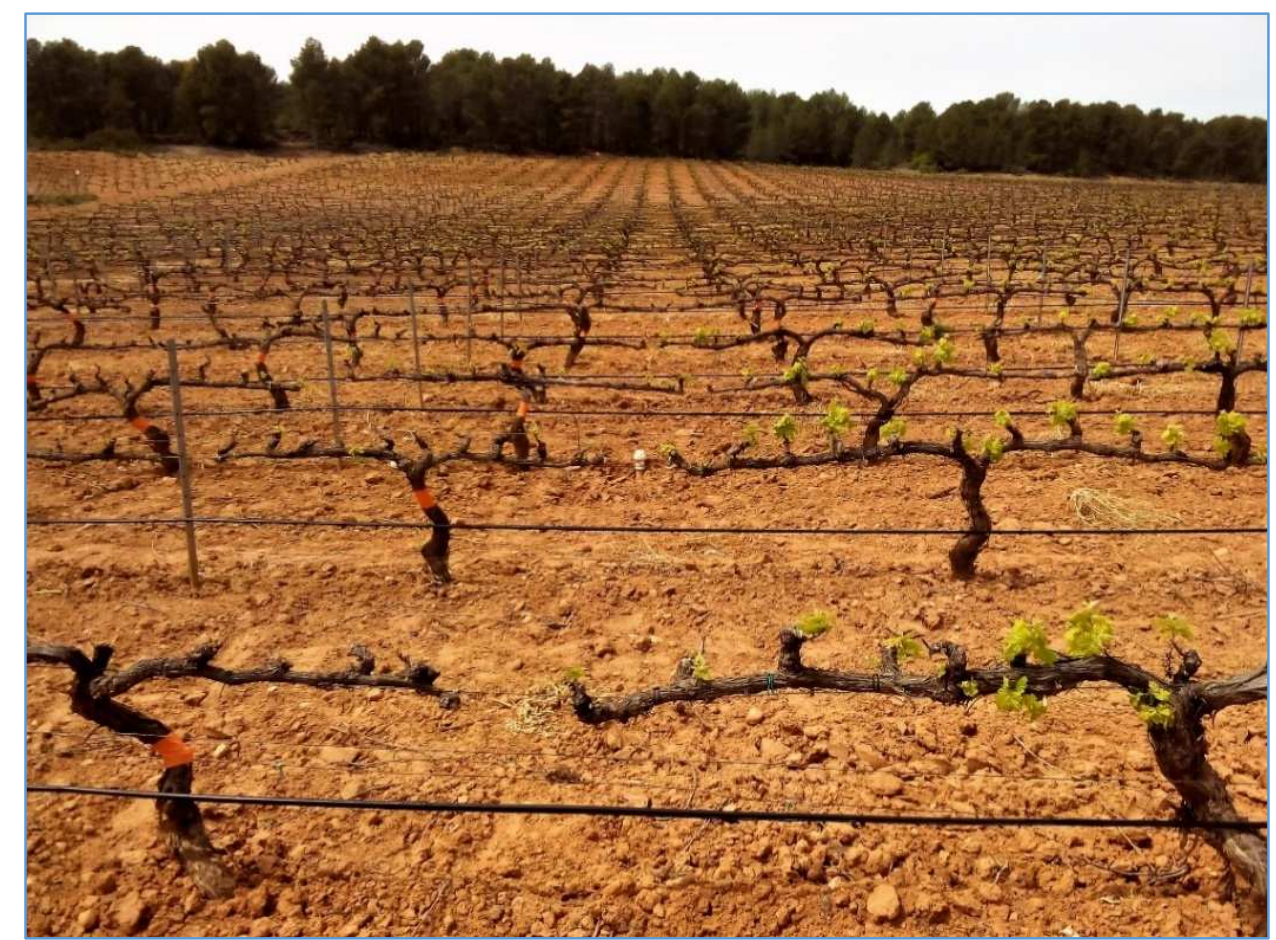

Figure 11. Late pruned Tempranillo vines (left) and winter pruned (right) (Requena, Spain).

Overall, late pruning seems to be a quite promising technique for delaying berryripening, however, further studies are needed to clarify its repeatability and consistency of its effects under an array of cultivars, environments and pruning dates. The best compromise between yield limitation and grape and wine composition need to be found. Moreover, the possible carry-over effects on subsequent yields needs to be unravelled.

\subsubsection{Forcing bud growth}

This technique is based on the grapevines' double-pruning, applied in tropical and subtropical climates as a management strategy for harvesting twice per year (Favero et al. 2011, Chen et al. 2017). Under Mediterranean-like climate conditions, as the growing season is shorter, only one fully-ripen crop per season can be achieved (Gu et al. 2012). Forcing consists on green cane pruning, removing all the non-perennial parts (laterals, leaves, clusters), aiming to force the growth of the primary buds formed for the subsequent season (Figure 12). It has to be applied between flowering and veraison in order to have buds that are sufficiently differentiated but not yet in dormancy (Keller et al. 2015). By 
forcing, the growing season starts again, resulting in ripening occurring during autumn. Gu et al. (2012) tested this technique in Cabernet Sauvignon and observed that depending on the timing of forcing application, yield could be greatly reduced or not affected compared to unforced vines. But interestingly, grapes from forced vines showed higher acidities, lower $\mathrm{pH}$ and much higher phenolic content as compared to the berries from the unforced vines.

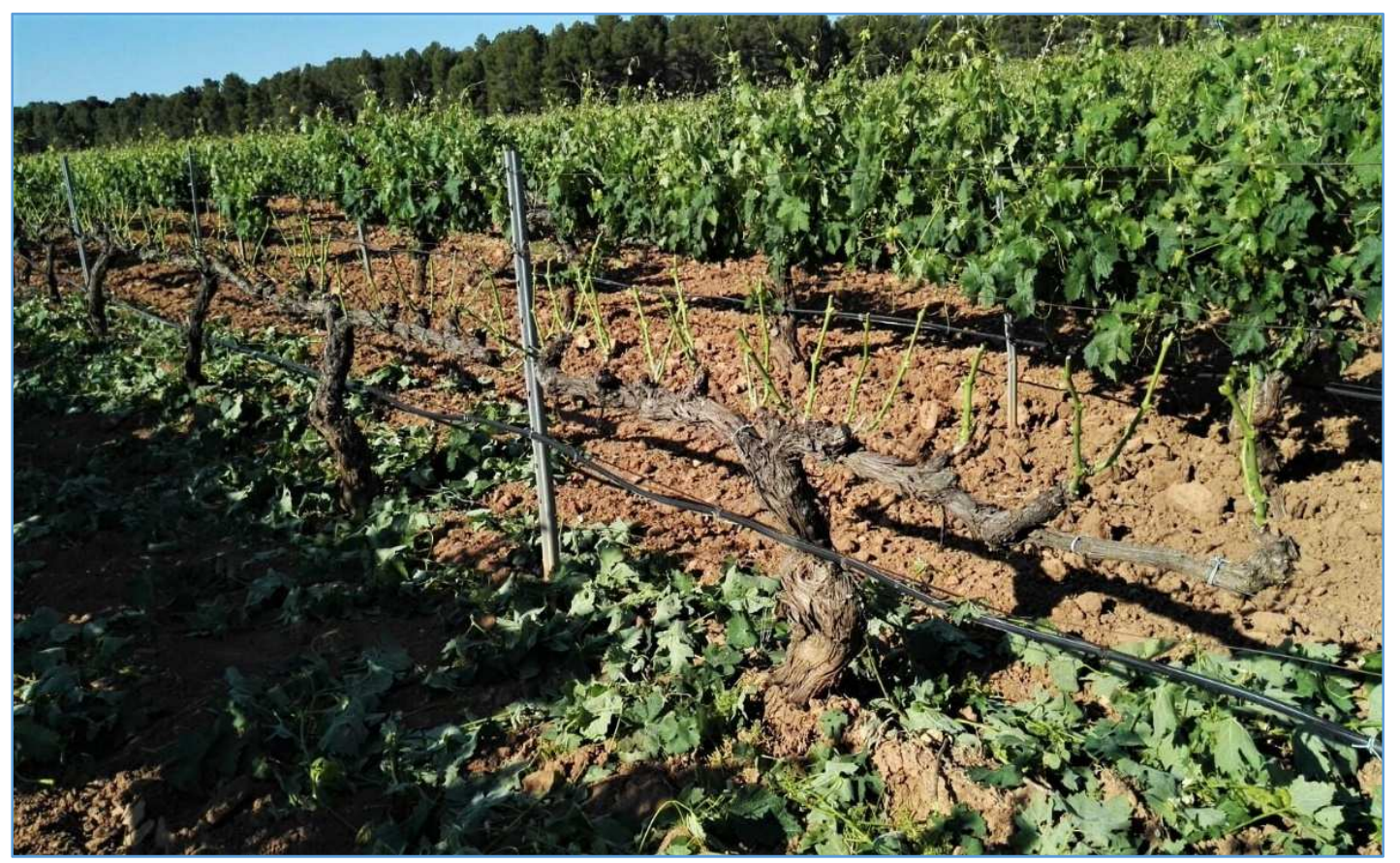

Figure 12. Double pruning to force bud growth in Tempranillo vines (Requena, Spain).

Overall, a further postponement of the grape-ripening process seems a quite promising tool for addressing the detrimental effects of high temperatures on fruit and wine quality in warmer regions. However, the positive results in terms of grape composition must be sensed in the taste results of the resultant wines, as large aromatic differences in wine typicity are expected under such changes in the weather conditions during ripening. Moreover, this technique should be fine-tuned in terms of the timing and number of retained buds in several cultivars and the carry-over effects assessed. In addition, agronomical practices and water and fertilizers applications must be adjusted to the resultant changes in the phenology of the crop. 


\subsection{Objectives}

The general goal of this $\mathrm{PhD}$ thesis is to assess the usefulness of several field practices related to the irrigation regime, canopy management and vineyard design for adapting Mediterranean viticulture to future climate change scenarios of increased water scarcity and warmer ambient temperature conditions. In this sense, in order to cope with water scarcity, the objective was to explore the possibility of increasing water-use efficiency (WUE) defined as the ratio between yield and evapotranspiration, the last estimated as rainfall plus irrigation. In parallel, to face global warming, the aim was to delay graperipening, aiming to alleviate the potential detrimental effects of high temperatures on grape composition. Under this general context, the specific aims for this $\mathrm{PhD}$ thesis were:

a) The agronomical assessment of regulated deficit irrigation techniques (RDI), to test the plant water stress threshold values (water stress integral, $S_{\Psi}$ ) in order to improve WUE and grape composition;

b) To determine the best vineyard exposure to solar radiation for enhancing WUE and grape composition by means of modifying the sunlight interception patterns through different vertical hedgerow system orientations;

c) To evaluate the mitigation potential of late leaf removal in coupling technological and phenolic ripeness in red varieties with oenological vocation by postponing grape-ripening towards relatively cooler periods.

Three field experiments were carried out in order to test the following hypothesis:

1) Both WUE and grape composition can be enhanced by deficit irrigation applied at different phenological periods. An irrigation shortage before veraison, inducing a moderate vine water stress, can reduce vegetative growth while minimizing yield decreases. On the other hand, applying a moderate water stress during the postveraison phase, should concentrate grape metabolites responsible of defining berry quality for winemaking purposes. In addition, a sustained deficit irrigation strategy was compared to full irrigation. These hypotheses were tested in a three-season RDI experiment carried out in a commercial vineyard of Vitis vinifera cv. 'Muscat of Alexandria'.

2) Vine transpiration can be decreased and WUE increased by east-west vineyard row's orientation in comparison to the north-south one, due to the influence of the amount 
and timing of solar radiation intercepted by the canopy on vine transpiration. Potted Vitis vinifera cvs. 'Verdejo' and 'Bobal' vines planted in either north-south or east-west vineyard row orientation were compared for three seasons.

3) Reducing leaf area-to-fruit ratio at the beginning of ripening by defoliation carried out at veraison could delay grape-ripening rates. As a result, berries can ripen under less warm conditions, alleviating grape heat stress and the resultant detrimental effects on grape composition. A two-season experiment was carried out in a commercial vineyard of Vitis vinifera cvs. 'Bobal' and 'Tempranillo' under different watering regimes. 


\section{Chapter II}

\section{DEFICIT IRRIGATION FOR IMPROVING}

\section{WATER-USE EFFICIENCY AND GRAPE COMPOSITION IN VITIS VINIFERA L. CV. MUSCAT OF ALEXANDRIA}

This chapter is an adaptation of:

Buesa, I., Pérez, D., Castel, J., Intrigliolo, D. S. and Castel, J. R. (2017). Effect of deficit irrigation on vine performance and grape composition of Vitis vinifera L. cv. Muscat of Alexandria. Australian Journal of Grape and Wine Research 23(2): 251-259.

(https://doi.org/10.1111/ajgw.12280) 


\section{DEFICIT IRRIGATION FOR IMPROVING WATER-USE EFFICIENCY AND GRAPE COMPOSITION IN VITIS VINIFERA L. CV. MUSCAT OF ALEXANDRIA}

\section{Introduction}

Irrigation of crops tends to be a standard practice in Mediterranean viticulture as an effective means of regulating the water status of grapevines, and it is being favoured by the impact of global warming (Jones and Davis 2000, Petrie and Sadras 2008, Schultz and Jones 2010). Furthermore, global climate models predict higher evapotranspiration demands and longer drought periods in eastern Spain in the near future (IPCC 2012). Therefore, application of supplemental irrigation, if available, could mitigate the possible negative effects of climate change on vine productivity and fruit ripening (Sadras and Moran 2012). But in the context of water scarcity, an interesting strategy could be the application of deficit irrigation (DI) to improve water productivity while saving water (Bravdo et al. 1985, Intrigliolo and Castel 2010), as ensuring potential vine evapotranspiration may reduce wine quality (Williams and Matthews 1990). Thus, regulated deficit irrigation (RDI), which is based on reducing water supply at certain phenological stages, may lead to greater water-use efficiency while improving grape quality (McCarthy 2000).

The effect of RDI strategies in white grape cultivars was examined applied prior to or after veraison on Vitis vinifera cv. Sauvignon Blanc in the Columbia Valley (USA) for 6 years (Wample and Smithyman 2002). Their results indicated that RDI prior to veraison reduced shoot growth as well as pruning mass, while full irrigation prior to veraison resulted in excessive shoot growth. Thus, RDI applied after veraison to vines with large canopies resulted in greater plant water stress. Although there was some reduction in berry mass, yield was not always significantly reduced. Total acidity (TA) was increased by preveraison RDI as compared to post-veraison RDI, while TSS remained similar after both treatments. Also in Sauvignon Blanc grapes, but in a wetter region (Marlborough, New 
Zealand), Greven et al. (2005) found that during the 2 years of RDI, leaf area (LA) was reduced but none of the yield or quality parameters were affected. In Chardonnay grapevines grown under field conditions in Chile (Ferreyra et al. 2003), water deficit decreased shoot growth and also berry diameter, consequently reducing yield if applied from budburst to veraison. These authors reported that water stress did not increase the wine TA, concentration of phenolic substances and flavour intensity of wine, displaying a different behaviour than that observed in some red grape cultivars (Bravdo et al. 1985, Matthews and Anderson 1988). Similarly, the influence of irrigation over a 4-year period in an Ontario Chardonnay vineyard in a cool and humid climate was found to increase yield in comparison to that of non-irrigation, as the plants produced larger berries, higher TA and greater desirable wine sensory attributes without any decrease in TSS (Reynolds et al. 2007). In a comparable trial in the Napa Valley, California, however, Williams (2014) found that TSS of Chardonnay grapes decreased as applied water increased. Also, other advantages of irrigation were found in the temperate climate of northern Spain when compared to rainfed vines (Cancela et al. 2016). In this trial, two local white grape cultivars, Godello and Albariño, showed a slight increase in yield in some seasons without a difference in must composition. In the more arid climate of southern Spain, López et al. (2007) found that irrigation applied from fruitset until harvest, compared to that of non-irrigation, increased pruning mass, yield, berry size and induced higher TA with no effect on TSS accumulation on five white grape cultivars, Baladí, Airén, Montepila, Muscat Blanc à Petit Grains and Pedro Ximénez.

Muscat of Alexandria, a white grape, is a member of the Muscat family of $V$. vinifera, and has been characterised by Regina and Carbonneau (1996) as a cultivar that is adapted to water deficit conditions, due to the low sensitivity of its carbon assimilation rate to water stress. It is cultivated world-wide for tablegrape and raisin production and crushed into wine. In Spain, for instance, it is used to make fortified wines ('mistella'). In field-grown 
Muscat of Alexandria grafted onto 1103 Paulsen, the effect of different irrigation techniques [namely DI (deficit irrigation) and partial root-zone drying (PRD)] were studied in southern Portugal, concluding that $50 \%$ of $\mathrm{ET}_{\mathrm{c}}$ was sufficient to guarantee the entire 'Muscatel' yield potential (de Souza et al. 2003, dos Santos et al. 2003, 2007). Furthermore, they found that PRD improved vine water status due to a higher inhibition of vegetative growth and a subtly greater regulation of stomatal conductance $\left(\mathrm{g}_{\mathrm{s}}\right)$ in comparison to DI. Therefore, considering the high physiological adaptation to water stress conditions of this cultivar, we decided to evaluate the vine response to DI strategies applied during different phenological periods (RDI), as this irrigation strategy is more easily transferable to farmers as compared to PRD.

In this context, the aim of our work was to gain knowledge on the effect of RDI strategies on vine water status, productivity, ripening processes and grape composition of Muscat of Alexandria grapevines grown for white wine production. More specifically, the response to seasonal water deficit was investigated in order to define the most appropriate phenological stage for the applying of water deficit in eastern Spain.

\section{Material and methods}

Vineyard site and experimental design

The experiment was undertaken during the 2012-2014 seasons in a commercial Muscat of Alexandria vineyard (V. vinifera L.) located near Vilamarxant $\left(39^{\circ} 33^{\prime} \mathrm{N}, 0^{\circ} 42^{\prime} \mathrm{W}\right.$, elevation 197 m), in Valencia, Spain. The vineyard was planted in 1996 with 161-49C rootstock at a spacing of $2.75 \times 1.8 \mathrm{~m}$ (2020 vines/ha). This rootstock ( . riparia $\mathrm{x} V$. berlandieri) is well adapted to calcareous clay soils and is highly sensitive to salinity; it has medium vigour, steady yield and promotes early ripening (Chomé Fuster et al. 2003). Vines were winter pruned to a 20 bud count per vine on a bilateral cordon de Royat and trained to a vertical trellis system oriented north $23^{\circ}$ west direction. The canopy management 
practices conducted by the vineyard owner were those common to the area (Figure 13). These included manual shoot thinning before the onset of flowering, no shoot hedging and basal leaf removal on the east side of the vine when veraison (berry softening) began. Leaves were removed to prevent grape fungus diseases by favouring air flow through clusters (Figure 14), but also to increase the aromatic composition of the fruit as a result of sun exposure (Belancic et al. 1997). Canopy height and width were on average about 1.1 and $0.40 \mathrm{~m}$, respectively.

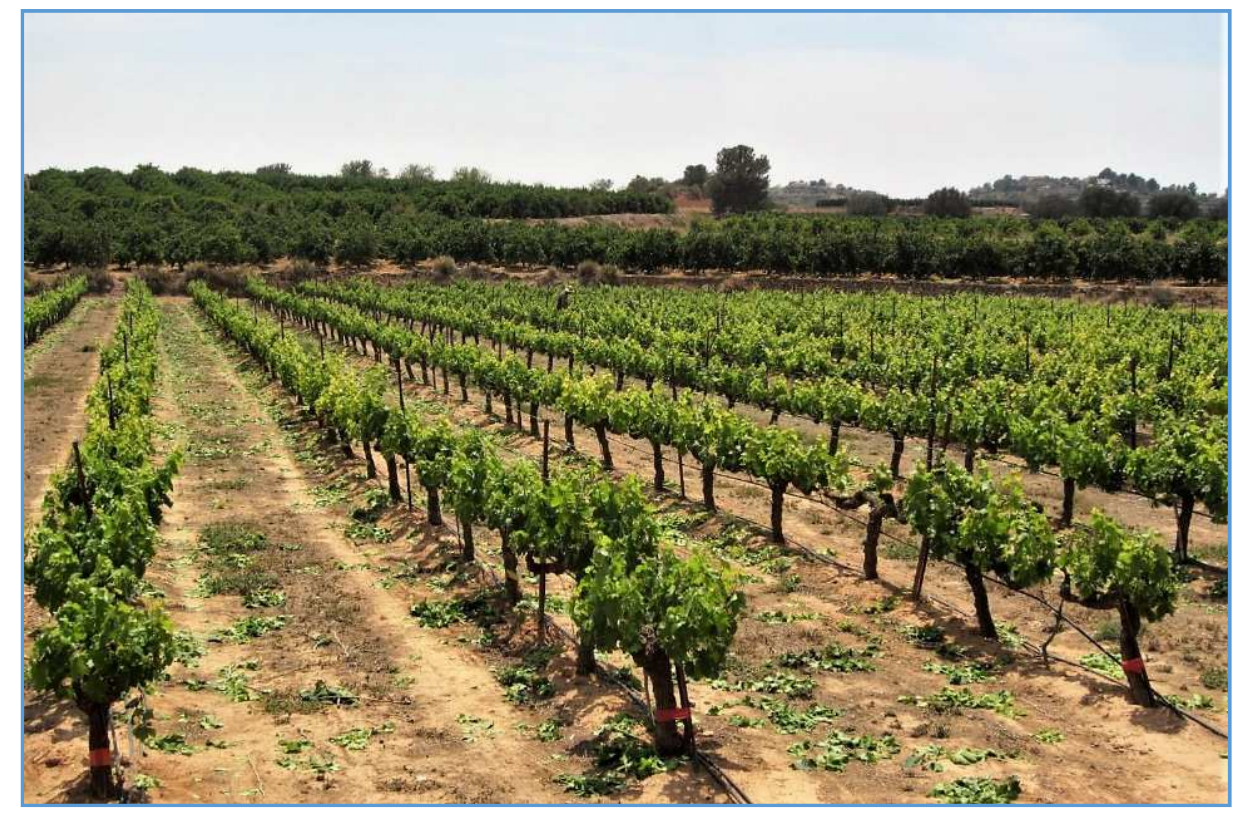

Figure 13. A general view of the Muscat of Alexandria vineyard in 2014. The photograph was taken just after shoot thinning application.

The soil at the site was loam textured (56.5\% sand, $32.0 \%$ silt and $11.5 \%$ clay), highly calcareous and of medium fertility. The soil had a deep profile (1.5-2 m), available water capacity was about $200 \mathrm{~mm} / \mathrm{m}$ and bulk density ranged from 1.26 to $1.47 \mathrm{t} / \mathrm{m}^{3}$. The soil was not tilled during the experiment; spontaneous weeds between rows were controlled by mowing twice a year if necessary and by herbicide applications in the vine row.

Weather conditions were recorded at an automated meteorological station $1.4 \mathrm{~km}$ from the plot. Reference evapotranspiration $\left(\mathrm{ET}_{0}\right)$ was calculated with the Penman- 
Monteith formula (Allen et al. 1998) and growing degree days (GDD) were computed as the sum of the average daily temperature above $10^{\circ} \mathrm{C}$ from 1 April until harvest (Amerine and Winkler 1944). Vapour pressure deficit was calculated following Buck (1981). Rainfall was measured with an automated rain collector located within the experimental vineyard.

Budburst for Muscat of Alexandria in this area occurs usually by mid-April and flowering by early June; veraison is reached by early August and harvest occurs during September. The climate is typical Mediterranean and semi-arid, with an average annual rainfall of $422 \mathrm{~mm}$, of which about 55\% falls during the dormant phase. According to the climatic classification system for grapegrowing regions proposed by Tonietto and Carbonneau (2004), the bioclimatic indices for our experimental area showed a warm climate, with temperate nights while being moderately dry.

\section{Irrigation treatments}

The vineyard has been drip irrigated since 2005 and at the beginning of 2012 the irrigation system was modified in order to impose four treatments: (i) Control, irrigated at $100 \%$ of the crop evapotranspiration $\left(\mathrm{ET}_{\mathrm{c}}\right)$, based on crop coefficient values quantified for Tempranillo in a similar climate by López-Urrea et al. (2012) and Picón-Toro et al. (2012), which varied according to the phenological stage and the expected pattern of leaf area development until leaf fall; and additionally, measurement of soil moisture content and plant water status was also used to modify the irrigation scheduling in order to maintain vines under optimum water status, while avoiding over-irrigation at the same time; (ii) sustained deficit irrigation (SDI), irrigated at $50 \%$ of the $\mathrm{ET}_{\mathrm{c}}$ until harvest; (iii) early deficit (ED), where pre-veraison irrigation was withheld until stem water potential $\left(\Psi_{\text {stem }}\right)$ values reached $-1.0 \mathrm{MPa}$, and thereafter, $100 \% \mathrm{ET}_{\mathrm{c}}$; and (iv) late deficit (LD), irrigated as for the Control until the end of veraison [when all berries are soft, about 108 days after budburst] and thereafter at $25 \% \mathrm{ET}_{\mathrm{c}}$ until harvest. This severity of water restriction was applied in an 
attempt to create in the LD treatment a seasonal pattern of water stress similar to that provoked in the ED treatment.

Irrigation began when midday $\Psi_{\text {stem }}$ values reached $-0.65 \mathrm{MPa}$, which occurred at about 40 days after budburst. After harvest, the different irrigation treatments were suspended, and a recovery irrigation period of $100 \% \mathrm{ET}_{\mathrm{c}}$ was applied to all plants for 2-3 weeks. Nevertheless, only about $18 \mathrm{~mm}$ were applied after harvest, due to the rainfall registered during the autumn period, which is usually rainy at the experimental site. The reasoning behind the recovery irrigation was that once the agronomical response was already recorded at harvest, we did not want to provoke early dormancy and an unequal impact on the accumulation of nutritional reserves (Ferreyra et al. 2003). The experimental design was a randomised complete block layout with four replicates. Each experimental unit (EU) consisted of 24-48 vines plus the surrounding perimeter vines acting as borders (5-6 rows $x$ 10-12 vines/row). The different irrigation regimes were applied from 2012 to 2014 and in 2015, and any carry over effects on shoot fruitfulness were determined at harvest.

Irrigation water came from a collective pressurised network and was of adequate quality, with an electrical conductivity $\left(\mathrm{EC}_{25^{\circ} \mathrm{C}}\right.$ ) of $1.07 \mathrm{dS} / \mathrm{m}$ and a chloride concentration of $2.6 \mathrm{meq} / \mathrm{L}$. Irrigation was applied through $4 \mathrm{~L} / \mathrm{h}$ pressure-compensated emitters spaced $100 \mathrm{~cm}$ along a single drip line down the row. Irrigation scheduling was adjusted in case of rain, dismissing precipitation if the rain was less than $2 \mathrm{~mm}$ and considering it effective only if it fell within $0.5 \mathrm{~m}$ from each side of the row. Additionally, soil water content was monitored continuously in three vines throughout the seasons by means of capacitance probes (Frequency Domain Reflectometry, EnviroSCAN, Sentek Sensor Technologies, Stepney, SA, Australia) installed in the wetted zone of an emitter of the Control treatment EUs, equipped with sensors ranging from 20 to $150 \mathrm{~cm}$ in depth, placed every 10 to $40 \mathrm{~cm}$. These measurements were used for scheduling irrigation duration and frequency, by maintaining the first metre in depth at approximately field capacity, for avoiding excesses 
and subsequent leaching losses. Water was applied at night and the duration was the same for all treatments, varying in frequency from 3 to 5 days per week. Water meters measured the amount applied to each EU. All treatments were fertigated at a rate of 111-73-214-24 $\mathrm{kg} / \mathrm{ha}$ of $\mathrm{N}, \mathrm{P}_{2} \mathrm{O}_{5}, \mathrm{~K}_{2} \mathrm{O}$ and $\mathrm{MgO}$, respectively.

\section{Water relations}

The $\Psi_{\text {stem }}$ was determined with a pressure chamber on bag-covered leaves from four representative vines per EU on a weekly basis from May to October at midday (1130-1230 solar time). Leaves were taken from the west side of the row and were enclosed in hermetic plastic bags covered with aluminium foil at least $1 \mathrm{~h}$ prior to the measurement.

The additive effect of water deficit duration and intensity was accounted for by the water stress integral $\left(\mathrm{S}_{\Psi}\right)$ computed as the sum of plant water potential measured every day during a given period (Myers 1988). It was calculated from the $\Psi_{\text {stem }}$ values determined weekly, subtracting those with the least negative value registered during the season $(-0.24$ $\mathrm{MPa}$ ) and multiplying it by the number of days.

\section{Yield and vegetative growth}

Yield, number of clusters per vine and average cluster mass were determined at commercial harvest (about $22^{\circ}$ Brix) on each experimental vine. Additionally, the number of clusters per shoot was counted in 2015 , once the experiment was finished, and the entire plot was irrigated as the Control. Berry fresh mass was determined on random samples from 250 berries per EU, which were periodically collected on every vine (5-10 berries per vine) from mid-June until harvest. The number of berries per cluster was counted from samples of 10 clusters per experimental unit.

Leaf area (LA) per vine was determined 2-3 weeks after veraison at eight selected vines per EU, when the main shoot growth had ceased and the growth of the secondary shoots had slowed down, but before the basal leaves had started falling, when LA was at its 
maximum size. Leaf area was estimated from allometric relations between shoot length (X, $\mathrm{cm})$ and leaf area per shoot $(\mathrm{Y}, \mathrm{cm} 2)$ measured with LI-3100 Area Meter (LI-COR, Lincoln, NE, USA), separating main and lateral shoot $\left(y=16.719 x+486.64, r 2=0.95^{* * *}\right.$ and $y=19.129 x$, $\mathrm{r} 2=0.97^{* * *}$, respectively). The LA from basal leaves at veraison was estimated following the same protocol. These relations were obtained from the sampling of 20 shoots of different vigour. Leaf area index (LAI) was calculated as the one-sided green LA per unit ground surface area. Leaf area-to-yield ratio (LA/Y) was also calculated in these eight selected vines per EU. The crop load was also estimated as the vine yield to dormant pruning mass, so called Ravaz index (Ravaz and Sicard 1903, Bravdo et al. 1985). Water use efficiency (WUE) was estimated as the ratio between yield and the amount of total rainfall plus irrigation applied to each EU(Hsiao et al. 2007).

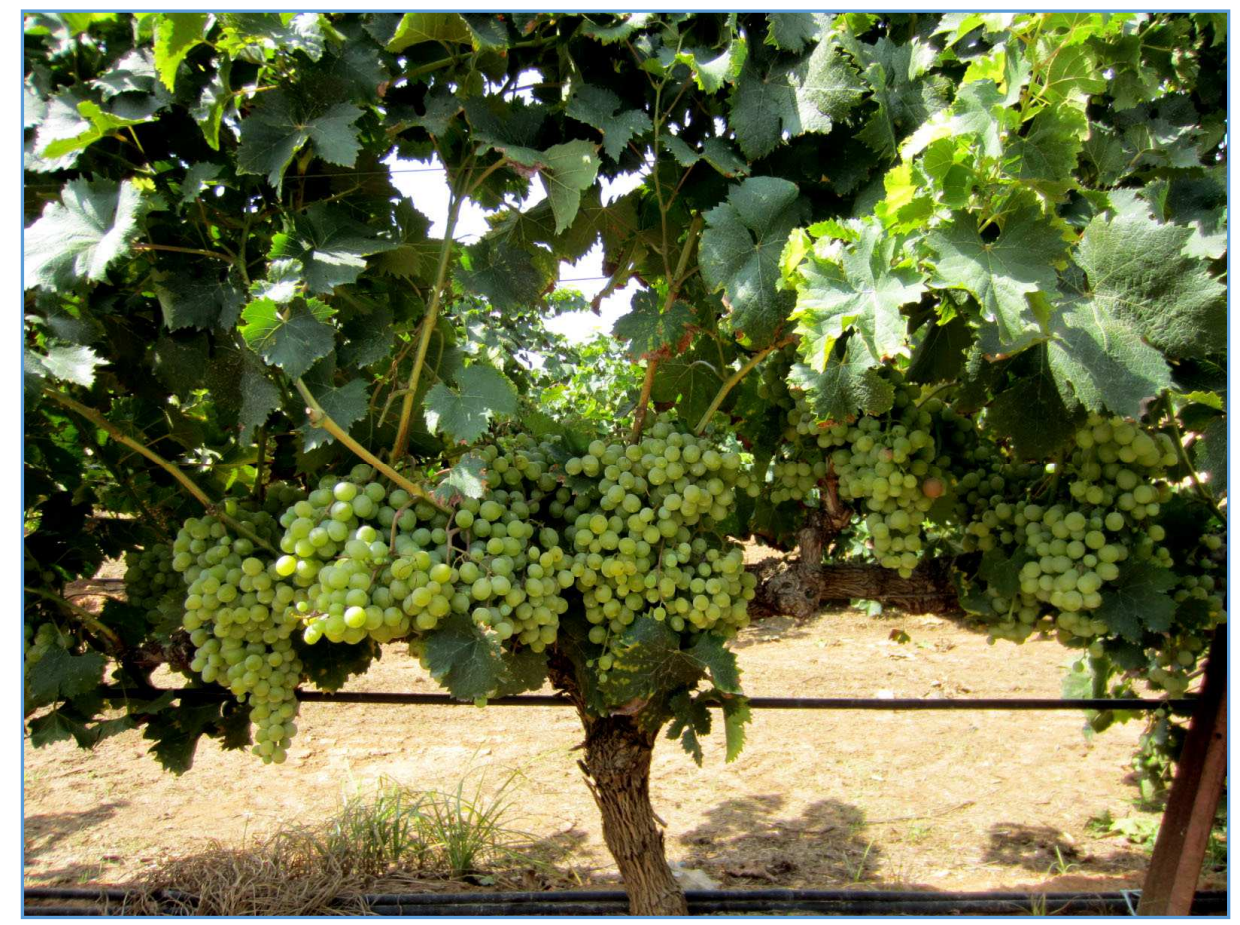

Figure 14. Appearance of the east side of a Muscat of Alexandria vine near harvest in 2013.

Grape composition

Must composition was determined in two subsamples weighing about $250 \mathrm{~g}$, which came from the same samples collected for determination of berry mass. Berries were 
crushed with a Thermomix blender and hand-pressed through a metal screen filter. Juice TSS ( $\left.{ }^{\circ} \mathrm{Brix}\right)$ was determined by refractometry and juice $\mathrm{pH}$ and TA by titration with $\mathrm{NaOH}$, expressed in tartaric acid equivalents, were determined with an automatic titrator. Malic acid and tartaric acid were determined by colorimetric methods using an automated sequential analyser (Easychem Plus, Systea, Anagni, Italy). All analytical determinations in musts were in duplicate. In order to assess the effects on grape maturity of the treatments, the Total Soluble Solids-to-titratable acidity ratio (TSS-to-TA) was calculated at harvest as a maturity index (Kliewer and Weaver 1971).

\section{Statistical analysis}

The effect of irrigation treatments, season and their interaction was subjected to ANOVA using the mixed procedure from the SAS statistical package (version 9.0; SAS Institute, Cary, NC, USA). Differences among treatments were assessed by Dunnett's $t$-test against the Control, and by designed contrasts between pairs of irrigation treatments. Data shown are seasonal averages and the average values for the whole experiment. In addition, the significance of the season effect and the interaction effect between treatment (T) and season $(\mathrm{S})$ is shown $\left(\mathrm{T}^{*} \mathrm{~S}\right)$. For the shoot fruitfulness parameter, the data are also presented as a seasonal bar graph due to the inclusion of data from the 2015 season.

\section{Results}

Climate and water relations

The results presented correspond to 2 dry years, 2012 and 2014, and a wetter one, 2013. Values from budburst until harvest of GDD, $\mathrm{ET}_{\mathrm{o}}, \mathrm{ET}_{\mathrm{c}}$, rainfall and irrigation applied in each year are shown in Table 2. Harvest took place on the day of the year 265 in 2012, 283 in 2013 and 261 in 2014. Averaged from the 3 years studied, the seasonal irrigation volume applied was $259 \mathrm{~mm}$ for the Control, $136 \mathrm{~mm}$ for the SDI, $154 \mathrm{~mm}$ for the ED and $185 \mathrm{~mm}$ 
for the LD treatment. Thus, respectively, in the SDI, ED and LD treatments, 48,40 and 29\% less water was applied when compared to that of the Control. These water savings caused vine water stress, which is presented seasonally by means of $S_{\Psi}$ in Table 3 . As expected, the ED treatment reached the highest $S_{\Psi}$ values from anthesis till veraison, and the LD from veraison till harvest, although in some seasons these values did not differ significantly from that of the SDI treatment. On the seasonal average, only the $S_{\Psi}$ experienced by the Control turned out significantly different from the other treatments, whose values were similar. However, the seasonal $S_{\Psi}$ reached by the ED and LD during the periods before and after veraison was significantly different, except during the first period of the wettest year (2013).

Table 2. Values of climate variables and irrigation amounts from budburst until harvest for each treatment during the 3 years of the experiment in Vilamarxant (Valencia), Spain.

\begin{tabular}{|c|c|c|c|c|c|c|c|c|}
\hline \multirow{2}{*}{ Year } & \multirow{2}{*}{$\begin{array}{c}\text { GDD } \\
\text { (o day) } \\
\end{array}$} & \multirow{2}{*}{$\begin{array}{c}\text { ETo, } \\
\text { (mm) }\end{array}$} & \multirow{2}{*}{$\begin{array}{l}\text { ETc, } \\
(\mathrm{mm})\end{array}$} & \multirow{2}{*}{$\begin{array}{c}\text { Rainfall } \\
(\mathrm{mm})\end{array}$} & \multicolumn{4}{|c|}{ Irrigation (mm) } \\
\hline & & & & & Control & ED & LD & SDI \\
\hline 2012 & 2039 & 831 & 288 & 31 & 277 & 176 & 217 & 155 \\
\hline 2013 & 2075 & 847 & 293 & 183 & 231 & 134 & 159 & 119 \\
\hline 2014 & 2055 & 847 & 300 & 98 & 268 & 152 & 179 & 133 \\
\hline Average & 2056 & 842 & 294 & 104 & 259 & 154 & 185 & 136 \\
\hline
\end{tabular}

ED, early deficit irrigation; ETc, estimated crop evapotranspiration; ETo, reference evapotranspiration; GDD, growing degree days; LD, late deficit irrigation; SDI, sustained deficit irrigation. 


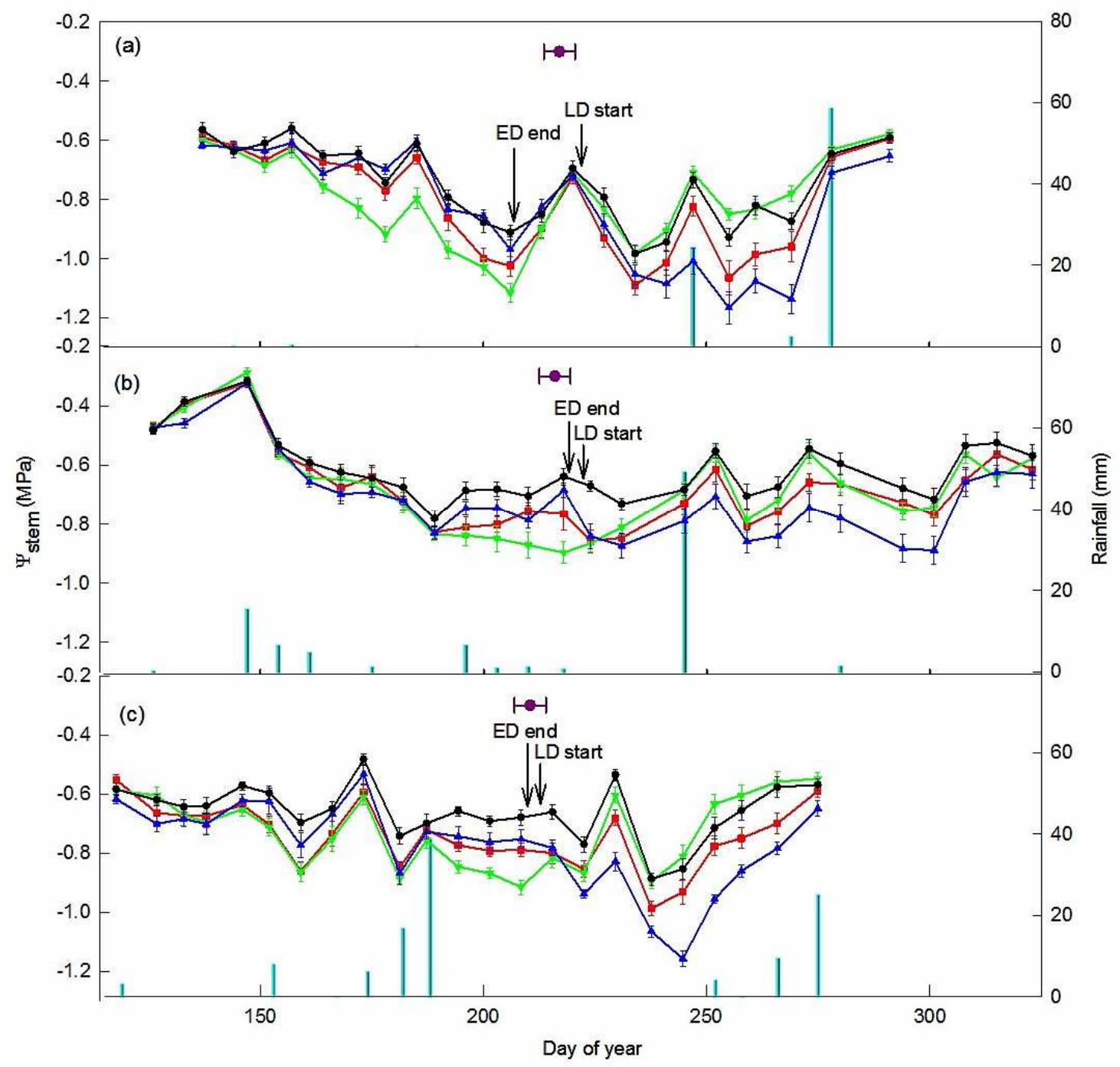

Figure 15. Effect of sustained deficit $(\square)$, early deficit (ED) ( $\nabla)$ and late deficit (LD) ( $\mathbf{\Delta})$ irrigation treatments on the seasonal evolution of midday stem water potential $\left(\Psi_{\text {stem }}\right)$ of Muscat of Alexandria grapevines in (a) 2012, (b) 2013 and (c) 2014 compared to that of the Control $(\bullet)$. Data are averages and standard errors of 16 leaves per treatment and date. Veraison (mean \pm SD) $(\bullet)$, the start/end of irrigation $(\downarrow)$ and rainfall ( $\mid$ ) are indicated.

The seasonal evolution of $\Psi_{\text {stem }}$ is presented in Figure 15, showing that vine water status was clearly and quickly affected by the different drip-irrigation treatments, once the soil moisture accumulated by rainfall had been depleted. Thus, the differences among treatments were smaller in 2013 than in the other 2 drier years. The more heavily irrigated Control vines showed a less negative $\Psi_{\text {stem }}$ than those of the DI treatments during most of the season, with average values around -0.6 to -0.7 MPa. The LD treatment decreased $\Psi_{\text {stem }}$ 
faster than ED once the irrigation restriction started, even when $25 \% \mathrm{ET}_{\mathrm{c}}$ was applied. It should also be noted that the ED and LD treatments responded quickly to the change in water application once the restriction ended or started. Usually, the SDI vines showed intermediate values between those from the Control and the more intense stress treatments (ED or LD). For instance, during the stage from anthesis to veraison, the $S_{\Psi}$ was significantly higher by $16 \%$ for SDI and $27 \%$ for ED as compared to that of the Control (Table 3). And during the ripening period, the $S_{\Psi}$ was 20 and 35\% higher for SDI and LD treatments, respectively.

Table 3. Values of the water stress integral $\left(S_{\Psi}\right)$ during the period from anthesis to veraison and from veraison to harvest during the 3 years of the experiment, and the seasonal average for Muscat of Alexandria wine grapes subjected to different irrigation strategies.

\begin{tabular}{|c|c|c|c|c|c|c|c|c|c|}
\hline \multirow[b]{2}{*}{ Period } & \multirow[b]{2}{*}{ Year } & \multicolumn{3}{|c|}{ Treatment } & \multicolumn{3}{|c|}{$\begin{array}{c}\text { Significance } \\
\text { of effect }\end{array}$} & \multicolumn{2}{|c|}{ Contrasts } \\
\hline & & Control & ED & LD & SDI & $\mathbf{T}$ & $\begin{array}{l}\text { ED- } \\
\text { LD }\end{array}$ & $\begin{array}{l}\text { ED- } \\
\text { SDI }\end{array}$ & $\begin{array}{l}\text { LD- } \\
\text { SDI }\end{array}$ \\
\hline \multirow{4}{*}{$\begin{array}{l}\text { Anthesis- } \\
\text { veraison }\end{array}$} & 2012 & $31.6 a$ & $40.7 \mathrm{c}$ & $32.4 \mathrm{ab}$ & $35.4 \mathrm{~b}$ & $<0.001$ & $<0.001$ & 0.003 & 0.071 \\
\hline & 2013 & $27.8 a$ & $32.3 \mathrm{~b}$ & $30.4 \mathrm{ab}$ & $30.3 a b$ & 0.045 & 0.345 & 0.288 & 0.906 \\
\hline & 2014 & $31.8 \mathrm{a}$ & $42.7 \mathrm{c}$ & $35.7 \mathrm{ab}$ & $39.4 \mathrm{bc}$ & $<0.001$ & 0.001 & 0.105 & 0.079 \\
\hline & Average & $30.4 a$ & $38.6 \mathrm{c}$ & $32.6 a b$ & $35.1 \mathrm{~b}$ & $<0.001$ & $<0.001$ & 0.006 & 0.052 \\
\hline \multirow{4}{*}{$\begin{array}{c}\text { Veraison- } \\
\text { harvest }\end{array}$} & 2012 & $31.4 a$ & $30.9 a$ & $39.8 b$ & $37.1 \mathrm{~b}$ & $<0.001$ & $<0.001$ & 0.002 & 0.176 \\
\hline & 2013 & $29.2 \mathrm{a}$ & $30.3 \mathrm{ab}$ & $39.6 c$ & $35.9 \mathrm{bc}$ & 0.014 & 0.005 & 0.085 & 0.212 \\
\hline & 2014 & $26.1 \mathrm{a}$ & $27.2 \mathrm{a}$ & $37.6 \mathrm{c}$ & $31.6 \mathrm{~b}$ & $<0.001$ & $<0.001$ & 0.009 & 0.001 \\
\hline & Average & $28.9 a$ & $29.3 a$ & $39.1 c$ & $34.8 \mathrm{~b}$ & $<0.001$ & $<0.001$ & $<0.001$ & 0.002 \\
\hline $\begin{array}{c}\text { Anthesis- } \\
\text { harvest }\end{array}$ & Average & $59.3 a$ & $67.9 \mathrm{~b}$ & $71.7 \mathrm{~b}$ & $69.9 \mathrm{~b}$ & $<0.001$ & 0.093 & 0.445 & 0.350 \\
\hline
\end{tabular}

Data are averages of 4 experimental units per treatment $(n=16)$. T, treatment; ED, early deficit; LD; late deficit; SDI, sustained deficit irrigation treatments. 
Table 4. Average values of vegetative growth over the 3 years of the experiment for Muscat of Alexandria wine grapes subjected to different irrigation strategies.

\begin{tabular}{|c|c|c|c|c|c|c|c|c|c|c|c|}
\hline \multirow{2}{*}{ Parameter } & \multirow{2}{*}{ Season } & \multicolumn{4}{|c|}{ Treatment } & \multicolumn{3}{|c|}{ Significance of effects } & \multicolumn{3}{|c|}{ Contrasts } \\
\hline & & Control & ED & LD & SDI & $\mathbf{T}$ & $S$ & $\mathbf{T} * \mathbf{S}$ & ED-LD & ED-SDI & LD-SDI \\
\hline \multirow{4}{*}{$\begin{array}{c}\text { Shoots/ } \\
\text { vine }\end{array}$} & 2012 & 19.9 & 19.4 & 19.3 & 20.0 & 0.61 & - & - & 0.90 & 0.35 & 0.30 \\
\hline & 2013 & 19.7 & 18.3 & 19.0 & 19.1 & 0.26 & - & - & 0.32 & 0.23 & 0.83 \\
\hline & 2014 & 20.1 & 18.4 & 18.8 & 19.0 & 0.07 & - & - & 0.14 & 0.09 & 0.76 \\
\hline & Average & 19.9 & 18.8 & 19.0 & 19.3 & 0.12 & 0.001 & 0.18 & 0.40 & 0.17 & 0.56 \\
\hline \multirow{4}{*}{$\begin{array}{c}\text { LAI } \\
\left(\mathrm{m}^{2} / \mathrm{m}^{2}\right)\end{array}$} & 2012 & $2.1 \mathrm{a}$ & $1.4 \mathrm{c}$ & $1.6 \mathrm{~b}$ & $1.4 \mathrm{c}$ & $<0.001$ & - & - & $<0.001$ & 0.22 & $<0.001$ \\
\hline & 2013 & $1.7 \mathrm{a}$ & $1.4 \mathrm{~b}$ & $1.3 \mathrm{~b}$ & $1.4 \mathrm{~b}$ & 0.009 & - & - & 0.64 & 0.42 & 0.22 \\
\hline & 2014 & $1.6 a$ & $0.9 \mathrm{~b}$ & $1.0 \mathrm{~b}$ & $1.1 \mathrm{~b}$ & 0.002 & - & - & 0.37 & 0.19 & 0.66 \\
\hline & Average & $1.8 \mathrm{a}$ & $1.2 \mathrm{c}$ & $1.3 \mathrm{~b}$ & $1.3 \mathrm{bc}$ & $<0.001$ & 0.001 & 0.02 & 0.033 & 0.07 & 0.73 \\
\hline \multirow{4}{*}{$\begin{array}{c}\text { Pruning } \\
\text { mass } \\
\text { (Kg/vine) }\end{array}$} & 2012 & $1.08 \mathrm{a}$ & $0.63 b$ & $0.74 b$ & $0.77 \mathrm{~b}$ & $<0.001$ & - & - & 0.18 & 0.10 & 0.76 \\
\hline & 2013 & $0.99 a$ & $0.73 \mathrm{~b}$ & $0.69 b$ & $0.76 \mathrm{~b}$ & $<0.001$ & - & - & 0.55 & 0.57 & 0.24 \\
\hline & 2014 & $0.76 \mathrm{a}$ & $0.459 b$ & $0.53 b$ & $0.55 b$ & $<0.001$ & - & - & 0.21 & 0.13 & 0.79 \\
\hline & Average & $0.94 a$ & $0.60 \mathrm{~b}$ & $0.65 b$ & $0.69 \mathrm{~b}$ & $<0.001$ & 0.023 & 0.99 & 0.22 & 0.07 & 0.52 \\
\hline \multirow{4}{*}{$\begin{array}{c}\mathrm{LA} / \mathrm{Y} \\
\left(\mathrm{m}^{2} / \mathrm{kg}\right)\end{array}$} & 2012 & $0.67 a$ & $0.48 b$ & $0.53 b$ & $0.47 \mathrm{~b}$ & 0.04 & - & - & 0.42 & 0.92 & 0.36 \\
\hline & 2013 & 0.43 & 0.45 & 0.42 & 0.44 & 0.58 & - & - & 0.19 & 0.78 & 0.30 \\
\hline & 2014 & 1.44 & 1.26 & 1.41 & 1.08 & 0.38 & - & - & 0.50 & 0.46 & 0.16 \\
\hline & Average & 0.74 & 0.67 & 0.68 & 0.58 & 0.41 & $<0.001$ & 0.48 & 0.93 & 0.37 & 0.33 \\
\hline
\end{tabular}




\begin{tabular}{cccccccccccc}
\hline $\begin{array}{c}\text { Ravaz index } \\
\text { (Yield/ }\end{array}$ & 2012 & $13.7 \mathrm{~b}$ & $18.5 \mathrm{a}$ & $17.9 \mathrm{ab}$ & $18.7 \mathrm{a}$ & 0.03 & - & - & 0.76 & 0.89 & 0.65 \\
$\begin{array}{c}\text { pruning } \\
\text { mass) }\end{array}$ & 2013 & 21.8 & 22.2 & 23.9 & 22.7 & 0.42 & - & - & 0.20 & 0.67 & 0.39 \\
& Average & $14.8 \mathrm{~b}$ & $16.5 \mathrm{ab}$ & $17.0 \mathrm{a}$ & $17.2 \mathrm{a}$ & 0.012 & $<0.001$ & 0.16 & 0.54 & 0.35 & 0.75 \\
\hline & 2012 & $7.4 \mathrm{~b}$ & $7.3 \mathrm{~b}$ & $7.8 \mathrm{~b}$ & $10.8 \mathrm{a}$ & 0.01 & - & - & 0.61 & 0.01 & 0.01 \\
WUE & 2013 & 9.9 & 10.7 & 9.9 & 11.2 & 0.67 & - & - & 0.52 & 0.72 & 0.32 \\
$\mathbf{( k g / \mathbf { m } ^ { 3 } )}$ & 2014 & $3.8 \mathrm{ab}$ & $3.5 \mathrm{~b}$ & $3.8 \mathrm{ab}$ & $4.3 \mathrm{a}$ & 0.06 & - & - & 0.30 & 0.01 & 0.06 \\
& Average & $7.0 \mathrm{~b}$ & $7.2 \mathrm{~b}$ & $7.2 \mathrm{~b}$ & $8.8 \mathrm{a}$ & 0.011 & $<0.001$ & 0.27 & 0.97 & 0.01 & 0.01 \\
\hline
\end{tabular}

Data are averages of 4 experimental units per treatment. Within each row, mean values followed by a different letter are significantly different at $\mathrm{P}<0.05$. For data analysis across years, the statistical significance effect of year, treatment by year interaction and contrasts between deficit irrigated treatments are also indicated. T, treatment; S, Season; ED, early deficit irrigation treatment; LD, late deficit irrigation treatment; SDI, sustained deficit irrigation treatment; LAI, leaf area index; LA/Y, leaf area to yield; Y/P, yield to pruning mass; WUE, water use efficiency. 
Table 5. Average values of yield components over 3 years for Muscat of Alexandria wine grapes subjected to different irrigation strategies.

\begin{tabular}{|c|c|c|c|c|c|c|c|c|c|c|c|}
\hline \multirow[b]{2}{*}{ Parameter } & \multirow[b]{2}{*}{ Season } & \multicolumn{4}{|c|}{ Treatment } & \multicolumn{3}{|c|}{ Significance of effects } & \multicolumn{3}{|c|}{ Contrasts } \\
\hline & & Control & ED & LD & SDI & $\mathbf{T}$ & $\mathbf{S}$ & $\mathbf{T} *$ year & ED-LD & $\begin{array}{l}\text { ED- } \\
\text { SDI } \\
\end{array}$ & LD-SDI \\
\hline \multirow{4}{*}{$\begin{array}{l}\text { Yield, } \\
\text { (t/ha) }\end{array}$} & 2012 & $26.9 \mathrm{a}$ & $19.0 \mathrm{~b}$ & $24.6 \mathrm{ab}$ & $26.1 \mathrm{a}$ & 0.05 & - & - & 0.08 & 0.02 & 0.40 \\
\hline & 2013 & 39.4 & 31.5 & 32.7 & 31.9 & 0.24 & - & - & 0.87 & 0.98 & 0.89 \\
\hline & 2014 & $13.9 \mathrm{a}$ & $8.5 \mathrm{c}$ & $10.5 b$ & $10.1 b$ & $<0.001$ & - & - & 0.01 & 0.02 & 0.53 \\
\hline & Average & $26.3 \mathrm{a}$ & $19.0 \mathrm{~b}$ & $22.2 \mathrm{~b}$ & $22.6 \mathrm{ab}$ & 0.004 & $<0.001$ & 0.62 & 0.15 & 0.09 & 0.80 \\
\hline \multirow{4}{*}{$\begin{array}{c}\text { Clusters/ } \\
\text { vine }\end{array}$} & 2012 & 30.9 & 28.3 & 29.1 & 31.7 & 0.28 & - & - & 0.68 & 0.10 & 0.19 \\
\hline & 2013 & $35.1 \mathrm{a}$ & $29.7 b$ & $33.4 \mathrm{ab}$ & $31.8 \mathrm{ab}$ & 0.06 & - & - & 0.06 & 0.27 & 0.35 \\
\hline & 2014 & $23.0 \mathrm{a}$ & $19.8 b$ & $18.8 \mathrm{~b}$ & $19.8 b$ & 0.02 & - & - & 0.37 & 1.00 & 0.37 \\
\hline & Average & $29.7 \mathrm{a}$ & $26.0 \mathrm{~b}$ & $27.1 \mathrm{~b}$ & $27.8 \mathrm{ab}$ & 0.005 & $<0.001$ & 0.26 & 0.23 & 0.07 & 0.51 \\
\hline \multirow{4}{*}{$\begin{array}{c}\text { Shoot } \\
\text { fruitfulness } \\
\text { (number of } \\
\text { clusters/ } \\
\text { Shoot) }\end{array}$} & 2012 & $1.59 \mathrm{a}$ & $1.48 \mathrm{~b}$ & $1.55 \mathrm{ab}$ & $1.59 \mathrm{a}$ & 0.05 & - & - & 0.15 & 0.01 & 0.29 \\
\hline & 2013 & $1.90 \mathrm{a}$ & $1.70 \mathrm{~b}$ & $1.90 \mathrm{a}$ & $1.80 \mathrm{~b}$ & $<0.001$ & - & - & $<0.001$ & 0.27 & $<0.001$ \\
\hline & 2014 & $1.15 \mathrm{a}$ & $1.11 \mathrm{a}$ & $0.98 \mathrm{~b}$ & $1.04 \mathrm{~b}$ & 0.002 & - & - & 0.002 & 0.09 & 0.17 \\
\hline & Average & $1.51 \mathrm{a}$ & $1.41 \mathrm{~b}$ & $1.43 \mathrm{~b}$ & $1.43 \mathrm{~b}$ & 0.008 & $<0.001$ & $<0.001$ & 0.30 & 0.36 & 0.91 \\
\hline \multirow{4}{*}{$\begin{array}{l}\text { Cluster } \\
\text { mass (g) }\end{array}$} & 2012 & $425 a$ & $326 b$ & $405 a$ & $406 a$ & 0.009 & - & - & 0.01 & 0.01 & 0.98 \\
\hline & 2013 & 553 & 522 & 479 & 484 & 0.25 & - & - & 0.25 & 0.39 & 0.85 \\
\hline & 2014 & $297 a$ & $205 b$ & $266 a$ & $248 a b$ & 0.009 & - & - & 0.02 & 0.07 & 0.38 \\
\hline & Average & $425 a$ & $351 b$ & $383 \mathrm{ab}$ & $379 \mathrm{ab}$ & 0.006 & $<0.001$ & 0.18 & 0.11 & 0.16 & 0.82 \\
\hline
\end{tabular}




\begin{tabular}{cccccccccccc}
\hline \multirow{2}{*}{$\begin{array}{c}\text { Berries/ } \\
\text { cluster }\end{array}$} & 2012 & 94 & 87 & 84 & 89 & 0.60 & - & - & 0.64 & 0.82 & 0.50 \\
& 2013 & 124 & 119 & 118 & 123 & 0.79 & - & - & 0.97 & 0.51 & 0.48 \\
& 2014 & 67 & 61 & 64 & 65 & 0.85 & - & - & 0.69 & 0.54 & 0.83 \\
& Average & 95 & 89 & 89 & 93 & 0.43 & $<0.001$ & 0.08 & 0.94 & 0.98 & 0.94 \\
\hline \multirow{2}{*}{$\begin{array}{c}\text { Berry mass } \\
\text { (g) }\end{array}$} & 2012 & $5.6 \mathrm{a}$ & $4.5 \mathrm{~b}$ & $5.4 \mathrm{a}$ & $5.3 \mathrm{ab}$ & 0.04 & - & - & 0.03 & 0.06 & 0.64 \\
& 2013 & 4.7 & 4.3 & 4.4 & 4.4 & 0.16 & - & - & 0.39 & 0.30 & 0.85 \\
& 2014 & 5.5 & 4.6 & 5.2 & 5.0 & 0.17 & - & - & 0.12 & 0.29 & 0.55 \\
\hline
\end{tabular}

Data are averages of 4 experimental units per treatment. Within each row, mean values followed by a different letter are significantly different at $P<0.05$. For data analysis across years, the statistical significance effect of year, treatment by year interaction and contrasts between deficit irrigated treatments are also indicated. T, treatment; S, Season; ED, early deficit irrigation treatment; LD, late deficit irrigation treatment; SDI, sustained deficit irrigation treatment. 
Vegetative growth and yield

Vine phenological stages, budburst, flowering, veraison and harvest, averaged for the 3 years studied occurred at $68,415,1228$ and $2069{ }^{\circ} \mathrm{C}$ day, respectively. The date when these occurred was quite steady during the 3 years, with only 10 days of difference between the earliest, 2014, and the latest, 2013. In spite of this, seasonal effects on all the vegetative growth and yield parameters studied were significant (Table 4). The number of shoots per vine showed no difference among treatments, since the pruning criteria were the same. Nonetheless, pruning mass per vine was significantly $(P<0.05)$ higher in the Control than in the other treatments, as a significant inverse relationship between pruning mass and $S_{\Psi}$ was found. Additionally, the Control vines had the highest total LA per vine, which was found to be significantly lower in the ED than in LD vines. Such a significant difference, however, was observed only in 2012 , as the effect of the treatment on this parameter varied with the season (Table 4). The SDI treatment, on average, showed values that were intermediate between that of the ED and LD treatments. This effect was mainly due to the difference in lateral shoot growth, as the main LA was similar in all treatments (data not shown); therefore, Control vines had a more compact canopy.

Pooling data across seasons all DI treatments had reduced shoot fruitfulness (clusters per shoot) as compared to the Control, and therefore the DI vines also had fewer clusters per vine, although this last difference was significant only for the average of the ED and LD treatments (Table 5). Variation in shoot fruitfulness among treatments, however, was not consistent among seasons (Figure 16). Moreover, berry fresh mass was decreased significantly by water deficit in spring (e.g. ED and SDI), showing a seasonal significant inverse relation with the $S_{\Psi}$ during pre-veraison $(P<0.001)$. In addition, ED caused a significant reduction in cluster mass, whereas there was no difference between the other treatments (Table 5). This was due to the decrease in berry mass experienced by ED. Nevertheless, berry number per cluster was unaffected by the irrigation treatment. 
Due to the reduction in the number of clusters per vine and in cluster and berry mass, yield was significantly reduced on average for the ED and LD treatments by 25.2 and $15.3 \%$, respectively, compared to that of the Control. Average yield for the SDI treatment was intermediate and neither differed from that of the Control nor from the other two DI treatments. It is important to note that, yield reduction appears to be cumulative in every DI treatment over the 3 years of the experiment, with a mean decrease of 13,18 and $30 \%$ (Table 5). Nonetheless, longer term research is needed to confirm these findings because it should be noted that there was a significant year-to-year yield variability in all treatments.

As a consequence of the high fruit yield $(9.8-13.1 \mathrm{~kg} / \mathrm{vine}$ or $19.8-26.5 \mathrm{t} / \mathrm{ha}$ on average for the three seasons) and low vegetative growth and pruning mass, we obtained low values in the LA-to-yield ratio $\left(0.6-0.7 \mathrm{~m}^{2} / \mathrm{kg}\right)$ and high values in the Ravaz index (1517). Remarkably, WUE was highest for the SDI treatment, with a slight and non-significant difference found between the ED, LD and Control treatments (Table 4).

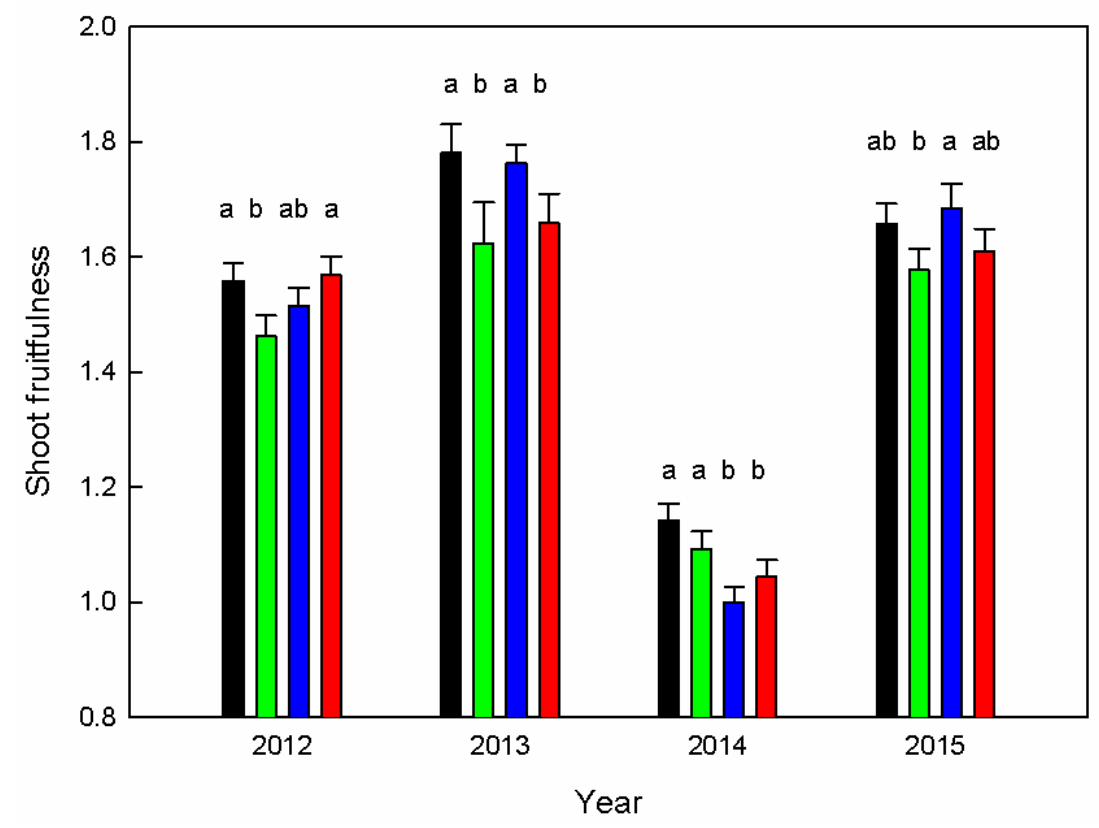

Figure 16. Effect of sustained deficit $(\square)$, early deficit $(\square)$ and late deficit $(\square)$ irrigation treatments on the shoot fruitfulness (clusters per shoot) of Muscat of Alexandria grapevines for the seasons 2012, 2013 and 2014 compared to that of the Control ( $\mathbf{m}$ ), and additionally, the carry-over effect in 2015. Data are the average and standard error of four experimental units per treatment measured at harvest. Different letters mean a significant difference among treatments for each season at $P<0.05$. 


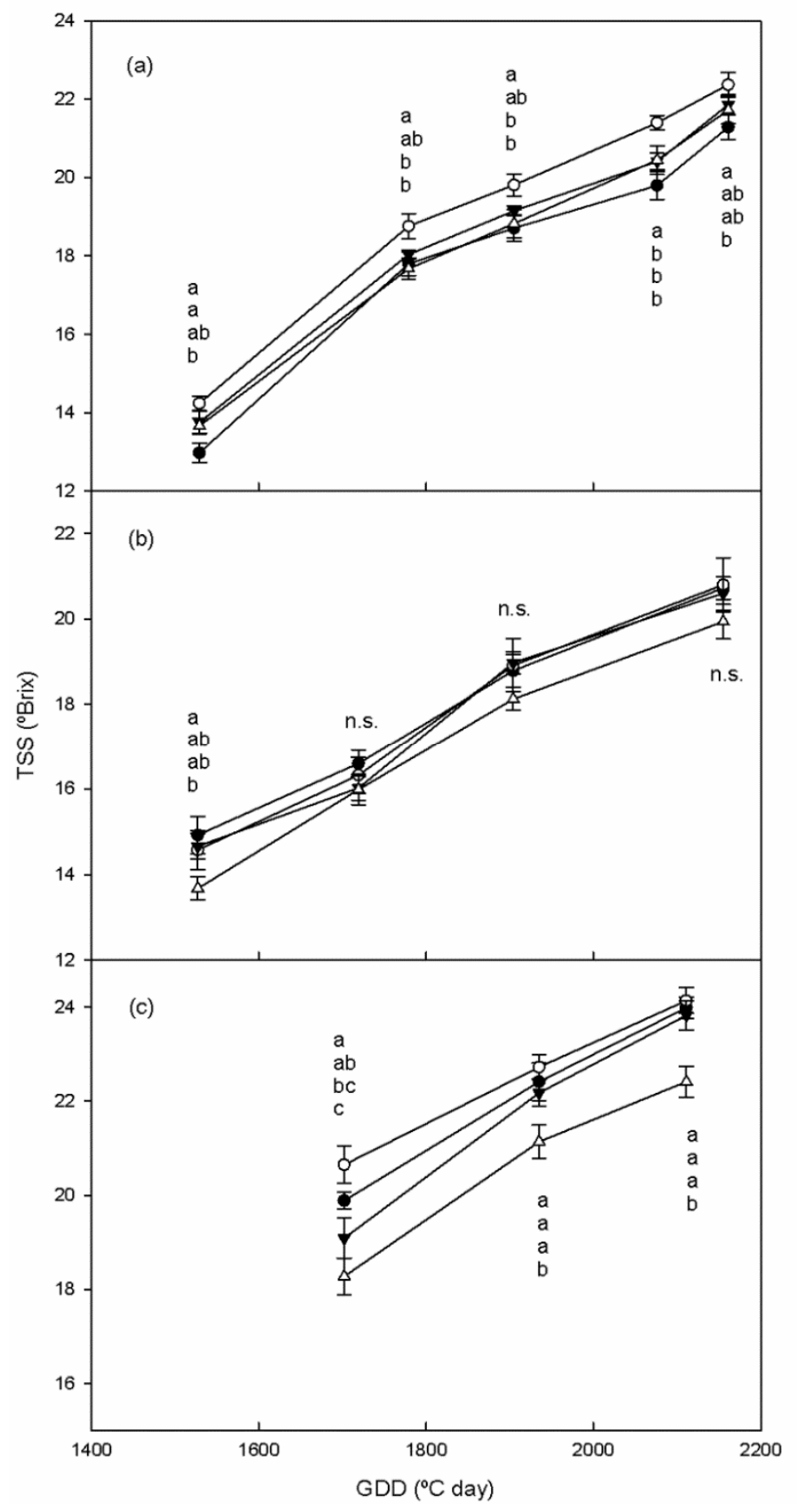

Figure 17. Effect of sustained deficit $(\bullet)$, early deficit $(0)$ and late deficit $(\boldsymbol{\nabla})$ irrigation treatments on the seasonal evolution of TSS in Muscat of Alexandria grapes for seasons (a) 2012, (b) 2013 and (c) 2014 compared to that of the Control $(\Delta)$. Data are the average of four replications per treatment and date. Different letters are placed in the same order as the symbols and denote a significant difference among treatments for each analysis at $P<0.05$. GDD, growing degree days; n.s., not significant. 
Table 6. Average values for must composition attributes at harvest for Muscat of Alexandria grapes subjected to different irrigation treatments during the 3 years of the experiment.

\begin{tabular}{|c|c|c|c|c|c|c|c|c|c|c|c|}
\hline \multirow{2}{*}{ Parameter } & \multirow{2}{*}{ Season } & \multicolumn{4}{|c|}{ Treatment } & \multicolumn{3}{|c|}{ Significance of effects } & \multicolumn{3}{|c|}{ Contrasts } \\
\hline & & Control & ED & LD & SDI & $\mathbf{T}$ & $\mathbf{S}$ & $\mathbf{T} * \mathbf{S}$ & ED-LD & ED-SDI & LD-SDI \\
\hline \multirow{4}{*}{ TSS (ํㅜrix) } & 2012 & 21.7ab & $22.4 \mathrm{a}$ & $21.9 \mathrm{ab}$ & $21.3 b$ & 0.13 & - & - & 0.23 & 0.03 & 0.19 \\
\hline & 2013 & 20.0 & 20.8 & 20.6 & 20.8 & 0.14 & - & - & 0.55 & 0.84 & 0.69 \\
\hline & 2014 & $22.4 \mathrm{~b}$ & $24.1 \mathrm{a}$ & $23.8 \mathrm{a}$ & $24.0 \mathrm{a}$ & $<0.001$ & - & - & 0.32 & 0.63 & 0.60 \\
\hline & Average & $21.4 \mathrm{c}$ & $22.4 \mathrm{a}$ & $22.1 \mathrm{ab}$ & $22.0 \mathrm{~b}$ & $<0.001$ & $<0.001$ & 0.02 & 0.09 & 0.04 & 0.64 \\
\hline \multirow{4}{*}{ pH } & 2012 & $3.86 a b$ & $3.82 \mathrm{~b}$ & $3.87 \mathrm{a}$ & $3.79 b$ & 0.05 & - & - & 0.05 & 0.31 & 0.02 \\
\hline & 2013 & 3.55 & 3.58 & 3.60 & 3.60 & 0.56 & - & - & 0.43 & 0.21 & 0.60 \\
\hline & 2014 & 3.92ab & $3.90 \mathrm{~b}$ & $3.96 a$ & 3.94 & 0.12 & - & - & 0.03 & 0.14 & 0.36 \\
\hline & Average & $3.78 \mathrm{ab}$ & $3.76 \mathrm{~b}$ & $3.80 \mathrm{a}$ & $3.77 \mathrm{ab}$ & 0.12 & $<0.001$ & 0.07 & 0.02 & 0.51 & 0.09 \\
\hline \multirow{4}{*}{$\begin{array}{c}\text { Titratable } \\
\text { acidity } \\
\text { (g/L) }\end{array}$} & 2012 & 3.66 & 3.02 & 3.21 & 3.04 & 0.22 & - & - & 0.56 & 0.96 & 0.60 \\
\hline & 2013 & 4.90 & 4.73 & 4.80 & 4.85 & 0.32 & - & - & 0.43 & 0.21 & 0.60 \\
\hline & 2014 & $4.45 \mathrm{a}$ & $4.14 \mathrm{~b}$ & $4.37 \mathrm{ab}$ & $4.39 \mathrm{a}$ & 0.08 & - & - & 0.07 & 0.05 & 0.82 \\
\hline & Average & $4.44 \mathrm{a}$ & $4.21 \mathrm{~b}$ & $4.37 \mathrm{ab}$ & $4.38 \mathrm{a}$ & 0.046 & $<0.001$ & 0.59 & 0.19 & 0.30 & 0.79 \\
\hline \multirow{4}{*}{$\begin{array}{l}\text { Malic acid } \\
\qquad(\mathrm{g} / \mathrm{L})\end{array}$} & 2012 & 2.48 & 2.28 & 2.50 & 2.17 & 0.34 & - & - & 0.31 & 0.21 & 0.02 \\
\hline & 2013 & 2.90 & 2.59 & 2.80 & 2.66 & 0.28 & - & - & 0.21 & 0.65 & 0.40 \\
\hline & 2014 & 3.18ab & $2.89 \mathrm{~b}$ & $3.37 \mathrm{a}$ & $3.11 \mathrm{ab}$ & 0.10 & - & - & 0.02 & 0.22 & 0.15 \\
\hline & Average & $2.85 \mathrm{a}$ & $2.58 \mathrm{~b}$ & $2.89 \mathrm{a}$ & $2.65 \mathrm{ab}$ & 0.016 & $<0.001$ & 0.82 & 0.01 & 0.57 & 0.03 \\
\hline
\end{tabular}




\begin{tabular}{cccccccccccc}
\hline & 2012 & $5.84 \mathrm{ab}$ & $5.89 \mathrm{ab}$ & $5.95 \mathrm{a}$ & $5.63 \mathrm{~b}$ & 0.14 & - & - & 0.66 & 0.71 & 0.03 \\
$\begin{array}{c}\text { Tartaric } \\
\text { acid }\end{array}$ & 2013 & 4.66 & 4.88 & 4.93 & 4.65 & 0.10 & - & - & 0.71 & 0.10 & 0.06 \\
(g/L) & 2014 & $5,24 \mathrm{a}$ & $4.70 \mathrm{a}$ & $5.13 \mathrm{a}$ & $3.97 \mathrm{~b}$ & $<0.001$ & - & - & 0.06 & 0.01 & $<0.001$ \\
& Average & $5.24 \mathrm{a}$ & $5.16 \mathrm{a}$ & $5.34 \mathrm{a}$ & $4.75 \mathrm{~b}$ & $<0.001$ & $<0.001$ & 0.001 & 0.07 & $<0.001$ & $<0.001$ \\
\hline \multirow{2}{*}{$\begin{array}{c}\text { Maturity } \\
\text { index }\end{array}$} & 2012 & 6.22 & 7.49 & 6.82 & 7.02 & 0.16 & - & - & 0.22 & 0.37 & 0.71 \\
(-Brix/g/L) & 2013 & $4.05 \mathrm{~b}$ & $4.42 \mathrm{a}$ & $4.29 \mathrm{ab}$ & $4.26 \mathrm{ab}$ & 0.05 & - & - & 0.29 & 0.20 & 0.80 \\
& Average & $5.11 \mathrm{~b}$ & $5.92 \mathrm{a}$ & $5.53 \mathrm{ab}$ & $5.58 \mathrm{ab}$ & 0.003 & $<0.001$ & 0.69 & 0.05 & 0.09 & 0.78 \\
\hline & 2012 & 2.35 & 2.70 & 2.40 & 2.60 & 0.24 & - & - & 0.13 & 0.59 & 0.30 \\
Tartaric/ & 2013 & 1.60 & 1.90 & 1.80 & 1.75 & 0.12 & - & - & 0.39 & 0.21 & 0.66 \\
malic ratio & 2014 & $1.68 \mathrm{a}$ & $1.65 \mathrm{a}$ & $1.53 \mathrm{ab}$ & $1.30 \mathrm{~b}$ & 0.09 & - & - & 0.40 & 0.04 & 0.14 \\
& Average & $1.88 \mathrm{~b}$ & $2.08 \mathrm{a}$ & $1.91 \mathrm{ab}$ & $1.88 \mathrm{~b}$ & 0.08 & $<0.001$ & 0.12 & 0.57 & 0.03 & 0.78 \\
\hline
\end{tabular}

Data are averages of 4 experimental units per treatment. Within each row, mean values followed by a different letter are significantly different at $\mathrm{P}<0.05$. For data analysis across years, the statistical significance effect of year, treatment by year interaction and contrasts between deficit irrigated treatments are also indicated. ED, early deficit, LD, late deficit and SDI, sustained deficit irrigation. TSS, Total Soluble Solids, TA, Total Acidity. 


\section{Berry composition}

Irrigation strategies produced little difference in berry composition at harvest (Table 6), the greatest being between Control and ED. On the three-season average, Control berries had a significantly lower TSS than that of all the DI treatments. The seasonal accumulation of berry TSS is presented in Figure 17. Furthermore, Control treatment tended to have higher TA that the DI treatments, since there was a slight trend of a higher TA and higher malic acid concentration as the amount of irrigation increased, but this was not apparent for tartaric acid. Nevertheless, the difference among treatments in TSS and tartaric acid concentration at harvest were not fully consistent between years, due to the effect of the year and their interaction with the treatments (Table 6). Remarkably, the difference in the $\mathrm{pH}$ value and the tartaric-to-malic acid ratio was significant only for ED as compared to that of the Control. Additionally, ED tended to ripen faster than Control treatment, with no difference in maturity index with LD or SDI.

\section{Discussion}

The water saving achieved by the SDI treatment was greater than that from the ED and LD treatments (Table 2), although the $S_{\Psi}$ experienced from anthesis until harvest was similar among DI treatments (Table 3). Water deficit, however, triggered different physiological responses depending on its timing and severity, implying that it was not only important to quantify the degree of water stress by measuring $\Psi_{\text {stem, but }}$ it was also necessary to know the phenological period when $S_{\Psi}$ was occurring (Table 3). In the Control treatment, $S_{\Psi}$ was quite similar during the three experimental seasons, while in the ED and SDI treatments there were more important variations in the $S_{\Psi}$ experienced among seasons, particularly during the period from anthesis to veraison. This is most likely because in the DI treatments, the seasonal variation in water status was also affected by the soil water available at the beginning of the stress period and the weather conditions during the period 
of application of deficit irrigation as well. Therefore, the exact timing of water stress and its intensity were slightly different between years, and the relationships found between $S_{\Psi}$ and some vine performance or berry composition parameters were not highly correlated. Moreover, other environmental factors besides water availability could have had a significant effect on vine performance and grape composition, such as light intensity or temperature during the phenological cycle. Similar relationships were observed by Baeza et al. (2007).

Reduced vegetative growth is one of the first plant responses to drought, which allows vines to restrict water loss (Hsiao 1973), as can be observed by the significant reduction in LA in all DI treatments as compared to that of the Control (Table 4). Water deficit prior to veraison, as expected (Wample and Smithyman 2002), was the most effective in reducing LA (ED and SDI), whilst water deficit during post-veraison did not affect so much the vegetative growth (in terms of increasing LA). In semi-arid environments, ED is therefore a valuable tool for regulating vine vigour and controlling canopy development, an effect similar to that which cover crops can exert in more humid environments (TrigoCórdoba et al. 2015).

The timing of water application as opposed to the amount of water applied, had a greater effect on yield and its components, since the less-irrigated treatment (SDI) was less affected than the ED and LD treatments in comparison to that of the Control. The SDI treatment, however, did not differ significantly from ED, LD, or from Control treatments in yield or cluster mass. In addition, water deficit during the pre-veraison period (ED) resulted in the greatest constraint to vineyard productivity, although results were not fully consistent among seasons (Table 5). This is because in 2013, the $S_{\Psi}$ experienced during the anthesis to veraison stage was not detrimental for any treatment (Table 3), even though the $\Psi_{\text {stem }}$ reached by ED was similar in every season (Figure 15). Conversely, in 2014, the $S_{\Psi}$ in 
the SDI treatment reached its highest level, and that season was the only one where the SDI treatment affected vine productivity detrimentally. Therefore, we can derive the threshold value of $S_{\Psi}$ between anthesis and veraison of $35 \mathrm{MPa}$ day which cannot be surpassed in order to maintain the full productivity potential of the vine. Additionally, yield reduction was partly due to the carry-over effect of the water stress on the number of clusters per shoot, as this parameter is determined during bud formation in the previous year. This significant effect was observed in every DI treatment (Table 5) and indicated the sensitivity of shoot fruitfulness of Muscat of Alexandria to water stress. Despite this effect not being clearly consistent across all the seasons, the Control treatment showed the highest value in every season (Figure 16). There was a large spatial variability in the vineyard, which could also explain the fact that even in the first year of the experiment, when there was no carryover effect, ED significantly decreased shoot fruitfulness, which cannot be explained by the treatments imposed. This is despite the statistical design employed having four EUs assigned considering the initial soil and vine spatial variation. A similar effect of irrigation on shoot fruitfulness was found in Tempranillo grapes by Esteban et al. (1999) as compared to rainfed crops. Conversely, Intrigliolo and Castel (2010) did not find this behaviour in a similar experiment, also in Tempranillo. Likewise, de Souza et al. (2003) and dos Santos et al. (2007) found no reduction in shoot fruitfulness between full and non-irrigated Muscat of Alexandria vines even though similar vine water stress was reached in their experiments as compared with the present one. This may suggest that this parameter is sensitive to another variable related to water stress severity and its timing; for instance, as Ferreyra et al. (2003) observed in Chardonnay, carbohydrate reserves, which can be depleted due to water stress. Regardless, the yield reduction observed in all DI treatments in our trial, significant (ED and $\mathrm{LD}$ ) or not (SDI), tended to be cumulative over the three seasons due to a decrease in the number of clusters per shoot and their mass as a consequence of smaller berry size. 
Significant reduction in berry mass due to ED and SDI indicate that the water stress imposed during the pre-veraison period was likely detrimental for berry cell expansion (Table 5). This suggests a lower sensitivity of fruitset than pericarp cell division to water stress, since both processes occur simultaneously. Such a result is consistent with the correlation found between $S_{\Psi}$ and berry mass by Baeza et al. (2007) in Cabernet Sauvignon and not between berries per cluster. Similar conclusions were also reported for Shiraz (McCarthy 1997), Cabernet Franc (Matthews and Anderson 1988), Tempranillo (Intrigliolo and Castel 2010) and for glasshouse-grown Pinot Noir and Riesling (Reynolds and Naylor 1994).

The higher yield-to-pruning mass ratio (Ravaz index) and lower LA-to-yield ratio were found as the result of less irrigation. These ratios obtained here, according to the optimal ones presented by Kliewer and Dokoozlian (2005) in Thompson Seedless, Tokay syn. Viura, Chenin Blanc and Cabernet Sauvignon (4 to 10 and 0.8 to $1.2 \mathrm{~m}^{2} / \mathrm{kg}$, respectively), suggest that in the present experiment the vines were over-cropped and incapable of producing high quality fruit. The crop levels obtained here, which according to the literature unbalance the vine, were similar to those presented by dos Santos et al. (2007) in Muscat of Alexandria. Due to the high flavour potential of this cultivar, the objective of the Muscat winegrower is to maximise productivity while reaching the target of $22{ }^{\circ} \mathrm{Brix}$ without many concerns about flavour maturity. In our trial, only in 2013, when the latest harvest took place (Figure 17), vines may have shown a mild source-to-sink limitation in every treatment. Presumably, this over-cropping affected bud formation, depleted vine reserves or blocked carbohydrates accumulation, since the period from postharvest until leaf fall, when the greatest increase of non-structural carbohydrates occurs (Williams and Smith 1991), was shorter. Therefore, in the following year, the clusters per shoot (Figure 16) and berry set, which are mainly controlled by the supply of metabolites to the clusters (Coombe 1959), were greatly reduced in all treatments compared to that of the previous 
seasons. Hence, this carry-over effect point to the threshold ratios for Muscat of Alexandria and are indicative of the high productivity potential of the cultivar. Therefore, for a correct ripeness, we can suggest values of Ravaz index and of LA-to-yield ratio ranging from 9 to 19 and 0.6 to $1.2 \mathrm{~m}^{2} / \mathrm{kg}$, respectively, as vines with a ratio above 21.8 and under $0.45 \mathrm{~m}^{2} / \mathrm{kg}$ were considered to be unbalanced.

We expected that the moderate water stress applied would have little effect on berry composition (Table 6) (Matthews and Anderson 1988, dos Santos et al. 2007). Furthermore, the difference in TSS and tartaric acid concentration between treatments was not fully consistent between seasons, mainly because there was no significant effect in 2013 . Nevertheless, TSS appeared to be inversely related to TA, as well as BM. These results agree with observations of Williams (2014) obtained in a Chardonnay vineyard under similar management practices. Thus, the ED treatment, which was more efficient than LD in reducing BM (Table 5) led to berries with a higher TSS and a lower TA (higher maturity index). The LD treatment, however, showed a non-significant reduction in BM as compared to that of the Control and reached a TSS and TA similar to that of the ED. Likewise, El-Ansary et al. (2005), in Muscat of Alexandria grafted onto SO4 rootstocks, found that as the vine water status decreased during the post-veraison stage, the TSS were increased and the TA decreased. This could be partly due to berry desiccation and/or to the reallocation of carbohydrates to the fruit as a response to the development of fewer lateral shoots (Reynolds and Naylor 1994), which otherwise would be competing for photoassimilates with grapes (Matthews and Anderson 1988, McCarthy 1997).

An increase found in TA and malic acid concentration as the irrigation volume increase is a common response (Williams and Matthews 1990, López et al. 2007), however, more specifically, the pre-veraison water deficit influenced the rate of malic acid catabolism. Tartaric acid concentration followed a less conclusive trend and was not consistent across the seasons. The overall increase in the metabolic activity of the berries may have been due 
to the effect of temperature and light intensity, as less dense canopies increase cluster exposure to direct solar radiation (Jackson and Lombard 1993, Intrigliolo and Castel 2010). In our trial, however, these effects were attenuated by the removal of $0.5 \mathrm{~m}^{2}$ per vine of the basal leaf without a statistical difference between treatments (data not shown). Notwithstanding, the significant but slight increase in the tartaric-to-malic acid ratio observed in musts of ED-treated vines could prove to be beneficial for wine stability, as malic is weaker than tartaric acid, resulting in a decrease in $\mathrm{pH}$.

Sugar accumulation during berry ripening was pushed forward in all the DI treatments as compared to that of the Control (Figure 17), but only during the two driest seasons, indicating that mild water stress did not prevent ripening. Even at high ripeness levels, in 2014, when TSS of DI was around 24ํㅜㄹix, these treatments maintained ripening similar to that of the Control. This could be partly explained by the influence of sink:source ratios, as has been reported for other grapevine cultivars (Bravdo et al. 1985, Poni et al. 1993).

\section{Conclusions}

Satisfying $50 \%$ of $\mathrm{ET}_{\mathrm{c}}(\mathrm{SDI})$ was sufficient to guarantee adequate vine water status for the entire season, providing that a $S_{\Psi}$ threshold of $35 \mathrm{MPa}$ day between anthesis and veraison, or from veraison to harvest, is not surpassed. Such an irrigation strategy avoids severe vine water stress assuring the high yield potential of Muscat of Alexandria. Therefore, water savings of $48 \%$ compared to the Control results in a non-significant reduction in yield while enhancing accumulation of grape sugar, leading to a much higher water-use efficiency (amount of fruit produced per unit of water applied) than that of the Control and the ED and LD treatments. Nevertheless, carry-over effects on productivity are not ruled out after the years when vines were over-cropped. Additionally, pre-veraison 
Chapter II. Regulated Deficit Irrigation

water stress was the period that most greatly impacted berry growth and shoot fruitfulness, besides enhancing early ripening by increasing TSS and reducing malic acid. In contrast, post-veraison water deficit is not recommended, as it reduced yield with little change of berry composition and resulted in low water savings. 
Chapter III

VINEYARD ROW'S ORIENTATION EFFECTS ON WATER-USE EFFICIENCY AND GRAPE COMPOSITION OF POTTED GRAPEVINES CVS. VERDEJO AND BOBAL 


\section{VINEYARD ROW'S ORIENTATION EFFECTS ON WATER-USE EFFICIENCY AND GRAPE COMPOSITION OF POTTED VERDEJO AND BOBAL AND GRAPEVINES}

\section{Introduction}

Grapevine water-use is linearly related to sunlight interception by the canopy (Williams and Ayars 2005). In crops which do not cover the entire soil surface and under no soil water limitations, the amount of dry matter produced by a canopy is a linear function of the amount of light intercepted (Monteith and Moss 1977, Grappadelli et al. 1994). In fact, it is the external leaf area which intercepts most of the radiation (Smart 1973). Shaded leaves do not contribute much to the vine carbon assimilation as they mostly receive light energy from diffuse radiation (Escalona et al. 2003). In fully developed canopies, the term intercepted radiation can be used as a simplification of absorbed radiation, disregarding the small percentage which represents reflected and transmitted radiation by the soil-plant (Baeza et al. 2010). For instance, Poni et al. (2003) observed that, for a given training system, the sunlight intercepted by vineyard canopy increases with leaf area up to a level beyond which leaf mutual shading hinders the increase of carbon assimilation potential. That is to say, there is a threshold leaf area in which the maximum canopy $\mathrm{CO}_{2}$ exchange rate is reached.

In viticulture, training systems and canopy management are used to modulate the vine radiation balance by affecting canopy geometry and solar radiation interaction. In this regard, vineyard canopy orientation plays a determinant role in the photosynthetically active radiation (PAR) and ultraviolet radiation (UV) intercepted and concomitant canopy physiological processes (Palmer 1989, Grifoni et al. 2008, Hunter et al. 2016, Campos et al. 2017). In the viticultural regions located between $30^{\circ}$ to $50^{\circ} \mathrm{N}$ and $30^{\circ}$ to $40^{\circ} \mathrm{S}$, solar radiation is not usually limiting for carbon assimilation. In fact, in absence of vine water stress, PAR increases photosynthesis until it reaches a saturation point (Baeza et al. 2010, Buckley et al. 2013). At this light intensity, the limiting factor is the leaves' internal concentration of $\mathrm{CO}_{2}$. Therefore, vine water status is the more probable variable that determines grapevine performance under Mediterranean climates (Williams and Matthews 1990). However, differences in transpiration rates among different training systems were recorded even in fully irrigated vines (Baeza et al. 2005). Thus, vineyard spacing, pruning and training system are of major importance in determining the photosynthetic capacity of 
the vine (Mabrouk and Sinoquet 1998). All of these factors indeed should be fine-tuned according to the specific cultivar, latitude and altitude, and soil water limitations.

In modern viticulture, vegetation is usually positioned vertically by means of metal wires and posts. In this manner, to ease mechanization, vineyards are generally planted in rows. The orientation criteria should follow the vineyard contours, aiming to prevent soil erosion. Nevertheless, as heavy machinery is used, the criterion of fewer turns of the tractor has been imposed, conditioning the width of vineyard inter-row. When the terrain is flat and the space not limiting, the north-south (NS) orientation is usually sought in order to facilitate uniform light distribution into the fruiting zone (Naylor et al. 2000, Tarara et al. 2005). Vertical hedgerow systems-oriented NS clearly equilibrates the radiation load over both canopy sides during the course of the day, with more light being intercepted at early morning and late afternoon and lower radiation interception at midday when the sun hits the narrow top of the canopy (Poni et al. 1999, Trentacoste et al. 2015).

Although on a seasonal basis there is a tight correlation between PAR interception and the whole canopy net $\mathrm{CO}_{2}$ exchange rate, at a daily time scale, canopy photosynthesis is not only based on the quantity and intensity of intercepted radiation, but also on the time of day in which radiation is intercepted (Poni et al. 2003). The diurnal trends of wholecanopy photosynthesis reach a maximum level before noon and subsequently decline progressively throughout the remain of the day. Moreover, Poni et al. (1999) stated that the whole-canopy transpiration rates during midday hours are more decreased in NS-oriented vines than in the $\mathrm{EW}$-oriented ones. In a similar experiment, also in potted vines, Intrieri et al. (1998) confirmed that water-use efficiency (WUE) was higher during the midday hours in NS rows, with little variability between EW and NS on a daily basis. Furthermore, Intrieri et al. (1996) observed, in field-grown grapevines, that the EW orientation reduced growth, yield and total dry matter per vine as compared to NS, NE-SW and NW-SE orientations. PAR absorption regulates the rate of carbon assimilation but also the cluster microclimate conditions within the vine, both affecting grape-ripening (Jackson and Lombard 1993, Bergqvist et al. 2001). In this sense, Hunter et al. (2016) observed that EW-orientated rows intercepted a lower radiation in the interior of the canopy than NS, but EW captured the largest portion of total radiation in the cluster zone due to the higher soil-reflected radiation.

The objective of this study was to unravel the effects of orienting vineyard trellises EW instead of the more usual NS orientation on vine water-use, WUE and grape 
composition. Our hypothesis was that under the Mediterranean climate, modulating sunlight radiation interception by the canopy could reduce vine water-use requirements. Thus, by orienting vineyard trellis systems EW, the radiation load could be reduced as compared to that of the NS-oriented vines, and consequently, vine transpiration may be reduced as well. As sunlight energy is not limiting in our conditions, yield might not be compromised by the reduction of solar radiation interception. For this purpose, an experiment was carried out for three seasons in fully irrigated potted-vines oriented NS and EW. The trial was conducted with two Spanish cultivars of different origin, traditionally cultivated either in Eastern Spain (Bobal, red cultivar) or Northern Spain (Verdejo, white cultivar). To the best of our knowledge, this is the first trial focusing on long term vine transpiration responses to the modification of sunlight interception through the vineyard row's orientations.

\section{Materials and methods}

Site and crop

The experiment was carried out from 2014 to 2016 in potted Vitis vinifera L. Bobal and Verdejo onto 110R at the Valencian Agriculture Research Institute (IVIA) experimental farm (Valencia, 39035'13.952”N, 023'54.005'W; elevation 68 m.a.s.l). At the beginning of the experiment, vines were three years old. The climate at the site was Mediterranean, with an average annual rainfall of $379 \mathrm{~mm}$ and reference evapotranspiration $\left(\mathrm{ET}_{\mathrm{o}}\right)$ of $1112 \mathrm{~mm}$. Climatic data were recorded at an automated meteorological station 100 m away from the plot. $\mathrm{ET}_{\mathrm{o}}$ was calculated with the Penman-Monteith formula (Allen et al. 1998).

Seventy-liter pots filled with a mix of coconut fibre substrate and compost were used. Pots were covered with silver plastic in order to minimize heating and water evaporation from the substrate. Vines were located outdoors at a spacing of $2.5 \mathrm{~m} \times 2 \mathrm{~m}$, with the first and the last vines of each row acting as guards (Figure 18). The vines were winter-pruned to about 10 spurs per vine and 2 nodes per spur on a bilateral Royat cordon and trained into a vertical trellis system. Cluster thinning was applied during flowering in order to equilibrate leaf area-to-yield, since initial shoot fruitfulness was too high. Shoot thinning was performed before flowering when shoots reached a height of approximately 2 $\mathrm{m}$. The final hedgerow was a continuous $0.2-0.3 \mathrm{~m}$ in width. The pots were drip irrigated to avoid substrate water restrictions during the whole season. Irrigation scheduling was the same in both cultivars and aimed to ensure some drainage after each water application. 
Irrigation was applied 3 to 5 times per day through 3 pressure-compensated emitters at a rate of 3.8 $\mathrm{L} \mathrm{h}^{-1}$ per plant. Vines were fertigated (30-20-60-7.5 kg.ha-1 of N, $\mathrm{P}_{2} \mathrm{O}_{5}, \mathrm{~K}_{2} \mathrm{O}$, and $\mathrm{MgO})$.

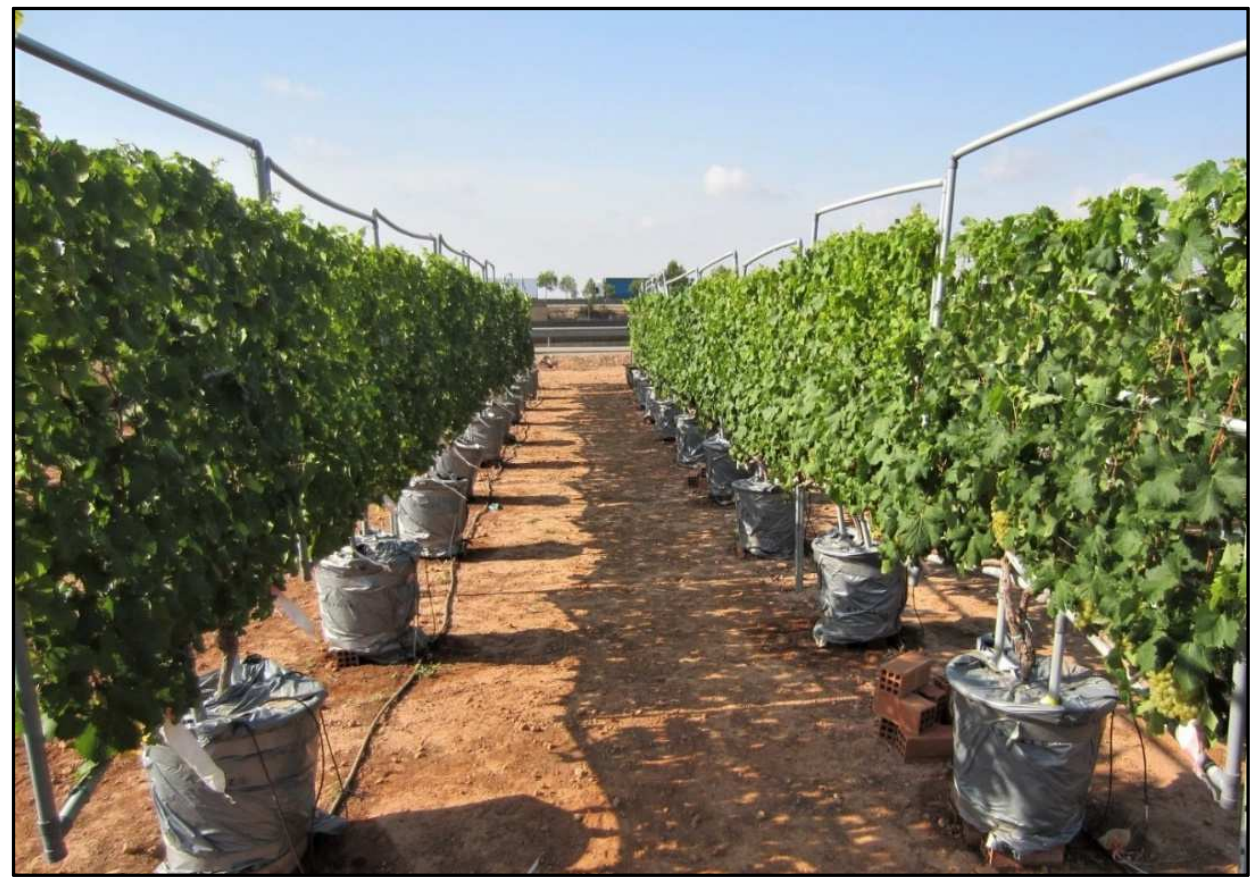

Figure 18. Potted drip-irrigated vines covered with silver plastic in a vertical shoots positioned trellis system orientated NS in the first season (2014). Canopy size was approximately $2 \mathrm{~m} \times 2 \mathrm{~m}$.

Vineyard trellis system orientation treatments

In each cultivar, two vertical shoot positioned trellis systems orientations were tested 1) north-south (NS) and 2) east-west (EW). During the first season, each treatment consisted of 10 vines per cultivar and vineyard orientation, 20 vines per treatment during the subsequent seasons. Each experimental unit (EU) consisted of 5 vines every season. The external vines of the row acted as borders.

\section{Field determinations}

Vine phenology was monitored weekly during the whole season in two shoots per vine. At veraison, the percentage of coloured berries was determined in two clusters per vine. Vegetative growth seasonal variation was determined monthly in a sample of 4 shoots per vine by measuring primary and secondary shoots length. After thinning, trimming and pruning, the vegetative tissue fresh mass was weighted for each vine. Dry matter was calculated by discarding the moisture weight as determined by heating fresh weight 
samples at $60{ }^{\circ} \mathrm{C}$ for one week. Leaf area was estimated from allometric relations between shoot length and leaf area per shoot, measured with a LI-3100C Area Meter (LI-COR Bioscience, Nebraska, USA), separating main and lateral shoots. These relations were obtained from samples of 10 shoots of different vigour for each cultivar and season. Total leaf area (LA) was determined as the one-sided green leaf area after harvest in each experimental vine by measuring each main and secondary shoot length. LA-to-yield ratio was calculated in all experimental vines.

In 2014, daily vine water-use was obtained by weighing all the individual pots at 7:00 solar time for two consecutive days in 5 occasions. Additionally, pots were also weighted at solar noon in order to obtain separate morning and afternoon transpirations. During these determinations, manual irrigation was applied to each pot $(1+1 \mathrm{~L})$ in order to prevent vine water stress while monitoring for the absence of drainage. For total vine water-use estimation, the daily transpiration values obtained by weighing were extrapolated to the subsequent days until the next measurement was taken. In 2015, a drainage collector system was built with a reservoir and a water meter per each five vines (Figure 19). Therefore, during the 2015/16 seasons, water-use was estimated weekly by water balance. Water balance was calculated as the difference between the irrigation volume measured by the water meters and the water volume drained to the reservoir. The variation in the substrate water content was disregarded. WUE was estimated as the ratio between yield and the amount of water calculated by the average daily water balance between the measuring dates (Hsiao et al. 2007). Therefore, the absolute values of wateruse and WUE will not be comparable among seasons, as the measuring period was not exactly the same. In 2014, the water balance was calculated for each experimental vine from the $1^{\text {st }}$ of June to the end of July, while in 2015 it was calculated for each reservoir ( 5 vines) from the $7^{\text {th }}$ of July to $7^{\text {th }}$ of September, and in 2016 from the $1^{\text {st }}$ of April until the end of August for Bobal, and until the $23^{\text {rd }}$ of September for Verdejo. 


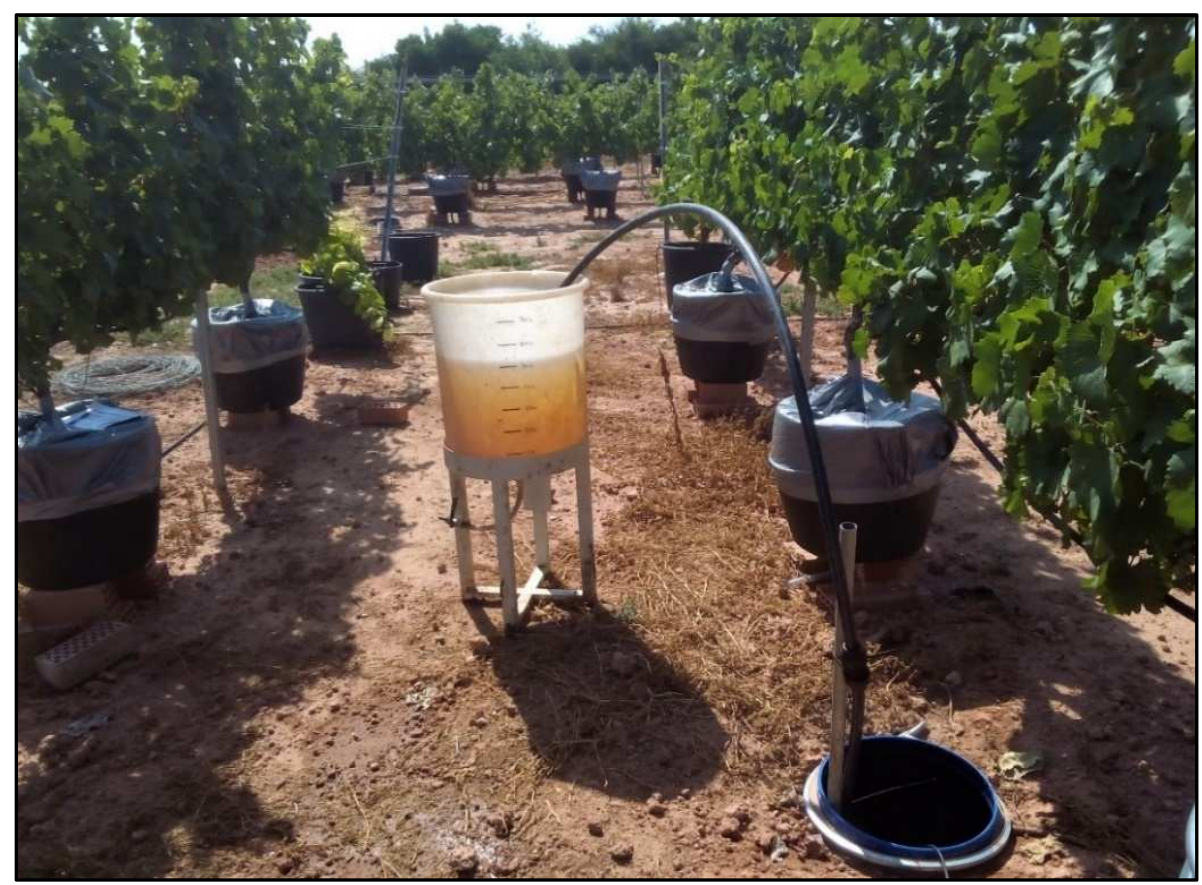

Figure 19. Emptying and measuring the water volume of the underground drainage collector system, which included a reservoir per each five vines during seasons 2015 and 2016.

Vine water status was determined monthly. Measurements were performed at predawn in un-bagged leaves $\left(\Psi_{\text {pd }}\right)$, and at midday in bag-covered leaves $\left(\Psi_{\text {stem }}\right)$. Water potential was measured with a Scholander pressure chamber (Model 600, PMS Instrument Company, USA) on 1 leaf per plant from 2 vines per EU. Additionally, stomatal conductance, net photosynthesis and transpiration rates were determined at leaf level by means of a portable IRGA gas exchange analyzer (LCpro+, ADC BioScientific Ltd., England). Gas exchange was assessed in 2 vines per EU and cultivar in the same dates and vines when water potential determinations were conducted. Measurements were taken in two basal and mature leaves per vine of the sun-exposed side of the canopy, attempting not to modify the natural leaf arrangement. In 2014, these measurements were carried out coinciding with the date of pot-weighing. The timing of measurement was between 7:00-9:00, 11:0013:00 and 16:00-18:00 during the morning, midday and afternoon hours, respectively.

Vine yield, number of clusters per vine and average cluster weight were determined at harvest on each experimental vine. Additionally, the number of berries per cluster was determined from samples of one cluster per vine. Fresh berry mass was determined from random samples of 200 berries per EU at harvest. 


\section{Laboratory determinations}

Berry composition at harvest was determined from the sampled berries for berry mass determination. In Verdejo, the 200 berries were crushed with a blender (Thermomix, Vorwerk, Wuppertal, Germany) and hand pressed through a metal screen filter and used to evaluate technologically-defined maturity. In Bobal, 125 berries were used for technological analysis and 75 were kept for phenolic maturity assessment. The juice's total soluble solids (TSS) was determined by refractometry (PR-101, Series Palette, Atago Co, LTD, Japan), pH and titratable acidity (TA) where measured by an automatic titrator (Metrohm, Herisau, Switzerland). Must was titrated with a $0.1 \mathrm{~N}$ solution of $\mathrm{NaOH}$ to a $\mathrm{pH}$ end point of 8.2; results being expressed in tartaric acid equivalents. The maturity index was calculated at harvest as the Total Soluble Solids-to-titratable acidity ratio (Kliewer and Weaver 1971)

The berries used for phenolic composition determination were homogenized with a blender (Ultraturrax T25, IKA-Werke GmbH \& Co. KG, Staufen, Germany). The resultant paste was diluted in $\mathrm{HCl}$ media for measuring the optical density (OD; $\mathrm{nm}$ ) by spectrophotometric methods (Ati-Unicam UV-4); total anthocyanins and total polyphenols index (TPI) were calculated according to Ribereau-Gayon et al. (2000). All laboratory determinations were duplicated.

\section{Statistical analysis}

Data analysis was performed using "Statgraphics Centurion XVI" package version 16.0.07 by two-way analysis of variance (ANOVA) to assess the significance of treatments effects, repetitions, seasons and their interaction. In addition, the "environmental mean" of the daily transpiration across seasons, cultivars and treatments was calculated. This method has been widely used in different crops for analyzing water relations traits (Sadras et al. 2009). Significant deviations around the $y=x$ line by the two-way ANOVA would thus indicate significant effects of the treatment and cultivar. The slopes of the regression between transpiration of each treatment per cultivar and the environmental mean indicate the effect of orientation on the plasticity of the trait (Sadras and Richards 2014).

\section{Results}

During the experimental seasons, the $\mathrm{ET}_{\mathrm{o}}$ was 1320,1268 and $1268 \mathrm{~mm}$, for 2014 , 2015 and 2016, respectively. The maximum daily $\mathrm{ET}_{0}$ values during the three seasons ranged between 8.4 and $10.2 \mathrm{~mm}$, corresponding with maximum temperatures over $40 \stackrel{\circ}{\mathrm{C}}$ 
(Figure 20). Daily radiation during the core of the season (1 $1^{\text {st }}$ of April to $31^{\text {st }}$ of August) was seasonally very stable at $25 \mathrm{MJ} \mathrm{m}^{-2}$ in the three years studied, corresponding to $51.5 \mathrm{~mol}$ PAR $\mathrm{m}^{-2}$.

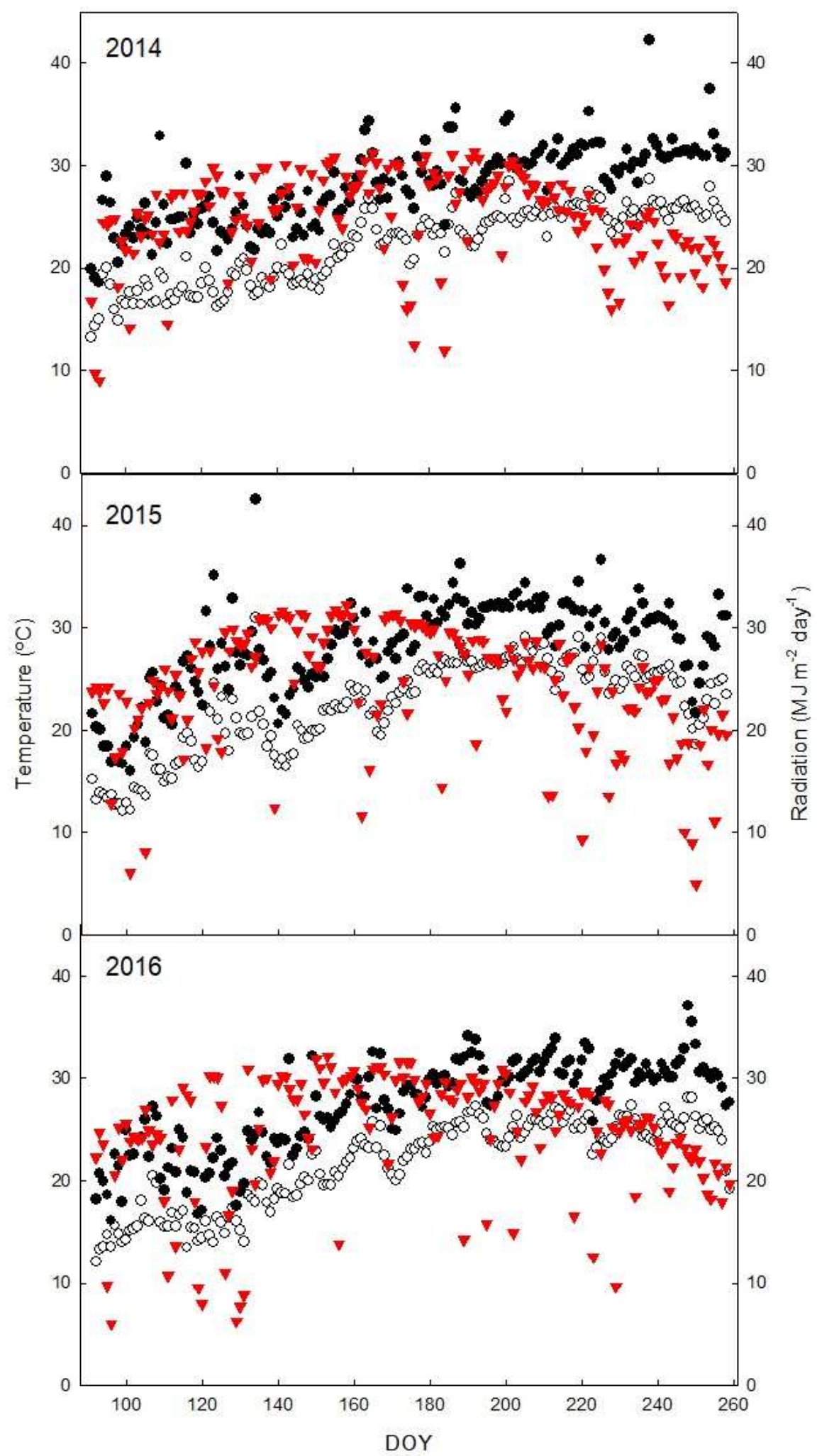


Figure 20. Seasonal patterns of the daily maximum air temperature $(\bullet)$, mean air temperature (o) and incoming solar radiation ( $\boldsymbol{\nabla})$ in Moncada, Valencia, Spain. The day of year (DOY) follows a continuous annual-time scale from $1^{\text {st }}$ of April to $15^{\text {th }}$ of September.

Budburst during the experiment took place approximately in the second week of March in Verdejo (DOY 67-73) and during the fourth in Bobal (DOY, 88-94). Verdejo phenology was not significantly affected by the treatments imposed, but Bobal phenology was advanced in the NS orientation compared to the EW (Figure 21). Although, this advancement in the phenological stages was reduced as the season progressed. Figure 21, shows the Bobal phenology evolution until veraison, when the percentage of coloured berries per cluster is shown. A similar behaviour was found for shoot development in Bobal, in which vegetative growth was anticipated in NS as compared to EW. Figure 22 shows the mean accumulated growth of the main and secondary shoots for Bobal and Verdejo in 2016 before shoot trimming was performed.

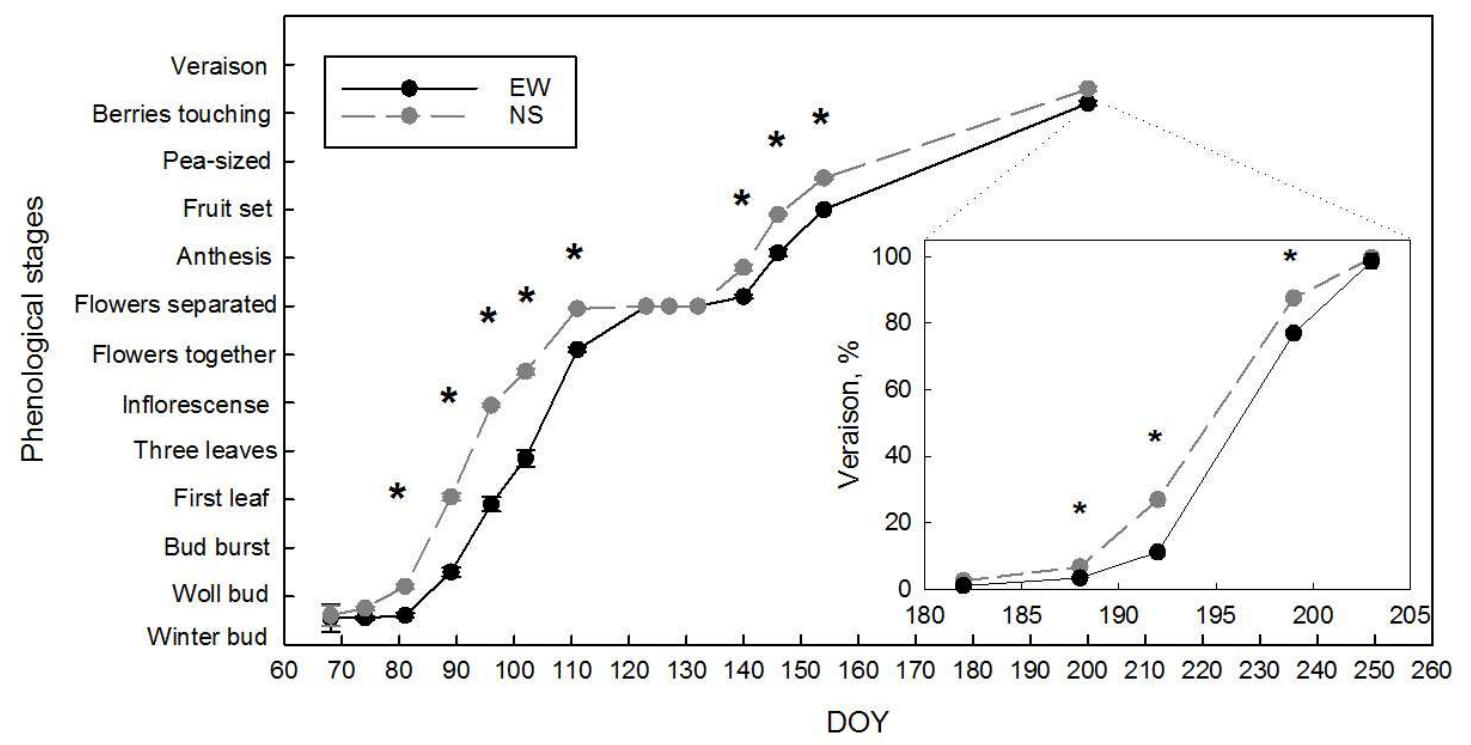

Figure 21. Bobal phenology in north-south (NS; •) and east-west (EW; •) vineyard row's orientation during 2016. The percentage of coloured berries is depicted for the 2014 season. Data are averages and standard errors of two shoots per vine $(n=40)$. Asterisks denotes significant difference at $\mathrm{p}<0.05$. DOY, day of the year.

Vegetative development was significantly affected by the season in both cultivars (Table 7). The number of shoots per treatment did not show any differences among treatments as the pruning and thinning criteria were the same. Pooling data across seasons, total dry matter was significantly increased by the NS orientation as compared to the EW in Bobal but not in Verdejo. Notwithstanding, pooling data from all the seasons, Verdejo total 
leaf area (LA) was significantly increased by the EW orientation in comparison to NS. On the other hand, in Bobal, the LA was unaffected. However, in both cultivars, an interaction between season and treatment was found for LA. Moreover, in both cultivars, on a seasonal average basis, the LA-to-yield ratio was unaffected. However, the LA-to-yield ratio was differently affected in some seasons. Remarkably, in Bobal in 2015 and in Verdejo in 2016, the values of LA-to-yield ratio suggest that vines were over-cropped (Kliewer and Dokoozlian 2005). In these seasons, the LA-to-yield ratio was significantly reduced by EW in both cultivars (Table 7).

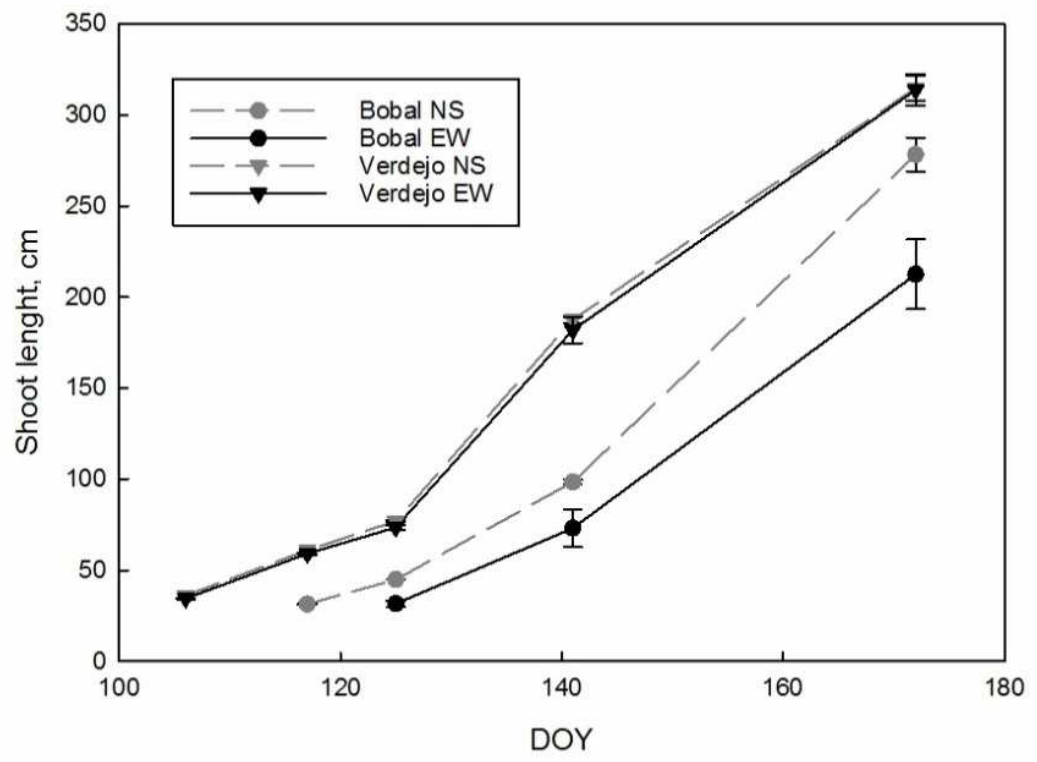

Figure 22. Shoot length (principal + secondary) in Bobal north-south (NS; $\bullet$ ) and east-west (EW; •) and of Verdejo in north-south (NS; $\nabla$ ) and east-west (EW; $\nabla$ ) vineyard row's orientation of Verdejo and Bobal during 2016. Data are averages and standard errors of 4 shoots per vine $(n=80)$. DOY, day of the year.

Table 7. Vegetative development, leaf area-to-yield ratio, water-use, water-use relative to leaf area and water-use efficiency in north-south and east-west vineyard row's orientation in Bobal and Verdejo potted vines during three seasons.

\begin{tabular}{|c|c|c|c|c|c|c|c|c|c|}
\hline Cultivar & Season & Orientation & $\begin{array}{c}\text { Shoot } \\
\text { number } \\
\text { vine }^{-1}\end{array}$ & $\begin{array}{c}\text { Dry } \\
\text { matter, } \\
\text { g vine }^{-1}\end{array}$ & $\begin{array}{c}\mathbf{L A}, \\
\mathbf{m}^{2} \\
\text { vine }^{-1}\end{array}$ & $\begin{array}{l}\text { LA-to- } \\
\text { yield, } \\
\text { m }^{2} \mathbf{k g}^{-1}\end{array}$ & $\begin{array}{c}\text { WU, } \\
\text { L vine }^{-1} \\
\text { day }^{-1}\end{array}$ & $\begin{array}{c}\text { Relative } \\
\text { WU, L } \mathbf{~ m}^{-2} \\
\text { day }^{-1}\end{array}$ & $\begin{array}{l}\text { WUE, } \\
\text { kg m}^{-3}\end{array}$ \\
\hline \multirow{7}{*}{ Bobal } & \multirow{2}{*}{2014} & NS & 17.0 & 482 & 6.3 & 2.6 & $9.2 \mathrm{a}$ & $1.87 \mathrm{a}$ & $4.3 \mathrm{~b}$ \\
\hline & & EW & 17.6 & 453 & 6.7 & 2.4 & $7.8 \mathrm{~b}$ & $1.19 \mathrm{~b}$ & $6.4 \mathrm{a}$ \\
\hline & \multirow{2}{*}{2015} & NS & 17.2 & $635 a$ & 5.0 & $0.5 a$ & 8.1 & $0.95 a$ & $19.7 \mathrm{~b}$ \\
\hline & & EW & 18.0 & $572 \mathrm{~b}$ & 4.9 & $0.4 \mathrm{~b}$ & 7.1 & $0.74 \mathrm{~b}$ & $25.2 \mathrm{a}$ \\
\hline & \multirow{2}{*}{2016} & NS & 18.2 & $893 a$ & $7.4 \mathrm{~b}$ & 1.8 & 9.4 & 0.98 & 4.9 \\
\hline & & EW & 18.4 & $671 \mathrm{~b}$ & $6.2 \mathrm{a}$ & 1.4 & 8.2 & 1.02 & 5.0 \\
\hline & Average & NS & 17.5 & $670 a$ & 6.2 & 1.6 & 8.9a & 1.3 & $9.7 \mathrm{~b}$ \\
\hline
\end{tabular}




\begin{tabular}{|c|c|c|c|c|c|c|c|c|c|}
\hline & EW & 18.0 & $565 b$ & 5.9 & 1.4 & $7.7 \mathrm{~b}$ & 1.0 & $12.2 \mathrm{a}$ \\
\hline & & Treatment & 0.093 & 0.000 & 0.142 & 0.171 & 0.005 & 0.063 & 0.002 \\
\hline & & Season & 0.030 & 0.000 & 0.000 & 0.000 & 0.041 & 0.014 & 0.000 \\
\hline & & $\mathrm{T} \times \mathrm{S}$ & 0.686 & 0.002 & 0.007 & 0.588 & 0.950 & 0.123 & 0.006 \\
\hline \multirow{11}{*}{ Verdejo } & \multirow{2}{*}{2014} & NS & 17.7 & 503 & 6.1 & 3.5 & $9.4 \mathrm{a}$ & $1.30 \mathrm{a}$ & $3.6 b$ \\
\hline & & EW & 17.5 & 579 & 6.7 & 4.1 & $8.2 \mathrm{~b}$ & $0.85 b$ & $6.3 a$ \\
\hline & \multirow{2}{*}{2015} & NS & 17.9 & 755 & $5.3 b$ & $1.2 \mathrm{a}$ & 8.1 & $0.99 a$ & 2.0 \\
\hline & & EW & 16.9 & 782 & $7.1 \mathrm{a}$ & $1.7 \mathrm{~b}$ & 7.8 & $0.75 b$ & 2.0 \\
\hline & \multirow{2}{*}{2016} & NS & 18.2 & 1019 & 8.4 & $0.5 \mathrm{a}$ & 11.1 & 1.06 & 2.9 \\
\hline & & EW & 18.0 & 1025 & 8.0 & $0.4 \mathrm{~b}$ & 10.4 & 1.11 & 2.5 \\
\hline & \multirow{5}{*}{ Average } & NS & 18.0 & 852 & $6.9 \mathrm{~b}$ & 1.2 & 9.5 & 1.3 & $2.8 \mathrm{~b}$ \\
\hline & & EW & 17.6 & 873 & $7.5 a$ & 1.3 & 9.0 & 1.2 & $3.5 \mathrm{a}$ \\
\hline & & Treatment & 0.085 & 0.593 & 0.006 & 0.494 & 0.220 & 0.217 & 0.001 \\
\hline & & Season & 0.054 & 0.000 & 0.000 & 0.000 & 0.000 & 0.000 & 0.000 \\
\hline & & $\mathrm{T} \times \mathrm{S}$ & 0.334 & 0.521 & 0.000 & 0.073 & 0.955 & 0.737 & 0.000 \\
\hline
\end{tabular}

For each parameter, data are average values of 5 vines per experimental unit. Within each season and cultivar, different letters mean significant differences at $p<0.05$. The statistical significance effect of the treatment $(\mathrm{T})$, season $(\mathrm{S})$ and their interaction are also indicated. Dry matter (vegetative parts after trimming and pruning); LA, total leaf area; WU, wateruse; WUE, water-use efficiency (yield/water transpired). Treatments are: NS, north-south and EW, east-west vineyard trellis system.

Vines were over-irrigated during the whole season every year, ensuring leaching after each irrigation event. Vine water potential evolution during the seasons confirmed that vines did not suffer from water stress. As an example, the $\Psi_{\text {pd }}$ and $\Psi_{\text {stem }}$ evolution during 2016 is depicted in Figure 23. Values of $\Psi_{\text {pd }}$ never fell below -0.25 MPa or - $0.75 \mathrm{MPa}$ of $\Psi_{\text {stem. }}$. Moreover, the treatments imposed provoked slight differences in vine water status. In both cultivars, $\Psi_{\text {stem }}$ was lower (more negative) in vines-oriented NS than in EW, without differences in $\Psi_{\text {pd }}$. The slight differences were more noticeable in Verdejo than in Bobal, but they were clearly observed in both cultivars and seasons. 


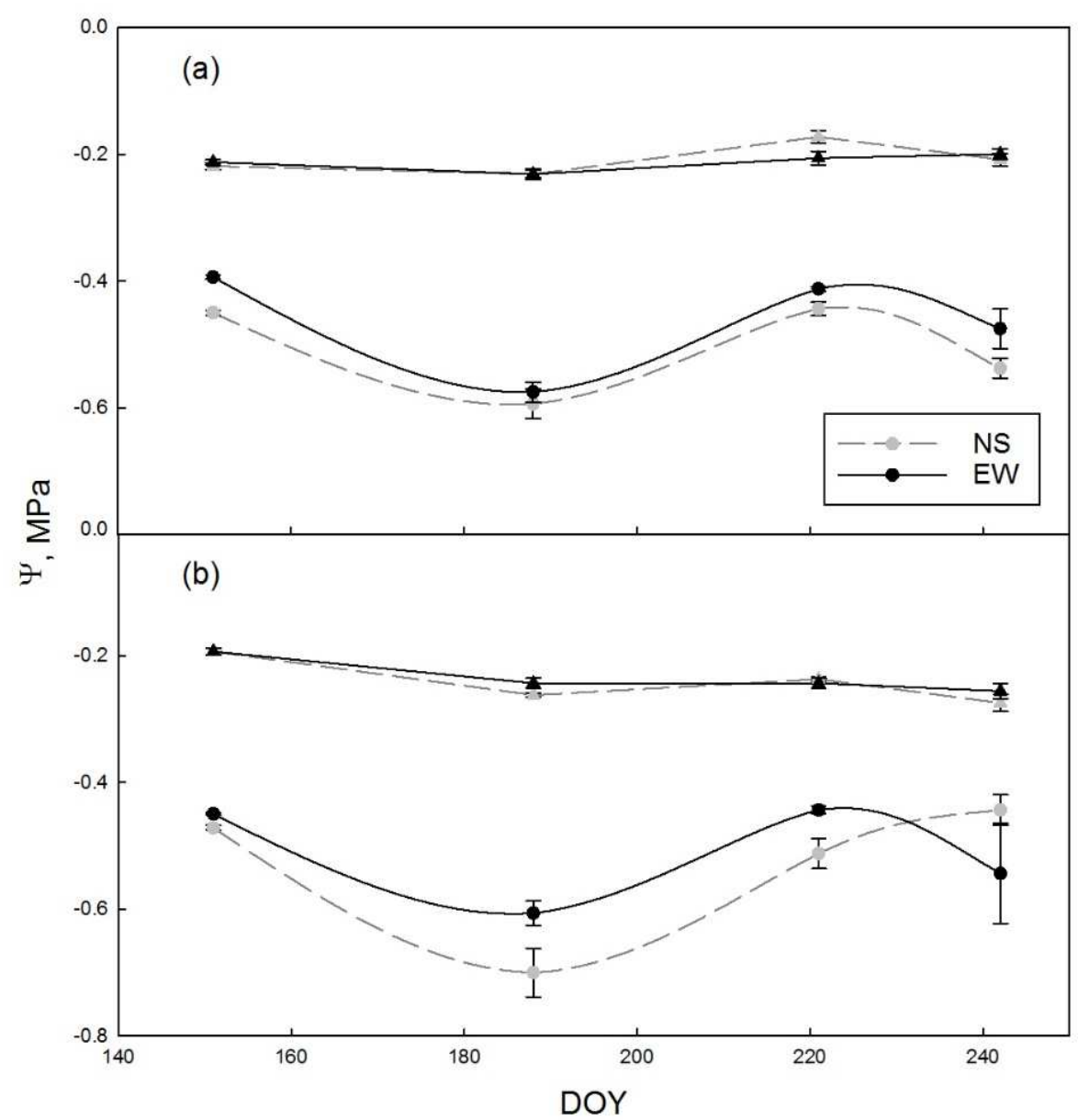

Figure 23. Vine water status evolution during the 2016 season in north-south (NS) and east-west (EW) vineyard row's orientation in Bobal [(a)] and Verdejo [(b)] cultivars. Data are averages and standard errors of 2 leafs per experimental unit $(n=8)$ for the predawn leaf water potential $(\nabla, \boldsymbol{\nabla})$ and midday stem water potential $(\bullet, \bullet)$. DOY, day of the year.

In both cultivars, during the first season, vine water-use was significantly reduced in the EW orientation compared to the NS (Table 7). Nonetheless, the transpiration reductions measured during 2015 and 2016 did not result to be statistically-significant. Pooling data across seasons, water-use was only significantly affected in Bobal. Regardless, pooling data across seasons, the EW row orientation resulted in transpiration reductions by $13 \%$ in Bobal and $7 \%$ in Verdejo compared to NS. Vine water-use seasonal variations during the three seasons are depicted in Figure 24. For both cultivars, the peak transpiration rates were recorded in July, decreasing from August to September. During the first season, it was observed that vine transpiration differences between orientations occurred both in the morning and in the afternoon (Figure 25). Particularly in Bobal during the afternoon, the difference in transpiration was noticeably greater. Interestingly, in both cultivars in 2014 and 2015, vine water-use relative to leaf area was significantly higher in the NS orientation 
than in EW. Nevertheless, pooling data within a season, differences were not statistically significant. Moreover, in both cultivars, the EW row orientation significantly increased WUE as compared to the NS orientation. This effect was clearly observed for Bobal in every season, while in Verdejo it was detected only in the first season. In 2016, in Verdejo, the significant yield reduction occurred in the EW due to impaired WUE.

Table 8. Leaf gas exchange parameters of Bobal and Verdejo potted-vines orientated in rows towards north-south (NS) or east-west (EW) pooled across three seasons.

\begin{tabular}{|c|c|c|c|c|c|}
\hline Cultivar & Season & Orientation & $\begin{array}{c}\mathrm{E}(\mathrm{mmol} \\
\left.\mathrm{H}_{2} \mathrm{O} \mathrm{m}^{-2} \mathrm{~s}^{-1}\right)\end{array}$ & $\begin{array}{c}g_{s} \\
\left(\mathrm{mmol} \mathrm{m}^{-2} \mathrm{~s}^{-1}\right)\end{array}$ & $\begin{array}{c}\mathrm{A} \\
\left(\mu \mathrm{mol} \mathrm{CO} 2 \mathrm{~m}^{-2} \mathrm{~s}^{-1}\right)\end{array}$ \\
\hline \multirow{11}{*}{ Bobal } & \multirow{2}{*}{ Morning } & NS & 3.1 & 197 & 11.5 \\
\hline & & EW & 3.4 & 211 & 11.3 \\
\hline & \multirow{2}{*}{ Midday } & NS & 3.4 & 205 & 10.1 \\
\hline & & EW & 3.3 & 211 & 10.2 \\
\hline & \multirow{2}{*}{ Afternoon } & NS & $2.6 \mathrm{a}$ & $208 a$ & $10.0 \mathrm{a}$ \\
\hline & & EW & $2.0 \mathrm{~b}$ & $146 \mathrm{~b}$ & $6.7 \mathrm{~b}$ \\
\hline & \multirow{5}{*}{ Daily } & NS & 3.2 & $257 a$ & $10.8 \mathrm{a}$ \\
\hline & & EW & 3.0 & $207 \mathrm{~b}$ & $9.7 \mathrm{~b}$ \\
\hline & & Treatment & 0.114 & 0.001 & 0.026 \\
\hline & & Season & 0.000 & 0.001 & 0.041 \\
\hline & & $\mathrm{T} \times \mathrm{S}$ & 0.374 & 0.379 & 0.469 \\
\hline \multirow{11}{*}{ Verdejo } & \multirow{2}{*}{ Morning } & NS & 3.1 & $290 a$ & $11.8 \mathrm{a}$ \\
\hline & & EW & 3.3 & $227 \mathrm{~b}$ & $10.5 b$ \\
\hline & \multirow{2}{*}{ Midday } & NS & 3.3 & 200 & 10.3 \\
\hline & & EW & 3.0 & 160 & 9.4 \\
\hline & \multirow{2}{*}{ Afternoon } & NS & 2.5 & 185 & 9.2 \\
\hline & & EW & 2.2 & 163 & 7.9 \\
\hline & \multirow{5}{*}{ Daily } & NS & 3.1 & $234 a$ & $10.8 \mathrm{a}$ \\
\hline & & EW & 3.0 & $199 b$ & $9.9 \mathrm{~b}$ \\
\hline & & Treatment & 0.298 & 0.002 & 0.039 \\
\hline & & Season & 0.000 & 0.000 & 0.076 \\
\hline & & $\mathrm{T} \times \mathrm{S}$ & 0.136 & 0.043 & 0.060 \\
\hline
\end{tabular}

For each parameter, data are average values of 4 leafs per experimental unit and date of measurement during 2014/16. Within each timing and cultivar, different letters mean significant differences at $p<0.05$. The statistical significance effect of the treatment (T), season (S) and their interaction are also shown. E, transpiration; $\mathrm{g}_{\mathrm{s}}$, stomatal conductance; A, net photosynthesis. Treatments are: NS, north-south and EW, east-west vineyard row's orientation. 


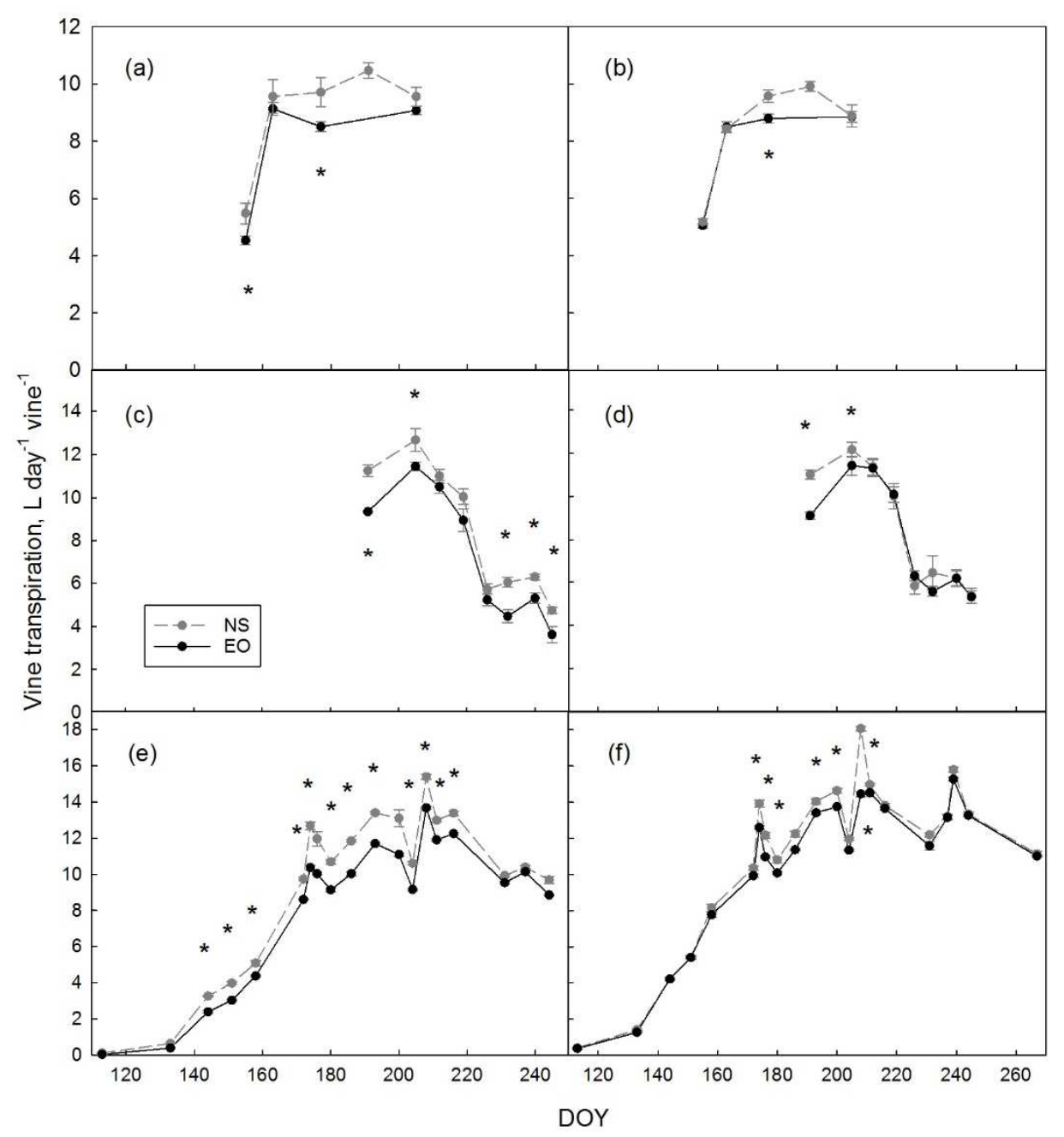

Figure 24. Seasonal transpiration of Bobal (left) and Verdejo (right) potted vines in northsouth (NS; •) and east-west (EW; •) vineyard row's orientation in 2014 [(a) and (b)], 2015 [(c) and (d)] and 2016 [(e) and (f)]. Data are averages and standard errors of 5 vines per experimental unit and date in $2014(\mathrm{n}=10)$, and of 4 experimental units per treatment in 2015 and $2016(\mathrm{n}=4)$. Asterisks denotes significant difference at $p<0.05$. DOY, day of the year.

Single leaf gas exchange measurements pooled across seasons (Table 8) did not perfectly agree with the whole-canopy transpiration measurements (Figure 24). Nevertheless, in both cultivars, the higher water transpiration determined at leaf level (E) in the NS row orientation in comparison to EW was consistent with whole vine water-use determinations. However, the differences found at a leaf basis resulted statistically significant only in Bobal during the afternoon. Moreover, the seasonal averages of stomatal conductance $\left(\mathrm{g}_{\mathrm{s}}\right)$ and net photosynthesis $(\mathrm{A})$ for both cultivars were significantly higher in NS than in EW (Table 8). This effect was more clearly observed during the morning in Verdejo, and during the afternoon in Bobal. At midday, gas exchange parameters did not 
show significant differences between treatments in any of the evaluated parameters by gas exchange.

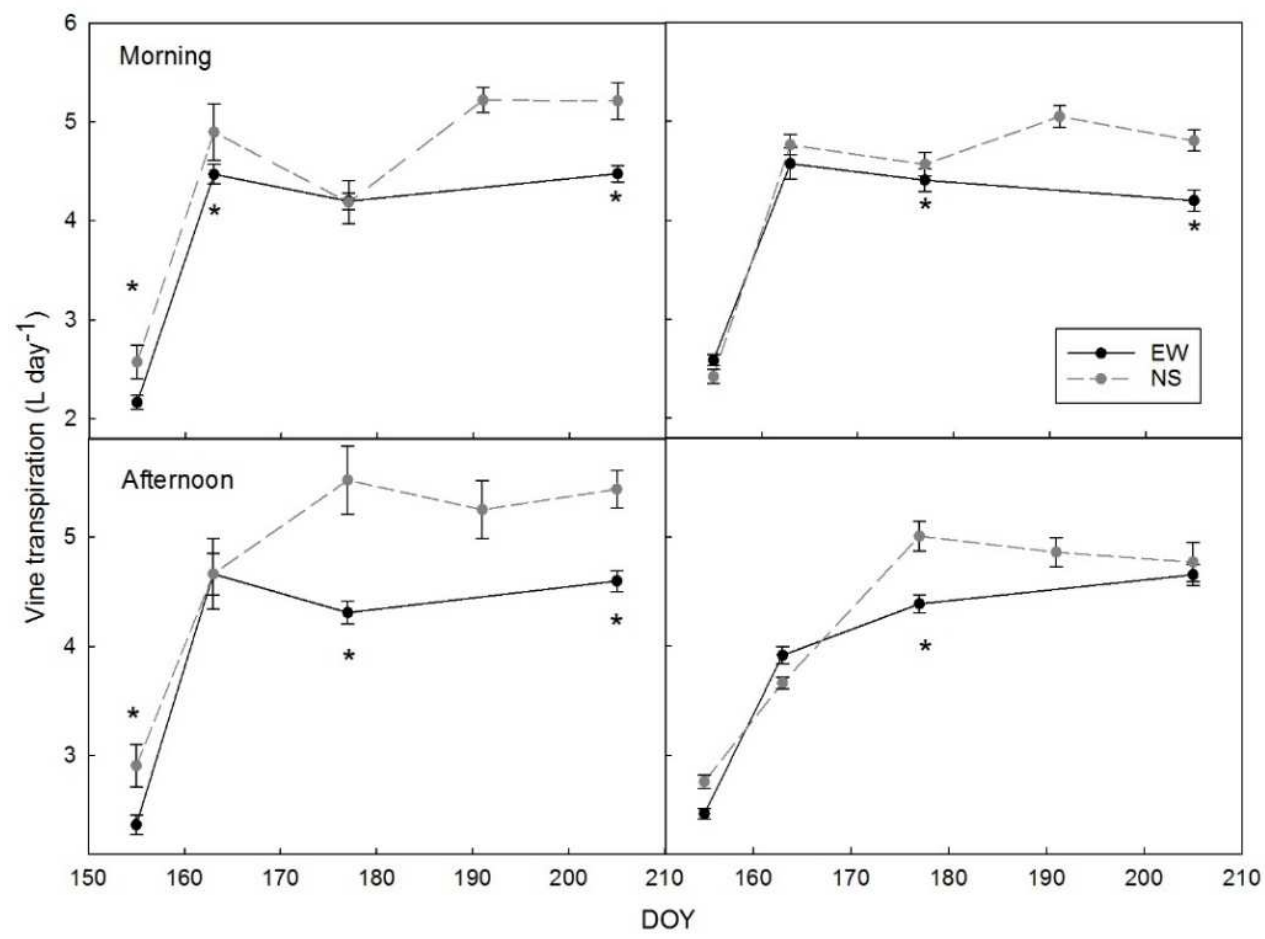

Figure 25. Daily transpiration (morning on the top of the figure and afternoon, on the bottom) of Bobal (left) and Verdejo (right) potted vines in north-south (NS; •) and eastwest (EW; •) vineyard row's orientation in 2014. Data are averages and standard errors of the weight loss of 5 vines per experimental unit and date in $2014(\mathrm{n}=10)$. Asterisks denotes significant difference at $p<0.05$. DOY, day of the year.

The plasticity of grapevine transpiration in response to vineyards row's orientation was assessed by analysing the regressions residuals of each treatment with the transpiration environmental mean (Figure 26). The effect was significant for both cultivar and orientation factors $(\mathrm{p}<0.0001)$, although an interaction effect was found between the two experimental factors $(\mathrm{p}<0.04)$. This could be due to the Bobal transpiration response to row orientation being greater than Verdejo's, although EW had significantly reduced transpiration in both cultivars. 


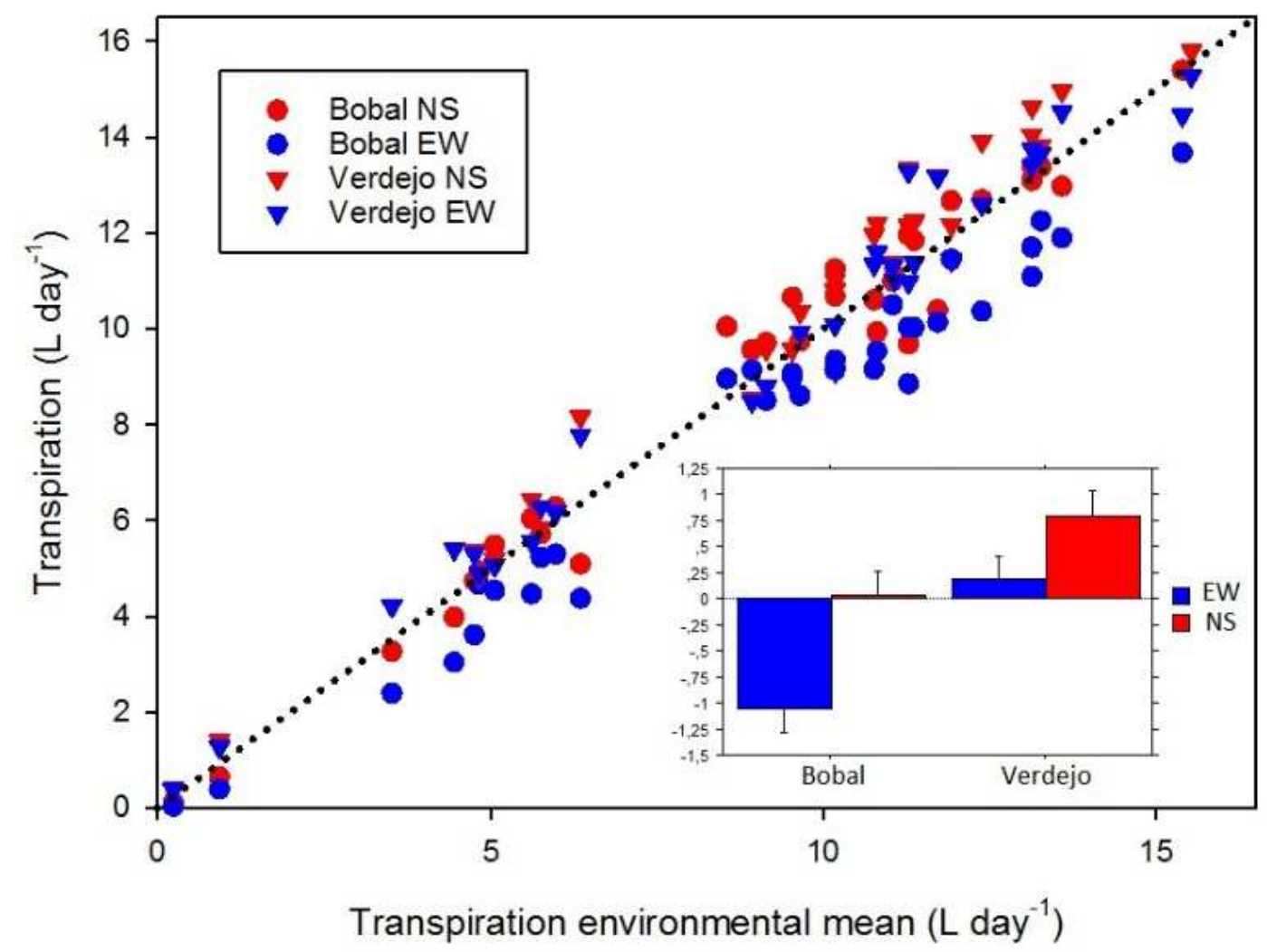

Figure 26. Scatter plot relating potted-vines daily transpiration of Bobal in north-south (NS; -) and east-west (EW; •) and of Verdejo in north-south (NS; $\boldsymbol{\nabla}$ ) and east-west (EW; $\boldsymbol{\nabla}$ ) vineyard row's orientation in 2014/16. Data are averages of 5 vines per experimental unit and treatment in $2014(\mathrm{n}=10)$, and of 4 experimental units per treatment in 2015 and 2016 $(\mathrm{n}=4)$. Bar chart shows significant deviation of each treatment and cultivar (mean and standard error) around the $\mathrm{y}=\mathrm{x}$ line.

Yield and its components were significantly variable across seasons but without showing a significant effect on the response to the treatments imposed (Table 9). Overall, in both cultivars, yield was unaffected by row orientation. Only as an exception, Bobal yielded higher in the EW orientation than in the NS orientation in 2015 and Verdejo yielded lower in EW orientation than in NS one in 2016. In both cultivars, the number of clusters per vine, berries per cluster and cluster mass were similar among treatments. Nevertheless for Verdejo, in all seasons, berry mass was significantly increased by the EW orientation as compared to the NS one. For Bobal, this berry mass increase was only observed in 2014 (Table 9). 
Table 9. Yield components of potted-vines in rows oriented north-south (NS) and east-west (EW) in Bobal and Verdejo grapevines during three seasons.

\begin{tabular}{|c|c|c|c|c|c|c|c|}
\hline Cultivar & Season & Orientation & $\begin{array}{c}\text { Yield, kg } \\
\text { vine }^{-1}\end{array}$ & $\begin{array}{c}\text { Clusters } \\
\text { vine }^{-1}\end{array}$ & $\begin{array}{c}\text { Cluster } \\
\text { weight, g }\end{array}$ & $\begin{array}{l}\text { Berries } \\
\text { cluster-1 }\end{array}$ & $\begin{array}{c}\text { Berry } \\
\text { mass (g) }\end{array}$ \\
\hline \multirow{11}{*}{ Bobal } & \multirow{2}{*}{2014} & NS & 2.9 & 6.3 & 421 & 120 & $3.0 \mathrm{~b}$ \\
\hline & & EW & 2.9 & 6.6 & 422 & 135 & $3.2 \mathrm{a}$ \\
\hline & \multirow{2}{*}{2015} & NS & $10.5 b$ & 13.3 & 785 & $287 b$ & 2.7 \\
\hline & & EW & $11.8 \mathrm{a}$ & 14.4 & 813 & $319 a$ & 2.5 \\
\hline & \multirow{2}{*}{2016} & NS & 5.3 & 8.1 & 613 & 193 & 3.2 \\
\hline & & EW & 4.8 & 8.9 & 540 & 170 & 3.2 \\
\hline & \multirow{5}{*}{ Average } & NS & 6.3 & 9.2 & 608 & 200 & 3.0 \\
\hline & & EW & 6.5 & 10.0 & 592 & 208 & 3.0 \\
\hline & & Treatment & 0.497 & 0.096 & 0.580 & 0.406 & 0.849 \\
\hline & & Season & 0.000 & 0.000 & 0.000 & 0.000 & 0.000 \\
\hline & & $\mathrm{T} \times \mathrm{S}$ & 0.059 & 0.780 & 0.198 & 0.021 & 0.247 \\
\hline \multirow{11}{*}{ Verdejo } & \multirow{2}{*}{2014} & NS & 1.8 & 16.7 & 92 & 32 & $2.8 \mathrm{~b}$ \\
\hline & & EW & 2.0 & 16.2 & 113 & 34 & $3.3 \mathrm{a}$ \\
\hline & \multirow{2}{*}{2015} & NS & 4.4 & 24.9 & 178 & 70 & $2.6 \mathrm{~b}$ \\
\hline & & EW & 4.4 & 24.5 & 179 & 64 & $2.8 \mathrm{a}$ \\
\hline & \multirow{2}{*}{2016} & NS & $4.5 a$ & 24.5 & 173 & 87 & $2.0 \mathrm{~b}$ \\
\hline & & EW & $3.6 \mathrm{~b}$ & 23.6 & 167 & 77 & $2.2 \mathrm{a}$ \\
\hline & \multirow{5}{*}{ Average } & NS & 4.1 & 23.6 & 164 & 73 & $2.4 \mathrm{~b}$ \\
\hline & & EW & 3.7 & 23.0 & 166 & 67 & $2.7 \mathrm{a}$ \\
\hline & & Treatment & 0.411 & 0.630 & 0.486 & 0.150 & 0.000 \\
\hline & & Season & 0.000 & 0.000 & 0.000 & 0.000 & 0.000 \\
\hline & & $\mathrm{T} \times \mathrm{S}$ & 0.058 & 0.950 & 0.408 & 0.314 & 0.053 \\
\hline
\end{tabular}

For each parameter, data are average values of the experimental units $(n=4)$. Within each season and cultivar, different letters mean significant differences at $p<0.05$. The statistical significance effect of the treatment (T), season (S) and their interaction are also indicated. Treatments are: NS, north-south and EW, east-west vineyard row's orientation.

In both cultivars, berry composition at harvest was affected by vineyard trellis orientation direction (Table 10). TSS was inconsistently affected in the first two seasons and unaffected in 2016. For both cultivars in 2014, berries from NS had lower TSS than the ones from EW, but the opposite was found in 2015. The effects of the row orientation on grape TA were not consistent for Bobal; but for Verdejo the NS orientation induced higher TA values than the EW orientation. Similarly, the maturity index was differently affected by row orientation in each cultivar. In Bobal, the NS orientation increased the maturity index in 2015, whereas in Verdejo, the NS decreased it in 2015. Overall, the pH was not affected by the treatments in any cultivar. 
Bobal grapes' phenolic compounds were overall unaffected (Table 10). The only effect of row orientation on phenolic composition at harvest was observed in 2015. In this season, both berry anthocyanin concentration and total polyphenols index were significantly diminished by EW as compared to NS. Notwithstanding, with phenolic data pooled across seasons, the effect of treatment and season was interactive.

Table 10. Seasonal and annual average values of berry composition parameters of Bobal and Verdejo winegrapes subjected to different vineyard row's orientation.

\begin{tabular}{|c|c|c|c|c|c|c|c|c|}
\hline Cultivar & Season & Orientation & $\begin{array}{c}\text { TSS } \\
\left({ }^{\circ} \text { Brix }\right)\end{array}$ & $\begin{array}{c}\text { TA } \\
(\mathrm{g} / \mathrm{L})\end{array}$ & pH & $\begin{array}{c}\text { Maturity index } \\
\left({ }^{\circ} \text { Brix } / \mathrm{g} / \mathrm{L}\right)\end{array}$ & $\begin{array}{l}\text { Anthocyanins } \\
\text { (mg/g) }\end{array}$ & $\begin{array}{r}\text { TPI } \\
(\mathrm{AU})\end{array}$ \\
\hline \multirow{11}{*}{ Bobal } & \multirow{2}{*}{2014} & NS & $15.1 \mathrm{~b}$ & $7.0 \mathrm{~b}$ & $3.2 \mathrm{a}$ & 2.2 & 0.6 & 1.6 \\
\hline & & EW & $15.6 a$ & $7.5 \mathrm{a}$ & $3.1 \mathrm{~b}$ & 2.1 & 0.6 & 1.9 \\
\hline & \multirow{2}{*}{2015} & NS & $15.4 \mathrm{a}$ & 5.4 & 2.8 & $2.8 \mathrm{a}$ & $0.2 \mathrm{a}$ & $1.9 \mathrm{a}$ \\
\hline & & EW & $12.6 \mathrm{~b}$ & 5.9 & 2.8 & $2.1 \mathrm{~b}$ & $0.1 \mathrm{~b}$ & $1.7 \mathrm{~b}$ \\
\hline & \multirow{2}{*}{2016} & NS & 16.9 & 7.7 & 3.1 & 2.2 & 0.4 & 1.8 \\
\hline & & EW & 16.8 & 7.6 & 3.1 & 2.2 & 0.4 & 1.9 \\
\hline & \multirow{5}{*}{ Average } & NS & $15.6 \mathrm{a}$ & 6.3 & 3.0 & $2.6 \mathrm{a}$ & 0.03 & 1.8 \\
\hline & & EW & $14.4 \mathrm{~b}$ & 6.7 & 3.0 & $2.2 \mathrm{~b}$ & 0.03 & 1.8 \\
\hline & & Treatment & 0.000 & 0.081 & 0.610 & 0.000 & 0.07 & 0.557 \\
\hline & & Season & 0.000 & 0.000 & 0.000 & 0.000 & 0.000 & 0.036 \\
\hline & & $\mathrm{T} \times \mathrm{S}$ & 0.000 & 0.191 & 0.640 & 0.000 & 0.003 & 0.001 \\
\hline \multirow{11}{*}{ Verdejo } & \multirow{2}{*}{2014} & NS & $21.6 a$ & $4.6 \mathrm{a}$ & $3.5 b$ & $4.7 \mathrm{~b}$ & - & - \\
\hline & & EW & $22.7 \mathrm{~b}$ & $4.4 \mathrm{~b}$ & $3.6 \mathrm{a}$ & $5.1 \mathrm{a}$ & - & - \\
\hline & \multirow{2}{*}{2015} & NS & $19.8 \mathrm{a}$ & $4.6 a$ & 3.2 & 43 & - & - \\
\hline & & EW & $19.0 \mathrm{~b}$ & $4.4 \mathrm{~b}$ & 3.2 & 4.3 & - & - \\
\hline & \multirow{2}{*}{2016} & NS & 20.6 & 5.5 & $3.3 \mathrm{a}$ & 3.7 & - & - \\
\hline & & EW & 20.6 & 5.6 & $3.2 \mathrm{~b}$ & 3.7 & - & - \\
\hline & \multirow{5}{*}{ Average } & NS & 20.6 & $4.9 \mathrm{a}$ & 3.3 & $4.2 \mathrm{~b}$ & - & - \\
\hline & & EW & 20.5 & $4.8 \mathrm{~b}$ & 3.3 & $4.3 \mathrm{a}$ & - & - \\
\hline & & Treatment & 0.539 & 0.029 & 0.383 & 0.029 & - & - \\
\hline & & Season & 0.000 & 0.000 & 0.000 & 0.000 & - & - \\
\hline & & $\mathrm{T} \times \mathrm{S}$ & 0.000 & 0.067 & 0.000 & 0.003 & - & - \\
\hline
\end{tabular}

For each parameter, data are average values of the experimental units. Within each season and cultivar, different letters mean significant differences at $p<0.05$. The statistical significance effect of the treatment (T), season (S) and their interaction are also indicated. TA, titratable acidity; TPI, total polyphenols index. Treatments are: NS, north-south and EW, east-west vineyard row's orientation. 


\section{Discussion}

Vine phenology was advanced in both cultivars compared to the traditional dates at their common sites of cultivation (Salón et al. 2005, Vilanova et al. 2014). This could be attributable to the warm conditions at our experimental site (Figure 20). Regardless of this, in the Bobal variety, the NS vineyard row's orientation significantly advanced phenology in comparison to the EW orientation (Figure 21). This can be explained by the influence of radiation interception in the canopy's thermal distribution. The fact that phenology and shoot growth advancements were only reported in Bobal (Figure 22), suggests that the thermal variation effects on vine phenology may differ among cultivars. Moreover, phenology advance could have been influenced by the fact that the experiment was performed with potted vines and the heating effects on the root system might have exacerbated the physiological differences. Therefore, the shifts in Bobal phenology found here might not be able to be fully extrapolated to field conditions. In addition, the advancement of the phenology stages was attenuated during the course of the season due to the continuous increase in the accumulation of growing degree days per unit of time.

The significant vine water-use reductions observed in the EW orientation compared to the NS during the three seasons (Table 7) are consistent with the simulations of PAR absorption by different rows orientation performed by Campos et al. (2017). Therefore, regardless the complex regulation of canopy transpiration, the absence of water stress means that the lower the daily irradiance to the canopy, the lower the vine transpiration. This finding was somehow confirmed by the slightly better vine water status $\left(\Psi_{\text {stem }}\right)$ of the EW compared to NS (Figure 23). Although, in agreement to what Hunter et al. (2016) reported for Shiraz grapevines, the differences among orientations on vine water potential were minor. In the present experiment, differences in water status among rows orientations were only found in $\Psi_{\text {stem. }}$. At pre-dawn, when canopies were not transpiring, EW and NS vines had a similar water status because irrigation was applied in both cultivars to fulfil water requirements. At midday, water status was controlled by substrate water content and by canopy transpiration, which increased in NS vines, resulting in a lower $\Psi_{\text {stem. }}$ In general, the transpiration rates measured at leaf level showed similar patterns to the whole-vine transpiration determinations. Similarly, Medrano et al. (2012) found a good relationship between leaf gas exchange and daily intercepted light (PAR) in well-irrigated vines. Nevertheless, in our trial, the overall transpiration reductions induced by EW in comparison to NS determined by the water balance methodology were 13\% in Bobal and 7\% in Verdejo, whereas using the leaf gas exchange analyser, the differences were only $7 \%$ and $4 \%$, 
respectively (Table 8). Poni et al. (2009) suggested caution in extrapolating single-leafbased determinations to the whole-canopy level. Certainly, the elevated variability of leaf transpiration values could have partially masked the row orientation effects. This might be because we measured leaf gas exchange only in sunny basal-leaves, which are older and less active than younger ones (Kliewer and Antcliff 1970). In any case, leaf gas exchange average values were overall within the expected range for basal leaves of non-stressed vines (Escalona et al. 2003). Bobal did not experience any stomatal conductance $\left(\mathrm{g}_{\mathrm{s}}\right)$ reduction at midday in comparison to the morning, but at midday photosynthesis (A) was already reduced by $11 \%$ on average in Bobal, and by $13 \%$ in Verdejo (Table 8 ). This is an expected trend due to photo-inhibition processes under midday conditions and warm temperatures (Gamon and Pearcy 1990, Vicente 2017). Later in the afternoon, there was a more pronounced decrease in leaf gas exchange rate, likely as a consequence of higher ambient temperatures and VPD along the day (Cuevas et al. 2006). These differences were much more marked in the EW orientation than in the NS, which is what presumably induced greater water-use differences during the afternoon (Figure 25). In any case, the Verdejo responses to the modification of solar interception pattern were less pronounced than in Bobal (Figure 24). This was not expected, as Verdejo is supposedly better adapted to humid conditions than Bobal, and therefore should have a lower stomatal regulation capacity. However, it has been shown that some white cultivars can limit their physiological activity when leaf temperature exceeds $30 \stackrel{\circ}{\circ}$ (Zufferey et al. 2000). This could have occurred in Verdejo during the peak of the day between June and August (Figure 20). Interestingly, the increments found in both cultivars in the $\mathrm{g}_{\mathrm{s}}$ of NS compared to EW were higher than the increments induced in net photosynthesis rates (A). This behaviour could be pointing to shifts in WUE induced by row orientation at a physiological basis. Moreover, contrary to what Intrieri et al. (1998) reported in potted Chardonnay, we did not observe any differences in carbon assimilation or water transpiration between NS and EW during the midday hours that could have induced higher WUE in NS rows than in EW.

The higher WUE in the EW in comparison to NS, calculated as the ratio between yield and water-use, was consistent in both cultivars (Table 7). It should be noted that for wateruse and WUE, the significant effect of the season and its interaction with the treatments was simply explainable by the different periods of water-use measurement (Figure 24). Overall, the higher water-use of NS-oriented vines compared to EW, or the higher photosynthesis rates measured at leaf level, did not result in higher yields. The results obtained under potted conditions may be extrapolated to field conditions because 1) according to Hunter et al. (2017), shifts in bud fertility, berry set and general morphology of clusters due to row 
orientation effects are not expected, and 2) the radiation balance would be comparable to a greater extent. However, it is true that in our conditions, soil evaporation was not a component of the vineyard's water balance. Under field conditions, it is possible that some of the radiation load which is not intercepted by the canopy, could increase soil evaporation. In addition, the transpiration response to the light interception pattern could be different under vine water stress conditions (Williams 2012). For instance, in a seven-year trial in field-grown Shiraz under mild water stress, the NS row orientation consistently yielded more than EW (Hunter et al. 2016, 2017). Notwithstanding, the differences in yield were only detectable statistically by means of a genotype plus genotype $\mathrm{x}$ environment interaction Biplot analysis (Yan et al. 2007). Moreover, Hunter et al. (2017) found minor differences in vegetative characteristics. In our trial, Verdejo produced similar total dry matter in both orientations, but in Bobal, the NS orientation increased the vine dry matter production (Table 7). Certainly, the NS orientation increased shoot growth rate in Bobal since the very beginning (Figure 22). In Bobal, indeed, if shoot trimming had not been performed, differences in water-use between NS and EW would have been even higher. In Verdejo, LA was increased on a seasonal average basis in EW compared to NS, but this was mainly attributable to the 2015 differences. Interestingly, in both cultivars, vine water-use related to its corresponding LA was significantly reduced in the EW by $18 \%$ on seasonal average in comparison to NS (Table 7). This highlights the importance of the radiation load intercepted by the canopy in water-use and water productivity. It has been found that the response to water-use depends on the genotype (Figure 26). This highlights the importance of the intrinsic architecture of the cultivars, or as Louarn et al. (2008) expressed, the genotypic differences in the ability to capture light. Our findings suggest the need for further winegrapes studies on sunlight interception and canopy architectures at the physiological basis, as possible techniques for adapting vineyards to climate change under Mediterranean climates.

The relevance of the study was the assessment of vineyard water-use in response to row direction modification in vertical homogeneous hedgerow canopies under no water restrictions (Figure 24). On the other hand, it is interesting to note that yield components were unaffected by the reductions in the radiation load provoked by orienting vineyard trellis systems EW instead of NS (Table 9); and therefore, as water-use can be reduced by the EW row orientation, WUE may be increased (Table 7). The only yield component that was significantly affected by the vineyard row's orientation was berry mass, which in the Verdejo trial increased in the EW treatment (Table 9). According to Hunter et al. (2016) this might be because of a lower berry transpiration in the cluster of the EW-oriented vines. In 
addition, it could also be that the better midday water status of the Verdejo vines when oriented EW stimulated berry growth, as it is very dependent on turgor pressure and hence on vine water status. Berry size is of major importance to oenology, since most of the aromas and phenolic components are in found in the berry's skin (Ojeda et al. 2002).

In the two cultivars under study, berry composition at harvest was not consistently affected by the trellis system orientation (Table 10). This is agreement with Intrieri et al. (1996) for Chardonnay, or with Naylor et al. (2000) for Sauvignon blanc. In Verdejo, the higher grape TA for the EW orientation with respect to the NS was in agreement with the findings by Giacosa et al. (2015). In Bobal, despite the slight differences observed in the onset of berry ripening (Figure 21), the differences found in TSS were more explainable by the changes in the LA-to-yield ratio rather than by row orientation. This is due to the LA-toyield ratio's important influence on grape-ripening rates (Poni et al. 2017). It should be noted that for Bobal in 2015 and for Verdejo in 2016, according to Kliewer and Dokoozlian (2005), the values of LA-to-yield ratio suggested that vines were over-cropped and were thus incapable of achieving complete ripening (Table 7). This was confirmed in Bobal EW, in which in 2015 TSS was significantly reduced in EW compared to NS (Table 10). Furthermore, this was the only season in which the phenolic maturity was significantly affected by row orientation. Overall, phenolic composition at harvest showed no significant differences between row orientations. This was in accordance with the one-season study in Shiraz grapes that showed no differences in anthocyanin content between our same two vineyard row orientations under field conditions (Giacosa et al. 2015). There are many experiments that have assessed vineyard trellis type on berry composition (Reynolds and Vanden Heuvel 2009), but we identified a lack of knowledge on the trellis system orientation effects on the complex grape-ripening processes. This should be better addressed under field conditions with a larger number of experimental vines.

\section{Conclusions}

These experiments provide novel insights on the effects of the vineyards row's orientation on water-use depending on the grapevine genotype. Vine transpiration was reduced in the EW row orientation in comparison to NS by $13 \%$ in Bobal and by $7 \%$ in Verdejo, corresponding to an $18 \%$ reduction relative to total leaf area in both cultivars. Consequently, WUE was significantly increased in EW compared to NS by $26 \%$ in Bobal and $19 \%$ in Verdejo. Therefore, at Mediterranean latitudes, where solar radiation falls more 
perpendicular to the Earth's surface during summer, modifying canopy sunlight interception by orienting vineyard rows EW instead of NS, reduces water-use and increases water-productivity. These responses indicate that, in warm and semiarid climates and especially within the context of climate change, minimizing daily vineyard radiation load by modifying row orientation should be recommended. Nevertheless, more effort is needed to corroborate these findings in field conditions under different degrees of water stress, paying close attention to the potential effects on grape composition. A better understanding of cluster light exposure effects on berry-ripening due to vineyard row's orientation is needed. 


\section{Chapter IV}

\section{DELAYING BERRY RIPENING BY LATE}

LEAF REMOVAL FOR AMELIORATING

GRAPE AND WINE COMPOSITION OF CVS.

BOBAL AND TEMPRANILLO

This chapter is an adaptation of a manuscript submitted to the Australian Journal of Grape and Wine Research which was declared acceptable after major revisions on $1^{\text {th }}$ of April 2018.

Buesa, I., Caccavello, G., Basile, B., Merli, M. C., Poni, S., Chirivella, C. and Intrigliolo, D. S. Delaying berry-ripening of Bobal and Tempranillo grapevines by late leaf removal in a semi-arid and temperate-warm climate under different water regimes 


\section{DELAYING BERRY-RIPENING OF BOBAL AND TEMPRANILLO GRAPEVINES BY LATE LEAF REMOVAL}

\section{Introduction}

Climate is a major component of wine grape terroirs (Castel et al. 2012, Hannah et al. 2013). Mediterranean viticulture could suffer from warmer and drier growing seasons over the coming decades (Lereboullet et al. 2013a). Indeed, wine grapes are considered to be more vulnerable to climate change compared to other crops, because most of the added value of the final product is provided by the desired wine style that depends on grape composition at harvest (Jones and Webb 2010).

Warmer conditions induce increases in sugar accumulation rate in the berries (Petrie and Sadras 2008), leading to higher alcohol concentrations in wine or earlier harvest dates (Jones et al. 2005a, Koufos et al. 2014, Cook and Wolkovich 2016). Others authors have also documented the shortening of vine phenological cycle in response to an increase in ambient temperature (Duchêne and Schneider 2005). In addition, Sadras and Moran (2012) observed that high temperature decouples the synthesis of sugars and anthocyanins of Shiraz and Cabernet Franc grown in South Australia. In this regard, the higher probability of heat waves and droughts events (IPCC 2014) will increase the frequency and severity of plant water stress (Gambetta 2016). Irrigation management (Salón et al. 2005, Castel et al. 2012), canopy trellising systems (Baeza et al. 2005, Kliewer and Dokoozlian 2005), artificial shading (Kliewer et al. 1967, Caravia et al. 2016) and/or source-to-sink ratio reductions (Stoll et al. 2010, Palliotti et al. 2013a) may delay ripening so that it occurs during cooler periods of the season. Practices such as pruning, trimming and leaf removal can be certainly employed to manipulate vine source-sink balance (Caccavello et al. 2017, Moran et al. 2017, Santesteban et al. 2017).

Late Leaf removal (LLR), defined as leaf removal applied late in the season (near veraison) tends to have a limited effect on fruit yield but it can postpone grape ripening (Palliotti et al. 2013a, Caccavello et al. 2017). For instance, Intrieri et al. (2017), after removing 30-40\% of total vine leaf area, achieved an increase in anthocyanin concentration in Sangiovese berries when the harvest date was delayed 7-8 days. Poni et al. (2013), after applying LLR at veraison in the same cultivar, delayed the technologically-defined ripeness without affecting berry colour or the concentration of phenolics. Lanari et al. (2013) found 
that LLR negatively-affected anthocyanin and polyphenol concentration in Montepulciano grapevines, but not in Sangiovese ones. Bobeica et al. (2015) reported, in potted Sangiovese and Cabernet Sauvignon vines, that sugar accumulation in berries could be maintained at the expense of phenolic components under leaf area removal. Moreover, the carbon limitation affected anthocyanin profiles in a cultivar-dependent manner. Therefore, it appears that the response to LLR may vary depending on the cultivar genotype.

In semi-arid climates, the effect of LLR can be different depending on the irrigation regime, because of the significant effects of watering applications on vine vigour and berry growth and development (Jackson and Lombard 1993, Risco et al. 2014). Moreover, irrigation management could also partially restore the disruption caused by high temperature on the anthocyanins-to-sugars ratio if a water deficit is applied shortly before veraison (Sadras and Moran 2012). Pre-veraison water stress may lead to an increased must concentration of total phenolics and anthocyanins because it can stimulate anthocyanin biosynthesis in berry skin (Castellarin et al. 2007a, Santesteban et al. 2011a) and it can induce an increase in the skin-to-pulp ratio (Ojeda et al. 2002, Intrigliolo and Castel 2010). Similarly, post-veraison water stress can promote higher concentrations of phenolics in berry skins and in addition, it may cause a decrease in berry sugar accumulation in the Tempranillo variety (Esteban et al. 2001, Intrigliolo et al. 2012). Nevertheless, severe postveraison water stress may be detrimental to anthocyanin accumulation (Girona et al. 2009, Romero et al. 2010b). Salón et al. (2005) and Intrigliolo and Castel (2011) reported that maintaining midday stem water potentials $\left(\Psi_{\text {stem }}\right)$ above specific thresholds during postveraison (-1.2 and -1.5 MPa MPa in Bobal and Tempranillo, respectively) induced an increase in total anthocyanin concentration and colour intensity in the must and wine.

In this trial we assessed the effects of late leaf removal (LLR) on the ripening dynamics and yield components of Bobal and Tempranillo red cultivars in a semiarid and temperatewarm climate under different watering regimes (WR). To the best of our knowledge, all previous studies have in fact determined the effects of LLR within a given watering regime, and under cooler and more humid areas (Lanari et al. 2013, Palliotti et al. 2013a, Poni et al. 2013, Caccavello et al. 2017, Intrieri et al. 2017). Our working hypothesis was that the LLR technique could delay fruit ripening, thereby alleviating grape heat stress, while irrigation effects could interact differently depending on the cultivar. In this context, we were interested on the photosynthetic compensatory response to LLR under different WR. Particularly, we investigated if LLR applied under both deficit irrigation and rainfed conditions could improve grape and wine phenolic content. 


\section{Materials and methods}

Site and crop

The trials were carried out in 2014 and 2015 in a commercial grapevine (Vitis vinifera

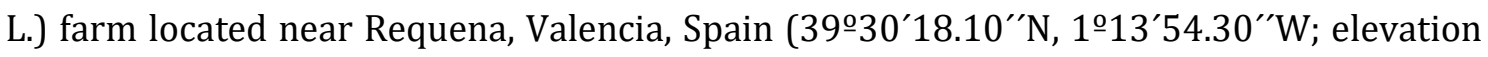
$700 \mathrm{~m}$ a.s.l.). The experiments were conducted in two adjacent vineyards planted, respectively, with cv. Bobal (grafted onto 110 Richter) and cv. Tempranillo (grafted onto 161-49 Couderc) vines. Vines were trained to a bilateral cordon system leaving six or ten two-bud spurs per vine in the Bobal and Tempranillo vineyard, respectively (Figure 27). Shoots were trained vertically using a pair of steel catch wires. The Bobal vineyard was planted in 2002 at a spacing of $2.5 \times 1.4 \mathrm{~m}$ (2857 vines ha-1), whereas the Tempranillo vineyard was planted in 1991 at $2.5 \mathrm{~m}$ x $2.45 \mathrm{~m}$ (1633 vines ha-1). In both vineyards, rows were oriented North-South. The two plots were independently deficit irrigated with two drippers per plant for more than ten years before the present experiments were started.

The vineyard's soil was a Typic Calciorthid with a clay-loam to light clay texture, highly calcareous and with low fertility. Soil depth was higher than $2 \mathrm{~m}$ and available water capacity was about $200 \mathrm{~mm} \mathrm{~m}^{-1}$. The climate in this area was continental Mediterranean and semiarid, the heliothermal index of Huglin (Huglin 1978) was $2291^{\circ} \mathrm{C}$ corresponding to a temperate-warm viticultural climate, with cool nights and moderately dry according to the classification system for grape-growing regions proposed by Tonietto and Carbonneau (2004). At the experimental site, the annual average values (for the 2002-2013 period) of the reference evapotranspiration (ETo) and the rainfall were 1127 and $380 \mathrm{~mm}$ respectively. About $65 \%$ of the precipitation generally occurs in winter.

\section{Sources of variation}

Four treatments were tested in each trial, obtained by combining two types of watering regimes (WR, Irrigated or Rainfed) and two types of canopy managements (CM, Defoliated or Undefoliated). The treatments applied were: Irrigated-Undefoliated, IU; Irrigated-Defoliated, ID; Rainfed-Undefoliated, RU; Rainfed-Defoliated, RD (Table 11). The treatments had three and four replicates in the Bobal and Tempranillo trial, respectively. In both cases, the experimental design was a randomized block design, where WR was assigned to the main plot and $\mathrm{CM}$ to subplots. The vines located in the surrounding 
perimeter of the plots were used as borders. Each subplot or experimental unit (EU) consisted of a row of ten and seven vines in the Bobal and Tempranillo trial, respectively.

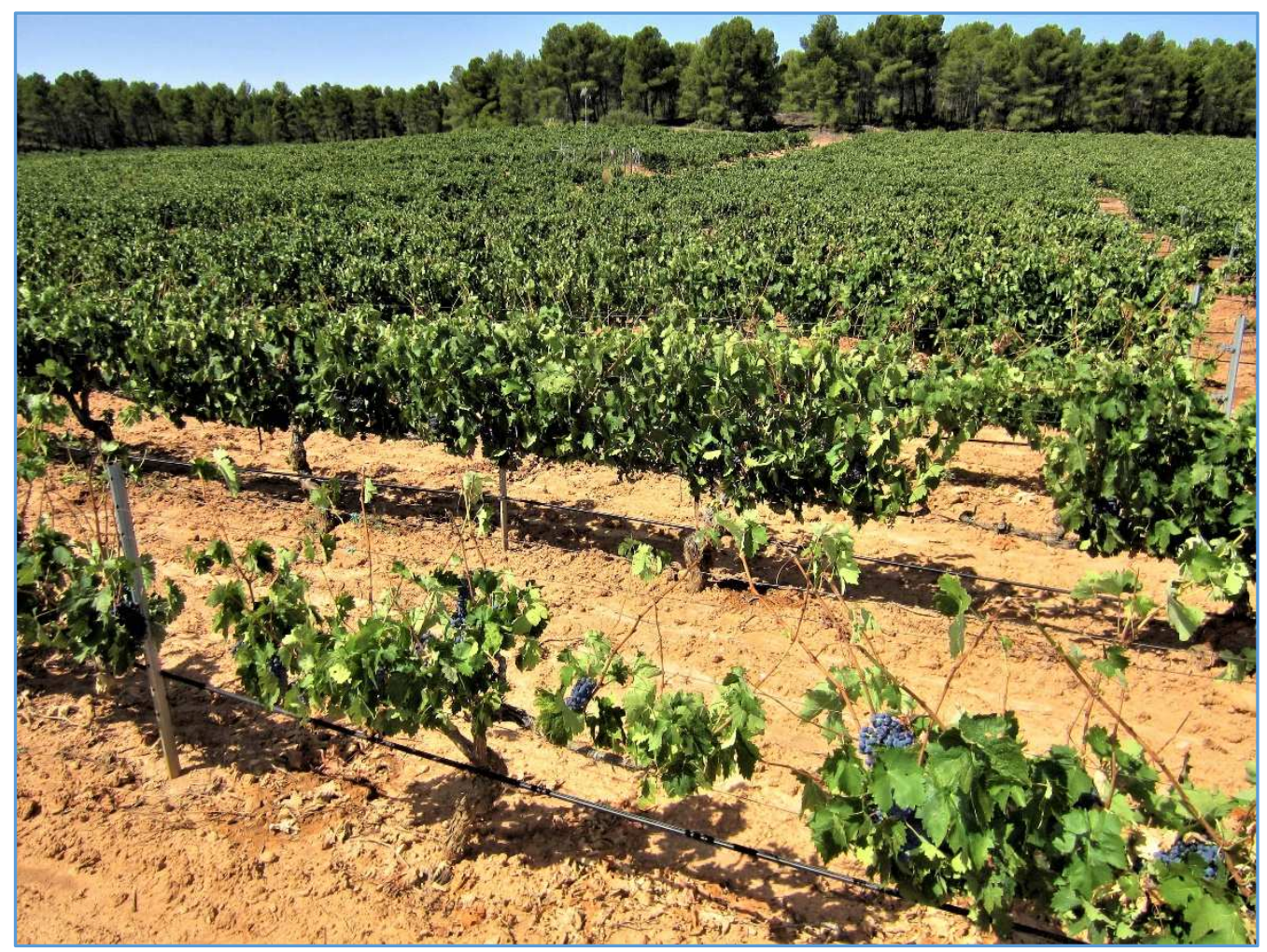

Figure 27. Overview of the Tempranillo vineyard; first row: Irrigated-Defoliated vines; second row, Irrigated-Undefoliated vines.

Deficit irrigation was applied to maintain midday $\Psi_{\text {stem }}$ above the threshold values of -1.15 and $-1.40 \mathrm{MPa}$ in pre- and post-veraison, respectively. Late leaf removal was performed manually at the onset of berry ripening (Phase III of berry development), corresponding to phenological stage number 79-81 in the BBCH-scale (Lorenz et al. 1995). The goal was to reduce the vine's photosynthetic capacity at the beginning of the berryripening process. Defoliation consisted of removing all the mature apical leaves of the main shoots and removing lateral shoots starting from the second node above the clusters (only the leaves at the top of the shoot were retained; Figure 28). This was done because at around veraison, the leaves located in the apical two-thirds of the shoots are considered to be the most photosynthetically active (Poni et al. 1994). Shoot tips were preserved in order to allow for potential lateral shoot regrowth to compete for photoassimilates with grapes (McCarthy 1997). Cluster zones were left unchanged by the defoliation. 


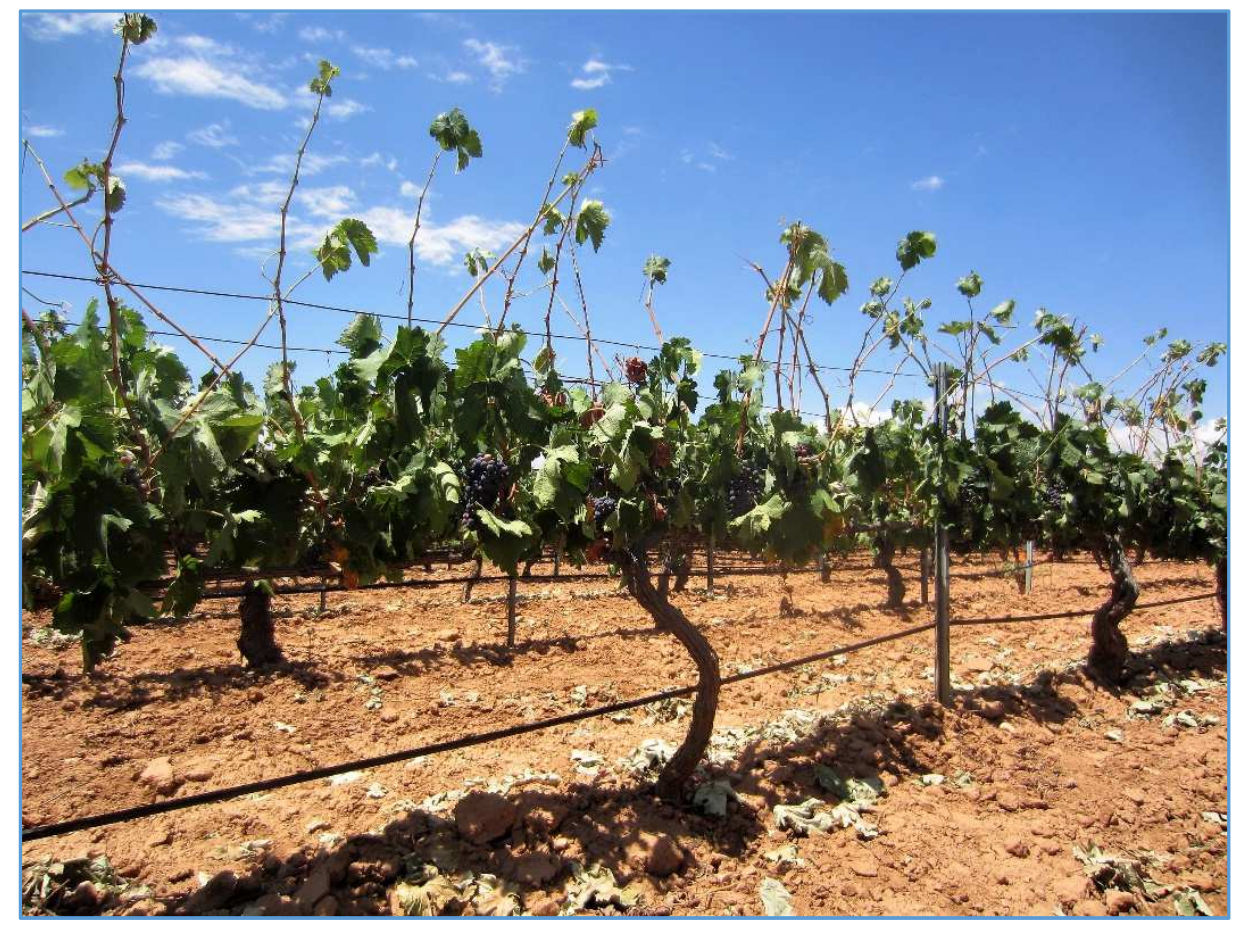

Figure 28. Appearance of Boba Irrigated-Defoliated vines at full-veraison in 2014.

\section{Field determinations}

During the experiment, weather data were hourly measured with an automated meteorological station located at the vineyard. Reference evapotranspiration $\left(\mathrm{ET}_{\mathrm{o}}\right)$ was calculated with the Penman-Monteith equation (Allen et al. 1998). Cumulative growing degree days (GDD) from April $1^{\text {st }}$ until harvest was computed as the sum of the average daily temperature above a threshold $10{ }^{\circ} \mathrm{C}$ (Amerine and Winkler 1944). The amount of water applied with irrigation was measured with on-line water meters. Midday $\Psi_{\text {stem }}$ was measured, respectively, on six and four dates in 2014 and 2015 with a pressure chamber (Model 600, PMS Instrument Company, USA) on bag-covered leaves from two representative vines per EU at midday (measurements were carried out between 11:30 and 12:30 solar time). Leaves used for these measurements were located on the west side of the row and were enclosed in hermetic plastic bags covered with aluminium foil for at least 1 hour prior to the measurements. In addition, on the last three dates, net $\mathrm{CO}_{2}$ assimilation rate, transpiration rate and stomatal conductance were measured (between 10:00 and 13:00 solar time) on two basal, mature, sun-exposed leaves per vine with a portable gas exchange analyser (LCpro+, ADC BioScientific Ltd., England).

Fruit yield, number of clusters per vine, average cluster weight and shoot fruitfulness (number of clusters per shoot) were determined at harvest on each experimental vine. 
Additionally, one cluster per vine was randomly sampled at harvest in order to determine the number of berries per cluster. In 2016, when the treatments were not applied, vines were assessed to evaluate possible carry-over effects of the two consecutive experimental seasons on vine performance and shoot fruitfulness. Pruning fresh mass was weighted from samples from four vines per EU in Bobal and three in Tempranillo (in 2015 in the latter vineyard this measurement was not done because a mechanical pre-pruning was carried out by the vineyard's owner).

External leaf area (LAext) per vine was determined by photographic analysis by means of an image processing software (Image $1.47 \mathrm{v}$, National Institutes of Health, USA) following the methodology described by (Schneider et al. 2012). The pictures were taken once the shoot growth had ceased, just after the late leaf removal, on one side of the canopy hedge with a background curtain using a visible light camera (Ixus 220 HS, Canon Inc., Tokyo, Japan). Additionally, on one representative vine per EU and cultivar, total leaf area ( LA $_{\text {measured }}$ ) was estimated using allometric relationships computed for each cultivar between shoot length and leaf area per shoot measured with a LI-3100 Area Meter (LI-COR Inc. Lincoln, Nebraska, USA). These relationships were obtained by separating main and lateral shoots, using samples of 12 shoots of different vigour. The significant $L A_{\text {ext }}$ and $L A_{\text {measured }}$ regression equations were used to estimate leaf area (LA) in each experimental vine. Leaf area index (LAI) was calculated as the LA per unit ground surface area. The leaf area removed of the selected vines was measured with a LI-3100 Area Meter.

\section{Grape and wine composition}

Berry ripening evolution was assessed approximately every 10 days, starting from the day before LLR was performed until harvest, except for phenolic composition, which was determined only after veraison. Berry fresh mass was determined from random samples of 50 berries per EU. Thirty berries were crushed and hand pressed through a metal screen filter and used to evaluate technologically-defined maturity, whereas 20 berries were homogenised with a blender (Ultraturrax T25, IKA-Werke GmbH \& Co. KG, Staufen, Germany) and used for phenolic maturity. Must total soluble solids (TSS) were determined by refractometry (PR-101, Series Palette, Atago Co, LTD, Japan), pH and titratable acidity (TA) were measured with an automatic titrator (Metrohm, Herisau, Switzerland). Juice was titrated with a $0.1 \mathrm{~N}$ solution of $\mathrm{NaOH}$ to an end point of $\mathrm{pH} 8.2$, and results were expressed in tartaric acid equivalents. In order to assess the effects of the treatments on berry ripening, the soluble solids-to-titratable acidity ratio (TSS-to-TA) was used as a maturity index, by 
dividing total sugars content ( ${ }^{\circ}$ Brix) by the TA ( $\mathrm{g} \mathrm{L}^{-1}$ ) at harvest (Kliewer and Weaver 1971). Tartaric and malic acid concentrations were measured only at harvest with an infrared analyser (Bacchus II, Tecnología Difusión Ibérica S.L.). Total anthocyanins and polyphenols (expressed in malvidin equivalents) were determined in duplicate by ultraviolet/visible light spectrophotometry (Iland et al. 2004).

The harvest was carried out when each treatment reached specific target TSS levels that were defined for each cultivar and season, and therefore, it was performed at different dates depending on the treatment. In the first season, the TSS target corresponded to full berry maturity for both cultivars (25 ${ }^{\circ}$ Brix), whereas in 2015 , with the aim of increasing comparability among treatments, the TSS goal was set at 22 and $20{ }^{\circ}$ Brix for Tempranillo and Bobal, respectively. The grapes of each EU were separately vinified at the experimental winery. Thus, in each season, 12 and 16 vinifications were performed for Bobal and Tempranillo, respectively. Grapes were mechanically crushed, destemmed and fermented at a temperature of approximately $22^{\circ} \mathrm{C}$ in $60 \mathrm{~L}$ stainless steel containers. Five grams of $\mathrm{SO}_{2}$ were added to all the musts, and these were then inoculated with $20 \mathrm{~g}$ of commercial Saccharomyces cerevisiae yeast per $100 \mathrm{~kg}$ of grapes (FR Excellence, Lamothe-Abiet). Skin contact time was seven days and during this period they were punched down daily. After alcoholic fermentation was ended, the wines were pressed and decanted into $30 \mathrm{~L}$ demijohns. All the wines were stored for six months before analytical determinations. Wine composition analyses were carried out once the spontaneous malolactic fermentation ended. Phenolic composition was determined by measuring the optical density (OD; nm) using spectrophotometric methods (Ati-Unicam UV-4) as described by Ribereau-Gayon et al. (2000); anthocyanins in $\mathrm{HCl}$ media $\left(\mathrm{OD}_{520}-\mathrm{OD}_{860}\right)$, total polyphenols index (TPI) $\left(\mathrm{OD}_{280^{-}}\right.$ $\left.\mathrm{OD}_{860}\right)$, wine colour intensity $\left(\mathrm{OD}_{420}+\mathrm{OD}_{520}+\mathrm{OD}_{620}-\mathrm{OD}_{860}\right)$ and hue $\left(\mathrm{OD}_{420} / \mathrm{OD}_{520}\right)$. All analytical determinations in grape, must and wine were done in duplicate.

\section{Data analysis}

Data from the two trials (Bobal and Tempranillo) were analysed separately because vines had different ages, rootstocks and vine spacing. For each cultivar, a two-way analysis of variance (ANOVA) was used to test the effect of $\mathrm{WR}, \mathrm{CM}$ and $\mathrm{WR} \times \mathrm{CM}$ interaction on vine traits and grape composition. In case the ANOVA detected significant effects $(\mathrm{P}<0.05)$, mean separation was assessed either with the Duncan's multiple range test (when data followed a normal distribution) or the Kruskal-Wallis procedure from the "Statgraphics Centurion XVI" package (version 16.0.07). For wine composition analysis, a two-way ANOVA was 
performed using the alcohol content as a covariate, because significant linear relationships between alcohol content and colour intensity, anthocyanins and TPI were found.

\section{Results}

Climatic conditions and irrigation applications

During the experimental seasons, from April $1^{\text {st }}$ to September $30^{\text {th }}, \mathrm{ET}_{\mathrm{o}}$ was 946 and $920 \mathrm{~mm}$, the Winkler index was 1892 and 1939, and the rainfall was 96 and $203 \mathrm{~mm}$ in 2014 and 2015, respectively (Figure 29). In 2015, rainfall during the spring was noticeably higher compared to the first season, and this retarded the start of irrigation in 2015. Over the two seasons, the average fraction of $\mathrm{ET}_{\mathrm{o}}$ received by rainfall and irrigation in Bobal and Tempranillo vineyards was $34 \%$ and $28 \%$, respectively (Table 11 ).

During the berry-ripening period, the average maximum air temperatures during July and August were $33.5^{\circ} \mathrm{C}$ in 2014 and $35^{\circ} \mathrm{C}$ in 2015. Moreover, during September, when the grape of the retarded treatments was still ripening, the average was $30.0{ }^{\circ} \mathrm{C}$ and $26.7{ }^{\circ} \mathrm{C}$, respectively. In the Tempranillo trial, the maximum air temperature during the week prior to harvest for the treatments harvested later was $3{ }^{\circ} \mathrm{C}$ lower than in the treatment picked earlier (IU). In the Bobal trial, this difference was up to $7 \stackrel{\circ}{\circ}$. On the other hand, the average minimum air temperatures during the week before harvest was below $18{ }^{\circ} \mathrm{C}$ for all treatments and seasons. 


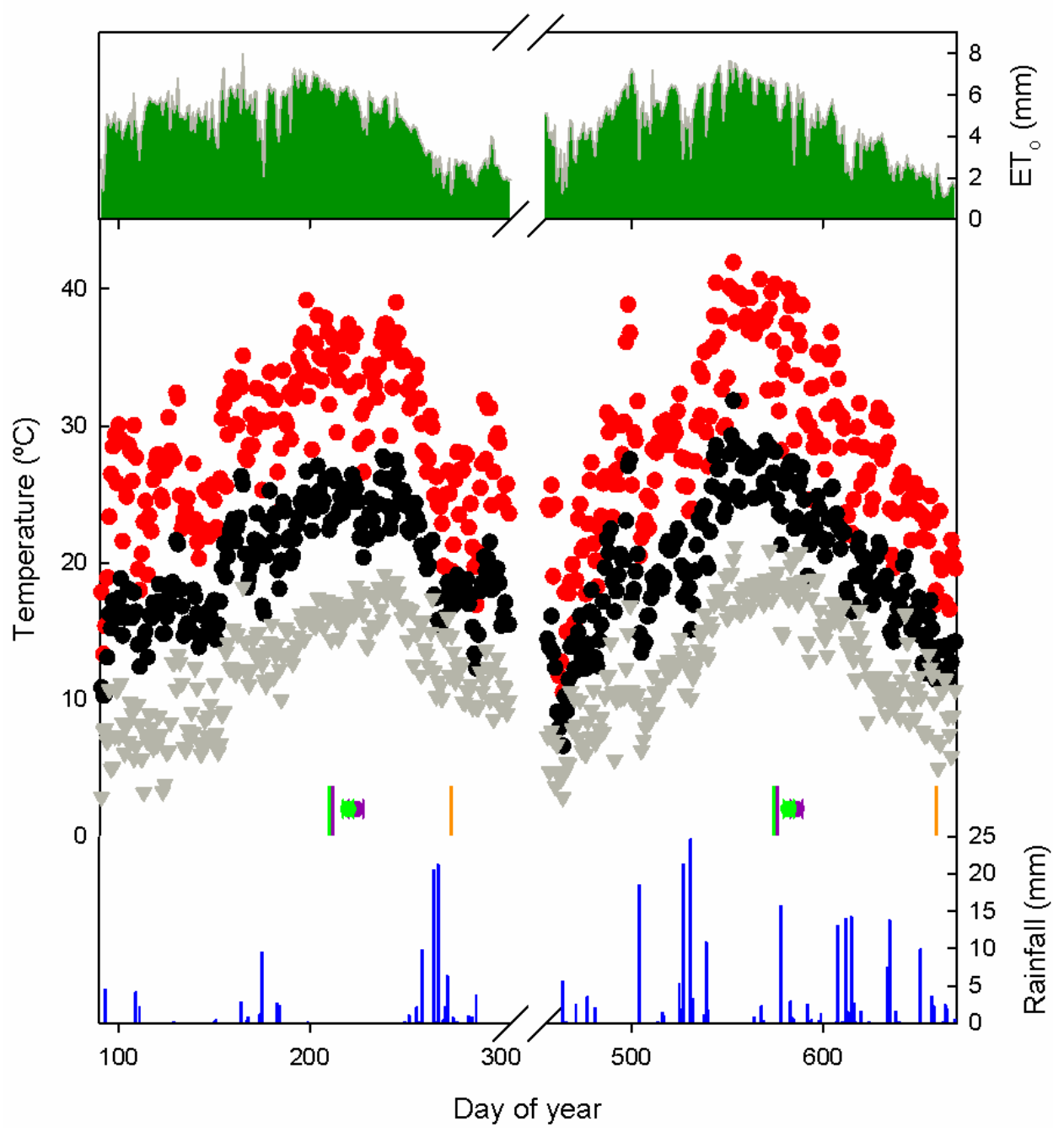

Figure 29. Seasonal patterns of the daily maximum air temperature (O), mean air temperature ( $)$ and minimum air temperature $(\nabla)$ in Requena, Valencia, Spain. The day of year (DOY) follows a continuous time scale starting on 01/01/2014. Rainfall is represented with blue bars and reference evapotranspiration $\left(\mathrm{ET}_{0}\right)$ with green bars. The moment of occurrence of late leaf removal in Bobal ( $\star$ ) and in Tempranillo ( $\star$ ) and the latest harvest for Bobal (\$) and for Tempranillo ( + ) are indicated for each season.

\section{Vine phenology and vegetative growth}

Vine phenology until veraison was similar among treatments within each trial. Indeed, no differences among treatments in the date of budburst, bloom or veraison were found for both cultivars. In both trials, the number of shoots per vine did not differ among treatments, because the seasonal pruning strategy (dormant pruning and early shoot thinning) employed was the same $(19 \pm 2$ and $10 \pm 2$ shoots per vine in Tempranillo and Bobal, respectively). LLR was performed in Bobal on the day of year (DOY) 212 and 211 in 2014 and 2015, respectively; and on DOY 210 and 209 in Tempranillo in 2014 and 2015, 
respectively. This corresponded to 10-12 days before 50\% veraison (BBCH 83), when the berry TSS values were around $9{ }^{\circ}$ Brix.

Table 11. Total amount of water received (rain plus irrigation) from April $1^{\text {st }}$ to September $30^{\text {th }}$ and total leaf area after LLR application in Bobal and Tempranillo vines exposed to the following four treatments: IU, irrigated-undefoliated; ID, irrigated-defoliated; RU, rainfedundefoliated; RD, rainfed-defoliated.

\begin{tabular}{|c|c|c|c|c|c|}
\hline \multirow{2}{*}{ Cultivar } & \multirow{2}{*}{ Treatment } & \multicolumn{2}{|c|}{$\begin{array}{c}\text { Water received } \\
(\mathrm{mm})\end{array}$} & \multicolumn{2}{|c|}{$\begin{array}{c}\text { Total leaf area } \\
\left(\mathrm{m}^{2} \text { vine }^{-1}\right)\end{array}$} \\
\hline & & 2014 & 2015 & 2014 & 2015 \\
\hline \multirow{4}{*}{ Bobal } & $\mathrm{IU}$ & 329 & 311 & $2.9 \mathrm{a}$ & $5.7 \mathrm{a}$ \\
\hline & ID & 329 & 311 & $2.3 \mathrm{~b}[24]$ & $3.9 \mathrm{~b}[32]$ \\
\hline & RU & 96 & 203 & $2.1 \mathrm{~b}$ & $5.6 \mathrm{a}$ \\
\hline & $\mathrm{RD}$ & 96 & 203 & $1.7 \mathrm{c}[23]$ & $3.7 \mathrm{~b}[34]$ \\
\hline \multirow{4}{*}{ Tempranillo } & $\mathrm{IU}$ & 232 & 287 & $5.5 a$ & $4.4 \mathrm{a}$ \\
\hline & ID & 232 & 287 & $4.4 \mathrm{~b}[21]$ & $3.4 \mathrm{~b}[24]$ \\
\hline & RU & 96 & 203 & $4.1 \mathrm{c}$ & $4.3 \mathrm{a}$ \\
\hline & $\mathrm{RD}$ & 96 & 203 & $3.0 \mathrm{~d}[28]$ & $3.1 \mathrm{~b}[30]$ \\
\hline
\end{tabular}

Within each row, mean values followed by a different letter are significantly different at $\mathrm{P}<0.05$. Values between brackets is indicated the percentage of leaf area reduction within watering regime and season.

Pooling the data across seasons, the average LA removed per vine represented $28 \%$ and $25 \%$ of the total vine LA at that moment in Bobal and in Tempranillo, respectively (Table 11). After LLR was applied, vegetative growth was very negligible, probably because the shoot tips' growth (both on the main and lateral shoots) was limited by the moderate water stress experienced by the vines. Lateral shoot regrowth was neither observed in the defoliated vines (LLR treatments) even under irrigation because this regrowth is very dependent upon weather conditions (Poni et al. 2014b). In both cultivars, LAI after leaf removal was significantly lower in the defoliated vines compared to that of undefoliated vines independently of the WR treatment (Table 12). Irrigation application induced a significant increase in LAI in the driest year (2014). On the other hand, the pruning's fresh mass per vine was significantly increased by irrigation in both cultivars, while LLR did not induce any significant response from this parameter (Table 12). 


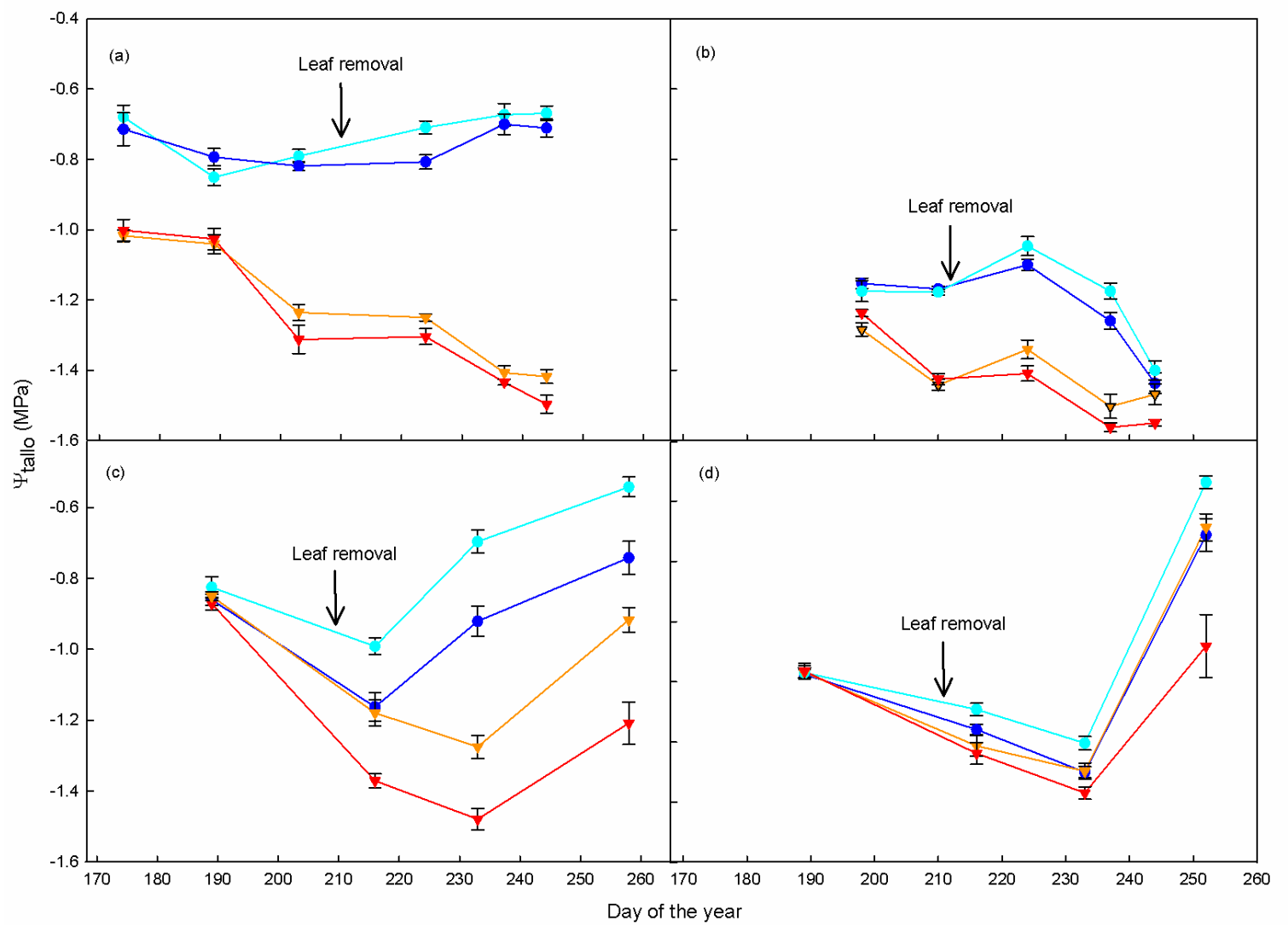

Figure 30. Effect of irrigated-undefoliated (IU; $\bullet$ ), irrigated-defoliated (ID; $)$ ), rainfedundefoliated (RU; $\nabla$ ) and rainfed-defoliated (RD; $\nabla$ ) treatments on the seasonal evolution of midday stem water potential $\left(\Psi_{\text {stem }}\right)$ of Bobal [(a) and (b)] and Tempranillo [(c) and (d)] vineyards in 2014 [(a) and (c)] and 2015 [(b) and (d)]. Data are averages and standard errors of 16 leaves per treatment and date. The date of application of defoliation is indicated by an arrow.

\section{Vine water status and leaf assimilation rates}

In both trials and seasons, vine water status was significantly affected by watering regime (WR) and canopy management (CM) (Figure 30). Differences in $\Psi_{\text {stem }}$ between irrigated and rainfed vines were more noticeable in Bobal than in Tempranillo. Interestingly, in both trials, the defoliated vines showed significantly less negative midday

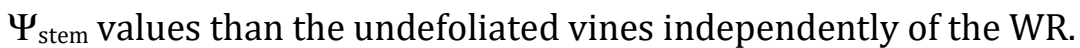

In both trials WR and CM treatments significantly-affected leaf stomatal conductance $\left(\mathrm{g}_{\mathrm{s}}\right)$, transpiration (E) and photosynthesis (A) (Figure 31). Significant reductions were observed in $\mathrm{g}_{\mathrm{s}}, \mathrm{E}$ and $\mathrm{A}$ in rainfed vines compared to irrigated vines, and in undefoliated (Control) vines compared to LLR vines. The observed effects were always statistically significant in the Bobal vineyard. In the Tempranillo plot, the differences among treatments 
were relatively smaller and, thus, in some cases, were not statistically significant. Irrigation negatively affected intrinsic water use efficiency $\left(A / g_{s}\right)$, whereas LLR did not have any significant effect on this physiological parameter (ranging from 50 to $62 \mu \mathrm{mol} \mathrm{CO} \mathrm{mol} \mathrm{H}_{2} \mathrm{H}^{-}$ 1 in Tempranillo and 46 to $60 \mu \mathrm{mol} \mathrm{CO}$ mol H2O$^{-1}$ in Bobal, on seasonal average).

\section{Yield components}

The effect of the watering regime (WR) on fruit yield was similar in both trials (Bobal and Tempranillo), whereas the effect of canopy management (CM) varied depending on the trial (Table 12). In the two vineyards, the effect of the interaction between the two experimental factors (CM and WR) was not significant for most of the yield components under study. In Tempranillo, both WR and CM affected fruit yield significantly, whereas in Bobal only WR significantly-influenced yield. In both trials, fruit yield increased significantly in response to irrigation, with seasonal average increments of $47 \%$ in Bobal and $24 \%$ in Tempranillo compared to rainfed vines (Table 12). The number of berries per cluster were not affected by the WR or CM (ranging from $77 \pm 4$ and $172 \pm 12$ in Bobal, and from $50 \pm 9$ and $117 \pm 11$ in Tempranillo, in 2014 and 2015, respectively).

Table 12. Values of yield components and vegetative growth in the trial established during 2014 and 2014 on Vitis vinifera L., cv. Bobal and Tempranillo trials at Requena, Valencia, Spain.

\begin{tabular}{|c|c|c|c|c|c|c|c|c|c|}
\hline \multirow[b]{2}{*}{ Parameter } & \multirow[b]{2}{*}{ Cultivar } & \multirow[b]{2}{*}{ Year } & \multicolumn{4}{|c|}{ Treatment } & \multicolumn{3}{|c|}{ Significance of effects } \\
\hline & & & IU & ID & $\overline{\mathrm{RU}}$ & $\overline{\mathbf{R D}}$ & $\overline{W R}$ & CM & $\mathrm{WR} \times \mathrm{CM}$ \\
\hline \multirow{4}{*}{$\begin{array}{l}\text { Fruit yield } \\
\left(\mathrm{Mg} \mathrm{ha}^{-1}\right)\end{array}$} & \multirow{2}{*}{ Bobal } & 2014 & $5.32 \mathrm{a}$ & $4.78 \mathrm{a}$ & $1.70 \mathrm{~b}$ & $2.03 \mathrm{~b}$ & $<0.001$ & 0.839 & 0.383 \\
\hline & & 2015 & $17.02 \mathrm{a}$ & $14.57 \mathrm{a}$ & $10.68 \mathrm{~b}$ & $10.88 \mathrm{~b}$ & $<0.001$ & 0.289 & 0.212 \\
\hline & \multirow{2}{*}{ Tempranillo } & 2014 & $2.48 \mathrm{a}$ & $2.08 a b$ & $1.87 \mathrm{bc}$ & $1.38 \mathrm{c}$ & 0.003 & 0.041 & 0.845 \\
\hline & & 2015 & $13.04 \mathrm{a}$ & $11.50 \mathrm{a}$ & $11.51 \mathrm{a}$ & $8.52 \mathrm{~b}$ & 0.019 & 0.018 & 0.446 \\
\hline \multirow{4}{*}{$\begin{array}{c}\text { Number of } \\
\text { clusters per } \\
\text { vine }\end{array}$} & \multirow{2}{*}{ Bobal } & 2014 & 5.3 & 4.9 & 5.5 & 4.9 & 0.745 & 0.330 & 0.845 \\
\hline & & 2015 & $11.5 \mathrm{a}$ & $10.9 \mathrm{ab}$ & $9.2 \mathrm{~b}$ & $10.0 \mathrm{ab}$ & 0.019 & 0.885 & 0.255 \\
\hline & \multirow{2}{*}{ Tempranillo } & 2014 & 14.7 & 12.8 & 15.4 & 12.3 & 0.921 & 0.137 & 0.641 \\
\hline & & 2015 & $26.1 \mathrm{a}$ & $28.7 \mathrm{a}$ & $24.6 \mathrm{ab}$ & $21.2 \mathrm{~b}$ & 0.005 & 0.819 & 0.069 \\
\hline \multirow{4}{*}{$\begin{array}{l}\text { Cluster fresh } \\
\text { mass } \\
\text { (g cluster-1) }^{-1}\end{array}$} & \multirow{2}{*}{ Bobal } & 2014 & $329 a$ & $282 a$ & $105 b$ & $125 b$ & $<0.001$ & 0.471 & 0.078 \\
\hline & & 2015 & $583 a$ & $498 a b$ & $447 \mathrm{~b}$ & $407 b$ & 0.003 & 0.092 & 0.545 \\
\hline & \multirow{2}{*}{ Tempranillo } & 2014 & $94 a$ & 81ab & $72 \mathrm{bc}$ & $62 c$ & 0.001 & 0.025 & 0.774 \\
\hline & & 2015 & $297 a$ & $238 b$ & $282 a$ & $227 b$ & 0.237 & $<0.001$ & 0.855 \\
\hline \multirow{4}{*}{$\begin{array}{l}\text { Berry fresh } \\
\text { mass } \\
\left.\text { (g berry }^{-1}\right)\end{array}$} & \multirow{2}{*}{ Bobal } & 2014 & $3.7 \mathrm{a}$ & $3.6 \mathrm{a}$ & $1.6 \mathrm{~b}$ & $1.6 \mathrm{~b}$ & $<0.001$ & 0.839 & 0.584 \\
\hline & & 2015 & $3.1 \mathrm{a}$ & $3.0 \mathrm{a}$ & $2.7 \mathrm{ab}$ & $2.56 \mathrm{~b}$ & 0.010 & 0.665 & 0.681 \\
\hline & \multirow{2}{*}{ Tempranillo } & 2014 & $1.5 \mathrm{ab}$ & $1.8 \mathrm{a}$ & $1.4 \mathrm{~b}$ & $1.3 \mathrm{~b}$ & 0.041 & 0.145 & 0.026 \\
\hline & & 2015 & $2.3 \mathrm{a}$ & $1.9 \mathrm{~b}$ & $2.2 \mathrm{a}$ & $2.0 \mathrm{~b}$ & 0.802 & $<0.001$ & 0.229 \\
\hline
\end{tabular}




\begin{tabular}{|c|c|c|c|c|c|c|c|c|c|}
\hline \multirow{4}{*}{$\begin{array}{c}\text { Shoot } \\
\text { fruitfulness } \\
\text { (number of } \\
\text { clusters shoot }^{-1} \text { ) }\end{array}$} & \multirow{2}{*}{ Bobal } & 2015 & $0.84 a$ & $0.80 \mathrm{ab}$ & $0.70 \mathrm{~b}$ & $0.74 \mathrm{ab}$ & 0.030 & 0.970 & 0.394 \\
\hline & & 2016 & $0.98 \mathrm{a}$ & $0.97 \mathrm{a}$ & $0.81 b$ & $0.94 \mathrm{ab}$ & 0.045 & 0.218 & 0.142 \\
\hline & \multirow{2}{*}{ Tempranillo } & 2015 & $1.20 \mathrm{a}$ & $1.27 \mathrm{a}$ & $1.20 \mathrm{a}$ & $0.99 \mathrm{~b}$ & 0.016 & 0.237 & 0.016 \\
\hline & & 2016 & $1.29 \mathrm{a}$ & $1.19 \mathrm{a}$ & $1.02 \mathrm{~b}$ & $1.14 \mathrm{a}$ & 0.279 & 0.056 & 0.001 \\
\hline \multirow{4}{*}{$\begin{array}{l}\text { Pruning mass/ } \\
\text { vine (g vine }{ }^{-1} \text { ) }\end{array}$} & \multirow{2}{*}{ Bobal } & 2014 & $507 a$ & $470 \mathrm{ab}$ & $302 b c$ & $272 c$ & 0.004 & 0.619 & 0.961 \\
\hline & & 2015 & $620 a$ & $571 \mathrm{ab}$ & $508 \mathrm{ab}$ & $470 \mathrm{~b}$ & 0.015 & 0.313 & 0.908 \\
\hline & \multirow{2}{*}{ Tempranillo } & 2014 & $628 a$ & $675 a$ & $403 b$ & $543 a b$ & 0.003 & 0.409 & 0.103 \\
\hline & & 2015 & - & - & - & - & - & - & - \\
\hline \multirow{4}{*}{$\begin{array}{c}\text { LAI } \\
\left(\mathrm{m}^{2} / \mathrm{m}^{2}\right)\end{array}$} & \multirow{2}{*}{ Bobal } & 2014 & $0.76 a$ & $0.62 \mathrm{~b}$ & $0.56 \mathrm{~b}$ & $0.45 c$ & $<0.001$ & $<0.001$ & 0.642 \\
\hline & & 2015 & $1.52 \mathrm{a}$ & $1.04 \mathrm{~b}$ & $1.50 \mathrm{a}$ & $0.99 \mathrm{~b}$ & 0.436 & $<0.001$ & 0.915 \\
\hline & \multirow{2}{*}{ Tempranillo } & 2014 & $0.87 a$ & $0.76 \mathrm{~b}$ & $0.65 c$ & $0.50 \mathrm{~d}$ & $<0.001$ & $<0.001$ & 0.511 \\
\hline & & 2015 & $0.72 \mathrm{a}$ & $0.56 \mathrm{~b}$ & $0.70 a$ & $0.53 \mathrm{~b}$ & 0.587 & $<0.001$ & 0.553 \\
\hline \multirow{4}{*}{$\begin{array}{c}\text { LA-to-fruit } \\
\text { ratio } \\
\left(\mathrm{m}^{2} / \mathrm{kg}\right)\end{array}$} & \multirow{2}{*}{ Bobal } & 2014 & $1.6 \mathrm{~b}$ & $2.3 \mathrm{~b}$ & $3.9 a$ & $2.0 \mathrm{~b}$ & 0.017 & 0.157 & 0.003 \\
\hline & & 2015 & $1.0 \mathrm{ab}$ & $0.8 \mathrm{~b}$ & $1.6 a$ & $0.9 \mathrm{~b}$ & 0.001 & $<0.001$ & 0.034 \\
\hline & \multirow{2}{*}{ Tempranillo } & 2014 & $2.8 \mathrm{~b}$ & $2.6 \mathrm{~b}$ & $3.9 a$ & $2.8 \mathrm{~b}$ & 0.082 & 0.083 & 0.302 \\
\hline & & 2015 & 0.7 & 0.6 & 0.7 & 0.6 & 0.584 & 0.133 & 0.706 \\
\hline
\end{tabular}

Data are the average treatment in 2014 and 2015, except for shoot fruitfulness which averages are for 2015 and 2016. Within each row, mean values followed by a different letter are significantly different at $P<0.05$. For data analysis between factors, the statistical significance effect of watering regime (WR), canopy management (CM) and their interaction are also indicated. LAI means leaf area index. Treatments are: IU, irrigated-undefoliated; ID, irrigated-defoliated; RU, rainfed-undefoliated; RD, rainfed-defoliated. 


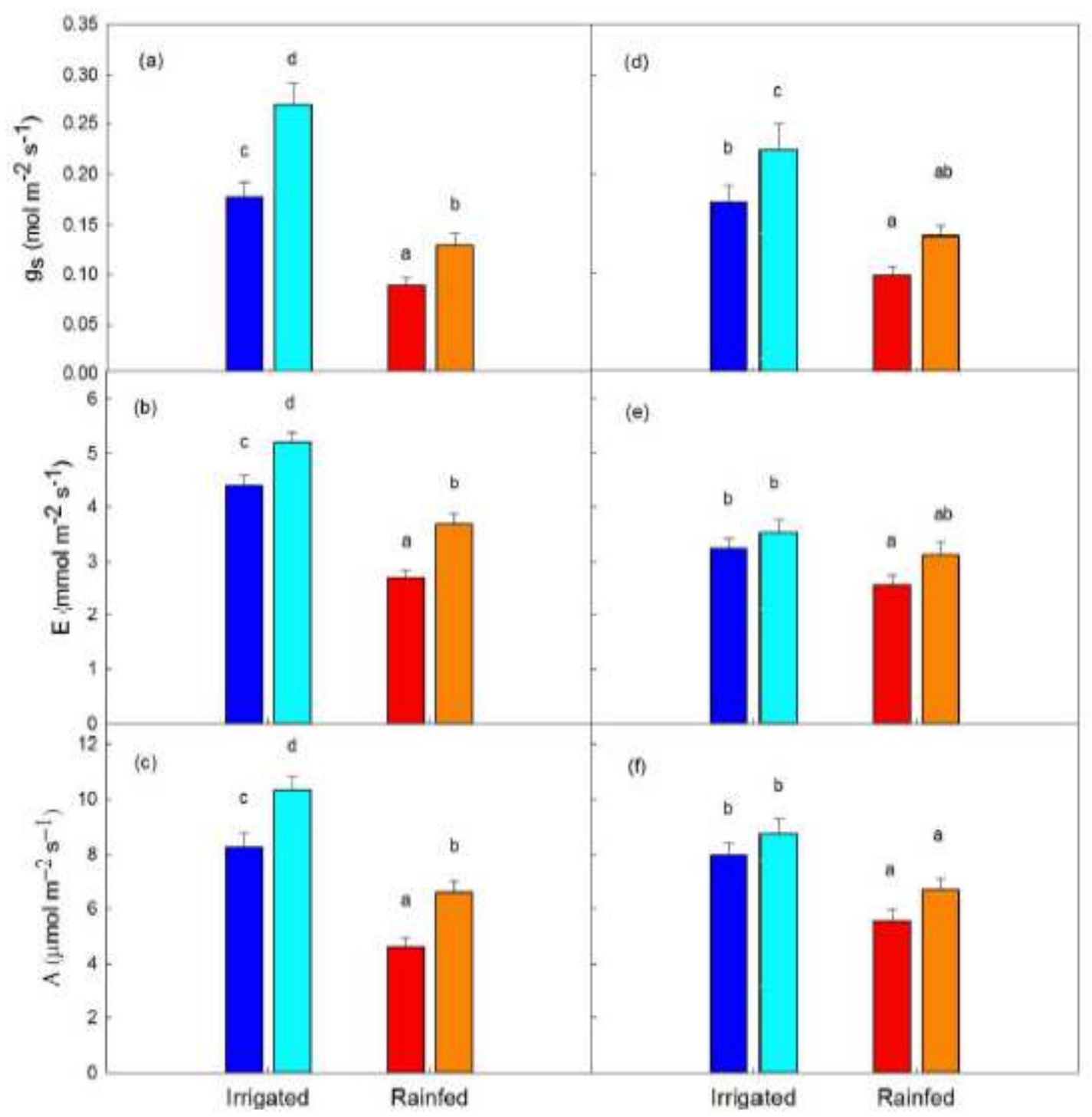

Figure 31. Effect on stomatal conductance $\left(\mathrm{g}_{\mathrm{s}}\right)$, transpiration $(\mathrm{E})$ and photosynthesis $(\mathrm{A})$ leaf rates of the irrigated-undefoliated (IU; $\square$ ), irrigated-defoliated (ID; $\square$ ), rainfedundefoliated (RU; $\square$ ) and rainfed-defoliated (RD; $\square$ ) treatments of Bobal [(a), (b) and (c)] and Tempranillo [(d), (e) and (f)] vineyards during the two experimental seasons. Data are averages and standard errors of 16 leaves per treatment and 3 dates per season. Different letters mean significant difference among treatments at $P<0.05$.

CM significantly affected cluster and berry fresh mass in the Tempranillo plot, whereas this was not the case for the Bobal trial. The pooling of yield data of Tempranillo vines across seasons within the same WR, revealed a significant reduction of $19 \%$ in LLR vines compared to that of undefoliated vines. In both seasons, the LLR reduced cluster fresh mass, whereas berry fresh mass was affected only in 2015. The seasonal pattern of berry fresh mass was more influenced by WR than CM (Figures 4 and 5). This was more evident in 2014, a dryer season, than in 2015. 
Table 13. The harvest date and must technological composition attributes at harvest of Vitis vinifera L., cv. Bobal and Tempranillo trials in the two seasons under different watering regime (WR) and canopy management (CM) in Requena, Valencia, Spain.

\begin{tabular}{|c|c|c|c|c|c|c|c|c|c|}
\hline \multirow[b]{2}{*}{ Parameter } & \multirow[b]{2}{*}{ Cultivar } & \multirow[b]{2}{*}{ Year } & \multicolumn{4}{|c|}{ Treatment } & \multicolumn{3}{|c|}{ Significances of effects } \\
\hline & & & IU & ID & $\mathbf{R C}$ & RD & WR & CM & $\mathrm{WR}^{*} \mathrm{CM}$ \\
\hline \multirow{8}{*}{$\begin{array}{l}\text { Harvest date } \\
\text { (DOY) }\end{array}$} & \multirow{4}{*}{ Bobal } & & 274 & 274 & 254 & 259 & - & - & - \\
\hline & & 2014 & {$[62]$} & {$[62]$} & [42] & {$[47]$} & & & \\
\hline & & & 272 & 294 & 260 & 280 & - & - & - \\
\hline & & 2015 & {$[61]$} & [83] & [49] & [69] & & & \\
\hline & \multirow{4}{*}{ Tempranillo } & & 246 & 254 & 254 & 254 & - & - & - \\
\hline & & 2014 & {$[36]$} & {$[44]$} & {$[44]$} & {$[44]$} & & & \\
\hline & & & 254 & 264 & 254 & 264 & - & - & - \\
\hline & & 2015 & {$[55]$} & {$[65]$} & [55] & [65] & & & \\
\hline \multirow{6}{*}{$\begin{array}{c}\text { TSS } \\
\text { (으ix) }\end{array}$} & \multirow{4}{*}{ Bobal } & & & 21.0 & & 24.3 & & & \\
\hline & & 2014 & $22.1 \mathrm{c}$ & $\mathrm{d}$ & $25.1 \mathrm{a}$ & $\mathrm{b}$ & $<0.001$ & $<0.001$ & 0.563 \\
\hline & & & & 18.6 & & 19.7 & & & \\
\hline & & 2015 & $20.2 \mathrm{a}$ & $\mathrm{b}$ & $20.6 \mathrm{a}$ & a & 0.024 & $<0.001$ & 0.237 \\
\hline & \multirow{2}{*}{ Tempranillo } & 2014 & 25.1 & 24.7 & 25.4 & 25.1 & 0.072 & 0.215 & 0.672 \\
\hline & & 2015 & 21.7 & 22.4 & 21.4 & 21.6 & 0.293 & 0.432 & 0.641 \\
\hline \multirow{4}{*}{ pH } & \multirow{2}{*}{ Bobal } & 2014 & 3.5 & 3.4 & 3.4 & 3.4 & 0.099 & 0.746 & 0.068 \\
\hline & & 2015 & $3.5 \mathrm{ab}$ & $3.6 \mathrm{a}$ & $3.4 \mathrm{~b}$ & $3.5 b$ & 0.005 & 0.059 & 0.494 \\
\hline & \multirow{2}{*}{ Tempranillo } & 2014 & $3.3 \mathrm{~b}$ & $3.5 a$ & $3.5 a$ & $3.5 a$ & $<0.001$ & $<0.001$ & 0.001 \\
\hline & & 2015 & $3.3 \mathrm{~b}$ & $3.7 \mathrm{a}$ & $3.2 \mathrm{~b}$ & $3.7 a$ & 0.384 & $<0.001$ & 0.104 \\
\hline \multirow{5}{*}{$\begin{array}{c}\text { TA } \\
\text { (g/L tartaric } \\
\text { acid) }\end{array}$} & \multirow{3}{*}{ Bobal } & & & $4.8 \mathrm{a}$ & & $4.9 a$ & & & \\
\hline & & 2014 & $5.0 \mathrm{a}$ & $\mathrm{b}$ & $4.5 b$ & $\mathrm{~b}$ & 0.210 & 0.358 & 0.054 \\
\hline & & 2015 & $4.9 \mathrm{c}$ & $4.8 \mathrm{c}$ & $5.9 a$ & $5.5 b$ & $<0.001$ & 0.025 & 0.056 \\
\hline & \multirow{2}{*}{ Tempranillo } & 2014 & $4.2 \mathrm{a}$ & $3.6 \mathrm{c}$ & $4.0 \mathrm{~b}$ & $3.9 \mathrm{~b}$ & 0.290 & $<0.001$ & $<0.001$ \\
\hline & & 2015 & 5.6 & 5.5 & 5.6 & 5.7 & 0.265 & 0.989 & 0.446 \\
\hline \multirow{4}{*}{$\begin{array}{c}\text { Tartaric acid } \\
\text { concentration } \\
(\mathrm{g} / \mathrm{L})\end{array}$} & \multirow{2}{*}{ Bobal } & 2014 & $1.8 \mathrm{c}$ & $1.6 \mathrm{~d}$ & $3.9 b$ & $4.7 a$ & $<0.001$ & $<0.001$ & $<0.001$ \\
\hline & & 2015 & $2.5 \mathrm{c}$ & $2.4 \mathrm{c}$ & $4.7 \mathrm{a}$ & $4.0 \mathrm{~b}$ & $<0.001$ & $<0.001$ & $<0.001$ \\
\hline & \multirow{2}{*}{ Tempranillo } & 2014 & $4.0 \mathrm{a}$ & $3.6 \mathrm{~b}$ & $4.0 \mathrm{a}$ & $4.0 \mathrm{a}$ & $<0.001$ & $<0.001$ & $<0.001$ \\
\hline & & 2015 & $4.1 \mathrm{bc}$ & $4.0 \mathrm{c}$ & $4.2 \mathrm{ab}$ & $4.4 \mathrm{a}$ & $<0.001$ & 0.805 & 0.036 \\
\hline \multirow{4}{*}{$\begin{array}{c}\text { Malic acid } \\
\text { concentration } \\
(\mathrm{g} / \mathrm{L})\end{array}$} & \multirow{2}{*}{ Bobal } & 2014 & 3.0a & $3.0 \mathrm{a}$ & $1.9 b$ & $1.6 \mathrm{~b}$ & 0.090 & $<0.001$ & 0.230 \\
\hline & & 2015 & 2.7 & 2.6 & 2.7 & 2.5 & 0.524 & 0.082 & 0.307 \\
\hline & \multirow{2}{*}{ Tempranillo } & 2014 & $2.0 \mathrm{ab}$ & $1.9 \mathrm{~b}$ & $2.0 \mathrm{ab}$ & $2.1 \mathrm{a}$ & 0.060 & 0.588 & 0.124 \\
\hline & & 2015 & 2.8 & 2.8 & 2.9 & 2.9 & 0.070 & 0.965 & 0.567 \\
\hline
\end{tabular}

Data are the average values for 2014 and 2015 ( $n=6$ in Bobal; $n=8$ in Tempranillo). Values between brackets means ripening duration expressed in days from veraison to the harvest date. Within each row, mean values followed by a different letter are significantly different at $\mathrm{P}<0.05$. TSS, total soluble solids, TA, titratable acidity. Treatments are: IU, irrigatedundefoliated; ID, irrigated-defoliated; RU, rainfed-undefoliated; RD, rainfed-defoliated. 
The LA-to-fruit ratio during the ripening period was significantly higher during the first season in both trials (Table 12). In the Bobal trial, the LLR and the irrigation tended to significantly-reduce the LA-to-fruit ratio. However, in the Tempranillo trial, the effect of the experimental treatments on this ratio was not fully consistent because both yield and LA were significantly constrained as compared to undefoliated vines.

Grape ripening

In both trials, berry ripening was significantly affected by WR and CM treatments (Figures 4 and 5) and this was translated into differences in berry composition at harvest (Tables 3 and 4). Despite our goal being the harvesting of grapes from all the treatments at similar TSS values, in the Bobal trial this was not possible because of the occurrence of leaf senescence induced by the IU and ID treatments.

The WR affected the dynamics of TSS accumulation in the berries, but these effects were opposite in the two trials. In the Bobal trial, since the very beginning of the ripening period, irrigation delayed the increase in berry TSS concentration (Figures 4C and 4D), while in the Tempranillo trial, irrigation had a slightly opposite effect (Figures 5C and 5D). In both trials, rainfed treatments showed higher berry juice TA around veraison (Figures $4 \mathrm{E}, 4 \mathrm{~F}, 5 \mathrm{E}$ and $5 \mathrm{~F}$ ), but at harvest the effect of the CM and WR on TA was less clear (Table 13). Overall, a decreasing trend of TA in response to harvest delay was perceived, whereas the opposite effect was observed in must $\mathrm{pH}$. These effects were more evident in Tempranillo than in Bobal grapes. Thus, the relationship between TSS to TA during ripening was calculated to unravel the effect of the treatments on TA at equal levels of TSS (Figure 34). This elucidates that irrigation and LLR had a tendency to reduce TA, although this effect becomes less clear near harvest.

Table 14. Berry phenolic composition attributes at harvest of Vitis vinifera L., cv. Bobal and Tempranillo trials in the two seasons under different watering regime (WR) and canopy management (CM) in Requena, Valencia, Spain.

\begin{tabular}{|c|c|c|c|c|c|c|c|c|c|}
\hline \multirow[b]{2}{*}{ Parameter } & \multirow[b]{2}{*}{ Cultivar } & \multirow[b]{2}{*}{ Year } & \multicolumn{4}{|c|}{ Treatment } & \multicolumn{3}{|c|}{ Significance of effects } \\
\hline & & & IC & ID & RU & RD & WR & $\mathbf{C M}$ & WR*CM \\
\hline \multirow{5}{*}{$\begin{array}{c}\text { Maturity } \\
\text { index } \\
\text { (o-Brix/g/L) }\end{array}$} & \multirow{2}{*}{ Bobal } & 2014 & $4.5 \mathrm{c}$ & $4.4 \mathrm{c}$ & $5.6 \mathrm{a}$ & $5.0 \mathrm{~b}$ & $<0.001$ & 0.027 & 0.059 \\
\hline & & 2015 & $4.2 \mathrm{~d}$ & $3.8 \mathrm{c}$ & $3.5 \mathrm{a}$ & $3.6 \mathrm{~b}$ & $<0.001$ & 0.800 & 0.002 \\
\hline & \multirow{2}{*}{ Tempranillo } & 2014 & $5.9 \mathrm{c}$ & $6.8 \mathrm{a}$ & $6.3 b$ & $6.4 \mathrm{~b}$ & 0.934 & $<0.001$ & $<0.001$ \\
\hline & & 2015 & 3.9 & 4.1 & 3.8 & 3.8 & 0.732 & 0.298 & 0.919 \\
\hline & Bobal & 2014 & $0.93 \mathrm{~b}$ & $0.83 \mathrm{~b}$ & $1.74 \mathrm{a}$ & $1.79 \mathrm{a}$ & $<0.001$ & 0.628 & 0.161 \\
\hline
\end{tabular}




\begin{tabular}{|c|c|c|c|c|c|c|c|c|c|}
\hline \multirow{3}{*}{$\begin{array}{c}\text { Anthocyanins } \\
\text { (mg/g) }\end{array}$} & & 2015 & $0.48 \mathrm{~d}$ & $0.62 \mathrm{c}$ & $1.08 \mathrm{a}$ & $0.71 b$ & $<0.001$ & 0.006 & $<0.001$ \\
\hline & \multirow{2}{*}{ Tempranillo } & 2014 & $1.49 \mathrm{a}$ & $1.16 \mathrm{~b}$ & $1.46 \mathrm{a}$ & $1.50 \mathrm{a}$ & 0.067 & 0.082 & 0.028 \\
\hline & & 2015 & $0.98 \mathrm{a}$ & $0.83 \mathrm{~b}$ & $0.98 \mathrm{a}$ & $0.82 \mathrm{~b}$ & 0.960 & 0.008 & 0.960 \\
\hline \multirow{4}{*}{$\begin{array}{l}\text { Polyphenols } \\
\text { (mg/g) }\end{array}$} & \multirow{2}{*}{ Bobal } & 2014 & $2.10 \mathrm{c}$ & $1.91 \mathrm{c}$ & $2.81 \mathrm{~b}$ & $3.43 a$ & $<0.001$ & 0.039 & 0.009 \\
\hline & & 2015 & $1.60 \mathrm{c}$ & $2.13 \mathrm{~b}$ & $2.55 \mathrm{a}$ & $2.41 \mathrm{a}$ & $<0.001$ & 0.071 & 0.004 \\
\hline & \multirow{2}{*}{ Tempranillo } & 2014 & $2.96 \mathrm{a}$ & $2.47 \mathrm{~b}$ & $2.95 a$ & $3.09 \mathrm{a}$ & 0.009 & 0.103 & 0.008 \\
\hline & & 2015 & 2.70 & 2.46 & 2.62 & 2.63 & 0.627 & 0.194 & 0.153 \\
\hline \multirow{4}{*}{$\begin{array}{c}\text { Anthocyanins- } \\
\text { to-sugars } \\
\text { ratio } \\
\text { (mg/g/o Brix) }\end{array}$} & \multirow{2}{*}{ Bobal } & 2014 & $0.04 b$ & $0.04 \mathrm{~b}$ & $0.07 a$ & $0.07 a$ & $<0.001$ & 0.671 & 0.119 \\
\hline & & 2015 & $0.01 \mathrm{c}$ & $0.03 \mathrm{~b}$ & $0.05 a$ & $0.04 \mathrm{~b}$ & $<0.001$ & 0.713 & $<0.001$ \\
\hline & \multirow{2}{*}{ Tempranillo } & 2014 & $0.06 a$ & $0.05 b$ & $0.06 a$ & $0.06 a$ & 0.094 & 0.119 & 0.022 \\
\hline & & 2015 & $0.05 a$ & $0.04 \mathrm{~b}$ & $0.05 a$ & $0.04 \mathrm{~b}$ & 0.630 & $<0.001$ & 0.968 \\
\hline
\end{tabular}

Data are the average values for 2014 and 2015 ( $n=6$ in Bobal; $n=8$ in Tempranillo). Within each row, mean values followed by a different letter are significantly different at $\mathrm{P}<0.05$. TSS, total soluble solids, TA, titratable acidity. Treatments are: IU, irrigatedundefoliated; ID, irrigated-defoliated; RU, rainfed-undefoliated; RD, rainfed-defoliated.

In both trials, tartaric acid concentration at harvest tended to be higher in rainfed than in irrigated vines. This effect was particularly clear in the Bobal trial (Table 13). The effect of LLR on tartaric acid concentration was inconsistent in both cultivars. In Bobal, malic acid concentrations in berry juice was affected by the irrigation applied only in the first season, when berries from the IU and ID treatments did not reach sugar concentration similar to RU and RD berries. In Tempranillo, neither WR nor CM had a clear effect on berry malic acid concentration. In the Bobal trial, LLR did not affect berry malic acid concentration at harvest.

In the Bobal trial, the effect of $\mathrm{CM}$ on phenolic composition at harvest was not consistent between seasons (Table 14). Indeed in 2014, for each watering regime LLR did not affect berry phenolic concentration, whereas in 2015 the ID treatment induced an increase in berry anthocyanins and polyphenols. The opposite effects were found under rainfed conditions (Table 14). On the other hand, in the Tempranillo trial in both seasons, the LLR treatments induced a significant decrease in anthocyanin concentration at harvest with the only exception of RD in 2014 (Table 14). In both trials, during ripening, the LLR treatments caused a decrease in anthocyanin accumulation rate compared to undefoliated vines (Figures 3G, 3H, 4G and 4H). On the other hand, for both trials, the irrigated treatments significantly decreased anthocyanin and polyphenol concentration in the berries compared to rainfed vines. These effects were more evident in Bobal than in Tempranillo grapevines.

Anthocyanins-to-sugars ratio tended to be higher in the grapes of rainfed than irrigated vines (Table 14). This effect was less evident in the Tempranillo trial in 2015. Leaf 
removal induced a decrease in the anthocyanins-to-sugars ratio in Tempranillo trial, without a significant effect in Bobal. Even if LLR vines were harvested later than undefoliated vines, grape anthocyanin concentration was lower than in the undefoliated vines. In addition, it should be noted that the LLR slightly decreased the anthocyanin content per berry in both trials.

Wine composition

To assess treatment effects on wine composition, the alcohol content was used as a covariate aiming to analyse its influence on the extractability of phenolic components (Table 15). In both Bobal and Tempranillo trials, LLR did not cause any seasonallyconsistent effect on the total acidity (TA). It should be highlighted that TA was higher in Bobal wines made with the rainfed grapes compared to irrigated treatments. This effect was not observed in the Tempranillo wines. In both trials, wine $\mathrm{pH}$ was similar among treatments. 


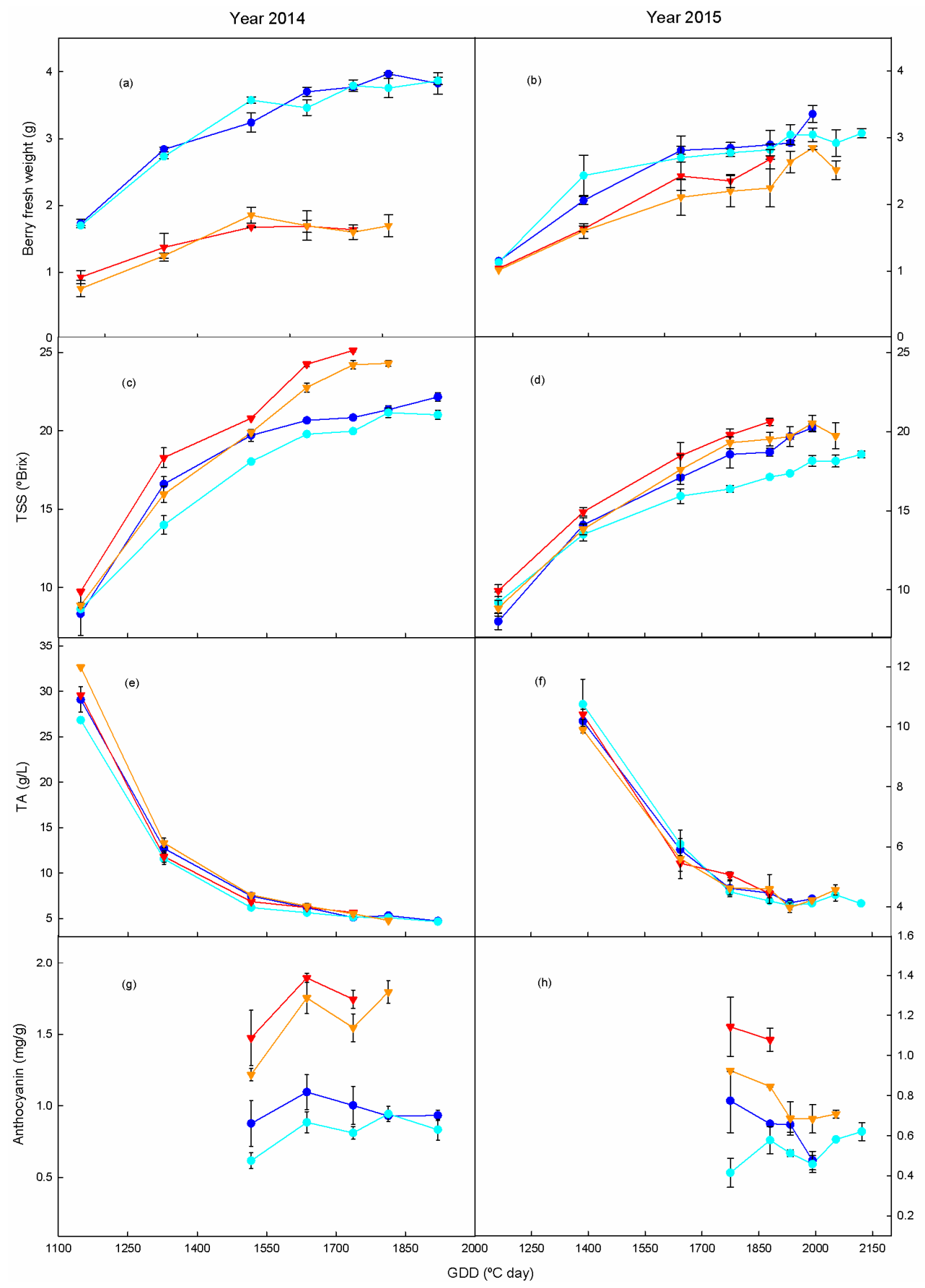

Figure 32. Bobal trial: grape effects on the seasonal evolution of berry fresh weight in 2014 (a) and in 2015 (b), total soluble solids (TSS) in 2014 (c) and in 2015 (d), titratable acidity in 2014 (e) and in 2015 (f), and anthocyanins concentration in 2014 (g) and in 2015 (h) in irrigated-undefoliated (IU; $\bullet$ ), irrigated-defoliated (ID; $\bigcirc$ ), rainfed-undefoliated (RU; $\nabla$ ) and rainfed-undefoliated (RD; $\nabla$ ) vines from the date of late leaf removal was applied until harvest. Data are the averages and standard errors of three replications per treatment for each date. GDD, growing degree days. 


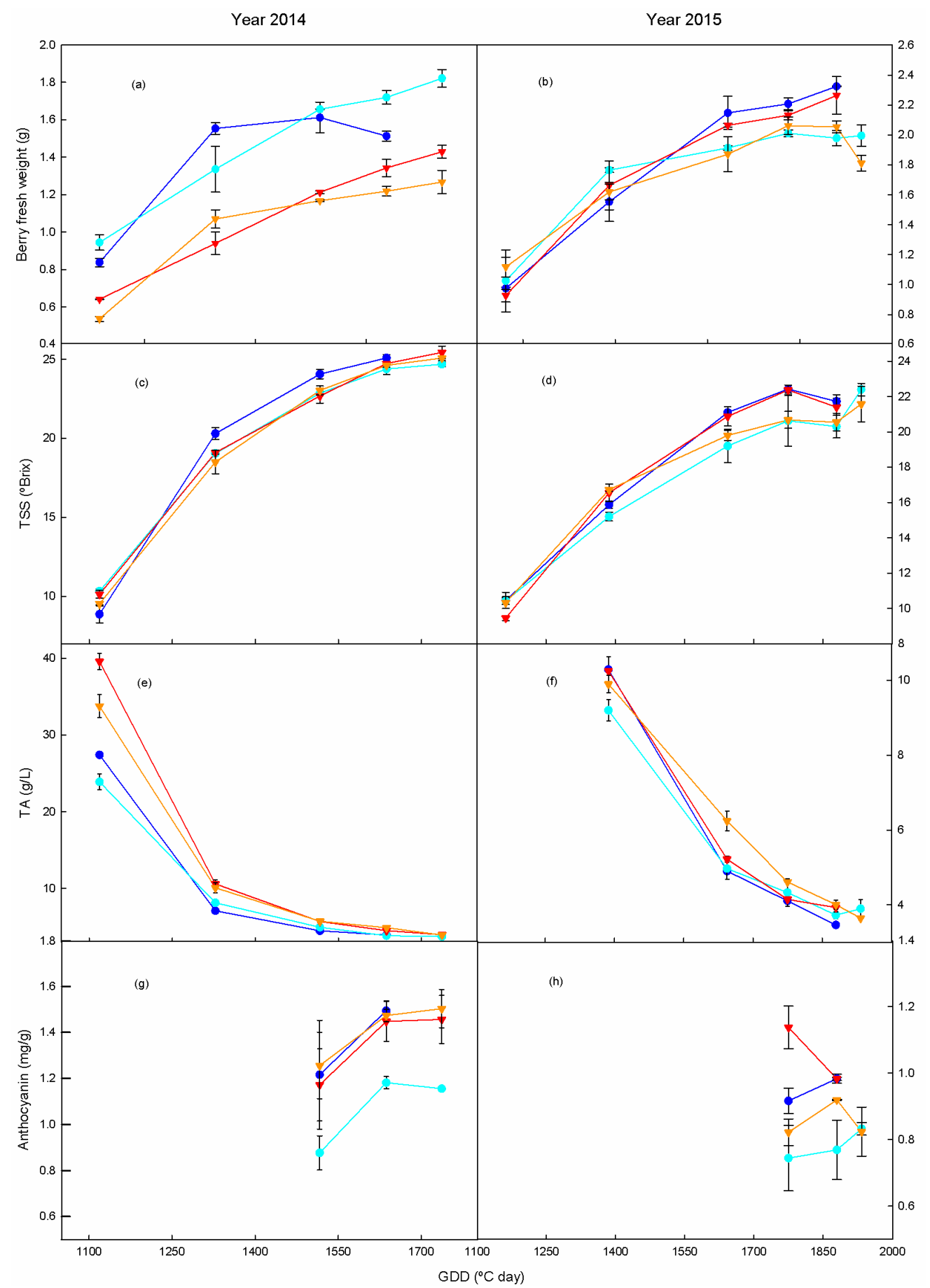

Figure 33. Tempranillo trial: grape effects on the seasonal evolution of (a) berry fresh weight in 2014 and (b) in 2015, (c) total soluble solids (TSS) in 2014 and (d) in 2015, (e) titratable acidity in 2014 and (f) in 2015, and (g) anthocyanins concentration in 2014 and (h) in 2015 of the irrigated-undefoliated (IU; O), irrigated-defoliated (ID; 0 ), rainfedundefoliated (RU; $\nabla$ ) and rainfed-defoliated (RD; $\nabla$ ) treatments from the date of late leaf removal was applied until harvest. Data are the average of four replications per treatment for each date. GDD, growing degree days. 
LLR tended to decrease wine colour intensity of both cultivars. Bobal wines made in 2014 were an exception, as an interactive effect was found due to the lower colour of RU wines than RD. There were no effects of WR on the colour of Tempranillo wines. However, irrigation significantly decreased colour intensity in wines made from Bobal grapes compared to the ones made from rainfed vines. Similar differences were found in wine anthocyanin concentration and TPI in both trials. In addition, in both trials and seasons, the hue angle of wines increased in response to LLR, with the only exception of Bobal RU wines from 2014. Irrigation also increased the hue angle of Bobal wines, while in the wines made from the Tempranillo trial this parameter was not affected by the WR.

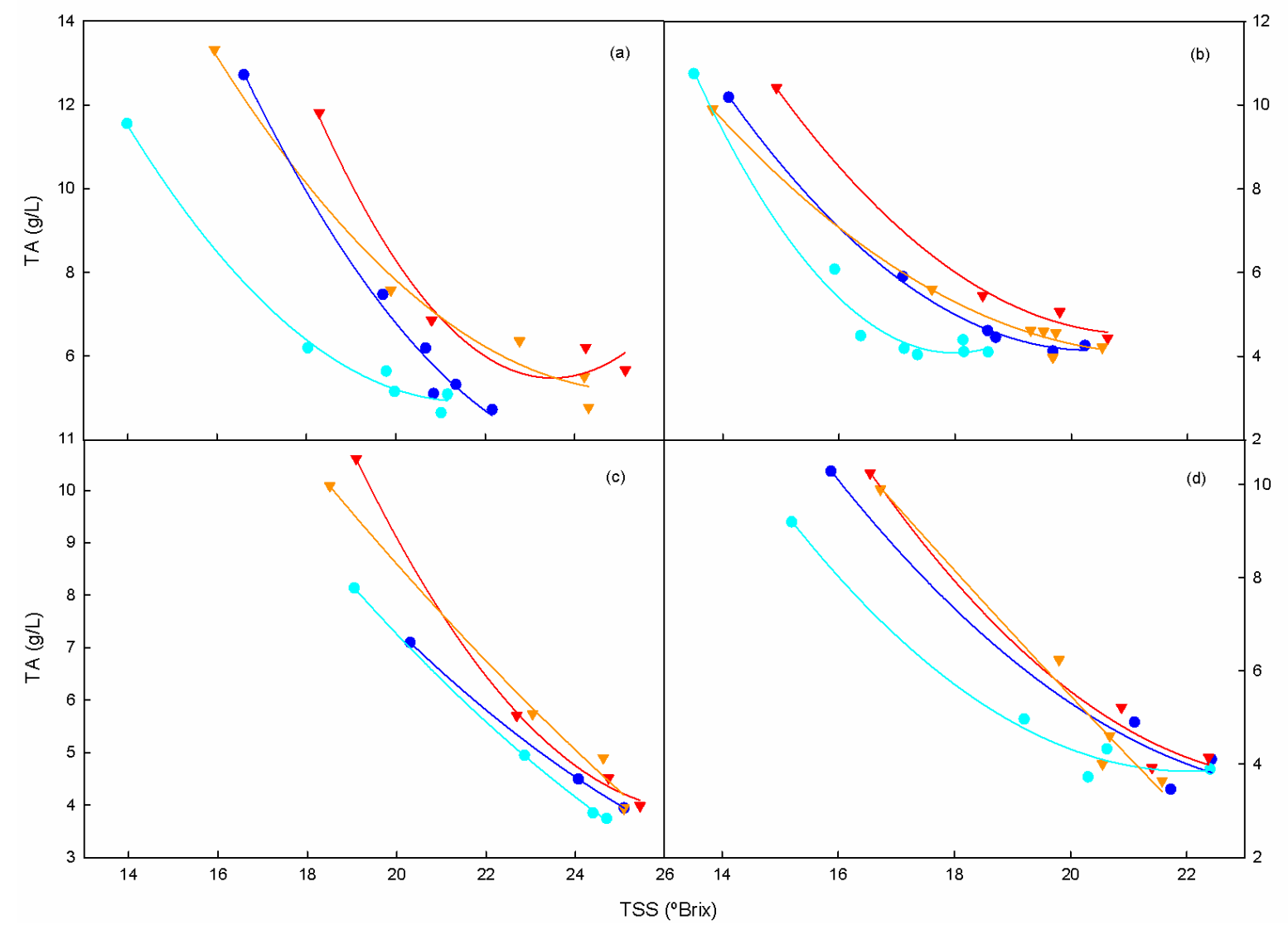

Figure 34. Effect of irrigated Control (IU; $\odot$ ), irrigated defoliated (ID; $\odot$ ), rainfed control $(\mathrm{RU} ; \boldsymbol{\nabla})$ and rainfed defoliated (RD; $\nabla$ ) treatments on the relationship between total soluble solids (TSS) accumulation in berries and titratable acidity (TA) for (a) Bobal plot in 2014 and (b) in 2015, (c) Tempranillo plot in 2014 and (d) in 2015. Data are averages of three replications per treatment in Bobal and four in Tempranillo for each date. 
Table 15. Seasonal values of wine composition parameters made of Bobal and Tempranillo winegrapes subjected to different watering regime and canopy management factors in Requena, Valencia, Spain.

\begin{tabular}{|c|c|c|c|c|c|c|c|c|c|}
\hline \multirow[b]{2}{*}{ Parameter } & \multirow[b]{2}{*}{ Cultivar } & \multirow[b]{2}{*}{ Year } & \multicolumn{4}{|c|}{ Treatment } & \multicolumn{3}{|c|}{ Significance of effects } \\
\hline & & & IU & ID & $\mathbf{R U}$ & RD & $\begin{array}{l}\mathbf{W R} \\
\end{array}$ & CM & $\mathrm{WR}^{*} \mathrm{CM}$ \\
\hline \multirow{4}{*}{$\begin{array}{c}\text { TA } \\
\text { (g/L tartaric } \\
\text { acid) }\end{array}$} & \multirow{2}{*}{ Bobal } & 2014 & $4.8 \mathrm{~b}$ & $4.9 \mathrm{~b}$ & $5.0 \mathrm{~b}$ & $6.0 \mathrm{a}$ & $<0.001$ & $<0.001$ & 0.007 \\
\hline & & 2015 & $4.2 \mathrm{~b}$ & $4.4 \mathrm{~b}$ & $4.9 \mathrm{a}$ & $5.2 \mathrm{a}$ & $<0.001$ & 0.045 & 0.749 \\
\hline & \multirow{2}{*}{ Tempranillo } & 2014 & $4.9 \mathrm{ab}$ & $4.6 \mathrm{~b}$ & $5.3 a$ & $4.6 \mathrm{~b}$ & 0.307 & 0.009 & 0.251 \\
\hline & & 2015 & $4.0 \mathrm{~b}$ & $4.2 \mathrm{a}$ & $4.1 \mathrm{~b}$ & $4.0 \mathrm{ab}$ & 0.691 & 0.012 & 0.466 \\
\hline \multirow{4}{*}{ pH } & \multirow{2}{*}{ Bobal } & 2014 & $3.7 \mathrm{ab}$ & $3.7 \mathrm{ab}$ & $3.8 \mathrm{a}$ & $3.6 \mathrm{~b}$ & 1 & 0.022 & 0.078 \\
\hline & & 2015 & $3.7 \mathrm{a}$ & $3.7 \mathrm{ab}$ & $3.6 \mathrm{ab}$ & $3.6 \mathrm{~b}$ & 0.023 & 0.359 & 0.783 \\
\hline & \multirow{2}{*}{ Tempranillo } & 2014 & $3.9 \mathrm{~b}$ & $4.0 \mathrm{a}$ & $4.0 \mathrm{ab}$ & $4.0 \mathrm{a}$ & 0.058 & 0.038 & 0.574 \\
\hline & & 2015 & 3.8 & 3.8 & 3.9 & 3.9 & 0.372 & 0.057 & 0.280 \\
\hline \multirow{4}{*}{$\begin{array}{c}\text { Colour } \\
\text { intensity }\end{array}$} & \multirow{2}{*}{ Bobal } & 2014 & $8.88 \mathrm{bc}$ & $8.86 \mathrm{c}$ & $11.5 \mathrm{~b}$ & $13.99 a$ & 0.006 & 0.025 & 0.116 \\
\hline & & 2015 & $5.10 \mathrm{~b}$ & $3.25 \mathrm{c}$ & $8.59 \mathrm{a}$ & $6.23 \mathrm{~b}$ & $<0.001$ & 0.003 & 0.697 \\
\hline & \multirow{2}{*}{ Tempranillo } & 2014 & $12.69 a$ & $10.28 \mathrm{c}$ & $11.67 \mathrm{~b}$ & $11.33 \mathrm{~b}$ & 0.964 & 0.002 & 0.002 \\
\hline & & 2015 & $6.85 a$ & $6.44 \mathrm{~b}$ & $7.90 \mathrm{a}$ & $6.42 \mathrm{~b}$ & 0.957 & $<0.001$ & 0.917 \\
\hline \multirow{4}{*}{$\begin{array}{l}\text { Anthocyanins } \\
\text { (mg/L) }\end{array}$} & \multirow{2}{*}{ Bobal } & 2014 & $404.2 \mathrm{a}$ & $423.3 a$ & $266.5 \mathrm{~b}$ & $459.7 a$ & 0.323 & 0.001 & 0.003 \\
\hline & & 2015 & $281.6 \mathrm{~b}$ & $197.6 \mathrm{c}$ & $347.0 \mathrm{a}$ & $273.2 b$ & $<0.001$ & $<0.001$ & 0.735 \\
\hline & \multirow{2}{*}{ Tempranillo } & 2014 & 396.7 & 332.2 & 406.6 & 380.3 & 0.360 & 0.128 & 0.503 \\
\hline & & 2015 & $457.4 \mathrm{a}$ & $325.3 b$ & $471.4 \mathrm{a}$ & $315.7 \mathrm{~b}$ & 0.820 & $<0.001$ & 0.243 \\
\hline \multirow{4}{*}{ TPI (AU) } & \multirow{2}{*}{ Bobal } & 2014 & $48.8 \mathrm{a}$ & $47.9 \mathrm{a}$ & $34.6 \mathrm{~b}$ & $46.9 a$ & 0.064 & 0.002 & 0.003 \\
\hline & & 2015 & $44.6 \mathrm{~b}$ & $35.4 \mathrm{c}$ & $50.5 a$ & $48.5 \mathrm{a}$ & $<0.001$ & $<0.001$ & 0.009 \\
\hline & \multirow{2}{*}{ Tempranillo } & 2014 & $48.4 \mathrm{ab}$ & $44.0 \mathrm{~b}$ & $50.5 a$ & $49.6 \mathrm{ab}$ & 0.069 & 0.155 & 0.341 \\
\hline & & 2015 & $53.9 a$ & $47.6 \mathrm{~b}$ & $51.9 \mathrm{a}$ & $44.1 \mathrm{c}$ & $<0.001$ & 0.004 & $<0.001$ \\
\hline \multirow{4}{*}{ Hue angle } & \multirow{2}{*}{ Bobal } & 2014 & $0.63 a$ & $0.62 \mathrm{a}$ & $0.60 \mathrm{a}$ & $0.51 \mathrm{~b}$ & $<0.001$ & $<0.001$ & $<0.001$ \\
\hline & & 2015 & $0.70 \mathrm{~b}$ & $0.80 \mathrm{a}$ & $0.59 \mathrm{c}$ & $0.63 \mathrm{ab}$ & $<0.001$ & 0.009 & 0.261 \\
\hline & \multirow{2}{*}{ Tempranillo } & 2014 & $0.70 \mathrm{~b}$ & $0.71 \mathrm{ab}$ & $0.69 \mathrm{~b}$ & $0.74 a$ & 0.234 & 0.043 & 0.094 \\
\hline & & 2015 & $0.64 \mathrm{~b}$ & $0.69 a$ & $0.64 \mathrm{~b}$ & $0.69 \mathrm{a}$ & 0.826 & $<0.001$ & 0.718 \\
\hline
\end{tabular}

Data are the average values for 2014 and 2015 ( $n=3$ in Bobal; $n=4$ in Tempranillo). Within each row, mean values followed by a different letter are significantly different at $\mathrm{P}<0.05$. For data analysis between factors, the statistical significance effect of watering regime (WR), canopy management (CM) and their interaction are also indicated. TA, titratable acidity; TPI, total polyphenols index. Treatments are: IU, irrigated-undefoliated; ID, irrigateddefoliated; RU, rainfed-undefoliated; RD, rainfed-defoliated. 


\section{Discussion}

In both the Tempranillo and Bobal trials, late leaf removal (LLR) and irrigation affected berry composition at harvest influencing grape ripening rate rather than delaying the onset of ripening (veraison). In general, vine phenology was not modified neither by canopy management (CM) nor by the watering regime (WR).

A delay in harvest did not imply an improvement in the balance between technological and phenolic grape ripeness per se. Furthermore, in Bobal, a mid-late season maturing cultivar, the delay in berry-ripening induced by LLR, and particularly by irrigation, indeed resulted detrimental because berries could not reach the same technological maturity of berries than the rainfed and undefoliated vines (Table 13). Indeed, under the experimental conditions of the present trials, the hypothesis of higher phenolic biosynthesis at slightly cooler temperatures was not confirmed. This could be explained because the thermal threshold above which anthocyanin biosynthesis is limited or even anthocyanin degradation is enhanced was not exceeded in our study. Despite the maximum temperature at the experimental site being above $33^{\circ} \mathrm{C}$ during the core of the ripening period (Figure 28), the day-night thermal difference in all treatments was below the upper limit of the threshold for optimum skin pigment biosynthesis (Mori et al. 2007, Movahed et al. 2016). However, it is also possible that the severe defoliation applied in our study limited polyphenols biosynthesis to a degree than TSS. That is, the vines prioritized the synthesis of primary metabolites rather than secondary. This is in agreement with the results reported by Bobeica et al. (2015) and could be supported by the fact that the increase in net $\mathrm{CO}_{2}$ assimilation rate measured in both trials in defoliated vines did not appear to be enough to fully compensate for the reduction in total vine leaf area. On average, the defoliation treatment induced an increase in leaf net photosynthetic rates of 25 and $13 \%$ for Bobal and Tempranillo, respectively (Figure 23), whereas the reductions in total vine leaf area induced by LLR were always above 23 and 21\% in Bobal and Tempranillo, respectively (Table 11). Nonetheless, net photosynthetic rate of young leaves retained in the undefoliated vines was expected to be much higher than its basal leaves rates (Poni et al. 1994).

The physiological reasons behind the increase in leaf gas exchange activity in response to defoliation are probably related to the fact that LLR promoted an alleviation of water stress, which was indeed an expected adaptive response (Petrie et al. 2003, Poni et al. 2013). Despite this improvement in vine water status (higher $\Psi_{\text {stem }}$ ), none of the 
treatments stimulated the growth of shoot tips or laterals, which would have enhanced the competition for photoassimilates with the berries (McCarthy 1997, Baeza et al. 2007). However, the increase in leaf net photosynthetic rate seems to have been sufficient, at least in the Bobal trial, for maintaining the yield levels of the defoliated treatments at similar values than the undefoliated vines (Table 12). This was observed even in the second experimental season, after two years of consecutive leaf pulling applications and under the higher crop levels in general registered in 2015. In the Tempranillo trial, however, the photosynthesis compensation observed in the LLR treatments did not palliate the reductions in cluster and berry fresh mass. On the other hand, berry number per cluster was unaffected by treatments in both trials, discarding possible carry-over effects due to carbohydrate depletion. This suggests that flower formation and fruit set was primarily controlled by the environment and not by the management of cultivation factors, such as CM or WR.

The experiment was not designed to elucidate the effects of irrigation regime on vine performance and grape composition, because these aspects have already been the focus of an extensive body of previous research in both Bobal and Tempranillo cultivars in the same area (Mirás-Avalos and Intrigliolo 2017). However, there are still some insights that must be noted. As expected, vine water status, leaf transpiration, photosynthesis and stomatal conductance were improved in response to moderate irrigation. But more interestingly, the intrinsic water-use efficiency was higher in the rainfed than in the irrigated vines. In fact, the observed stomatal conductance values in the rainfed vines of both trials were similar to the optimum values suggested by (Cifre et al. 2005) for increasing water use efficiency in grapevines (0.05- $0.15 \mathrm{~mol} \mathrm{~m}^{-2} \mathrm{~s}^{-1}$ ). Nevertheless, intrinsic WUE determinations from single leaf measurements could mask or alter conclusions made about the adaptive response of the whole canopy to water stress (Poni et al. 2014a).

In both trials, even in the rainfed vines, midday $\Psi_{\text {stem }}$ did not decrease below - $1.5 \mathrm{MPa}$, a value considered as the physiological threshold for efficient deficit-irrigation management under similar conditions (Intrigliolo and Castel 2008, Romero et al. 2010b, Castel et al. 2012). Another interesting aspect to consider is the different response to water availability of grape-ripening dynamics found in the Bobal and Tempranillo trials (Figure 32 and 33). Severe water stress, as in the rainfed treatments, detrimentally affected berry sugar accumulation in Tempranillo, while the opposite effect was found for Bobal. The present results seem to confirm previous research carried out over a single season by Salón et al. (2004) reporting how supplemental post-veraison irrigation differentially-affected grape- 
ripening in these cultivars. Indeed, the vine water stress effect on TSS depends on the cultivar and on the severity of water stress. For instance, Schultz and Stoll (2010) found that rainfed conditions decreased sugar content in Grenache but not in Syrah. In our trials, vine water status and the climatic conditions in post-veraison influenced berry sugar accumulation by the interactive effect of sugar biosynthesis and berry growth. Thus, the great mesocarp cell expansion of Bobal grapes in response to irrigation seems to delay TSS accumulation in berries due to a dilution effect, whereas irrigation caused a milder enlargement response of Tempranillo berries promoting an increase in TSS.

As we expected a different behaviour of water stress responses among cultivars, we carried out the experiment in the two $V$. vinifera varieties under different watering regimes. In Tempranillo, in fact, the reduction in TSS accumulation due to defoliation was at least in the first season less evident under rainfed conditions than under irrigation (Figure 33). It is possible that the alleviation to water stress due to defoliation compensated the reduction in the leaf area in this variety, where berry sugars accumulation was detrimentally affected by water stress (Intrigliolo et al. 2012). In Bobal, however, the reduction in grape TSS accumulation due to LLR was clear under both watering regimes. In any case, in terms of final berry composition and wine quality, the effects of LLR were in general quite similar within each watering regime, and when an interactive effect was found, this was not consistent among seasons (Tables 3 to 5). In general, when a reduction in sugar accumulation and a decrease in the acid concentration occurred in response to LLR, a similar pattern was observed in terms of berry phenolics (Figure 32 and 33). In fact, in both cultivars, the rate of phenolic accumulation during the last stage of the ripening process was not as steady as the increase in berry TTS concentration (Figures 4 and 5). Consequently, the anthocyanins-to-sugars ratio tended to be decreased by leaf removal in both trials (Table 14).

The comparison of anthocyanin and polyphenol content on a per berry basis showed that the effect of LLR on phenolic content was always detrimental. This could have occurred because LLR in general reduced the LA-to-fruit ratio, and in some cases, this ratio was decreased below the minimum thresholds $\left(0.8\right.$ and $\left.1.2 \mathrm{~m}^{2} / \mathrm{kg}\right)$ that are considered to be required for reaching proper grape ripeness (Kliewer and Dokoozlian 2005). In our trials, when the LA-to-fruit ratio was under $1.6 \mathrm{~m}^{2} / \mathrm{kg}$, the anthocyanin concentration was lower than $1 \mathrm{mg} / \mathrm{g}$. However, it should be noted that LA-to-fruit ratio is not the only physiological parameter influencing final berry phenolic concentration, as recently reported for Tempranillo grapes in a canopy management and irrigation trial (Mirás-Avalos et al. 2017). 
For instance, in 2014, when the irrigated Bobal vines reached half of the anthocyanin concentration compared to rainfed vines, the LA-to-fruit ratio was not detrimental, but the increase in berry mass lead to great skin-to-pulp ratio reductions. This played a more important role compared to the LA-to-fruit ratio, as demonstrated by the non-limiting effect of irrigation in the phenolic content when expressed on a per berry basis.

Previous studies on the effect of leaf removal or shoot trimming on sugar accumulation in the berry reported contrasting results probably due to differences in cultivar sensitivity or because of differences in the severity and timing of defoliation application. For instance, Palliotti et al. (2013a) reported that LLR applied to reduce the LAto-fruit ratio to $1.13 \mathrm{~m}^{2} / \mathrm{kg}$ did not affect phenolic composition of Sangiovese grapes, but it delayed harvest for two weeks compared to the undefoliated vines. On the other hand, Caccavello et al. (2017) found, in Aglianico grapevines, a negative impact on the wine sensory score when defoliation or shoot trimming induced reductions of LA-to-fruit ratio below $2 \mathrm{~m}^{2} / \mathrm{kg}$. This could be due to the different cultivar's response to LLR, as described by Lanari et al. (2013) for the Montepulciano and Sangiovese berry colour. Besides the intensity of defoliation, another critical aspect of the application of this technique is the timing when it is performed. Lanari et al. (2013), Palliotti et al. (2013a) and Intrieri et al. (2017) removed leaves when grape TSS was 14-17 @Brix, whereas Poni et al. (2013) and Caccavello et al. (2017) applied defoliation at around $12{ }^{\circ}$ Brix. The level of ripeness when we performed LLR was slightly lower $\left(\approx 9{ }^{\circ}\right.$ Brix), and this may have resulted detrimental for the onset of phenolic synthesis, because carbohydrate availability during the first week after the onset of veraison affects the synthesis of anthocyanin and other phenolic substances (Pirie 1977, Vitrac et al. 1999). These authors explained this effect through the role of sugars as a source of energy, but by their role as signals in the transduction pathway involved in the induction of anthocyanins biosynthesis. This is in agreement with the results of our study, as lower anthocyanin concentrations were already found at veraison in all the LLR treatments compared to that of the undefoliated vines (Figures 32G,32H, 33G and 33H), with the only exception being Tempranillo RD compared to RU vines in 2014.

Wine composition was affected by LLR because of a decrease in phenolic content and colour intensity. Therefore, the objective of higher colour-to-alcohol ratio was not achieved. However this trend was more clear in Tempranillo than in Bobal wines. The reported difference in wine hue angle among CM and WR treatments (Table 15) suggests that the different timing of ripening could also affect the type of berry pigments synthetized. This effect was reported in detail in response to LLR for Sangiovese and Cabernet Sauvignon 
grapes (Bobeica et al. 2015) and in response to drought for Tocai Friulano (Savoi et al. 2016). In our trials, LLR tended to increase the violet tones (\%blue), conversely to the rainfed effect. This might be an interesting modification as violet tones are a probable indicator of aptitude for wine ageing (Alcalde-Eon et al. 2014). These more intense purple hues are usually obtained from more mature grapes, which usually contain a higher quantity of co-pigments.

Our results highlight the complexity of the interaction between leaf area-to-fruit ratio, vine water status and the environmental conditions. Other adaptive techniques which can delay the onset of grape-ripening process without so much modifying this ratio should be tested. Among them, late pruning (Gatti et al. 2016, Moran et al. 2017) or forcing bud growth (Gu et al. 2012) appear to be very promising.

\section{Conclusions}

Late leaf removal apical to the cluster zone under regulated deficit irrigation was shown as an effective technique that can be used to delay the ripening process. However, with the subsequent delay in harvest, the composition of Bobal and Tempranillo grapes and wine was not improved. Although defoliated treatments alleviated water stress resulting in a photosynthetic-compensatory mechanism, this was insufficient to match grape phenolic composition in the same terms as the technological ripeness of the undefoliated treatments even under slightly cooler conditions. In addition, LLR constrained yield in Tempranillo vines due to reductions in cluster and berry mass. Under our experimental conditions, in a temperate-warm climate, vine water status was the main driver of grape ripening and these responses were genotype-dependent, while ambient temperature seemed to play a minor role in berry ripening. Improving our knowledge on the physiological principles underlying the response of local cultivars to canopy and water management, namely leaf area-to-fruit ratio and vine water status, will allow a better adaptation of winegrapes typicity to climate change conditions. 
Chapter V

GENERAL DISCUSSION 


\section{General discussion}

The main goal of this $\mathrm{PhD}$ thesis was the evaluation of different viticultural techniques aiming to adapt Mediterranean vineyards to climate change. The first approach was to explore the possibility of increasing grapevine water-use efficiency (WUE) to cope with future scenarios of increased water scarcity. In this regard, (Chapter II) regulated deficit irrigation, (Chapter III) vineyard row's orientation and (Chapter IV) canopy management were proposed as field practices to improve on-farm WUE. Moreover, the effects of these practices on yield components and grape composition were evaluated. Considering the importance of grape composition for wine production, this $\mathrm{PhD}$ thesis assessed viticulture adaptations to global warming by delaying grape-ripening towards cooler periods. In this sense, the effects of late leaf removal on vine performance and grape and wine composition were evaluated (Chapter IV). The effects of the studied field practices on WUE and grape composition were addressed separately from two approaches: 1) water scarcity with a focus on vine water-use and yield, and 2) warmer conditions with emphasis on grape composition. Notwithstanding, the two approaches were inevitably linked. For instance, neither the effects of yield-to-pruning ratio on grape-ripening nor the warmer conditions on vine evapotranspiration could be overlooked.

\subsection{Water scarcity adaptation}

Increasing WUE is critical for adapting grapevine performance under the scenarios of water scarcity predicted by climate change models for Mediterranean climates $(\mathrm{Xu}$ and Hsiao 2004, de Souza et al. 2005b). Possible approaches for improving vineyard WUE encompass both: the hydraulic engineering, including water collection, storage, conveyance and application; and the adequate agronomical design and management of the irrigation system (Hsiao et al. 2007). Another approach could be the cultivar selection, focusing on the genetic mechanisms underlying high WUE by exploring the adaptive phenotypic plasticity of water use traits (Nicotra and Davidson 2010, Tomás et al. 2014, Medrano et al. 2015). The present $\mathrm{PhD}$ thesis addressed the strategy of reducing vineyard water-use (evapotranspiration) by applying different field practices aimed at minimizing transpiration without affecting vine yield.

WUE was calculated as yield depending on the vineyard evapotranspiration, either estimated as irrigation + rainfall in the field experiments or measured gravimetrically as in 
the potted experiment. The increase in WUE was sought by assessing the sensitivity of vine performance in response to water restrictions applied at different phenological stages (experiment 1), by modifying the canopy radiation interception patterns through the orientation of the vineyard's rows (experiment 2), and by reducing the total vineyard radiation interception during part of the season by leaf area removal (experiment 3 ).

In experiment 1 , for the WUE estimation, the monitoring of soil water content of the full irrigated vines $\left(100 \% \mathrm{ET}_{\mathrm{c}}\right)$ was considered. In this regard, the irrigation and the precipitation that is stored in the root zone were considered for scheduling duration and frequency of irrigation events. The active root zone was estimated considering the observed root absorption in the first meter of soil depth, the portion of soil to be refilled by irrigation. We assumed that all the water applied to the crop was used. Nonetheless, it should be noted that in our trial, the water stored in the root zone was not taken into account in the WUE calculation. Thus, possible differences in its use among treatments cannot be ruled out, as the deficit irrigated vines could somehow be forced to utilize more water from the soil than the fully irrigated ones. Irrigation was usually applied at night in order to minimize the evaporation from the soil. In addition, the wet bulb was considered similar in all treatments, as the irrigation schedule was calculated weekly with the aim of applying the different water volumes by varying the frequency but not the duration of the events. Therefore, the variation in the fraction of water evaporated among irrigation treatments was considered minimal.

Experiment 1 concluded that the deficit irrigation strategy that achieved the highest WUE in Muscat of Alexandria was the sustained deficit irrigation (SDI) treatment applied at $50 \% \mathrm{ET}_{\mathrm{c}}$ throughout the entire season. Similar results were reported in most red cultivars under water restrictions (McCarthy 2000, Santos et al. 2005). Moreover, increases in WUE were reported when applying transient water deficits at phenological stages in which grape composition was also improved (McCarthy 1997, Intrigliolo and Castel 2010). It should be noted that most of the studies carried out were conducted in red wine grape varieties and there were less reports regarding the responses of white cultivars to water deficits (Chaves et al. 2007, Ortega-Farias et al. 2012). In our trial, water deficits prior to or after veraison resulted in lower WUE values than the SDI, and comparable to the efficiency of the fully irrigated treatment (Control). Regulated deficit irrigation (RDI) applied in specific phenological periods did not enhance WUE because both, early and late deficit, significantly decreased yield. This could be explained by the fact that $35 \mathrm{MPa}$ day of water stress integral was exceeded during these periods, either from anthesis to veraison or from veraison to 
harvest. The explanation for the increases in WUE due to deficit irrigation is that moderate water stress affects more the vegetative than the reproductive growth (Medrano et al. 2015, Mirás-Avalos and Intrigliolo 2017). Satisfying the potential water requirements of the vine, as in the Control treatment, increased vegetative growth and transpiration, resulting inefficient in terms of WUE. Other authors even found that full irrigation could lower yield due to reductions in bud fruitfulness or to competition with vegetative growth (Hsiao et al. 2007, Williams et al. 2010). On the other hand, the smaller leaf area developed on the vines under water deficit reduced vine water requirements. However, if a certain water stress threshold was surpassed, the beneficial effects of deficit irrigation on WUE and grape composition were no longer observed (Romero et al. 2010b, Keller et al. 2016). For instance, in the experiment 3 (late leaf removal trial), the vine water status of the rainfed treatment in Tempranillo impaired sugars biosynthesis, because the deficit irrigation application enhanced TSS in berries compared to rainfed even if deficit irrigation also stimulated berry growth. However, the positive effect of the application of irrigation on berry TSS accumulation was not observed in Bobal, although the water status of the rainfed Bobal and Tempranillo vines was comparable. Furthermore, in Bobal grapes, the anthocyanins-tosugars ratio decreased with irrigation due to increments in berry size, reducing the skin-topulp ratio in comparison to rainfed fruit. This was due to a dilution effect induced by the higher berry volume. These possible different effects of irrigation on the two Bobal and Tempranillo cultivars were already reported by Salón et al. (2004). Irrigation in Bobal detrimentally affected grape and wine quality due to the reduction of total phenolics and colour intensity, whereas in Tempranillo, irrigation increased TSS while total phenolics and the colour intensity were practically unaffected.

The low grapevine sensitivity to water deficit and quick recovery after water stress are interesting traits for climate change adaptation. However, there are differences among grapevine cultivars in their WUE in response to water stress (Cifre et al. 2005, Bota et al. 2016). For instance, de Souza et al. (2005b) reported that the intrinsic water-use efficiency $\left(W_{U} E_{i}\right)$ is characteristic of a given genotype. In this sense, the meta-analysis carried out in the literature concerning $W_{U E}$ evidences its high dependence on the genetic material and the environmental conditions (Medrano et al. 2015, Lavoie-Lamoureux et al. 2017). Our findings indirectly confirmed the low sensitivity of the carbon assimilation rates of Muscat of Alexandria under mild water stress conditions, as previously reported by other authors (Regina and Carbonneau 1996, de Souza et al. 2005a, Lavoie-Lamoureux et al. 2017). 
In experiment 2, in Bobal and Verdejo potted vines, the WUE was calculated assuming that differences in substrate moisture between water balance calculation dates were negligible. The assessment of the vineyard row's orientation on water-use, dismissing evaporation, evidenced the important role of the amount and timing of solar radiation interception on vine transpiration. Canopy interception of solar radiation, measured as the amount of shade casted on the ground, is well-known to determine water-use (Williams and Ayars 2005, López-Urrea et al. 2012, Picón-Toro et al. 2012). But its influence on the photosynthetic capacity is also recognized (Poni et al. 2003, Baeza et al. 2005, Buckley and Mott 2013). For these reasons, the WUE as a function of the intercepted solar radiation is a complex issue that influenced by many physiological factors. In our trial, the reductions in water-use per unit of leaf area found in the in EW compared to NS were consistent with the PAR interception simulations modelled in response to these two vineyard row's orientations (Campos et al. 2017). This was because, in the absence of vine water stress, water-use was linearly related to radiation interception (Williams and Ayars 2005). Nevertheless, the time of day when solar radiation was intercepted determined the environmental factors influencing the relationship between water-use and radiation interception, i.e. vapour pressure deficit (VPD) or the PAR portion of total radiation and, consequently, canopy temperature. Additionally, other factors such as the nutritional status of the crop may influence the radiation use efficiency, which is linked to WUE overall (Steduto and Albrizio 2005).

Water productivity in Experiment 2, defined as WUE, tended to be increased by the EW row orientation because yield was not clearly affected in comparison to that of the NS. This is an experimental evidence of the conservative behaviour of the efficiency in wateruse by crops to produce biomass (Steduto et al. 2007). The theoretical background of this is depicted in Figure 35. In general terms, the canopy interception of solar radiation determines both carbon assimilation and transpiration by the plant. Both photosynthesis and transpiration are also modulated by the physical gradient in $\left[\mathrm{CO}_{2}\right]$ and $\left[\mathrm{H}_{2} \mathrm{O}\right]$ between the leaf intercellular air space and the atmosphere. Thus, the possible differences in $\left[\mathrm{H}_{2} \mathrm{O}\right]$ induced by the vineyard row's orientation in the boundary layer of leaves may have influenced the stomatal resistances and, consequently, the gas exchange $\left(\mathrm{CO}_{2}\right.$ and $\left.\mathrm{H}_{2} \mathrm{O}\right)$. Similarly, in both cultivars, lower air humidity during the afternoon may have decreased the physiological performance of the vine at this time of day. Particularly, the lower transpiration rates we observed at the leaf level in the EW vines during the afternoon compared to that of the NS ones, could be pointing to shifts in the assimilation-to- 
transpiration ratio ( $\mathrm{Xu}$ and Hsiao 2004). Nonetheless, in Bobal, total dry matter was increased in the NS, but not yield. It is worth noting that the possible influence of vine radiation load will affect the thermal distribution within the canopy between the treatments in different ways, affecting transpiration but also respiration, and thus carbon assimilation efficiency (Amthor 1989, Ryan 1991). This begs the question of the effects of row orientation on WUE on vineyards under water stress. Since in our trial the vine water status showed no stress, with minor differences in response to the row's orientation in both cultivars.
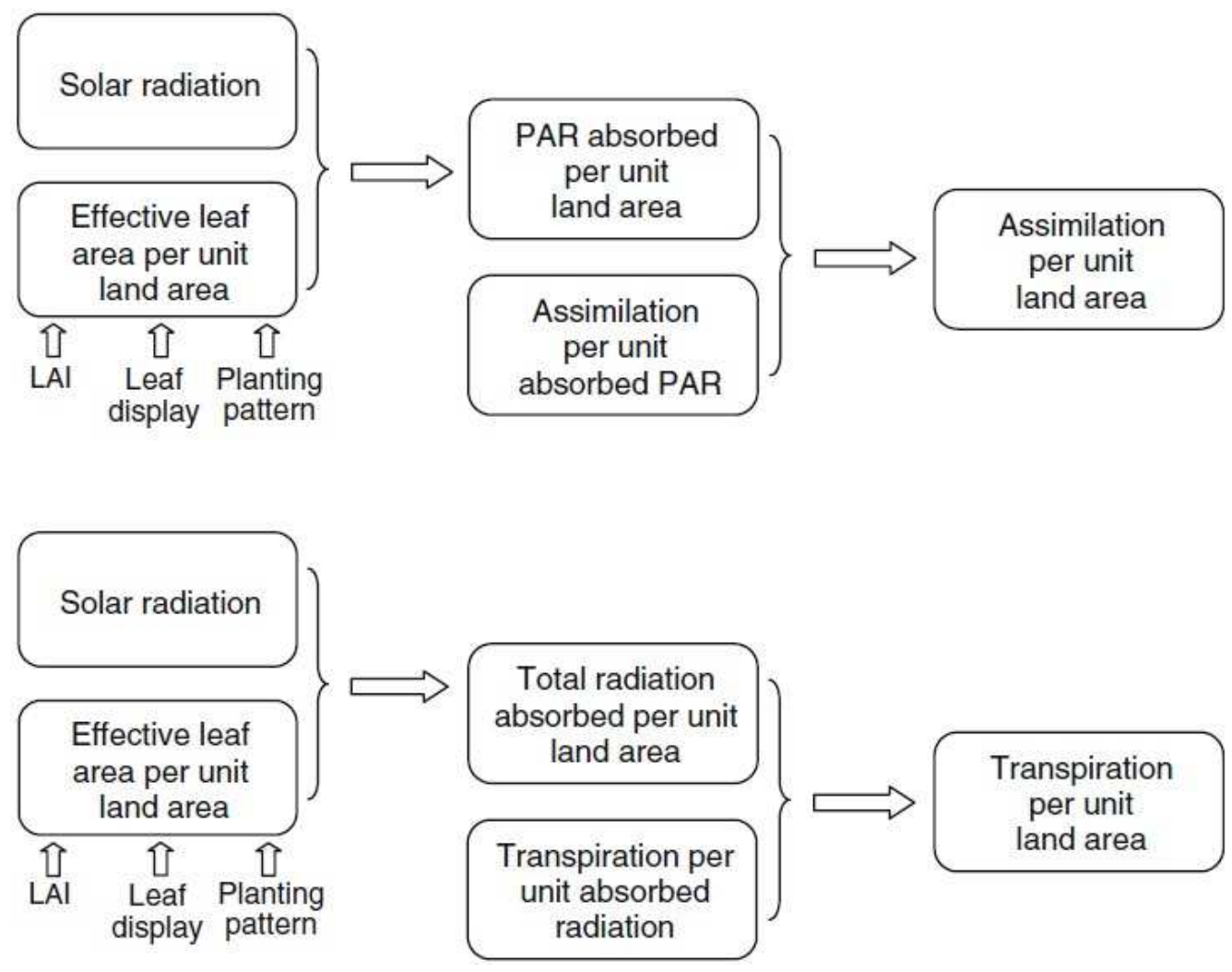

Figure 35. Factors affecting assimilation and transpiration of canopies. Arrows indicate casual relations. All considerations are on a land area basis. Modified from Steduto et al. (2007).

In experiment 3, vine water stress was alleviated by the late leaf removal (LLR) under both water regimes and cultivars. This is supposed to be attributable to the reduction of the potential transpiration despite the compensatory behaviour found in the remaining leaves. However, at least in Tempranillo, LLR did not lead to increments in WUE because in both seasons yield was significantly lessened by LLR. In Bobal, although no effects on carbon assimilation in terms of yield were found due to the leaf area reduction, no positive LLR carry-over effects on yield were detected due to the presumed increased availability of water. 
In summary, the application of RDI strategies seems to be an interesting technique to face water scarcity, especially in high value crops such as winegrapes. Field RDI experiments such as Experiment 1 of the present work provides the scientific knowledge needed to avoid too severe water stress when it is undesirable. In this regard, a system for continuous and automatic water status monitoring would be required (Fereres et al. 2003). Alternative indicators of plant water stress, such as remote sensing techniques or multiple sensors, could be used and could be integrated into a decision-making system (Ginestar et al. 1998, Zarco-Tejada et al. 2005, Intrigliolo and Castel 2006, Intrigliolo and Castel 2007, Jiménez-Bello et al. 2011, McClymont et al. 2012, Costa et al. 2016, Diago et al. 2018). Nonetheless, in the predicted future scenarios of less water availability and of higher salinity, the risks of soil salinization and loss of soil structure have to be considered. Moreover, designing the vineyard row's orientation towards the east-west direction instead of the most common north-south direction, can reduce daily vineyard radiation load and can be effective in reducing vine water requirements. Therefore, the last two studies (experiments 1 and 2) could result interesting for adapting Mediterranean viticulture to climate change, as the Mediterranean-like climate is characterized by being water-limited for an adequate vine development rather than solar radiation-limited. In addition, the deficit irrigation technique will significantly reduce production costs by reducing water pumping for irrigation. On the other hand, the LLR technique carried out in cvs. Bobal and Tempranillo could negatively impact the winegrowers' revenues. This is because LLR, in spite of improving vine water status, did not improve WUE. As a matter of fact, the experiment related to LLR was designed with the objective of improving red grape and wine composition rather than for increasing WUE.

\subsection{Warmer conditions adaptation}

The evaluation of the effectiveness of the proposed field practices is addressed from the perspective of berry composition as the result of vine conditions during ripening. The possible changes in cluster micro-climate conditions induced by treatments were not measured. Neither solar radiation interception nor temperature evolution were recorded in the cluster zone. The assessment was carried out through the comparison among the treatments imposed in each experiment, integrating all the vine responses on grape composition. The discussion is focused on sugars and organic acid content (primary metabolites), and in polyphenols, namely anthocyanins (secondary metabolites). All of 
these essential compounds for wine quality were evaluated by analysing the balanced ratio between them. This includes: i) the total soluble solids-to-total acidity (TSS-to-TA) ratio, because acidity equilibrates sweetness and it is related to organoleptic perception, and ii) the anthocyanins-to-sugars ratio because anthocyanin influence colour and wine mouthfeel and astringency. In addition, the acid content determines wine $\mathrm{pH}$, which is a crucial parameter for wine microbial stability (Boulton 1980). High pH is one of the undesired effects associated with climate change in Mediterranean-like climates (Salazar-Parra et al. 2010). Another adverse effect is the decoupling of anthocyanins and sugar biosynthesis due to global warming (Sadras and Moran 2012, Palliotti et al. 2014).

In experiment 1, our goal for the application of RDI in Muscat of Alexandria was to improve grape composition in terms of balanced TSS-to-TA ratio. Early deficit (ED) accelerated grape-ripening, increasing TSS and reducing malic acid, most likely due to an increase in malic catabolism because of the higher cluster exposure. Whereas late deficit (LD) did not modify much the berry composition in comparison to the fully-irrigated treatment (Control). These results evidenced that the high yields of the Control treatment did not have to be necessarily related to deficient grape composition for wine making purposes, since the Control grapes did not show an unbalanced TSS-to-TA ratio. Nonetheless, the most favourable grapes for wine-making were those obtained from the sustained deficit irrigation strategy (SDI), which increased TSS compared to the Control treatment without reducing must $\mathrm{pH}$. This was because despite the reduction of malic acid concentration, this acid is weaker than the tartaric one. In turn, SDI should result in the highest grape prices and the lowest irrigation costs.

The main goal of the experiment 2 was to assess vine WUE rather than grape composition, because we considered that the conclusions obtained from potted vines may not be to be extrapolated to field conditions. Indeed, the effects of vineyards rows' orientation on grape composition at harvest were not consistent among seasons and cultivars. This may be because row orientation did not affect the cluster microclimate differently, as it is well known that sunlight exposure affects berry composition (Smart 1985, Spayd et al. 2002, Pereira et al. 2006). In 2015, the Bobal grapes from EW did not reach the maturity level of grapes from NS because the LA-to-yield ratio was in both orientations, below the threshold values cited in the literature for reaching full ripening (Kliewer and Dokoozlian 2005). That season, Bobal grapes from the EW rows had lower TSS and total phenolics than the ones from NS. This reveals that when the vegetative-to-crop load ratio is low, the lower PAR intercepted by EW row orientation did induce significant 
grape-ripening delays as compared to NS. Grape phenolic composition is also affected by the skin-to-pulp ratio because some of the grape polyphenols are found in skin tissues. In the Verdejo cultivar, the skin-to-pulp ratio was significantly decreased in all seasons in response to the EW orientation compared to NS. In Bobal a similar effect was only found in the first season. A decrease in the skin-to-pulp ratio in response to EW vineyards row's orientation was already observed in Shiraz by Hunter et al. (2017), and can have an important negative effect for oenological purposes due to the dilution effect of phenolic and aromatic compounds in wine.

In experiment 3 , the main goal was to couple the anthocyanins-to-sugars ratio by delaying berry-ripening and thus favouring thermal conditions for pigments accumulation. In this regard, reducing the leaf area-to-fruit ratio by applying apical defoliation at the beginning of ripening was effective in slowing down grape-ripening rates in both Bobal and Tempranillo cvs. This is because of the high contribution to the vine's carbon assimilation of the young-mature leaves removed (Poni et al. 1994). However, in the LLR treatments the consequent postponement of the harvest date did not lead to an increase in the anthocyanins-to-sugars ratio compared to the grapes from undefoliated vines. Even when the effect of LLR on the skin-to-pulp ratio was to increase it, the grapes of LLR did not result in higher anthocyanin content in comparison to the grapes from the undefoliated vines. Under our conditions, LLR proved ineffective for coupling technological and phenolic maturity, in contrast to previous reports (Palliotti et al. 2013a, Poni et al. 2013, Intrieri et al. 2017). The sensitivity of the anthocyanins from this genotype to high air temperature indeed can be different (Fernandes de Oliveira et al. 2015) and therefore, the graperipening's response to thermal differences resulting from LLR can also vary among cultivars (Lanari et al. 2013). In addition, Bobeica et al. (2015) reported that source limitation (leaves) affected anthocyanin profiles in a cultivar-dependent manner. Therefore, for the adaptation to global warming of Bobal and Tempranillo grapes, we suggested that considerably shifting forward the onset of ripening without reducing the LA-to-yield ratio may improve grape composition rather than slowing down grape-ripening. Because, as Sadras and Moran (2012) explained, the disruption in the anthocyanins-to-sugars ratio in berries at high temperature was due to the delayed onset of anthocyanins accumulation rather than the rate of anthocyanins accumulation.

This $\mathrm{PhD}$ thesis studied several field practices for adapting Mediterranean viticulture to climate change affecting many vineyard relations that requires careful forethought before applying them to a specific terroir. In our conditions, RDI strategies and 
vineyard row's orientation improved WUE, but LLR failed to couple anthocyanins and sugars in berries. Under the predicted scenarios of climate change, water management can help to improve WUE in addition to modulating grape composition. Moreover, irrigation practices and canopy architecture design can mitigate cluster heat stress in vines suffering water-stress. In this sense promoting the association of grapevines with arbuscular mycorrhizal fungi could contribute to optimize the effects of irrigation strategies on berry properties under future warming conditions (Biricolti et al. 1997, Schreiner 2003, Aguín et al. 2004, Torres et al. 2017). Besides, other practices that can enhance soil water holding capacity and/or minimizes soil evaporation, such as increasing soil organic matter and/or mulch application, may be effective for coping with the predicted water scarcity (LópezUrrea et al. 2016). In this regard, techniques aiming at regulating canopy temperature during grape-ripening such as shading nets, sprinkler cooling systems utilization and particle films application can also be effective in reducing water and heat stress (Rosati 2007, Caravia et al. 2016, 2017, Paciello et al. 2017). Another adaptation strategy could be to delay vine phenology through field practices such as late pruning (Frioni et al. 2016, Gatti and Poni 2018) or forcing bud growth (Gu et al. 2012). Of particular interest indeed would be the assessment of vine water-use when viticultural practices significantly shift vine phenology timing back to periods with cooler conditions. Even more combined with practices such as leaning canopies or EW vineyard row's orientation, because most of the vine development will take place distant to the summer solstice. In this period, the angle of sunlight incidence is less perpendicular to the Earth's surface, and thus vineyard radiation interception pattern will be modified. Moreover, shifting the growing season to periods of the summer under lower evapotranspiration demand can reduce water-use, as it was already reported for other crops (Fereres et al. 1993, Xu and Hsiao 2004). Nevertheless, the possible carry-over effects of these techniques on reserves replenishment due to the shortening of the post-harvest period should be taken into account (Ferreyra et al. 2003, Lebon et al. 2008).

If the increase in the warmer future climate conditions does not stop, techniques such as LLR might result effective for Mediterranean adaptation to climate change ones the thermal threshold above which anthocyanin biosynthesis is limited is exceeded. On the other hand, the improvement in WUE resulting from the RDI strategies or from the modification of vineyard row's orientation may be insufficient for facing significant changes in water availability. Ultimately, there are biophysical and economic limits for adaptation. Under the scenario of climate change, the extraordinarily-diverse biological and cultural 
heritage that we treasure in our vineyards is threatened. But in this sense, grape growing is just one of all possible ecological impacts... 
Chapter VI

GENERAL CONCLUSIONS 


\section{General conclusions}

The results obtained from the three experiments carried out in the present $\mathrm{PhD}$ thesis resulted in the following conclusions:

\section{Techniques for adapting to water scarcity}

1. Field practices such as deficit irrigation or canopy management can be used for adapting Mediterranean viticulture to the climate change conditions of increasing water scarcity.

2. An adequate vine water status in Muscat of Alexandria is guaranteed if the water stress integral threshold value of $35 \mathrm{MPa}$ day is not surpassed neither between the periods from anthesis to veraison, or from veraison to harvest.

3. Sustained Deficit Irrigation (SDI) at $50 \%$ of the estimated crop evapotranspiration $\left(\mathrm{ET}_{\mathrm{c}}\right)$ improved water-use efficiency (WUE), ensuring the high yield potential of Muscat of Alexandria while enhancing grape sugar accumulation. This strategy allowed water savings of $48 \%$ compared to full irrigation (100\% ETc). We are confident to recommend the SDI strategy to winegrowers when water is scarce or expensive. Caution should be paid if water withholding has to be continued for more than three seasons because of the possible detrimental carry over effects on vine performance.

4. Pre-veraison water shortage (ED) reduced yield by $25 \%$ due to lower berry mass and shoot fruitfulness in comparison to that of fully irrigated (100\% $\left.\mathrm{ET}_{\mathrm{c}}\right)$. ED advanced grape-ripening by increasing TSS and reducing malic acid. In the threeyear study, this strategy allowed water savings of up to $40 \%$ compared to full irrigation.

5. Post-veraison water deficit (LD) reduced yield by $15 \%$ in comparison to that of fully irrigated $\left(100 \% \mathrm{ET}_{\mathrm{c}}\right)$ with little change in berry composition and resulted in water savings of $29 \%$. 
6. Vine transpiration can be reduced by orienting the vineyard's rows east-west (EW) instead of north-south (NS). The water-use reduction achieved in vines under no water stress were 13\% for Bobal and 7\% for Verdejo, corresponding, for both cultivars to an $18 \%$ water-use reduction relative to total leaf area.

7. In fully irrigated potted-vines, EW vineyard row orientation resulted in WUE increases of $26 \%$ for Bobal and 19\% for Verdejo compared to NS, with little or no consistent changes in grape composition. These results encourage the carrying out of field studies before recommending winegrowers to orient the vineyard rows EW instead of NS aiming at the adaptation of Mediterranean viticulture to water scarcity.

8. Late leaf removal (LLR) alleviated water stress and triggered a physiological compensatory mechanism. However, in Tempranillo, this was insufficient for matching the yields of the undefoliated treatments due to reductions in cluster and berry mass.

\section{Field practices for adapting to warmer conditions}

9. LLR apical to the cluster zone of approximately $25 \%$ of LA was shown to be effective for slowing down ripening rates in Bobal and Tempranillo, postponing graperipening towards relatively cooler periods. Nonetheless, LLR did not result beneficial for coupling technological and phenolic maturity in red grapes, and even hindered complete ripening in Bobal. Under a Mediterranean-like climate, the effectiveness of the LLR technique seems to depend on its final impacts to the LAto-fruit ratio and vine water status rather than on the environmental conditions.

10. Under low vigour vine conditions, LLR tended to decrease red wine colour intensity and increase the hue angle in both cultivars. Wines made with grapes from rainfed vines had a tendency to improve wine anthocyanin concentration and TPI as compared to that from deficit-irrigated vines.

11. Severe LLR is therefore not recommended under the conditions of the present experiments and we suggest further studies in order to identify other suitable techniques for improving grape composition. 


\section{References}

Aguín, O., J. P. Mansilla, A. Vilariño and M. J. Sainz (2004). Effects of mycorrhizal inoculation on root morphology and nursery production of three grapevine rootstocks. American Journal of Enology and Viticulture 55(1): 108-111.

Ainsworth, E. A. and A. Rogers (2007). The response of photosynthesis and stomatal conductance to rising [CO2]: mechanisms and environmental interactions. Plant, cell \& environment 30(3): 258-270.

Alcalde-Eon, C., I. García-Estévez, R. Ferreras-Charro, J. C. Rivas-Gonzalo, R. FerrerGallego and M. T. Escribano-Bailón (2014). Adding oenological tannin vs. overripe grapes: Effect on the phenolic composition of red wines. Journal of Food Composition and Analysis 34(1): 99-113.

Allen, R. G., L. S. Pereira, D. Raes and M. Smith (1998). Crop evapotranspirationGuidelines for computing crop water requirements-FAO Irrigation and drainage paper 56. FAO, Rome 300(9): D05109.

Amerine, M. A. and A. J. Winkler (1944). Composition and quality of musts and wines of California grapes. Hilgardia 15: 493-675.

Amthor, J. S. (1989). Respiration and crop productivity. Physiology of respiration. . Springer Verlag, New York, USA: 44-68 pp.

Anderson, J., F. Chung, M. Anderson, L. Brekke, D. Easton, M. Ejeta, R. Peterson and R. Snyder (2008a). Progress on incorporating climate change into management of California's water resources. Climatic Change 87(1): 91-108.

Anderson, K., C. Findlay, S. Fuentes and S. Tyerman (2008b). Viticulture, wine and climate change. Commissioned Paper for the Garnaut Climate Change Review.

Baeza, P., C. Ruiz, E. Cuevas, V. Sotés and J.-R. Lissarrague (2005). Ecophysiological and Agronomic Response of Tempranillo Grapevines to Four Training Systems. American Journal of Enology and Viticulture 56(2): 129-138.

Baeza, P., P. Sánchez-de-Miguel, A. Centeno, P. Junquera, R. Linares and J. R. Lissarrague (2007). Water relations between leaf water potential, photosynthesis and agronomic vine response as a tool for establishing thresholds in irrigation scheduling. Scientia Horticulturae 114(3): 151-158.

Baeza, P., P. Sánchez-De-Miguel and J. R. Lissarrague (2010). Radiation Balance in Vineyards. Methodologies and Results in Grapevine Research. S. Delrot, H. Medrano, E. Or, L. Bavaresco and S. Grando. Dordrecht, Springer Netherlands: 21-29. 
Baggiolini, M. (1952). Les stades repères dans le développement de la vigne et leur utilisation pratique, Station Féd. Essais Agric., Lausanne.

Bartsch, N. (1987). Responses of root systems of young Pinussylvestris and Piceaabies plants to water deficits and soil acidity. Canadian Journal of Forest Research 17(8): 805-812.

Basile, B., G. Caccavello, M. Giaccone and M. Forlani (2015). Effects of Early Shading and Defoliation on Bunch Compactness, Yield Components, and Berry Composition of Aglianico Grapevines under Warm Climate Conditions. American Journal of Enology and Viticulture.

Bates, T. (2008). Pruning Level Affects Growth and Yield of New York Concord on Two Training Systems. American Journal of Enology and Viticulture 59(3): 276-286.

Batjes, N. H. (1996). Total carbon and nitrogen in the soils of the world. European Journal of Soil Science 47(2): 151-163.

Bautista-Nazrala, J. J. (2007). Microclima de la canopia de la vid: influencia del manejo del suelo y coberturas vegetales. Revista de la Facultad de Ciencias Agrarias [on line] http://www.redalyc.org/articulo.oa?id=382837654001(ISSN 0370-4661).

Belancic, A., E. Agosin, A. Ibacache, E. Bordeu, R. Baumes, A. Razungles and C. Bayonove (1997). Influence of Sun Exposure on the Aromatic Composition of Chilean Muscat Grape Cultivars Moscatel de Alejandría and Moscatel rosada. American Journal of Enology and Viticulture 48(2): 181-186.

Bergqvist, J., N. Dokoozlian and N. Ebisuda (2001). Sunlight exposure and temperature effects on berry growth and composition of Cabernet Sauvignon and Grenache in the Central San Joaquin valley of California. American Journal of Enology and Viticulture 52(1): 1-7.

Bernizzoni, F., Gatti, M., Civardi, S. and Poni, S. (2009). Long-term Performance of Barbera Grown under Different Training Systems and Within-Row Vine Spacings. American Journal of Enology and Viticulture 60(3): 339-348.

Berry, J. and 0. Bjorkman (1980). Photosynthetic response and adaptation to temperature in higher plants. Annual Review of Plant Physiology 31(1): 491-543.

Betts, R. A., O. Boucher, M. Collins, P. M. Cox, P. D. Falloon, N. Gedney, D. L. Hemming, C. Huntingford, C. D. Jones and D. M. Sexton (2007). Projected increase in continental runoff due to plant responses to increasing carbon dioxide. Nature 448(7157): 1037. 
Bindi, M., L. Fibbi, B. Gozzini, S. Orlandini and F. Miglietta (1996). Modelling the impact of future climate scenarios on yield and yield variability of grapevine. Climate Research 7(3): 213-224.

Bindi, M., L. Fibbi and F. Miglietta (2001). Free Air CO2 Enrichment (FACE) of grapevine (Vitis vinifera L.): II. Growth and quality of grape and wine in response to elevated CO2 concentrations. European Journal of Agronomy 14(2): 145-155.

Biricolti, S., F. Ferrini, E. Rinaldelli, I. Tamantini and N. Vignozzi (1997). VAM Fungi and Soil Lime Content Influence Rootstock Growth and Nutrient Content. American Journal of Enology and Viticulture 48(1): 93-99.

Bladé, I., B. Liebmann, D. Fortuny and G. J. van Oldenborgh (2012). Observed and simulated impacts of the summer NAO in Europe: implications for projected drying in the Mediterranean region. Climate Dynamics 39(3): 709-727.

Bloom, A. J., M. Burger, J. S. R. Asensio and A. B. Cousins (2010). Carbon Dioxide Enrichment Inhibits Nitrate Assimilation in Wheat and Arabidopsis. Science 328(5980): 899-903.

Bobeica, N., S. Poni, G. Hilbert, C. Renaud, E. Gomès, S. Delrot and Z. Dai (2015). Differential responses of sugar, organic acids and anthocyanins to source-sink modulation in Cabernet Sauvignon and Sangiovese grapevines. Frontiers in plant science 6: 382.

Bonada, M., V. O. Sadras and S. Fuentes (2013). Effects of elevated temperature on mesocarp cell death and shrivelling in Shiraz and Chardonnay berries. Australian \& New Zealand Grapegrower and Winemaker February(589): 35-36.

Bondada, B., J. I. Covarrubias, P. Tessarin, A. C. Boliani, G. Marodin and A. D. Rombolà (2016). Postveraison Shoot Trimming Reduces Cluster Compactness without Compromising Fruit Quality Attributes in Organically-Grown Sangiovese Grapevines. American Journal of Enology and Viticulture: ajev. 2016.15058.

Bota, B. J., J. Flexas and H. Medrano (2001). Genetic variability of photosynthesis and water use in Balearic grapevine cultivars. Annals of Applied Biology 138(3): 353-361.

Bota, J., M. Tomás, J. Flexas, H. Medrano and J. M. Escalona (2016). Differences among grapevine cultivars in their stomatal behavior and water use efficiency under progressive water stress. Agricultural Water Management 164(Part 1): 91-99.

Bouard, J. (1967). Influence de l'époque de la taille sur la production des raisins. Comptes rendus des Séances de l'Académie d'Agriculture de France 53: 639-644. 
Boucher, O., A. Jones and R. A. Betts (2009). Climate response to the physiological impact of carbon dioxide on plants in the Met Office Unified Model HadCM3. Climate Dynamics 32(2-3): 237-249.

Boulton, R. (1980). The relationships between total acidity, titratable acidity and pH in grape tissue. Vitis 19(2): 113-120.

Bradshaw, A. D. (1965). Evolutionary significance of phenotypic plasticity in plants. Advances in Genetics 13: 115-155.

Bradshaw, A. D. (2006). Unravelling phenotypic plasticity-why should we bother? New Phytologist 170(4): 644-648.

Bravdo, B., Y. Hepner, C. Loinger, S. Cohen and H. Tabacman (1985). Effect of Irrigation and Crop Level on Growth, Yield and Wine Quality of Cabernet Sauvignon. American Journal of Enology and Viticulture 36(2): 132-139.

Brunetti, M., L. Buffoni, F. Mangianti, M. Maugeri and T. Nanni (2004). Temperature, precipitation and extreme events during the last century in Italy. Global and Planetary Change 40(1): 141-149.

Buck, A. L. (1981). New equations for computing vapor pressure and enhancement factor. Journal of Applied Meteorology 20(12): 1527-1532.

Buckley, T. N., A. Cescatti and G. D. Farquhar (2013). What does optimization theory actually predict about crown profiles of photosynthetic capacity when models incorporate greater realism? Plant, Cell \& Environment 36(8): 1547-1563.

Buckley, T. N. and K. A. Mott (2013). Modelling stomatal conductance in response to environmental factors. Plant, Cell \& Environment 36(9): 1691-1699.

Buttrose, M. S. and C. R. Hale (1973). Effect of temperature on development of the grapevine inflorescence after bud burst. American Journal of Enology and Viticulture 24(1): $14-16$.

Buttrose, M. S., C. R. Hale and W. M. Kliewer (1971). Effect of temperature on the composition of 'Cabernet Sauvignon' berries. American Journal of Enology and Viticulture 22(2): 71-75.

Caccavello, G., M. Giaccone, P. Scognamiglio, M. Forlani and B. Basile (2017). Influence of intensity of post-veraison defoliation or shoot trimming on vine physiology, yield components, berry and wine composition in Aglianico grapevines. Australian Journal of Grape and Wine Research 23(2): 226-239. 
Campos, I., C. M. U. Neale and A. Calera (2017). Is row orientation a determinant factor for radiation interception in row vineyards? Australian Journal of Grape and Wine Research 23(1): 77-86.

Camps, J. O. and M. C. Ramos (2012). Grape harvest and yield responses to interannual changes in temperature and precipitation in an area of north-east Spain with a Mediterranean climate. International Journal of Biometeorology 56(5): 853-864.

Cancela, J. J., E. Trigo-Córdoba, E. M. Martínez, B. J. Rey, Y. Bouzas-Cid, M. Fandiño and J. M. Mirás-Avalos (2016). Effects of climate variability on irrigation scheduling in white varieties of Vitis vinifera (L.) of NW Spain. Agricultural Water Management 170: 99-109.

Caravia, L., C. Collins, P. R. Petrie and S. Tyerman (2016). Application of shade treatments during Shiraz berry ripening to reduce the impact of high temperature. Australian Journal of Grape and Wine Research 22(3): 422-437.

Caravia, L., V. Pagay, C. Collins and S. Tyerman (2017). Application of sprinkler cooling within the bunch zone during ripening of Cabernet Sauvignon berries to reduce the impact of high temperature. Australian Journal of Grape and Wine Research 23(1): 48-57.

Carbonneau, A. and Casteran, P. (1987). Optimization of vine performance by the lyre training system. Proceedings of the Sixth Australian Wine Industry Technical Conference. T. Lee (Ed.).

Carbonneau, A. (2009). Evolution of canopy management: from history to scientific modelling. Proceedings of Recent Advances in Grapevine Canopy Management, July 16: 2742.

Castel, J. R., M. E. Valdés, M. H. Prieto, D. Uriarte, L. Mancha, A. Montoro, F. Mañas, R. López-Urrea, P. López-Fuster and J. Yuste (2012). Terroir effects on the response of Tempranillo grapevines to irrigation in four locations of Spain: agronomic performance and water relations. IXe International Terroirs Congress.

Castellarin, S. D., M. A. Matthews, G. d. Gaspero and G. A. Gambetta (2007a). Water deficits accelerate ripening and induce changes in gene expression regulating flavonoid biosynthesis in grape berries. Planta 227(1): 101-112.

Castellarin, S. D., A. Pfeiffer, P. Sivilotti, M. Degan, E. Peterlunger and G. Di Gaspero (2007b). Transcriptional regulation of anthocyanin biosynthesis in ripening fruits of grapevine under seasonal water deficit. Plant Cell and Environment 30(11): 1381-1399. 
Centinari, M., Poni, S., Intrigliolo, D. S., Dragoni, D. and Lakso, A. N. (2012). Cover crop evapotranspiration in a northeastern US Concord (Vitis labruscana) vineyard. Australian Journal of Grape and Wine Research 18(1): 73-79.

Centinari, M., I. Filippetti, T. Bauerle, G. Allegro, G. Valentini and S. Poni (2013). Cover Crop Water Use in Relation to Vineyard Floor Management Practices. American Journal of Enology and Viticulture 64(4): 522-526.

Chaouche, K., L. Neppel, C. Dieulin, N. Pujol, B. Ladouche, E. Martin, D. Salas and Y. Caballero (2010). Analyses of precipitation, temperature and evapotranspiration in a French Mediterranean region in the context of climate change. Comptes Rendus Geoscience 342(3): 234-243.

Chapman, D. M., G. Roby, S. E. Ebeler, J.-X. Guinard and M. A. Matthews (2005). Sensory attributes of Cabernet Sauvignon wines made from vines with different water status. Australian Journal of Grape and Wine Research 11(3): 339-347.

Chaves, M.M. 1986. Fotosíntese e repartiçao dos produtos de assimileçâo en Vitis vinifera L. Ph.D. thesis, Lisbon University, Instituto Técnico Superior de Agronomía.

Chaves, M. M., J. Flexas and C. Pinheiro (2009). Photosynthesis under drought and salt stress: regulation mechanisms from whole plant to cell. Annals of Botany 103(4): 551560.

Chaves, M. M., T. P. Santos, C. R. Souza, M. F. Ortuno, M. L. Rodrigues, C. M. Lopes, J. P. Maroco and J. S. Pereira (2007). Deficit irrigation in grapevine improves water-use efficiency while controlling vigour and production quality. Annals of Applied Biology 150(2): 237-252.

Chen, W.-K., X.-J. Bai, M.-M. Cao, G. Cheng, X.-J. Cao, R.-R. Guo, Y. Wang, L. He, X.-H. Yang, F. He, C.-Q. Duan and J. Wang (2017). Dissecting the Variations of Ripening Progression and Flavonoid Metabolism in Grape Berries Grown under Double Cropping System. Frontiers in plant science 8(1912).

Chomé Fuster, P., V. Sotés Ruiz, F. Benayas y Sainz de Rozas, M. Cayuela González, M. Hernández Sánchez, F. Sáenz de Santa María, J. Ortiz Marcide, I. Rodríguez Torres and J. Chaves Rabanal (2003). Grapevine varieties: registration of commercial varieties.

Choné, X., C. Van Leeuwen, D. Dubourdieu and J. P. Gaudillère (2001). Stem Water Potential is a Sensitive Indicator of Grapevine Water Status. Annals of Botany 87(4): 477483. 
Cifre, J., J. Bota, J. Escalona, H. Medrano and J. Flexas (2005). Physiological tools for irrigation scheduling in grapevine (Vitis vinifera L.): An open gate to improve water-use efficiency? Agriculture, Ecosystems \& Environment 106(2): 159-170.

Clingeleffer, P. R. and D. R. Emmanuelli (2006). An assessment of rootstocks for Sunmuscat (Vitis vinifera L.): a new drying variety. Australian Journal of Grape and Wine Research 12(2): 135-140.

Coipel, J., B. Rodriguez-Lovelle, C. Sipp and C. Van Leeuwen (2006). "Terroir" effect, as a result of environmental stress, depends more on soil depth than on soil type (Vitis vinifera L. cv. Grenache noir, Côtes du Rhône, France, 2000). Journal International des Sciences de la Vigne et du Vin 40(4): 177-185.

Coll, P., E. Le Cadre, E. Blanchart, P. Hinsinger and C. Villenave (2011). Organic viticulture and soil quality: A long-term study in Southern France. Applied Soil Ecology 50: $37-44$.

Comas, L. H., T. L. Bauerle and D. M. Eissenstat (2010). Biological and environmental factors controlling root dynamics and function: effects of root ageing and soil moisture. Australian Journal of Grape and Wine Research 16: 131-137.

Coniberti, A., V. Ferrari, E. Dellacassa, E. Boido, F. Carrau, V. Gepp and E. Disegna (2013). Kaolin over sun-exposed fruit affects berry temperature, must composition and wine sensory attributes of Sauvignon blanc. European Journal of Agronomy 50(0): 75-81.

Connor, J. D., K. Schwabe, D. King and K. Knapp (2012). Irrigated agriculture and climate change: The influence of water supply variability and salinity on adaptation. Ecological Economics 77: 149-157.

Cook, B. I. and E. M. Wolkovich (2016). Climate change decouples drought from early wine grape harvests in France. Nature Climate Change 6(7): 715.

Coombe, B. (1987). Influence of temperature on composition and quality of grapes. Symposium on Grapevine Canopy and Vigor Management, XXII IHC 206.

Coombe, B. G. (1959). Fruit Set and Development in Seeded Grape Varieties as Affected by Defoliation, Topping, Girdling, and Other Treatments. American Journal of Enology and Viticulture 10(2): 85-100.

Correia, C. M., L. T. Dinis, H. Fraga, R. Pinheiro, H. M. Ferreira, J. Costa, I. Gonçalves, A. A. Oliveira, G. Pinto, J. A. Santos, A. C. Malheiro and J. M. Moutinho-Pereira (2015). Enhanced 
Yield and Physiological Performance of Mediterranean Grapevines through Foliar Kaolin Spray. Procedia Environmental Sciences 29: 247-248.

Costa, J. M., M. Vaz, J. Escalona, R. Egipto, C. Lopes, H. Medrano and M. M. Chaves (2016). Modern viticulture in southern Europe: Vulnerabilities and strategies for adaptation to water scarcity. Agricultural Water Management 164: 5-18.

Cramer, G. R., A. Ergul, J. Grimplet, R. L. Tillett, E. A. Tattersall, M. C. Bohlman, D. Vincent, J. Sonderegger, J. Evans and C. Osborne (2007). Water and salinity stress in grapevines: early and late changes in transcript and metabolite profiles. Funct Integr Genomics 7.

Cuevas, E., P. Baeza and J. R. Lissarrague (2006). Variation in stomatal behaviour and gas exchange between mid-morning and mid-afternoon of north-south oriented grapevines (Vitis vinifera L. cv. Tempranillo) at different levels of soil water availability. Scientia Horticulturae 108(2): 173-180.

Dai, A. (2011). Drought under global warming: a review. Climate Change 2(1): 45-65.

Dai, Z. W., N. Ollat, E. Gomes, S. Decroocq, J.-P. Tandonnet, L. Bordenave, P. Pieri, G. Hilbert, C. Kappel, C. van Leeuwen, P. Vivin and S. Delrot (2011). Ecophysiological, genetic, and molecular causes of variation in grape berry weight and composition: a review. American Journal of Enology and Viticulture 62(4): 413-425.

de Cortázar, V. G., C. Córdova and M. Pinto (2005). Canopy structure and photosynthesis modelling of grapevines (Vitis vinifera L. cv. Sultana) grown on an overhead (parronal) trellis system in Chile. Australian Journal of Grape and Wine Research 11(3): 328338.

de Souza, C. R., J. P. Maroco, T. P. dos Santos, M. L. Rodrigues, C. Lopes, J. S. Pereira and M. M. Chaves (2005a). Control of stomatal aperture and carbon uptake by deficit irrigation in two grapevine cultivars. Agriculture Ecosystems \& Environment 106(2-3): 261274.

de Souza, C. R., J. P. Maroco, T. P. dos Santos, M. L. Rodrigues, C. M. Lopes, J. S. Pereira and M. M. Chaves (2003). Partial rootzone drying: regulation of stomatal aperture and carbon assimilation in field-grown grapevines (Vitis vinifera cv. Moscatel). Functional Plant Biology 30(6): 653-662.

de Souza, C. R., J. P. Maroco, T. P. dos Santos, M. L. Rodrigues, C. M. Lopes, J. S. Pereira and M. M. Chaves (2005b). Impact of deficit irrigation on water use efficiency and carbon 
isotope composition (delta C-13) of field-grown grapevines under Mediterranean climate. Journal of Experimental Botany 56(418): 2163-2172.

Deloire, A., A. Carbonneau, Z. Wang and H. Ojeda (2004). Vine and water: a short review. Journal International des Sciences de la Vigne et du Vin 38(1): 13.

Delrot, S., H. Medrano, E. Or, L. Bavaresco and S. Grando (2010). Methodologies and results in grapevine research, Springer.

Deluc, L., D. Quilici, A. Decendit, J. Grimplet, M. Wheatley, K. Schlauch, J.-M. Merillon, J. Cushman and G. Cramer (2009). Water deficit alters differentially metabolic pathways affecting important flavor and quality traits in grape berries of Cabernet Sauvignon and Chardonnay. BMC Genomics 10(1): 212.

Deluc, L. G., J. Grimplet, M. D. Wheatley, R. L. Tillett, D. R. Quilici, C. Osborne, D. A. Schooley, K. A. Schlauch, J. C. Cushman and G. R. Cramer (2007). Transcriptomic and metabolite analyses of Cabernet Sauvignon grape berry development. BMC Genomics 8(429).

Diago, M. P., J. Fernández-Novales, S. Gutiérrez, M. Marañón and J. Tardaguila (2018). Development and Validation of a New Methodology to Assess the Vineyard Water Status by On-the-Go Near Infrared Spectroscopy. Frontiers in plant science 9(59).

Diago, M. P., M. Vilanova and J. Tardaguila (2010). Effects of Timing of Manual and Mechanical Early Defoliation on the Aroma of Vitis vinifera L. Tempranillo Wine. American Journal of Enology and Viticulture 61(3): 382-391.

Diffenbaugh, N. S. and F. Giorgi (2012). Climate change hotspots in the CMIP5 global climate model ensemble. Climatic Change 114(3): 813-822.

Döll, P. (2002). Impact of climate change and variability on irrigation requirements: a global perspective. Climatic Change 54(3): 269-293.

Dokoozlian, N. and Wolpert, J. (2009). Recent advances in grapevine canopy management. Proceedings of the International Symposium. Davis, CA.

dos Santos, T. P., C. M. Lopes, M. L. Rodrigues, C. R. de Souza, J. P. Maroco, J. S. Pereira, J. M. Ricardo-da-Silva and M. M. Chaves (2003). Partial rootzone drying: effects on growth and fruit quality of field-grown grapevines (Vitis vinifera). Functional Plant Biology 30(6): 663-671. 
dos Santos, T. P., C. M. Lopes, M. L. Rodrigues, C. R. de Souza, J. M. Ricardo-da-Silva, J. P. Maroco, J. S. Pereira and M. M. Chaves (2007). Effects of deficit irrigation strategies on cluster microclimate for improving fruit composition of Moscatel field-grown grapevines. Scientia Horticulturae 112(3): 321-330.

Downey, M. O., N. K. Dokoozlian and M. P. Krstic (2006). Cultural practice and environmental impacts on the flavonoid composition of grapes and wine: a review of recent research. American Journal of Enology and Viticulture 57(3): 257-268.

Dry, P. R. (2000). Canopy management for fruitfulness. Australian Journal of Grape and Wine Research 6(2): 109-115.

Duchêne, E. and C. Schneider (2005). Grapevine and climatic changes: a glance at the situation in Alsace. Agronomy for Sustainable Development 25(1): 93-99.

Dunn, G. M. (2005). Factors that control flower formation in grapevines. Transforming flowers to fruit. Australian Society of Viticulture and Oenology, Mildura, Victoria: 11-18.

El-Ansary, D. O., S. Nakayama, K. Hirano and G. Okamoto (2005). Response of Muscat of Alexandria table grapes to post-veraison regulated deficit irrigation in Japan. 2015 44(1).

Escalona, J., J. Bota and H. Medrano (2003). Distribution of leaf photosynthesis and transpiration within grapevine canopies under different drought conditions. VITIS-Journal of Grapevine Research 42(2): 57.

Escalona, J. M., M. Tomàs, S. Martorell, H. Medrano, M. Ribas-Carbo and J. Flexas (2012). Carbon balance in grapevines under different soil water supply: importance of whole plant respiration. Australian Journal of Grape and Wine Research 18(3): 308-318.

Esteban, M. A., M. J. Villanueva and J. R. Lissarrague (1999). Effect of irrigation on changes in berry composition of Tempranillo during maturation. Sugars, organic acids, and mineral elements. American Journal of Enology and Viticulture 50(4): 418-434.

Esteban, M. A., M. J. Villanueva and J. R. Lissarrague (2001). Effect of irrigation on changes in the anthocyanin composition of the skin of cv Tempranillo (Vitis vinifera L) grape berries during ripening. Journal of the Science of Food and Agriculture 81(4): 409-420.

FAO, F. a. A. O. o. t. U. N. (2011). The state of the world's land and water resources for food and agriculture. Rome and Earthscan, London

Favero, A., D. Angelucci de Amorim, R. Vieira da Mota, A. Soares, C. de Souza and M. de Albuquerque Regina (2011). Double-pruning of 'Syrah' grapevines: a management 
strategy to harvest wine grapes during the winter in the Brazilian Southeast. Vitis 50(4): 151-158.

Fereres, E., D. A. Goldhamer and L. R. Parsons (2003). Irrigation water management of horticultural crops. HortScience 38(5): 1036-1042.

Fereres, E., F. Orgaz and F. Villalobos (1993). Water use efficiency in sustainable agricultural systems. International Crop Science I(internationalcr): 83-89.

Fernandes de Oliveira, A., L. Mercenaro, A. Del Caro, L. Pretti and G. Nieddu (2015). Distinctive anthocyanin accumulation responses to temperature and natural UV radiation of two field-grown Vitis vinifera L. cultivars. Molecules 20(2): 2061-2080.

Ferrara, G., M. Fracchiolla, A. C. Ziad, S. Camposeo, C. Lasorella, A. Pacifico, A. Aly and P. Montemurro (2012). Effects of Mulching Materials on Soil and Performance of cv. Uva di Troia Grapevines in Apulia region, Southeastern Italy. American Journal of Enology and Viticulture.

Ferreyra, R. E., G. V. Sellés, R. S. Ruiz and I. M. Sellés (2003). Effect of Water Stress Applied at Different Development Periods of Grapevines cv. Chardonnay on Production and Wine Quality. Agricultura Técnica 63(3): 277-286.

Ferrise, R., G. Trombi, M. Moriondo and M. Bindi (2016). Climate change and grapevines: A simulation study for the Mediterranean basin. Journal of Wine Economics 11(1): 88-104.

Field, C. B. (2001). Plant physiology of the "missing" carbon sink. Plant Physiology 125(1): 25-28.

Filippetti, I., N. Movahed, G. Allegro, G. Valentini, C. Pastore, E. Colucci and C. Intrieri (2015). Effect of post-veraison source limitation on the accumulation of sugar, anthocyanins and seed tannins in Vitis vinifera cv. Sangiovese berries. Australian Journal of Grape and Wine Research 21(1): 90-100.

Flexas, J., J. Bota, J. Cifre, J. Mariano Escalona, J. Galmés, J. Gulías, E.-K. Lefi, S. Florinda Martínez-Cañellas, M. Teresa Moreno, M. Ribas-Carbó, D. Riera, B. Sampol and H. Medrano (2004). Understanding down-regulation of photosynthesis under water stress: future prospects and searching for physiological tools for irrigation management. Annals of Applied Biology 144(3): 273-283.

Flexas, J., J. Galmés, A. Gallé, J. Gulías, A. Pou, M. Ribas-Carbo, M. Tomàs and H. Medrano (2010). Improving water use efficiency in grapevines: potential physiological 
targets for biotechnological improvement. Australian Journal of Grape and Wine Research 16: 106-121.

Flexas, J. and H. Medrano (2002). Drought-inhibition of photosynthesis in C3 plants: stomatal and non-stomatal limitations revisited. Annals of Botany 89(2): 183-189.

Fort, K. P., K. M. Lowe, W. A. Thomas and M. A. Walker (2013). Cultural Conditions and Propagule Type Influence Relative Chloride Exclusion in Grapevine Rootstocks. American Journal of Enology and Viticulture 64(2): 241-250.

Fortuny, D. (2015). Climate change and precipitation trends in the northern Mediterranean. PhD Thesis, Departament d'Astronomia i Meteorologia, Universitat de Barcelona. (http://hdl.handle.net/2445/68303).

Friend, A. P. (2005). Berry set and development in Vitis vinifera L, PhD Thesis, Lincoln University.

Friend, A. P. and M. C. T. Trought (2007). Delayed winter spur-pruning in New Zealand can alter yield components of Merlot grapevines. Australian Journal of Grape and Wine Research 13(3): 157-164.

Frioni, T., S. Tombesi, O. Silvestroni, V. Lanari, A. Bellincontro, P. Sabbatini, M. Gatti, S. Poni and A. Palliotti (2016). Post-Budburst Spur-Pruning Reduces Yield and Delays Fruit Sugar Accumulation in cv. Sangiovese in Central Italy. American Journal of Enology and Viticulture: ajev. 2014.14036.

Fuentes, S., R. De Bei and S. Tyerman (2012). Computational water stress indices obteined from thermal image analysis of grapevine canopies. Irrigation Science 30: 523-536.

Fuentes, S., W. Sullivan, J. Tilbrook and S. D. Tyerman (2010). A novel analysis of grapevine berry tissue demonstrates a variety-dependent correlation between tissue vitality and berry shrivel. Australian Journal of Grape and Wine Research 16(2): 327-336.

Gambetta, G. A. (2016). Water stress and grape physiology in the context of global climate change. Journal of Wine Economics 11(01): 168-180.

Gamon, J. A. and R. W. Pearcy (1990). Photoinhibition in Vitis californica: the role of temperature during high-light treatment. Plant Physiology 92(2): 487-494.

García Escudero, E., P. Santamaría, R. López and I. Palacios (1991). Aplicación de dosis moderadas de agua en el proceso de maduración del cv. Tempranillo en Rioja. Vitivinicultura 2(1): 30-34. 
Gates, L. D. and S. Liess (2001). Impacts of deforestation and afforestation in the Mediterranean region as simulated by the MPI atmospheric GCM. Global and Planetary Change 30(3): 309-328.

Gatti, M., F. J. Pirez, G. Chiari, S. Tombesi, A. Palliotti, M. C. Merli and S. Poni (2016). Phenology, Canopy Aging and Seasonal Carbon Balance as Related to Delayed Winter Pruning of Vitis vinifera L. cv. Sangiovese Grapevines. Frontiers in plant science 7: 659.

Gatti, M. and S. Poni (2018). Calibrated, delayed-cane winter pruning controls yield and significantly postpones berry ripening parameters in Vitis vinifera L. cv. Pinot Noir. Australian Journal of Grape and Wine Research.

Giacosa, S., F. Marengo, S. Guidoni, L. Rolle and J. J. Hunter (2015). Anthocyanin yield and skin softening during maceration, as affected by vineyard row orientation and grape ripeness of Vitis vinifera L. cv. Shiraz. Food Chemistry 174: 8-15.

Giannakopoulos, C., P. Le Sager, M. Bindi, M. Moriondo, E. Kostopoulou and C. M. Goodess (2009). Climatic changes and associated impacts in the Mediterranean resulting from a $2{ }^{\circ} \mathrm{C}$ global warming. Global and Planetary Change 68(3): 209-224.

Ginestar, C., J. Eastham, S. Gray and P. Iland (1998). Use of sap-flow sensors to schedule vineyard irrigation. I. Effects of post-veraison water deficits on water relations, vine growth, and yield of Shiraz grapevines. American Journal of Enology and Viticulture 49(4): 413-420.

Giorgi, F. (2002). Variability and trends of sub-continental scale surface climate in the twentieth century. Part II: AOGCM simulations. Climate Dynamics 18(8): 693-708.

Girona, J., J. Marsal, M. Mata, J. del Campo and B. Basile (2009). Phenological sensitivity of berry growth and composition of Tempranillo grapevines (Vitis vinifera L.) to water stress. Australian Journal of Grape and Wine Research 15(3): 268-277.

Gladstones, J. S. (2011). Wine, terroir and climate change. Kent Town, South Australia, Wakefield Press.

Glenn, D. M., N. Cooley, R. Walker, P. Clingeleffer and K. Shellie (2010). Impact of kaolin particle film and water deficit on wine grape water use efficiency and plant water relations. HortScience 45(8): 1178-1187.

Gómez-del-Campo, M., C. Ruiz and J. R. Lissarrague (2002). Effect of Water Stress on Leaf Area Development, Photosynthesis, and Productivity in Chardonnay and Airén Grapevines. American Journal of Enology and Viticulture 53(2): 138-143. 
Gómez, I., J. Revert, V. Lizama, M. J. García-Esparza, I. Álvarez, A. Martĩnez, J. Jiménez and D. S. Intrigliolo (2011). Effects of post-veraison irrigation dose on 'Cabernet Sauvignon' vines in a dry and warm season in Valencia, Spain, VIII International Terroir Congress: 375380.

Grace, W. J., V. O. Sadras and P. T. Hayman (2009). Modelling heatwaves in viticultural regions of southeastern Australia. Australian Meteorological and Oceanographic Journal 58(4): 249-262.

Grappadelli, L. C., A. N. Lakso and J. A. Flore (1994). Early Season Patterns of Carbohydrate Partitioning in Exposed and Shaded Apple Branches. Journal of the American Society for Horticultural Science 119(3): 596-603.

Greer, D. H. and C. Weston (2010). Heat stress affects flowering, berry growth, sugar accumulation and photosynthesis of Vitis vinifera cv. Semillon grapevines grown in a controlled environment. Functional Plant Biology 37(3): 206-214.

Greven, M., S. Green, S. Neal, B. Clothier, M. Neal, G. Dryden and P. Davidson (2005). Regulated Deficit Irrigation (RDI) to save water and improve Sauvignon Blanc quality? Water Science and Technology 51(1): 9-17.

Griesser, M., R. Eder, S. Besser and A. Forneck (2012). Berry shrivel of grapes in Austria - Aspects of the physiological disorder with cultivar Zweigelt (Vitis vinifera L.). Scientia Horticulturae 145(0): 87-93.

Grifoni, D., G. Carreras, G. Zipoli, F. Sabatini, A. Dalla Marta and S. Orlandini (2008). Row orientation effect on UV-B, UV-A and PAR solar irradiation components in vineyards at Tuscany, Italy. International Journal of Biometeorology 52(8): 755-763.

Grimes, D. W. and L. E. Williams (1990). Irrigation Effects on Plant Water Relations and Productivity of Thompson Seedless Grapevines. Crop Science 30(2).

Grimplet, J., L. G. Deluc, G. R. Cramer and J. C. Cushman (2007). Integrating functional genomics with abiotic stress responses in wine grape - Vitis vinifera. Advances in Molecular Breeding towards Salinity and Drought Tolerance. M. A. Jenks, P. M. Hasegawa and S. M. Jain. Dordrecht, Springer.

Gu, S., S. D. Jacobs, B. S. McCarthy and H. L. Gohil (2012). Forcing vine regrowth and shifting fruit ripening in a warm region to enhance fruit quality in 'Cabernet Sauvignon' grapevine (Vitis vinifera L.). Journal of Horticultural Science \& Biotechnology 87(4): 287292. 
Guidoni, S., A. Ferrandino and V. Novello (2008). Effects of seasonal and agronomical practices on skin anthocyanin profile of Nebbiolo grapes. American Journal of Enology and Viticulture 59(1): 22-29.

Hale, C. R. and M. S. Buttrose (1974). Effect of temperature on ontogeny of berries of Vitis vinifera L. cv Cabernet Sauvignon. Journal of the American Society for Horticultural Science 99(5): 390-394.

Hannah, L., P. R. Roehrdanz, M. Ikegami, A. V. Shepard, M. R. Shaw, G. Tabor, L. Zhi, P. A. Marquet and R. J. Hijmans (2013). Climate change, wine, and conservation. Proceedings of the National Academy of Sciences 110(17): 6907-6912.

Hardie, W. J. and J. A. Considine (1976). Response of grapes to water-deficit stress in particular stages of development. American Journal of Enology and Viticulture 27(2): 55-61.

Hidalgo, L. (1999). Tratado de Viticultura General (Mundi-Prensa: Madrid, Spain).

Hochberg, U., F. E. Rockwell, N. M. Holbrook and H. Cochard (2017). Iso/Anisohydry: A Plant-Environment Interaction Rather Than a Simple Hydraulic Trait. Trends in Plant Science.

Holzapfel, B. P., J. P. Smith, R. M. Mandel and M. Keller (2006). Manipulating the Postharvest Period and Its Impact on Vine Productivity of Semillon Grapevines. American Journal of Enology and Viticulture 57(2): 148-157.

Howell, G. S. (2001). Sustainable Grape Productivity and the Growth-Yield Relationship: A Review. American Journal of Enology and Viticulture 52(3): 165-174.

Hsiao, T. C. (1973). Plant Responses to Water Stress. Annual Review of Plant Physiology 24(1): 519-570.

Hsiao, T. C., P. Steduto and E. Fereres (2007). A systematic and quantitative approach to improve water use efficiency in agriculture. Irrigation Science 25(3): 209-231.

Huglin, P. (1978). Nouveau mode d'évaluation des possibilités héliothermiques d'un milieu viticole. Proceedings of the Symposium International sur l'ecologie de la Vigne. Ministère de l'Agriculture et de l'Industrie Alimentaire, Contança. : 89-98.

Huglin, P. and C. Schneider (1998). Biologie et écologie de la vigne.

Hunter, J. J., C. G. Volschenk and M. Booyse (2017). Vineyard row orientation and grape ripeness level effects on vegetative and reproductive growth characteristics of Vitis vinifera L. cv. Shiraz/101-14 Mgt. European Journal of Agronomy 84: 47-57. 
Hunter, J. J., C. G. Volschenk and R. Zorer (2016). Vineyard row orientation of Vitis vinifera L. cv. Shiraz/101-14 Mgt: Climatic profiles and vine physiological status. Agricultural and Forest Meteorology 228: 104-119.

Iba, K. (2002). Acclimative response to temperature stress in higher plants: Approaches of gene engineering for temperature tolerance. Annual Review of Plant Biology 53(1): 225-245.

Iland, P., N. Bruer, A. Edwards, S. Weeks and E. Wilkes (2004). Chemical analysis of grapes and wine: techniques and concepts. Campbelltown, South Australia, Patrick Iland Wine Promotions PTY LTD.

Iland, P., P. Gago and R. Humphrys (2002). Australian wine: Styles and tastes, Patrick Iland Wine Promotions.

Intrieri, C., I. Fillippetti, G. Allegro, G. Valentini, C. Pastore and E. Colucci (2017). Results of five-year trial to delay ripening of cv. Sangiovese (Vitis vinifera L.) by late mechanical defoliation. 20th GiESCO International Meeting Professional day - full manuscripts(November 5th - 10th).

Intrieri, C., S. Poni, B. Rebucci and E. Magnanini (1998). Row orientation effects on whole-canopy gas exchange ofpotted and field-grown grapevines. Vitis 37(4): 147-154.

Intrieri, C., O. Silvestroni, B. Rebucci, S. Poni and I. Filippetti (1996). The effects of row orientation on growth, yield, quality and dry matter partitioning in Chardonnay vines trained to simple curtain and spur-pruned cordon. T. H. Kling, T. E. Wolf, W. M. Harkeness (Eds.) Proc. 4th Intern. Cool Climate Symp., 16-20 July. Rochester: 10-15.

Intrigliolo, D. and J. Castel (2006). Vine and soil-based measures of water status in a Tempranillo vineyard. VITIS-Journal of Grapevine Research 45(4): 157.

Intrigliolo, D. and J. Castel (2010). Response of grapevine cv. 'Tempranillo' to timing and amount of irrigation: water relations, vine growth, yield and berry and wine composition. Irrigation Science 28(2): 113-125.

Intrigliolo, D. S. and J. R. Castel (2007). Evaluation of grapevine water status from trunk diameter variations. Irrigation Science 26(1): 49-59.

Intrigliolo, D. S. and J. R. Castel (2008). Effects of Irrigation on the Performance of Grapevine cv. Tempranillo in Requena, Spain. American Journal of Enology and Viticulture 59(1): 30-38. 
Intrigliolo, D. S. and J. R. Castel (2011). Interactive effects of deficit irrigation and shoot and cluster thinning on grapevine cv. Tempranillo. Water relations, vine performance and berry and wine composition. Irrigation Science 29(6): 443-454.

Intrigliolo, D. S., D. Perez, D. Risco, A. Yeves and J. R. Castel (2012). Yield components and grape composition responses to seasonal water deficits in Tempranillo grapevines. Irrigation Science 30(5): 339-349.

IPCC, I. P. o. C. C. (2012). Managing the Risks of Extreme Events and Disasters to Advance Climate. Change Adaptation. Special Report of Working Groups I and II [Field, C.B., V. Barros, T.F. Stocker,

D. Qin, D.J. Dokken, K.L. Ebi, M.D. Mastrandrea, K.J. Mach, G.-K. Plattner, S.K. Allen, M. Tignor, and P.M. Midgley (eds.)]. Cambridge University Press, Cambridge, UK, and New York, NY, USA: 582 pp.

IPCC, I. P. o. C. C. (2014). Climate Change 2014: Synthesis Report. Contribution of Working Groups I, II and III to the Fifth Assessment Report of the Intergovernmental Panel on Climate Change. Core Writing Team, R.K. Pachauri and L.A. Meyer (eds.). IPCC, Geneva, Switzerland: $151 \mathrm{pp}$.

Jackson, D. I. and P. B. Lombard (1993). Environmental and management practices affecting grape composition and wine quality American Journal of Enology and Viticulture 44(4): 409-430.

Jiménez-Bello, M., C. Ballester, J. Castel and D. Intrigliolo (2011). Development and validation of an automatic thermal imaging process for assessing plant water status. Agricultural Water Management 98(10): 1497-1504.

Jones, G., M. White, O. Cooper and K. Storchmann (2005a). Climate change and global wine quality. Climatic Change 73(3): 319-343.

Jones, G. V. and R. E. Davis (2000). Climate influences on grapevine phenology, grape composition, and wine production and quality for Bordeaux, France. American Journal of Enology and Viticulture 51(3): 249-261.

Jones, G. V., E. Duchêne, D. Tomasi, J. Yuste, O. Braslavska, H. Schultz, C. Martinez, S. Boso, F. Langellier, C. Perruchot and G. Guimberteau (2005b). Changes in European winegrape phenology and relationships with climate. Geisenheim, Groupe d'Etude des Systemes de COnduite de la vigne (GESCO): 54-61. 
Jones, G. V. and L. B. Webb (2010). Climate Change, Viticulture, and Wine: Challenges and Opportunities. Journal of Wine Research 21(2-3): 103-106.

Jones, H., M. Stoll, T. Santos, C. de Sousa, M. Chaves and O. Grant (2002). Use of infrared thermography for monitoring stomatal closure in the field: application to grapevine. Journal of Experimental Botany 53(378): 2249-2260.

Jones, H. G. (1992). Energy balance and evaporation. Plants and microclimate: a quantitative approach to environmental plant physiology. C. U. Press. Malta, Cambridge University Press: 106-130.

Junquera, P., J. R. Lissarrague, L. Jiménez, R. Linares and P. Baeza (2012). Long-term effects of different irrigation strategies on yield components, vine vigour, and grape composition in cv. Cabernet-Sauvignon (Vitis vinifera L.). Irrigation Science 30(5): 351-361.

Keller, M., Mills, L. J., Wample, R. L. and Spayd, S. E. (2004). Crop Load Management in Concord Grapes Using Different Pruning Techniques. American Journal of Enology and Viticulture 55(1): 35-50.

Keller, M. (2005). Deficit irrigation and vine mineral nutrition. American Journal of Enology and Viticulture 56(3): 267-283.

Keller, M. (2010a). Managing grapevines to optimise fruit development in a challenging environment: a climate change primer for viticulturists. Australian Journal of Grape and Wine Research 16: 56-69.

Keller, M. (2010b). The science of grapevines: anatomy and physiology. San Diego, USA, Elsevier academic Press.

Keller, M., P. Romero, H. Gohil, R. P. Smithyman, W. R. Riley, L. F. Casassa and J. F. Harbertson (2016). Deficit Irrigation Alters Grapevine Growth, Physiology, and Fruit Microclimate. American Journal of Enology and Viticulture 67(4): 426-435.

Keller, M., R. P. Smithyman and L. J. Mills (2008). Interactive effects of deficit irrigation and crop load on cabernet sauvignon in an arid climate. American Journal of Enology and Viticulture 59(3): 221-234.

Keller, M., Y. Zhang, P. M. Sherstha, M. Biondi and B. R. Bondada (2015). Sugar demand of ripening grape berries leads to recycling of surplus phloem water via the xylem. Plant, Cell \& Environment 38(6): 1048-1059. 
Kennedy, J. A., M. A. Matthews and A. L. Waterhouse (2002). Effect of maturity and vine water status on grape skin and wine flavonoids. American Journal of Enology and Viticulture 53(4): 268-274.

Kliewer, W. M. (1977). Influence of temperature, solar-radiation and nitrogen on coloration and composition of Emperor grapes. American Journal of Enology and Viticulture 28(2): 96-103.

Kliewer, W. M. and A. J. Antcliff (1970). Influence of defoliation, leaf darkening, and cluster shading on the growth and composition of sultana grapes. American Journal of Enology and Viticulture 21(1): 26-36.

Kliewer, W. M. and N. K. Dokoozlian (2005). Leaf Area/Crop Weight Ratios of Grapevines: Influence on Fruit Composition and Wine Quality. American Journal of Enology and Viticulture 56(2): 170-181.

Kliewer, W. M., L. A. Lider and H. B. Schultz (1967). Influence of Artificial Shading of Vineyards on the Concentration of Sugar and Organic Acid in Grapes. American Journal of Enology and Viticulture 18(2): 78-86.

Kliewer, W. M. and H. B. Schultz (1973). Effect of sprinkler cooling of grapevines on fruit growth and composition. American Journal of Enology and Viticulture 24(1): 17-26.

Kliewer, W. M. and R. J. Weaver (1971). Effect of crop level and leaf area on growth, composition, and coloration of Tokay grapes. American Journal of Enology and Viticulture 22(3): 172-\&.

Köppen, W. (1936). Das geographische System der Klimate (Handbuch der Klimatologie, Bd. 1, Teil C). Apud. Beck, C.

Koufos, G., T. Mavromatis, S. Koundouras, N. M. Fyllas and G. V. Jones (2014). Viticulture-climate relationships in Greece: the impacts of recent climate trends on harvest date variation. International Journal of Climatology 34(5): 1445-1459.

Kriedemann, P. (1968). Photosynthesis In Vine Leaves As A Function Of Light Intensity Temperature And Leaf Age Vol-7, MPKV; Maharastra.

Kueppers, L. M., M. A. Snyder and L. C. Sloan (2007). Irrigation cooling effect: Regional climate forcing by land-use change. Geophysical Research Letters 34(3): n/a-n/a.

Lal, R. (2002). The potential of soils of the tropics to sequester carbon and mitigate the greenhouse effect. Advances in Agronomy 76: 1-30. 
Lal, R. (2004). Soil carbon sequestration to mitigate climate change. Geoderma 123(1): 1-22.

Lanari, V., T. Lattanzi, L. Borghesi, O. Silvestroni and A. Palliotti (2013). Post-veraison mechanical leaf removal delays berry ripening on 'Sangiovese' and 'Montepulciano' grapevines, International Society for Horticultural Science (ISHS), Leuven, Belgium.

Lavee, H., A. C. Imeson and P. Sarah (1998). The impact of climate change on geomorphology and desertification along a mediterranean-arid transect. Land Degradation \& Development 9(5): 407-422.

Lavoie-Lamoureux, A., D. Sacco, P.-A. Risse and C. Lovisolo (2017). Factors influencing stomatal conductance in response to water availability in grapevine: a metaanalysis. Physiologia Plantarum 159(4): 468-482.

Lebon, E. (2002). Changements climatiques: quelles conséquences pour la viticulture. CR 6ième Rencontres Rhodaniennes: 31-36.

Lebon, G., G. Wojnarowiez, B. Holzapfel, F. Fontaine, N. Vaillant-Gaveau and C. Clément (2008). Sugars and flowering in the grapevine (Vitis vinifera L.). Journal of Experimental Botany 59(10): 2565-2578.

Lereboullet, A.-L., G. Beltrando, D. Bardsley and E. Rouvellac (2013a). The viticultural system and climate change: coping with long-term trends in temperature and rainfall in Roussillon, France. Regional Environmental Change: 1-16.

Lereboullet, A.-L., G. Beltrando and D. K. Bardsley (2013b). Socio-ecological adaptation to climate change: A comparative case study from the Mediterranean wine industry in France and Australia. Agriculture, Ecosystems \& Environment 164(Supplement C): 273-285.

Lobell, D. B., C. J. Bonfils, L. M. Kueppers and M. A. Snyder (2008). Irrigation cooling effect on temperature and heat index extremes. Geophysical Research Letters 35(9).

Lopes, C. M., Santos, T. P., Monteiro, A., Lucilia Rodrigues, M., Costa, J. M. and Manuela Chaves, M. (2011). Combining cover cropping with deficit irrigation in a Mediterranean low vigor vineyard. Scientia Horticulturae 129(4): 603-612.

Lopez-Bustins, J.-A., E. Pla, M. Nadal, F. de Herralde and R. Savé (2014). Global change and viticulture in the Mediterranean region: a case of study in north-eastern Spain. Spanish Journal of Agricultural Research 12(1): 78-88. 
López-Urrea, R., A. Montoro, F. Mañas, P. López-Fuster and E. Fereres (2012). Evapotranspiration and crop coefficients from lysimeter measurements of mature 'Tempranillo' wine grapes. Agricultural Water Management 112: 13-20.

López-Urrea, R., A. Montoro, L. Martínez, F. Mañas, J. Sánchez and D. Intrigliolo (2016). $i$ Es posible mejorar la eficiencia en el uso del agua de un viñedo mediante un acolchado orgánico del suelo? XXXIV Congreso Nacional de Riegos, Sevilla 2016, Escuela Universitaria de Ingeniería Técnica Agrícola.

López, M.-I., M.-T. Sánchez, A. Díaz, P. Ramírez and J. Morales (2007). Influence of a deficit irrigation regime during ripening on berry composition in grapevines (Vitis vinifera L.) grown in semi-arid areas. International Journal of Food Sciences and Nutrition 58(7): 491-507.

Lorenz, D. H., K. W. Eichhorn, H. Bleiholder, R. Klose, U. Meier and E. Weber (1995). Growth Stages of the Grapevine: Phenological growth stages of the grapevine (Vitis vinifera L. ssp. vinifera)-Codes and descriptions according to the extended BBCH scale†. Australian Journal of Grape and Wine Research 1(2): 100-103.

Louarn, G., J. Dauzat, J. Lecoeur and E. Lebon (2008). Influence of trellis system and shoot positioning on light interception and distribution in two grapevine cultivars with different architectures: an original approach based on 3D canopy modelling. Australian Journal of Grape and Wine Research 14(3): 143-152.

Lovisolo, C., I. Perrone, A. Carra, A. Ferrandino, J. Flexas, H. Medrano and A. Schubert (2010). Drought-induced changes in development and function of grapevine (Vitis spp.) organs and in their hydraulic and non-hydraulic interactions at the whole-plant level: a physiological and molecular update. Functional Plant Biology 37(2): 98-116.

Lovisolo, C. and A. Schubert (1998). Effects of water stress on vessel size and xylem hydraulic conductivity in Vitis vinifera L. Journal of Experimental Botany 49(321): 693-700.

Mabrouk, H. and H. Sinoquet (1998). Indices of light microclimate and canopy structure of grapevines determined by 3D digitising and image analysis, and their relationship to grape quality. Australian Journal of Grape and Wine Research 4(1): 2-13.

Mabrouk, H., H. Sinoquet and A. Carbonneau (1997). Canopy structure and radiation regime in grapevine. II. Modeling radiation interception and distribution inside the canopy. VITIS-GEILWEILERHOF- 36: 125-132. 
MAPAMA, M. d. A. y. P., Alimentación y Medio Ambiente (2015). Encuesta de Viñedo. Secretaría General Técnica, Subdirección General de Estadística.

MAPAMA, M. d. A. y. P., Alimentación y Medio Ambiente (2016). Encuesta sobre superficies y rendimientos, resultados nacionales y autonómicos.

Marais, J., J. Hunter and P. Haasbroek (1999). Effect of canopy microclimate, season and region on Sauvignon blanc grape composition and wine quality. South African Journal of Enology and Viticulture 20(1): 19-30.

Mark, B. (1996). World's Earliest Wine. Archaeology (Archaeological Institute of America) 49(5).

Martin, S. R. and G. M. Dunn (2000). Effect of pruning time and hydrogen cyanamide on budburst and subsequent phenology of Vitis vinifera L. variety Cabernet Sauvignon in central Victoria. Australian Journal of Grape and Wine Research 6(1): 31-39.

Martínez-Lüscher, J., T. Kizildeniz, V. Vučetić, Z. Dai, E. Luedeling, C. van Leeuwen, E. Gomès, I. Pascual, J. J. Irigoyen, F. Morales and S. Delrot (2016). Sensitivity of Grapevine Phenology to Water Availability, Temperature and CO2 Concentration. Frontiers in Environmental Science 4(48).

Martínez-Lüscher, J., F. Morales, S. Delrot, M. Sánchez-Díaz, E. Gomès, J. Aguirreolea and I. Pascual (2015a). Characterization of the adaptive response of grapevine (cv. Tempranillo) to UV-B radiation under water deficit conditions. Plant Science 232: 13-22.

Martínez-Lüscher, J., F. Morales, M. Sánchez-Díaz, S. Delrot, J. Aguirreolea, E. Gomès and I. Pascual (2015b). Climate change conditions (elevated CO2 and temperature) and UVB radiation affect grapevine (Vitis vinifera cv. Tempranillo) leaf carbon assimilation, altering fruit ripening rates. Plant Science 236(Supplement C): 168-176.

Martinez de Toda, F., J. C. Sancha, W. Zheng and P. Balda (2015). Leaf area reduction by trimming, a growing technique to restore the anthocyanins : sugars ratio decoupled by the warming climate. 2014 53(4).

Martorell, S., A. Diaz-Espejo, M. Tomàs, A. Pou, H. El Aou-ouad, J. M. Escalona, J. Vadell, M. Ribas-Carbó, J. Flexas and H. Medrano (2015). Differences in water-use-efficiency between two Vitis vinifera cultivars (Grenache and Tempranillo) explained by the combined response of stomata to hydraulic and chemical signals during water stress. Agricultural Water Management 156(Supplement C): 1-9. 
Mastin, M. C. (2008). Effects of potential future warming on runoff in the Yakima River Basin, Washington, Geological Survey (US).

Matthews, M. A. and M. M. Anderson (1988). Fruit ripening in Vitis vinifera L.: responses to seasonal water deficits. American Journal of Enology and Viticulture 39(4): 313-320.

May, P. (2004). Flowering and Fruitset in Grapevines. Lythrum Press.

McCarthy, M., B. Loveys, P. Dry and M. Stoll (2002). Regulated deficit irrigation and partial rootzone drying as irrigation management techniques for grapevines. Deficit irrigation practices, FAO Water Reports 22: 79-87.

McCarthy, M. G. (1997). The effect of transient water deficit on berry development of cv. Shiraz (Vitis vinifera L.). Australian Journal of Grape and Wine Research 3(3): 2-8.

McCarthy, M. G. (2000). Developmental variation in sensitivity of Vitis vinifera L. (Shiraz) berries to soil water deficit. Australian Journal of Grape and Wine Research 6(2): 136-140.

McClymont, L., I. Goodwin, M. Mazza, N. Baker, D. M. Lanyon, A. Zerihun, S. Chandra and M. O. Downey (2012). Effect of site-specific irrigation management on grapevine yield and fruit quality attributes. Irrigation Science 30(6): 461-470.

Medrano, H., J. M. Escalona, J. Cifre, J. Bota and J. Flexas (2003). A ten-year study on the physiology of two Spanish grapevine cultivars under field conditions: effects of water availability from leaf photosynthesis to grape yield and quality. Functional Plant Biology 30(6): 607-619.

Medrano, H., A. Pou, M. Tomás, S. Martorell, J. Gulias, J. Flexas and J. M. Escalona (2012). Average daily light interception determines leaf water use efficiency among different canopy locations in grapevine. Agricultural Water Management 114: 4-10.

Medrano, H., M. Tomás, S. Martorell, J.-M. Escalona, A. Pou, S. Fuentes, J. Flexas and J. Bota (2015). Improving water use efficiency of vineyards in semi-arid regions. A review. Agronomy for Sustainable Development 35(2): 499-517.

Mercurio, M. D., R. G. Dambergs, D. Cozzolino, M. J. Herderich and P. A. Smith (2010). Relationship between Red Wine Grades and Phenolics. 1. Tannin and Total Phenolics Concentrations. Journal of Agricultural and Food Chemistry 58(23): 12313-12319. 
Merli, M. C., E. Magnanini, M. Gatti, F. J. Pirez, I. Buesa, D. S. Intrigliolo and S. Poni (2016). Water stress improves whole-canopy water use efficiency and berry composition of cv. Sangiovese (Vitis vinifera L.) grapevines grafted on the new drought-tolerant rootstock M4. Agricultural Water Management 169: 106-114.

Mira de Orduña, R. (2010). Climate change associated effects on grape and wine quality and production. Food Research International 43(7): 1844-1855.

Mirás-Avalos, J. M., I. Buesa, E. Llacer, M. A. Jiménez-Bello, D. Risco, J. R. Castel and D. S. Intrigliolo (2017). Water Versus Source-Sink Relationships in a Semiarid Tempranillo Vineyard: Vine Performance and Fruit Composition. American Journal of Enology and Viticulture 68(1): 11-22.

Mirás-Avalos, J. M. and D. S. Intrigliolo (2017). Grape Composition under Abiotic Constrains: Water Stress and Salinity. Frontiers in plant science 8(851): 8 pp.

Molina-Navarro, E., D. Trolle, S. Martínez-Pérez, A. Sastre-Merlín and E. Jeppesen (2014). Hydrological and water quality impact assessment of a Mediterranean limnoreservoir under climate change and land use management scenarios. Journal of Hydrology 509: 354-366.

Möller, M., V. Alchanatis, Y. Cohen, M. Meron, J. Tsipris, A. Naor, V. Ostrovsky, M. Sprintsin and S. Cohen (2007). Use of thermal and visible imagery for estimating crop water status of irrigated grapevine. Journal of Experimental Botany 58(4): 827-838.

Monteith, J. L. and C. J. Moss (1977). Climate and the Efficiency of Crop Production in Britain [and Discussion].

Moran, M. A., V. O. Sadras and P. R. Petrie (2017). Late pruning and carry-over effects on phenology, yield components and berry traits in Shiraz. Australian Journal of Grape and Wine Research: n/a-n/a.

Moratiel, R., J. Durán and R. L. Snyder (2010). Responses of reference evapotranspiration to changes in atmospheric humidity and air temperature in Spain. Climate Research 44(1): 27-40.

Moratiel, R., R. L. Snyder, J. Duran and A. Tarquis (2011). Trends in climatic variables and future reference evapotranspiration in Duero Valley (Spain). Natural Hazards and Earth System Sciences 11(6): 1795-1805. 
Mori, K., N. Goto-Yamamoto, M. Kitayama and K. Hashizume (2007). Loss of anthocyanins in red-wine grape under high temperature. Journal of Experimental Botany 58(8): 1935-1945.

Mori, K., H. Saito, N. Goto-Yamamoto, M. Kitayama, S. Kobayashi, S. Sugaya, H. Gemma and K. Hashizume (2005). Effects of abscisic acid treatment and night temperatures on anthocyanin composition in Pinot noir grapes. Vitis 44(4): 161-165.

Moriondo, M., M. Bindi, C. Fagarazzi, R. Ferrise and G. Trombi (2011). Framework for high-resolution climate change impact assessment on grapevines at a regional scale. Regional Environmental Change 11(3): 553-567.

Moriondo, M., G. V. Jones, B. Bois, C. Dibari, R. Ferrise, G. Trombi and M. Bindi (2013). Projected shifts of wine regions in response to climate change. Climatic Change 119(3-4): 825-839.

Morlat, R. and R. Chaussod (2008). Long-term Additions of Organic Amendments in a Loire Valley Vineyard. I. Effects on Properties of a Calcareous Sandy Soil. American Journal of Enology and Viticulture 59(4): 353-363.

Movahed, N., C. Pastore, A. Cellini, G. Allegro, G. Valentini, S. Zenoni, E. Cavallini, E. D’Incà, G. B. Tornielli and I. Filippetti (2016). The grapevine VviPrx31 peroxidase as a candidate gene involved in anthocyanin degradation in ripening berries under high temperature. Journal of Plant Research 129(3): 513-526.

Mullins, M. G., A. Bouquet and L. E. Williams (1992). Biology of the grapevine, Cambridge University Press.

Myers, B. J. (1988). Water stress integral-a link between short-term stress and long-term growth. Tree Physiology 4(4): 315-323.

Myers, N., R. A. Mittermeier, C. G. Mittermeier, G. A. Da Fonseca and J. Kent (2000). Biodiversity hotspots for conservation priorities. Nature 403(6772): 853.

Nadal, M. and L. Arola (1995). Effects of limeted irrigation on the composition of must and wine of Cabernet Sauvignon under semi-arid conditions. VITIS-Journal of Grapevine Research 34(3): 151.

Naylor, A. P., G. L. Creasy, M. C. Trought and L. Van Hanen (2000). The effects of row orientation and fruit exposure on the juice composition of Sauvignon blanc (Vitis vinifera L.). Proceedings of the 5th International Symposium of Cool Climate Viticulture and Oenology, Melbourne. 
Nemani, R. R., M. A. White, D. R. Cayan, G. V. Jones, S. W. Running and J. C. Coughlan (2001). Asymmetric climatic warming improves California vintages. Climate Research 19(1): 25-34.

Nicholas, K. A. and W. H. Durham (2012). Farm-scale adaptation and vulnerability to environmental stresses: Insights from winegrowing in Northern California. Global Environmental Change 22(2): 483-494.

Nicotra, A. B. and A. Davidson (2010). Adaptive phenotypic plasticity and plant water use. Functional Plant Biology 37(2): 117-127.

Núñez-López, D. C., A. Ramírez-Godoy and H. Restrepo-Díaz (2015). Impact of Kaolin Particle Film and Synthetic Insecticide Applications on Whitefly Populations Trialeurodes vaporariorum (Hemiptera: Aleyrodidae) and Physiological Attributes in Bean (Phaseolus vulgaris) Crop. HortScience 50(10): 1503-1508.

OIV, O. I. d. l. V. e. d. V. (2017). State of the vitiviniculture world market.

Ojeda, H., C. Andary, E. Kraeva, A. Carbonneau and A. Deloire (2002). Influence of pre- and postveraison water deficit on synthesis and concentration of skin phenolic compounds during berry growth of Vitis vinifera cv. Shiraz. American Journal of Enology and Viticulture 53(4): 261-267.

Ollat, N., J.-M. Touzard and C. van Leeuwen (2016). Climate Change Impacts and Adaptations: New Challenges for the Wine Industry*. Journal of Wine Economics 11(1): 139149.

Ortega-Farias, S., E. Fereres and V. O. Sadras (2012). Special issue on water management in grapevines. Irrigation Science 30(5): 335-337.

Ortega-Farías, S., D. Fonseca, D. de la Fuente, A. Kilic, S. Ortega-Salazar, R. Allen and M. Carrasco-Benavides (2017). Remote sensing model to evaluate the spatial variability of vineyard water requirements. X International Symposium on Grapevine Physiology and Biotechnology 1188.

Paciello, P., F. Mencarelli, A. Palliotti, B. Ceccantoni, C. Thibon, P. Darriet, M. Pasquini and A. Bellincontro (2017). Nebulized water cooling of the canopy affects leaf temperature, berry composition and wine quality of Sauvignon blanc. Journal of the Science of Food and Agriculture 97(4): 1267-1275.

Palliotti, A. (2012). A new closing Y-shaped training system for grapevines. Australian Journal of Grape and Wine Research 18(1): 57-63. 
Palliotti, A., F. Panara, O. Silvestroni, V. Lanari, P. Sabbatini, G. Howell, M. Gatti and S. Poni (2013a). Influence of mechanical postveraison leaf removal apical to the cluster zone on delay of fruit ripening in Sangiovese (Vitis vinifera L.) grapevines. Australian Journal of Grape and Wine Research 19(3): 369-377.

Palliotti, A., F. Panara, O. Silvestroni, V. Lanari, P. Sabbatini, G. S. Howell, M. Gatti and S. Poni (2013b). Influence of mechanical postveraison leaf removal apical to the cluster zone on delay of fruit ripening in Sangiovese (Vitis vinifera L.) grapevines. Australian Journal of Grape and Wine Research 19(3): 369-377.

Palliotti, A., S. Tombesi, O. Silvestroni, V. Lanari, M. Gatti and S. Poni (2014). Changes in vineyard establishment and canopy management urged by earlier climate-related grape ripening: A review. Scientia Horticulturae 178: 43-54.

Palmer, J. (1989). Canopy manipulation for optimum utilization of light.

Palosuo, T., K. C. Kersebaum, C. Angulo, P. Hlavinka, M. Moriondo, J. E. Olesen, R. H. Patil, F. Ruget, C. Rumbaur, J. Takáč, M. Trnka, M. Bindi, B. Çaldağ, F. Ewert, R. Ferrise, W. Mirschel, L. Şaylan, B. Šiška and R. Rötter (2011). Simulation of winter wheat yield and its variability in different climates of Europe: A comparison of eight crop growth models. European Journal of Agronomy 35(3): 103-114.

Parker, A. K., I. G. de Cortázar-Atauri, C. Van Leeuwen and I. Chuine (2011). General phenological model to characterise the timing of flowering and veraison of Vitis vinifera $\mathrm{L}$. Australian Journal of Grape and Wine Research 17(2): 206-216.

Parker, A. K., R. W. Hofmann, C. Leeuwen, A. R. McLachlan and M. C. Trought (2015). Manipulating the leaf area to fruit mass ratio alters the synchrony of total soluble solids accumulation and titratable acidity of grape berries. Australian Journal of Grape and Wine Research 21(2): 266-276.

Parkin, R. and C. R. Turkington (1980). Late pruning improves wine quality. Agricultural Gazette of New South Wales 91(1): 36-37.

Passioura, J. B. (2002). Soil conditions and plant growth. Plant Cell and Environment 25(2): 311-318.

Pereira, G. E., J. P. Gaudillere, P. Pieri, G. Hilbert, M. Maucourt, C. Deborde, A. Moing and D. Rolin (2006). Microclimate Influence on Mineral and Metabolic Profiles of Grape Berries. Journal of Agricultural and Food Chemistry 54(18): 6765-6775. 
Peterlunger, E., Celotti, E., Da Dalt, G., Stefanelli, S., Gollino, G. and Zironi, R. (2002). Effect of training system on Pinot noir grape and wine composition. heuvel

53(1): 14-18.

Petrie, P. R. and V. O. Sadras (2008). Advancement of grapevine maturity in Australia between 1993 and 2006: putative causes, magnitude of trends and viticultural consequences. Australian Journal of Grape and Wine Research 14(1): 33-45.

Petrie, P. R., M. C. T. Trought, G. S. Howell and G. D. Buchan (2003). The effect of leaf removal and canopy height on whole-vine gas exchange and fruit development of Vitis vinifera L. Sauvignon Blanc. Functional Plant Biology 30(6): 711-717.

Picón-Toro, J., V. González-Dugo, D. Uriarte, L. A. Mancha and L. Testi (2012). Effects of canopy size and water stress over the crop coefficient of a "Tempranillo" vineyard in south-western Spain. Irrigation Science 30(5): 419-432.

Pirie, A. J. G. (1977). Phenolics accumulation in red wine grapes (Vitis vinifera L.), University of Sydney. Ph. D.

Poni, S., F. Bernizzoni, S. Civardi, M. Gatti, D. Porro and F. Camin (2009). Performance and water-use efficiency (single-leaf vs. whole-canopy) of well-watered and half-stressed split-root Lambrusco grapevines grown in Po Valley (Italy). Agriculture, Ecosystems \& Environment 129(1): 97-106.

Poni, S., F. Bernizzoni, P. Presutto and B. Rebucci (2004). Performance of Croatina under Short-Cane Mechanical Hedging: A Successful Case of Adaptation. American Journal of Enology and Viticulture 55(4): 379-388.

Poni, S., M. Gatti, F. Bernizzoni, S. Civardi, N. Bobeica, E. Magnanini and A. Palliotti (2013). Late leaf removal aimed at delaying ripening in cv. Sangiovese: physiological assessment and vine performance. Australian Journal of Grape and Wine Research 19(3): 378-387.

Poni, S., M. Gatti, A. Palliotti, Z. Dai, E. Duchêne, T.-T. Truong, G. Ferrara, A. M. S. Matarrese, A. Gallotta, A. Bellincontro, F. Mencarelli and S. Tombesi (2017). Grapevine quality: A multiple choice issue. Scientia Horticulturae.

Poni, S., C. Intrieri and E. Magnanini (1999). Set-up, calibration and testing of a custom-built system for measuring whole-canopy transpiration in grapevine. I ISHS Workshop on Water Relations of Grapevines 493. 
Poni, S., C. Intrieri and O. Silvestroni (1994). Interactions of Leaf Age, Fruiting, and Exogenous Cytokinins in Sangiovese Grapevines Under Non-Irrigated Conditions. I. Gas Exchange. American Journal of Enology and Viticulture 45(1): 71-78.

Poni, S., A. Lakso, J. Turner and R. Melious (1993). The effects of pre-and postveraison water stress on growth and physiology of potted Pinot Noir grapevines at varying crop levels. Vitis 32(4): 207-214.

Poni, S., E. Magnanini and F. Bernizzoni (2003). Degree of correlation between total light interception and whole-canopy net $\mathrm{CO}_{2}$ exchange rate in two grapevine growth systems. Australian Journal of Grape and Wine Research 9(1): 2-11.

Poni, S., M. C. Merli, E. Magnanini, M. Galbignani, F. Bernizzoni, A. Vercesi and M. Gatti (2014a). An improved multichamber gas exchange system for determining whole-canopy water-use efficiency in grapevine. American Journal of Enology and Viticulture 65(2): 268276.

Poni, S., M. Zamboni, A. Vercesi, A. Garavani and M. Gatti (2014b). Effects of early shoot trimming of varying severity on single high-wire trellised pinot noir grapevines. American Journal of Enology and Viticulture.

Ramos, M. C., G. V. Jones and J. A. Martínez-Casasnovas (2008). Structure and trends in climate parameters affecting winegrape production in northeast Spain. Climate Research 38: $1-15$.

Ravaz, L. and L. Sicard (1903). Sur la brunissure de la vigne. Comptes rendus de l'Académie des Sciences 136: 1276-1278.

Regina, M. d. A. and A. Carbonneau (1996). Gas exchanges in Vitis vinifera under water stress regime; 1: characterization of the variety behavior. Pesquisa Agropecuaria Brasileira (Brazil).

Reynolds, A. G., Wardle, D. A., Cliff, M. A. and King, M. (2004). Impact of Training System and Vine Spacing on Vine Performance, Berry Composition, and Wine Sensory Attributes of Seyval and Chancellor. American Journal of Enology and Viticulture 55(1): 8495.

Reynolds, A. G., W. D. Lowrey, L. Tomek, J. Hakimi and C. de Savigny (2007). Influence of Irrigation on Vine Performance, Fruit Composition, and Wine Quality of Chardonnay in a Cool, Humid Climate. American Journal of Enology and Viticulture 58(2): 217-228. 
Reynolds, A. G. and A. P. Naylor (1994). 'Pinot noir' and 'Riesling' Grapevines Respond to Water Stress Duration and Soil Water-holding Capacity. HortScience 29(12): 1505-1510.

Reynolds, A. G. and J. E. Vanden Heuvel (2009). Influence of grapevine training systems on vine growth and fruit composition: a review. American Journal of Enology and Viticulture 60(3): 251-268.

Reynolds, A. G. and D. A. Wardle (1993). Significance of viticultural and enological practices on monoterpene flavorants of British Columbia-grown Vitis vinifera berries and juices. Wein-Wissenschaft 48(3-6): 194-202.

Ribereau-Gayon, P., D. Dubourdieu, B. Donèche and A. Lonvaud (2000). Handbook of Enology, Volume 1: The Microbiology of Wine and Vinification. Chichester, UK: John Wiley \& Sons, Ltd. ISBN 0 471(97362): 9.

Riches, D., I. J. Porter, D. P. Oliver, R. G. V. Bramley, B. Rawnsley, J. Edwards and R. E. White (2013). Review: soil biological properties as indicators of soil quality in Australian viticulture. Australian Journal of Grape and Wine Research 19(3): 311-323.

Risco, D., D. Pérez, A. Yeves, J. R. Castel and D. S. Intrigliolo (2014). Early defoliation in a temperate warm and semi-arid Tempranillo vineyard: vine performance and grape composition. Australian Journal of Grape and Wine Research 20(1): 111-122.

Roby, G., J. F. Harbertson, D. A. Adams and M. A. Matthews (2004). Berry size and vine water deficits as factors in winegrape composition: anthocyanins and tannins. Australian Journal of Grape and Wine Research 10(2): 100-107.

Rogers, L., O. Gall and R. Barnette (1939). The Zinc content of weeds and volunteer grasses and planted land covers. Soil Science 47(3): 237-244.

Romero, I., E. García-Escudero and I. Martín (2010a). Effects of Leaf Position on Blade and Petiole Mineral Nutrient Concentration of Tempranillo Grapevine (Vitis vinifera L.). American Journal of Enology and Viticulture 61(4): 544-550.

Romero, P., J. I. Fernández-Fernández and A. Martinez-Cutillas (2010b). Physiological thresholds for efficient regulated deficit-irrigation management in winegrapes grown under semiarid conditions. American Journal of Enology and Viticulture 61(3): 300-312. 
Romero, P. and A. Martinez-Cutillas (2012). The effects of partial root-zone irrigation and regulated deficit irrigation on the vegetative and reproductive development of fieldgrown Monastrell grapevines. Irrigation Science 30(5): 377-396.

Rosati, A. (2007). Physiological effects of kaolin particle film technology: A review. Funct. Plant Sci. Biotech. 1: 100-105.

Rüger, S., Y. Netzer, M. Westhoff, D. Zimmermann, R. Reuss, S. Ovadiya, P. Gessner, G. Zimmermann, A. Schwartz and U. Zimmermann (2010). Remote monitoring of leaf turgor pressure of grapevines subjected to different irrigation treatments using the leaf patch clamp pressure probe. Australian Journal of Grape and Wine Research 16(3): 405-412.

Ryan, M. G. (1991). Effects of Climate Change on Plant Respiration. Ecological Applications 1(2): 157-167.

Sadras, V., M. Moran and P. Petrie (2017). Resilience of grapevine yield in response to warming. OENO One 51(4): 381-386.

Sadras, V. O. and A. M. Moran (2013). Nonlinear effects of elevated temperature on grapevine phenology Agricultural and Forest Meteorology 173 107-115.

Sadras, V. O. and M. A. Moran (2012). Elevated temperature decouples anthocyanins and sugars in berries of Shiraz and Cabernet Franc. Australian Journal of Grape and Wine Research 18(2): 115-122.

Sadras, V. O., M. A. Moran and M. Bonada (2013a). Effects of elevated temperature in grapevine. I Berry sensory traits. Australian Journal of Grape and Wine Research 19(1): 95106.

Sadras, V. O. and P. R. Petrie (2011a). Climate shifts in south-eastern Australia: early maturity of Chardonnay, Shiraz and Cabernet Sauvignon is associated with early onset rather than faster ripening. Australian Journal of Grape and Wine Research 17(2): 199-205.

Sadras, V. O. and P. R. Petrie (2011b). Quantifying the onset, rate and duration of sugar accumulation in berries from commercial vineyards in contrasting climates of Australia. Australian Journal of Grape and Wine Research 17(2): 190-198.

Sadras, V. O., P. R. Petrie and A. M. Moran (2013b). Effects of elevated temperature in grapevine. II Juice $\mathrm{pH}$, titratable acidity and wine sensory attributes Australian Journal of Grape and Wine Research 19(1): 107-115. 
Sadras, V. O., M. P. Reynolds, A. J. de la Vega, P. R. Petrie and R. Robinson (2009). Phenotypic plasticity of yield and phenology in wheat, sunflower and grapevine. Field Crops Research 110(3): 242-250.

Sadras, V. O. and R. A. Richards (2014). Improvement of crop yield in dry environments: benchmarks, levels of organisation and the role of nitrogen. Journal of Experimental Botany 65(8): 1981-1995.

Sadras, V. O. and H. Schultz (2012). Crop yiel response to water. FAO irrigation and drainage paper \# 66. P. Steduto, T. C. Hsiao, E. Fereres and D. Raes. via delle Terme di Caracalla, Roma, Italy, Food and Agriculture Organization of the United Nations.

Sadras, V. O., R. M. Stevens, J. M. Pech, E. J. Taylor, P. R. Nicholas and M. G. McCarthy (2007). Quantifying phenotypic plasticity of berry traits using an allometric-type approach: A case study on anthocyanins and sugars in berries of Cabernet Sauvignon. Australian Journal of Grape and Wine Research 13(2): 72-80.

Sage, R. F. and D. S. Kubien (2007). The temperature response of C3 and C4 photosynthesis. Plant, cell \& environment 30(9): 1086-1106.

Salazar-Parra, C., J. Aguirreolea, M. Sánchez-Díaz, J. J. Irigoyen and F. Morales (2010). Effects of climate change scenarios on Tempranillo grapevine (Vitis vinifera L.) ripening: response to a combination of elevated $\mathrm{CO} 2$ and temperature, and moderate drought. Plant and Soil 337(1): 179-191.

Salazar-Parra, C., J. Aguirreolea, M. Sánchez-Díaz, J. J. Irigoyen and F. Morales (2012). Photosynthetic response of Tempranillo grapevine to climate change scenarios. Annals of Applied Biology 161(3): 277-292.

Salinari, F., S. Giosue, F. N. Tubiello, A. Rettori, V. Rossi, F. Spanna, C. Rosenzweig and M. L. Gullino (2006). Downy mildew (Plasmopara viticola) epidemics on grapevine under climate change. Global Change Biology 12(7): 1299-1307.

Salón, J., J. Mendez, C. Chirivella and J. Castel (2004). Response of Vitis Vinifera cv.'Bobal' and 'Tempranillo' to deficit irrigation. International Symposium on Irrigation and Water relations in Grapevine and fruit Trees. Acta Horticulturae. 167-174.

Salón, J. L., C. Chirivella and J. R. Castel (2005). Response of cv. Bobal to timing of deficit irrigation in Requena, Spain: water relations, yield, and wine quality. American Journal of Enology and Viticulture 56(1): 1-8. 
Santesteban, L., C. Miranda, I. Barbarin and J. Royo (2015). Application of the measurement of the natural abundance of stable isotopes in viticulture: a review. Australian Journal of Grape and Wine Research 21(2): 157-167.

Santesteban, L., C. Miranda and J. Royo (2011a). Regulated deficit irrigation effects on growth, yield, grape quality and individual anthocyanin composition in Vitis vinifera L. cv.'Tempranillo'. Agricultural Water Management 98(7): 1171-1179.

Santesteban, L. G., C. Miranda and J. B. Royo (2011b). Suitability of pre-dawn and stem water potential as indicators of vineyard water status in cv. Tempranillo. Australian Journal of Grape and Wine Research 17(1): 43-51.

Santesteban, L. G., C. Miranda, J. Urrestarazu, M. Loidi and J. B. Royo (2017). Severe trimming and enhanced competition of laterals as a tool to delay ripening in Tempranillo vineyards under semiarid conditions. OENO One 51(2): 191-203.

Santos, J. A., A. C. Malheiro, M. K. Karremann and J. G. Pinto (2011). Statistical modelling of grapevine yield in the Port Wine region under present and future climate conditions. International Journal of Biometeorology 55(2): 119-131.

Santos, T. P., C. M. Lopes, M. L. Rodrigues, C. R. d. Souza, J. M. Ricardo-da-Silva, J. P. Maroco, J. S. Pereira and M. M. Chaves (2005). Effects of partial root-zone drying irrigation on cluster microclimate and fruit composition of field-grown Castelao grapevines. Vitis 44(3): 117-125.

Savoi, S., D. C. Wong, P. Arapitsas, M. Miculan, B. Bucchetti, E. Peterlunger, A. Fait, F. Mattivi and S. D. Castellarin (2016). Transcriptome and metabolite profiling reveals that prolonged drought modulates the phenylpropanoid and terpenoid pathway in white grapes (Vitis vinifera L.). BMC Plant Biology 16(1): 67.

Schaefer, K., H. Lantuit, V. E. Romanovsky, E. A. Schuur and R. Witt (2014). The impact of the permafrost carbon feedback on global climate. Environmental Research Letters 9(8): 085003.

Schneider, C. A., W. S. Rasband and K. W. Eliceiri (2012). NIH Image to ImageJ: 25 years of image analysis. Nat Meth 9(7): 671-675.

Schreiner, R. P. (2003). Mycorrhizal Colonization of Grapevine Rootstocks under Field Conditions. American Journal of Enology and Viticulture 54(3): 143-149. 
Schultz, H. (1995). Grape canopy structure, light microclimate and photosynthesis. I. A two-dimensional model of the spatial distribution of surface area densities and leaf ages in two canopy systems. VITIS-GEILWEILERHOF- 34: 211-216.

Schultz, H. (2000). Climate change and viticulture: A European perspective on climatology, carbon dioxide and UV-B effects. Australian Journal of Grape and Wine Research 6(1): 2-12.

Schultz, H. R. (2003). Differences in hydraulic architecture account for nearisohydric and anisohydric behaviour of two field-grown Vitis vinifera L. cultivars during drought. Plant, Cell \& Environment 26(8): 1393-1405.

Schultz, H. R. (2016). Global Climate Change, Sustainability, and Some Challenges for Grape and Wine Production. Journal of Wine Economics 11(1): 181-200.

Schultz, H. R. and G. V. Jones (2010). Climate induced historic and future changes in viticulture. Journal of Wine Research 21(2-3): 137-145.

Schultz, H. R. and M. Stoll (2010). Some critical issues in environmental physiology of grapevines: future challenges and current limitations. Australian Journal of Grape and Wine Research 16: 4-24.

Seem, R., R. Magarey, J. Zack and J. Russo (2000). Estimating disease risk at the whole plant level with General Circulation Models. Environmental Pollution 108(3): 389-395.

Sepulveda, G. and W. M. Kliewer (1986). Effect of high-temperature on grapevines (Vitis Vinifera L.).2 Distribution of soluble sugars. American Journal of Enology and Viticulture 37(1): 20-25.

Sepúlveda, G., W. M. Kliewer and K. Ryugo (1986). Effect of high temperature on grapevines (Vitis vinifera L.). I. Translocation of 14C-photosynthates. American Journal of Enology and Viticulture 37(1): 13-19.

Serra, I., A. Strever, P. A. Myburgh and A. Deloire (2014). Review: the interaction between rootstocks and cultivars (Vitis vinifera L.) to enhance drought tolerance in grapevine. Australian Journal of Grape and Wine Research 20(1): 1-14.

Sheffield, J. and E. F. Wood (2008). Global trends and variability in soil moisture and drought characteristics, 1950-2000, from observation-driven simulations of the terrestrial hydrologic cycle. Journal of Climate 21(3): 432-458. 
Shellie, K. C. and B. A. King (2013a). Kaolin Particle Film and Water Deficit Influence Malbec Leaf and Berry Temperature, Pigments, and Photosynthesis. American Journal of Enology and Viticulture 64(2): 223-230.

Shellie, K. C. and B. A. King (2013b). Kaolin Particle Film and Water Deficit Influence Red Winegrape Color under High Solar Radiation in an Arid Climate. American Journal of Enology and Viticulture 64(2): 214-222.

Smart, R. and H. Barrs (1973). The effect of environment and irrigation interval on leaf water potential of four horticultural species. Agricultural Meteorology 12: 337-346.

Smart, R., J. K. Dick, I. M. Gravett and B. Fisher (1990). Canopy management to improve grape yield and wine quality. Principles and practices. S. Afr. J. Enol. Vitic 11(1): 317.

Smart, R. and M. Robinson (1991). Sunlight into wine: a handbook for winegrape canopy management. Adelaide,S.A., Australia, Winetitles.

Smart, R. E. (1973). Sunlight Interception by Vineyards. American Journal of Enology and Viticulture 24(4): 141-147.

Smart, R. E. (1985). Principles of Grapevine Canopy Microclimate Manipulation with Implications for Yield and Quality. A Review. American Journal of Enology and Viticulture 36(3): 230-239.

Smart, R. E. (1988). Shoot Spacing and Canopy Light Microclimate. American Journal of Enology and Viticulture 39(4): 325-333.

Snyder, R., R. Moratiel, Z. Song, A. Swelam, I. Jomaa and T. Shapland (2011). Evapotranspiration response to climate change. Acta horticulturae 922: 91-98.

Soar, C. J. and B. R. Loveys (2007). The effect of changing patterns in soil-moisture availability on grapevine root distribution, and viticultural implications for converting fullcover irrigation into a point-source irrigation system. Australian Journal of Grape and Wine Research 13(1): 2-13.

Song, J., K. C. Shellie, H. Wang and M. C. Qian (2012). Influence of deficit irrigation and kaolin particle film on grape composition and volatile compounds in Merlot grape (Vitis vinifera L.). Food Chemistry 134(2): 841-850. 
Spayd, S. E., J. M. Tarara, D. L. Mee and J. C. Ferguson (2002). Separation of sunlight and temperature effects on the composition of Vitis vinifera cv. Merlot berries. American Journal of Enology and Viticulture 53(3): 171-182.

Sperry, J. S., V. Stiller and U. G. Hacke (2003). Xylem Hydraulics and the Soil-PlantAtmosphere Continuum. Agronomy Journal 95(6): 1362-1370.

Steduto, P. and R. Albrizio (2005). Resource use efficiency of field-grown sunflower, sorghum, wheat and chickpea: II. Water use efficiency and comparison with radiation use efficiency. Agricultural and Forest Meteorology 130(3): 269-281.

Steduto, P., T. C. Hsiao and E. Fereres (2007). On the conservative behavior of biomass water productivity. Irrigation Science 25(3): 189-207.

Stoll, M., M. Lafontaine and H. R. Schultz (2010). Possibilities to reduce the velocity of berry maturation through various leaf area to fruit ratio modifications in Vitis vinifera L. Riesling. Progres Agricole et Viticole 127(3): 68-71.

Swift, R. S. (2001). Sequestration of carbon by soil. Soil Science 166(11): 858-871.

Tarara, J. M., J. C. Ferguson, G. A. Hoheisel and J. E. Perez Peña (2005). Asymmetrical canopy architecture due to prevailing wind direction and row orientation creates an imbalance in irradiance at the fruiting zone of grapevines. Agricultural and Forest Meteorology 135(1-4): 144-155.

Terrier, N., D. Glissant, J. Grimplet, F. Barrieu, P. Abbal, C. Couture, A. Ageorges, R. Atanassova, C. Leon and J. P. Renaudin (2005). Isogene specific oligo arrays reveal multifaceted changes in gene expression during grape berry (Vitis vinifera L.) development. Planta 222.

Tomás, M., H. Medrano, J. M. Escalona, S. Martorell, A. Pou, M. Ribas-Carbó and J. Flexas (2014). Variability of water use efficiency in grapevines. Environmental and Experimental Botany 103(Supplement C): 148-157.

Tonietto, J. and A. Carbonneau (2004). A multicriteria climatic classification system for grape-growing regions worldwide. Agricultural and Forest Meteorology 124(1): 81-97.

Torres, N., N. Goicoechea and M. Carmen Antolín (2017). Influence of irrigation strategy and mycorrhizal inoculation on fruit quality in different clones of Tempranillo grown under elevated temperatures. Agricultural Water Management.

Tortosa, I., J. M. Escalona, J. Bota, M. Tomás, E. Hernández, E. G. Escudero and H. Medrano (2016). Exploring the genetic variability in water use efficiency: Evaluation of 
inter and intra cultivar genetic diversity in grapevines. Plant Science 251(Supplement C): $35-43$.

Trentacoste, E. R., D. J. Connor and M. Gómez-del-Campo (2015). Effect of row spacing on vegetative structure, fruit characteristics and oil productivity of $\mathrm{N}-\mathrm{S}$ and $\mathrm{E}-\mathrm{W}$ oriented olive hedgerows. Scientia Horticulturae 193: 240-248.

Trigo-Córdoba, E., Y. Bouzas-Cid, I. Orriols-Fernández, E. Díaz-Losada and J. M. MirásAvalos (2015). Influence of cover crop treatments on the performance of a vineyard in a humid region. Spanish Journal of Agricultural Research 13(4): 0907.

Uriarte, D., D. S. Intrigliolo, L. A. Mancha, J. Picón-Toro, E. Valdés and M. H. Prieto (2014). Interactive Effects of Irrigation and Crop Level on Tempranillo Vines in a Semi-Arid Climate. American Journal of Enology and Viticulture.

Van Leeuwen, C., H. R. Schultz, I. G. de Cortazar-Atauri, E. Duchêne, N. Ollat, P. Pieri, B. Bois, J.-P. Goutouly, H. Quénol and J.-M. Touzard (2013). Why climate change will not dramatically decrease viticultural suitability in main wine-producing areas by 2050 . Proceedings of the National Academy of Sciences 110(33): E3051-E3052.

Vanden Heuvel, J. E., Proctor, J. T. A., Sullivan, J. A. and Fisher, K. H. (2004). Influence of training/trellising system and rootstock selection on productivity and fruit composition of Chardonnay and Cabernet franc grapevines in Ontario, Canada. American Journal of Enology and Viticulture 55(3): 253-264.

Vergnes, A. (1981). Observations on some effects of late pruning and tip pruning on coulure in the grapevine. Progres Agricole et Viticole 98(11): 506-510.

Vicente, A. (2017). Efectos del riego moderado y el aclareo de racimos en el comportamiento fisiológico, agronómico y cualitativo de Vitis vinífera L. cv. Verdejo. PhD Thesis, Valladolid University, Spain.

Vilanova, M., M. E. Valdés, D. Uriarte, J. Yuste, A. Vicente, D. Pérez and J. R. Castel (2014). On the aromatic composition of three white grapevine varieties (Doña Blanca, Muscat of Alexandria, Verdejo) as affected by irrigation in Spain. Proceedings of X Congres International des Terroirs vitivinicoles, Tokaj 2: 227-233.

Vitrac, X., F. Larronde, S. Krisa, A. Decendit, G. Deffieux and J.-M. Mérillon (1999). Sugar sensing and $\mathrm{Ca} 2+-$ calmodulin requirement in Vitis vinifera cells producing anthocyanins. Phytochemistry 53(6): 659-665. 
Vivin, P., É. Lebon, Z. Dai, É. Duchêne, E. Marguerit, I. García de Cortázar-Atauri, J. Zhu, T. Simonneau, C. van Leeuwen, S. Delrot and N. Ollat (2017). Combining ecophysiological models and genetic analysis: a promising way to dissect complex adaptive traits in grapevine. OENO One 51(2): 181-189.

Walker, B., C. S. Holling, S. Carpenter and A. Kinzig (2004). Resilience, adaptability and transformability in social-ecological systems. Ecology and Society $\mathbf{9 ( 2 ) . ~}$

Wample, R. and R. Smithyman (2002). Regulated deficit irrigation as a water management strategy in Vitis vinifera production. Deficit irrigation practices.

Webb, L., P. Clingeleffer and S. Tyerman (2011). The genetic envelope of winegrape vines: potential for adaptation to future climate challenges. Crop Adaptation to Climate Change S. Yadav, J. Hatfield and R. Redden.

Webb, L., P. Whetton and E. Barlow (2007a). Climate change impacts on Australian viticulture.

Webb, L. B., P. H. Whetton and E. W. R. Barlow (2007b). Modelled impact of future climate change on the phenology of winegrapes in Australia. Australian Journal of Grape and Wine Research 13(3): 165-175.

Webb, L. B., P. H. Whetton, J. Bhend, R. Darbyshire, P. R. Briggs and E. W. R. Barlow (2012). Earlier wine-grape ripening driven by climatic warming and drying and management practices. Nature Climate Change 2(4): 259-264.

Williams, L. and F. Araujo (2002). Correlations among predawn leaf, midday leaf, and midday stem water potential and their correlations with other measures of soil and plant water status in Vitis vinifera. Journal of the American Society for Horticultural Science 127(3): 448-454.

Williams, L. E. (2012). Effects of applied water amounts at various fractions of evapotranspiration (ETc) on leaf gas exchange of Thompson Seedless grapevines. Australian Journal of Grape and Wine Research 18(1): 100-108.

Williams, L. E. (2014). Effect of applied water amounts at various fractions of evapotranspiration on productivity and water footprint of Chardonnay grapevines. American Journal of Enology and Viticulture: ajev. 2014.12105.

Williams, L. E. and J. E. Ayars (2005). Grapevine water use and the crop coefficient are linear functions of the shaded area measured beneath the canopy. Agricultural and Forest Meteorology 132(3-4): 201-211. 
Williams, L. E. and P. Baeza (2007). Relationships among Ambient Temperature and Vapor Pressure Deficit and Leaf and Stem Water Potentials of Fully Irrigated, Field-Grown Grapevines. American Journal of Enology and Viticulture 58(2): 173-181.

Williams, L. E., D. W. Grimes and C. J. Phene (2010). The effects of applied water at various fractions of measured evapotranspiration on water relations and vegetative growth of Thompson Seedless grapevines. Irrigation Science 28(3): 221-232.

Williams, L. E. and M. A. Matthews (1990). Grapevine. Stewart, B.A. and Nielsen, D.R., eds. Irrigation of agricultural crops. American Society of Agronomy: Madison, WI, USA $\mathbf{3 0}$ 1019-1055.

Williams, L. E. and R. J. Smith (1991). The Effect of Rootstock on the Partitioning of Dry Weight, Nitrogen and Potassium, and Root Distribution of Cabernet Sauvignon Grapevines. American Journal of Enology and Viticulture 42(2): 118-122.

Williams, L. E. and T. J. Trout (2005). Relationships among Vine- and Soil-Based Measures of Water Status in a Thompson Seedless Vineyard in Response to High-Frequency Drip Irrigation. American Journal of Enology and Viticulture 56(4): 357-366.

Wohlfahrt, Y., S. Tittmann and M. Stoll (2017). Physiologial and yield performance of Vitis vinifera L. cvs. (Riesling and Cabernet Sauvignon) under free air carbon dioxide enrichment (FACE). Full manuscripts of 20th International Meeting Giesco, November 5th10th 2017, Mendoza, Argentina: 25-30.

Wolfe, D. W., M. D. Schwartz, A. N. Lakso, Y. Otsuki, R. M. Pool and N. J. Shaulis (2005). Climate change and shifts in spring phenology of three horticultural woody perennials in northeastern USA. International Journal of Biometeorology 49(5): 303-309.

$\mathrm{Xu}, \mathrm{L} . \mathrm{-K}$. and T. C. Hsiao (2004). Predicted versus measured photosynthetic wateruse efficiency of crop stands under dynamically changing field environments. Journal of Experimental Botany 55(407): 2395-2411.

Xu, Y., T. Castel, Y. Richard, C. Cuccia and B. Bois (2012). Burgundy regional climate change and its potential impact on grapevines. Climate Dynamics 39(7-8): 1613-1626.

Yamane, T., S. T. Jeong, N. Goto-Yamamoto, Y. Koshita and S. Kobayashi (2006). Effects of temperature on anthocyanin biosynthesis in grape berry skins. American Journal of Enology and Viticulture 57(1): 54-59.

Yan, W., M. S. Kang, B. Ma, S. Woods and P. L. Cornelius (2007). GGE biplot vs. AMMI analysis of genotype-by-environment data. Crop Science 47(2): 643-653. 
Zarco-Tejada, P. J., A. Berjón, R. López-Lozano, J. R. Miller, P. Martín, V. Cachorro, M. R. González and A. de Frutos (2005). Assessing vineyard condition with hyperspectral indices: Leaf and canopy reflectance simulation in a row-structured discontinuous canopy. Remote Sensing of Environment 99(3): 271-287.

Zarrouk, O., C. Brunetti, R. Egipto, C. Pinheiro, T. Genebra, A. Gori, C. M. Lopes, M. Tattini and M. M. Chaves (2016). Grape Ripening Is Regulated by Deficit Irrigation/Elevated Temperatures According to Cluster Position in the Canopy. Frontiers in plant science 7: 1640.

Zelleke, A. and W. M. Kliewer (1979). Influence of root temperature and rootstock on budbreak, shoot growth, and fruit composition of Cabernet Sauvignon grapevines grown under controlled conditions. American Journal of Enology and Viticulture 30(4): 312-317.

Zhang, Y., S. Kang, E. J. Ward, R. Ding, X. Zhang and R. Zheng (2011). Evapotranspiration components determined by sap flow and microlysimetry techniques of a vineyard in northwest China: Dynamics and influential factors. Agricultural Water Management 98(8): 1207-1214.

Zufferey, V., F. Murisier and H. Schultz (2000). A model analysis of the photosynthetic response of Vitis vinifera L. cvs Riesling and Chasselas leaves in the field: I. Interaction of age, light and temperature. Vitis 39(1): 19-26. 